Pacific Northwest National Laboratory

Operated by Battelle for the

U.S. Department of Energy

\section{Inventory Data Package for Hanford Assessments}

\author{
C. T. Kincaid \\ P. W. Eslinger \\ R. L. Aaberg \\ T. B. Miley \\ I. C. Nelson \\ D. L. Strenge \\ J. C. Evans, Jr.
}

June 2006

Prepared for the U.S. Department of Energy under Contract DE-AC05-76RL01830 


\title{
DISCLAIMER
}

This report was prepared as an account of work sponsored by an agency of the United States Government. Neither the United States Government nor any agency thereof, nor Battelle Memorial Institute, nor any of their employees, makes any warranty, express or implied, or assumes any legal liability or responsibility for the accuracy, completeness, or usefulness of any information, apparatus, product, or process disclosed, or represents that its use would not infringe privately owned rights. Reference herein to any specific commercial product, process, or service by trade name, trademark, manufacturer, or otherwise does not necessarily constitute or imply its endorsement, recommendation, or favoring by the United States Government or any agency thereof, or Battelle Memorial Institute. The views and opinions of authors expressed herein do not necessarily state or reflect those of the United States Government or any agency thereof.

\author{
PACIFIC NORTHWEST NATIONAL LABORATORY \\ operated by \\ BATTELLE \\ for the \\ UNITED STATES DEPARTMENT OF ENERGY \\ under Contract DE-AC05-76RL01830
}

Printed in the United States of America
Available to DOE and DOE contractors from the Office of Scientific and Technical Information,
P.O. Box 62, Oak Ridge, TN 37831-0062;
ph: (865) 576-8401
fax: (865) 576-5728
email: reports@adonis.osti.gov

\author{
Available to the public from the National Technical Information Service, \\ U.S. Department of Commerce, 5285 Port Royal Rd., Springfield, VA 22161 \\ ph: (800) 553-6847 \\ fax: (703) 605-6900 \\ email: orders@ntis.fedworld.gov \\ online ordering: http://www.ntis.gov/ordering.htm
}

This document was printed on recycled paper. 


\title{
Inventory Data Package for Hanford Assessments
}

\author{
C. T. Kincaid \\ P. W. Eslinger \\ R. L. Aaberg \\ T. B. Miley \\ I. C. Nelson \\ D. L. Strenge \\ J. C. Evans
}

June 2006

Prepared for

the U.S. Department of Energy

under Contract DE-AC05-76RL01830

Pacific Northwest National Laboratory

Richland, Washington 99352 


\section{Preface}

The 2004 Annual Status Report for the Composite Analysis of Low-Level Waste Disposal in the Central Plateau at the Hanford Site (DOE 2005a) indicated that a comprehensive update to the composite analysis (CA) was in preparation and would be submitted in 2006. The Technical Scope and Approach for the 2004 Composite Analysis of Low Level Waste Disposal at the Hanford Site (Kincaid et al. 2004) identified the requirements for that analysis and served as the basis for the data collection effort documented in this data package.

The U.S. Department of Energy (DOE) has recently decided to defer the CA update and will use the cumulative assessment currently under preparation for the environmental impact statement (EIS) being prepared for tank closure and waste management decisions as the updated CA. Submittal of the draft EIS is currently planned for FY 2008. 


\section{Summary}

The System Assessment Capability (SAC) is an environmental assessment tool, the development of which began in 1999 at the direction of the U.S. Department of Energy Richland Operations Office

(DOE-RL). This tool provides for the analysis of the movement of contaminants from waste sites at the Hanford Site into and through the vadose zone, groundwater, atmosphere, and Columbia River, to form a basis for estimating cumulative impacts (i.e., impacts from all-pathways) on hypothetical individuals who might reside onsite, on projected human populations using groundwater or Columbia River water as a function of time for the next 10,000 years, and on the ecology. The SAC tool does not address risks and impacts to intruders. This document provides an inventory of potential radioactive contaminants released (intentionally or otherwise) or disposed to ground as a function of time (past and projected) and the initial location of the release or disposal, which is essential for an analysis of alternate remedial actions.

SAC is an integrated modular system of computer codes and databases that continues to evolve as new or improved information becomes available. The codes are concerned with: annualized and total inventory of contaminants; release of contaminants from containment; movement of contaminants in the vadose zone, groundwater, atmosphere, and Columbia River; impacts on the riparian and river ecosystems; and risk to humans and other biota using groundwater from the unconfined aquifer and water from the Columbia River in the Hanford Reach and downstream. The databases relate to contaminant inventories, data supporting models of environmental pathways, and data supporting models of risk and impact.

This document presents the basis for a compilation of inventory for radioactive contaminants of interest by year for all potentially impactive waste sites on the Hanford Site for which inventory data exist in records or could be reasonably estimated. This document also includes discussions of the historical, current, and reasonably foreseeable (1944 to 2070) future radioactive waste and waste sites; the inventories of radionuclides that may have a potential for environmental impacts; a description of the method(s) for estimating inventories where records are inadequate; a description of the screening method(s) used to select those sites and contaminants that might make a substantial contribution to impacts; a listing of the remedial actions and their completion dates for waste sites; and tables showing the best estimate inventories available for Hanford assessments. 


\section{Acknowledgments}

Development of this assembly of Hanford Site inventory data and estimates has been a multiyear effort that began with the Groundwater/Vadose Zone Integration Project managed by Bechtel Hanford, Inc., continued under the Groundwater Protection Project and Groundwater Remediation Project managed by Fluor Hanford, Inc., and is finally complete under the Characterization of Systems Project managed by Pacific Northwest National Laboratory (PNNL). Throughout its development, this work has been supported by John Morse and R. Douglas Hildebrand of the Department of Energy, Richland Field Office. The Characterization of Systems Project is managed by George Last. The assembly of inventory data and estimates benefited greatly from contributions from Fluor Hanford, Inc., the Project Hanford Management Contractor, and especially from the efforts of F. Michael Coony. Contributions also came from CH2M HILL Hanford Group, Inc., the Tank Farm Contractor, and thanks go to Paul Certa, Mike Connelly, Jim Field, Tom Jones, Randy Kirkbride, and Fred Mann. Results of the Hanford Soil Inventory Model were provided by Rob Corbin, Brett Simpson, and Mike Anderson. Thanks go to our colleagues within Pacific Northwest National Laboratory (PNNL): Robert Bryce, George Last, and Mark Triplett for comments received during the years of inventory assembly. These individuals and Brian Parker (PNNL), Raymond Puigh (Fluor Federal Services), and Curtis Stroup (Fluor Hanford, Inc.) provided valuable comments during production of the final report. Thanks go to Launa Morasch and Kathy Neiderhiser who performed their usual magic by editing and composing the document for publication. PNNL is operated for the U.S. Department of Energy by Battelle under Contract DE-AC05-76RL01830. 


\section{Contents}

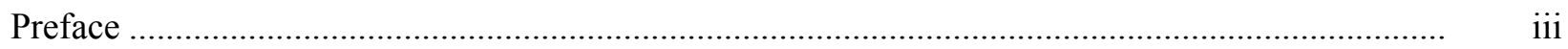

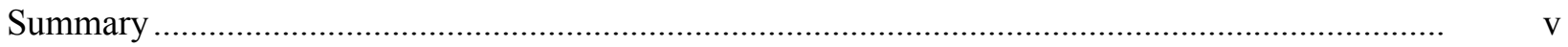

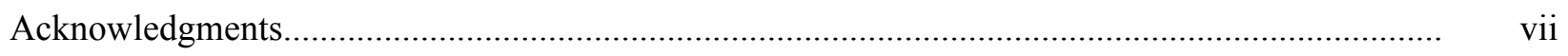

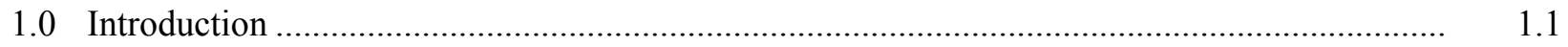

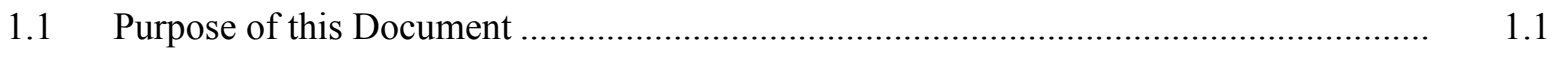

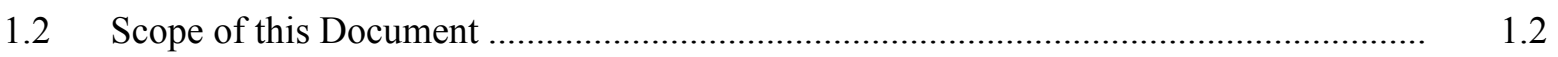

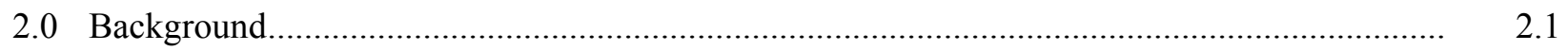

2.1 Conceptual Model of the Hanford Site Inventory …................................................. 2.1

2.2 Selection of Waste Sites and Waste Types for Analysis ............................................. 2.4

2.3 Choice of Radioactive Contaminants ......................................................................... 2.9

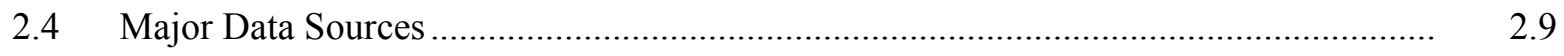

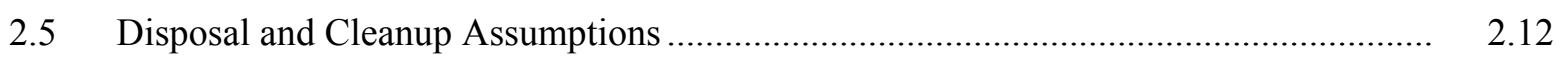

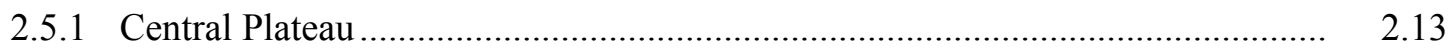

2.5.2 River Corridor .................................................................................. 2.14

2.6 Simplifying Implementation Assumptions ................................................................ 2.15

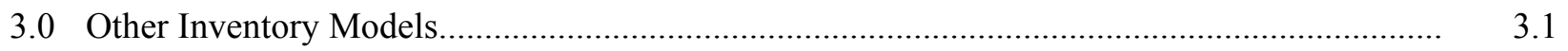

3.1 The Hanford Tank Waste Operation Simulator Model .............................................. 3.1

3.2 The Hanford Soil Inventory Model ............................................................................ 3.2

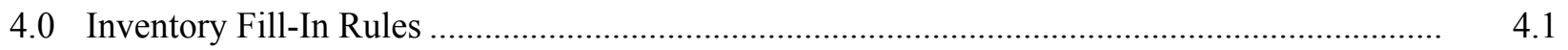

4.1 Fill-In Rules for Uranium ..................................................................................

4.1.1 Estimate Total Uranium Mass from Uranium Isotopic Composition .................. 4.1

4.1.2 Estimate Uranium Isotope Composition Given Total Uranium Mass ................ 4.1

4.1.3 Estimate Uranium Isotope Composition Given Other Uranium Isotopes ............ 4.3

4.2 Fill-In Rules for Fission Products ...........................................................................

4.2.1 Develop Fission Product Factors .................................................................. 4.3

4.2.2 Adjust Fission Product Factors for Time Delay .............................................. 4.6

$4.3 \quad$ Fill-In Rules for Activation Products ...........................................................................

4.3.1 Develop Activation Product Factors ……........................................................ $\quad 4.9$

4.3.2 Adjust Activation Product Factors for Time Delay ......................................... $\quad 4.10$

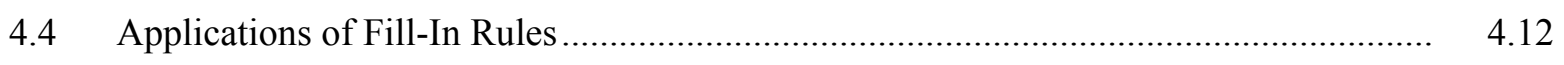

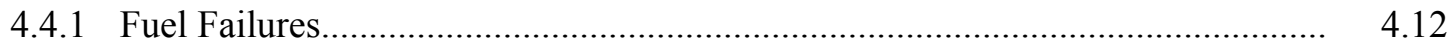

4.4.2 Uranium ...................................................................................... 4.12

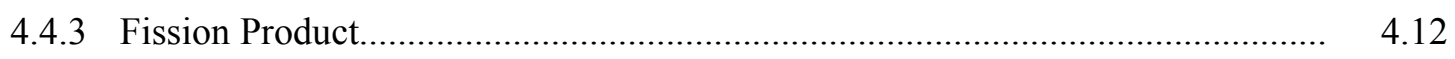

4.4.4 Activation Product ................................................................................ 4.13

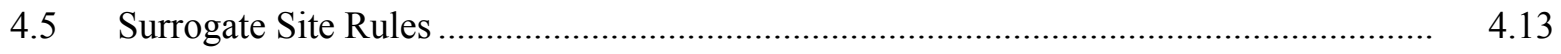




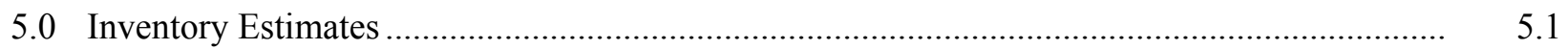

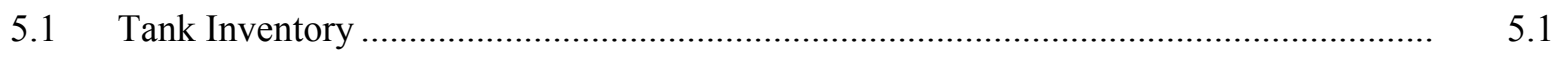

5.2 Planned and Unplanned Liquid Releases ............................................................. 5.1

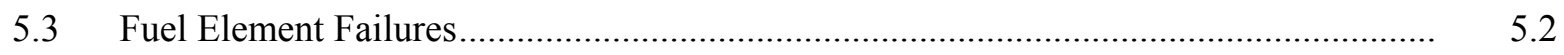

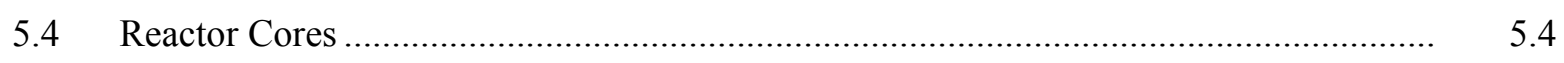

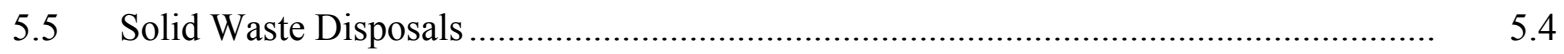

5.6 US Ecology - Commercial Low-Level Waste ............................................................ 5.6

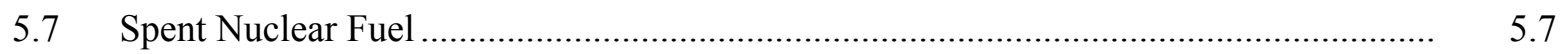

$5.8 \quad$ Special Nuclear Materials ................................................................................... 5.7

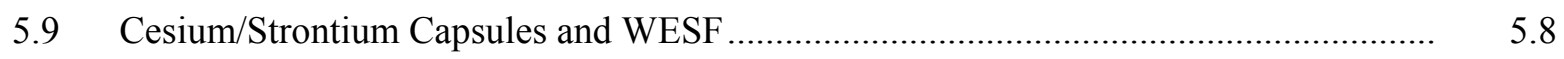

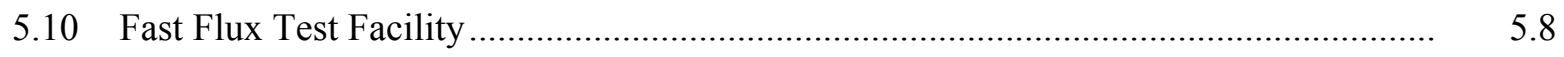

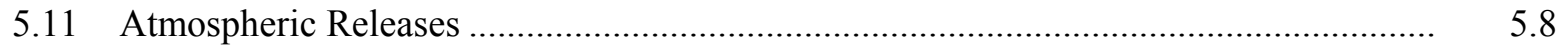

5.12 Facilities including Canyons, Tunnels, Stacks, and Filters ….................................... 5.10

5.13 Site Total Summary Including the Effect of Inventory Completion Rules ................... 5.10

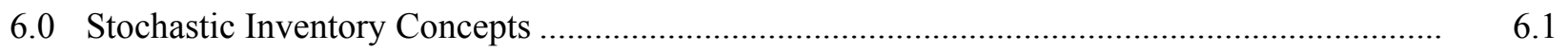

6.1 Uncertainty in Soil Inventory Model Data ................................................................. 6.1

6.2 Uncertainty in All Other Inventory Data...................................................................... 6.3

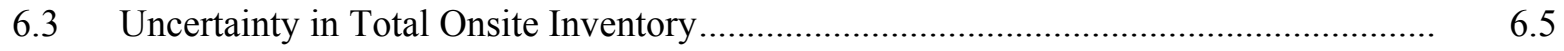

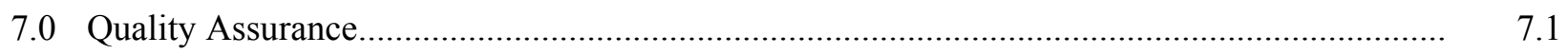

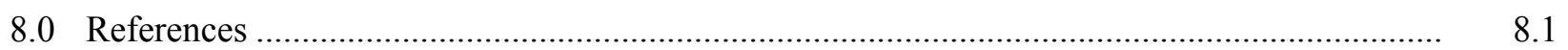

Appendix A - Remedial Actions and Completion Dates

Appendix B - Inventory Attribute Spreadsheet

Appendix C - Application of Surrogate Site Rules

Appendix D - Tritium Inventories Associated with Tritium Production

Appendix E - Best Estimate Inventory - Cumulative in 2005

Appendix F - Best Estimate Inventory - Cumulative in 2035

Appendix G - Best Estimate Inventory - Cumulative in 2070

\section{Figures}

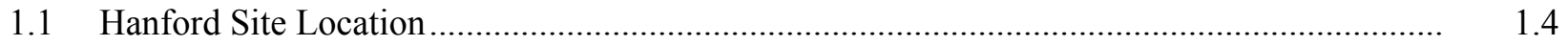

2.1 Conceptual Model of the Hanford Waste Generation and Disposition Process...................... 2.2

2.2 Avenues by which Hanford Waste Enters the Environment .................................................. 2.3

2.3 Conceptual Model of the System Assessment Capability.................................................... 2.4

6.1 Cumulative Probability Function for the Tritium Inventory Discharged to the 216-A-10 Crib in 1965 Based on the SIM Data Set...... 
6.2 Example Cumulative Probability Functions for Chlorine-36 Inventory in D Reactor Using Pre-1970 and Post-1969 Uncertainty Rules....

6.3 Example Cumulative Probability Functions for Iodine-129 Inventory in the Assumed IDF for a Single Cement Disposal Scheduled for 2011.

6.4 Example Stochastic Representation of Onsite Tritium Inventory....

6.5 Example Stochastic Representation of Onsite Technetium-99 Inventory................................ 6.7

6.6 Example Stochastic Representation of Onsite Iodine-129 Inventory .................................... 6.7

6.7 Example Stochastic Representation of Onsite Uranium-234/238 Inventory ............................ 6.8

\section{Tables}

$1.1 \quad$ Major Elements of the Inventory Assembly Process ........................................................ 1.2

2.1 Summary of Screening Rules Applied to Identify Waste Sites for Hanford Assessments .......... 2.5

2.2 Distribution of Site Classifications for the Sites Eliminated................................................... 2.6

2.3 Distribution of Site Types for Sites Eliminated .............................................................. 2.7

2.4 Distribution of Waste Types for Sites Eliminated ............................................................ 2.8

2.5 Radioactive Contaminants of Potential Concern for Hanford Assessments ............................. 2.10

3.1 Radionuclides and Chemicals Simulated by the Hanford Soil Inventory Model....................... 3.3

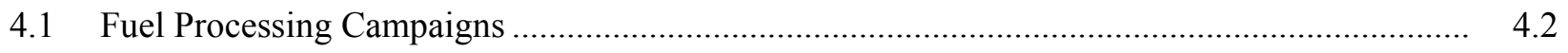

4.2 Fuel Composition Data for Six Fuel Processing Campaigns ................................................... 4.2

4.3 Fuel Composition Data Converted to Weight Percent ............................................................ 4.2

4.4 Uranium Factors by Isotope for the Representative Fuel Composition ................................... 4.3

4.5 Uranium Ratio Multiplication Factors .........................................................................

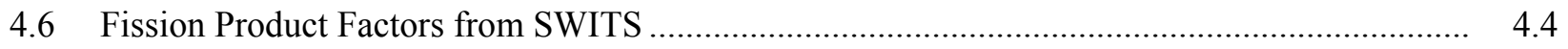

4.7 Fission Product Composition for N Reactor Fuel .............................................................

4.8 Normalized SWITS Fission Product Factors for N Reactor Fuel Isotopes ................................ 4.5

4.9 Fission Product Composition ...........................................................................................

4.10 Fission Product Composition as a Function of Time After Fuel Discharge ............................. 4.6

4.11 Representative Fuel Age ........................................................................................ 4.7

4.12 Fission Product Ratios as a Function of Years After Reactor Discharge.................................. 4.7

4.13 Activation Product Factors from SWITS ...................................................................... 4.9

4.14 Sum of Europium-154 and Europium-155 Factors for SWITS and ORIGEN2 ....................... 4.9

4.15 Final Adjusted Activation Product Factors ...................................................................... 4.10

4.16 Activation Product Composition as a Function of Time After Fuel Discharge ....................... 4.10

4.17 Activation Product Ratios as a Function of Time Since Fuel Discharge from the Reactor ........ 4.11

4.18 Inventory Introduced by Surrogate Rules ...................................................................... 4.14 
5.1 Data Files for Liquid Discharge and Unplanned Release Sites not Modeled by the Hanford SIM............................................................................................................ 5.3

5.2 Classification of Fuel Element Ruptures..................................................................... 5.4

5.3 Data Files for Solid Waste Input Data .......................................................................... 5.5

5.4 Data Files for Spent Fuel Data ................................................................................ 5.7

5.5 Reference List of Reports Including Atmospheric Releases.............................................. 5.9

5.6 Data Files for Atmospheric Release Data ........................................................................... 5.9

5.7 Reference List of Reports Including Facility and Allied Structure Inventories ....................... 5.10

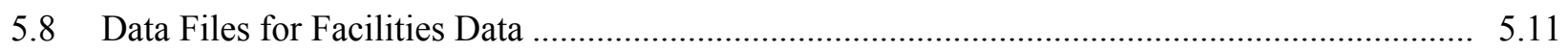

5.9 Percent of the Total Inventory in 2005 by Analyte ............................................................. 5.12

5.10 Percent of the Total Inventory in 2035 by Analyte ............................................................ 5.12

5.11 Percent of the Total Inventory in 2070 by Analyte ........................................................... 5.13

6.1 SIM Volume and Concentration Data for 200-E-25 for 1971 Liquid Releases......................... 6.1

6.2 SIM Volume and Concentration Data for 216-A-10 for 1965 Liquid Releases ........................ 6.2

6.3 Summary Statistics for Onsite Inventory for Selected Analytes.......................................... 6.6 


\subsection{Introduction}

In 1999, the U.S. Department of Energy (DOE) initiated the development of an assessment tool that would enable its users to model the movement of contaminants from waste sites at the Hanford Site through the vadose zone, groundwater, atmosphere, and Columbia River, to form the basis for estimating the composite impact to humans and the ecology. This tool was named the System Assessment Capability (SAC). It is an integrated system of computer codes and databases used to assess the impact of waste remaining on the Hanford Site. SAC simulations of future waste disposal actions and remedial actions will help decision makers and the public evaluate the relative significance of individual waste sites and the cumulative effects of contamination from Hanford.

The design of SAC resulted from extensive interactions with Hanford project staff, regulators, Tribal Nations, and other stakeholders. The approach taken in the assessment follows that advanced by regulatory agencies such as the U.S. Environmental Protection Agency (EPA) in their guidance on uncertainty analyses (Firestone et al. 1997) and ecological risk assessments (EPA 1998), and DOE in its radioactive waste management manual (DOE 1999a) and implementation guide (DOE 1999b) which support DOE Order 435.1 (DOE 1999c) on radioactive waste management. The approach taken is also consistent with the methods, characteristics, and controls associated with acceptable analyses as described by the Columbia River Comprehensive Impact Assessment (CRCIA) team (DOE 1998b).

\subsection{Purpose of this Document}

The purpose of this document is to present a description of the traceable and transparent process used to assemble an inventory for Hanford assessments. This document presents a compilation of all waste sites on the Hanford Site including historical, current, and reasonably foreseeable future waste sites (1944 to 2070) that may have a potential to affect the environment and describes the screening method used to select those sites. It also describes the screening method used to select those contaminants that are likely to make a substantial contribution to far-field and long-term impacts. The screening method did not consider impacts to intruders. The document also presents a description of the methods for estimating inventories where records are inadequate. Finally, this document presents a list of the sites and best estimate inventories available for use in future Hanford assessments. A compilation by year of the best-estimate radionuclide inventories for the waste sites and all supporting data are available from the authors.

Table 1.1 shows the major elements of the process used for assembly of the inventory from the selection of waste sites and contaminants for inclusion in the work to the assembly of the annual and cumulative inventories. The sections of the report are identified where information on each element can be found. 
Table 1.1. Major Elements of the Inventory Assembly Process

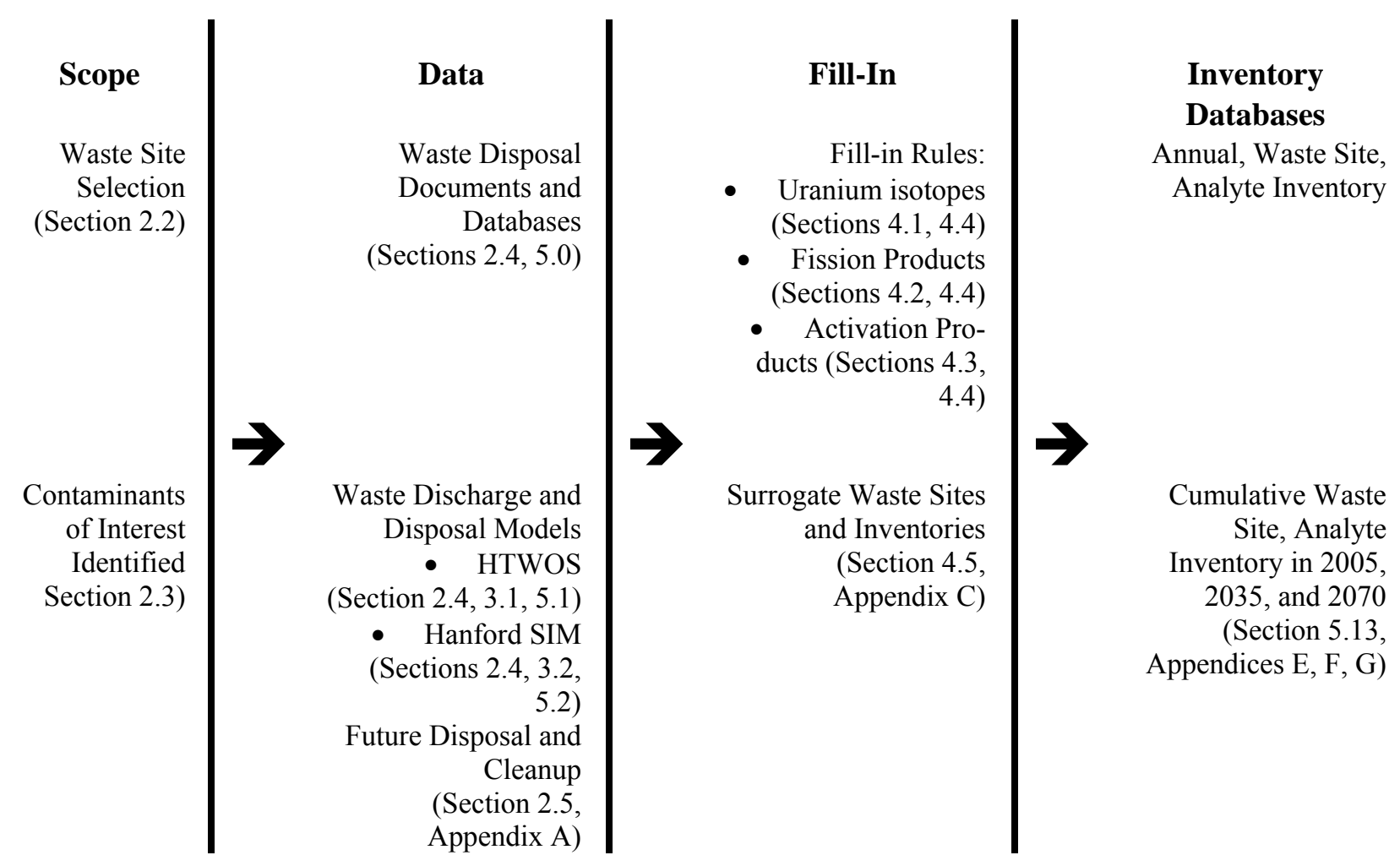

\subsection{Scope of this Document}

The scope of this inventory data package covers the radiological inventories of active and planned low-level radioactive waste (LLW) discharges and disposals and the inventories of all other sources of radioactive contamination that could interact with them (see DOE Order 435.1, Radioactive Waste Disposal). For Hanford, the inclusion of "all other sources ... that could interact" (DOE 1999c) causes all other sources of radioactive contamination remaining at Hanford to be included in Hanford assessments, (e.g., inactive prior discharges and disposals, unplanned releases including past tank leaks, residual inventories remaining in remediated structures including canyons). The unconfined aquifer underlying Hanford is continuous with groundwater flow from the Rattlesnake Hills, Cold Creek, and Dry Creek through the Central Plateau (200 Area) and to the Columbia River. There are examples of contamination from one operational area contaminating the groundwater under another, especially Central Plateau areas interacting with river corridor areas.

The location of the Hanford Site within the state of Washington, and relative to geographic features including the Rattlesnake Hills, Columbia River, and Yakima River is shown in Figure 1.1. The core zone of the Central Plateau shown in Figure 1.1 is taken from the Hanford Site End-State Vision (DOE 2005b, Figure 1.2). Groundwater contamination from past operations exists in the unconfined aquifer underlying the 100,200, and 300 Areas. Substantial plumes of mobile contaminants have migrated to the north and to the east-southeast from the Central Plateau. Co-mingling of contaminant plumes is possible between contaminant plumes with origins in the 200 Areas and those originating from the 100 and 300 Areas. Similarly, co-mingling is possible between plumes originating in the 200 West Area and 
those originating from 200 East Area waste sites. Accordingly, Hanford Site assessments can involve sources and their inventories in all operational areas of the site.

The radiological inventory is the quantity of contaminant discharged or disposed in waste sites and available for release into the environment. Where necessary to complete the portrait of the total Hanford Site inventory, this compilation includes quantities stored for future offsite shipment (e.g., spent fuel, high-level waste glass, transuranic waste destined for the Waste Isolation Pilot Plant). A thorough understanding of the inventory is key to any assessment because potential groundwater and river contamination levels are proportional to the amount of radionuclides disposed at the Hanford Site; especially those capable of migrating from discharge and disposal sites. The information needed to determine the inventory includes waste site locations, amounts or rates of discharge or disposal, concentrations of contaminants in waste or total activity in waste deposits, the change in inventory because of natural processes (e.g., decay), and the movement of inventories because of Hanford cleanup and disposal actions. The compilation of some of this information (e.g., location, cleanup schedule) resides in the Geographic and Operational Site Parameters List (GOSPL) workbook and is fully documented in the GOSPL data package (Last et al. 2006). 


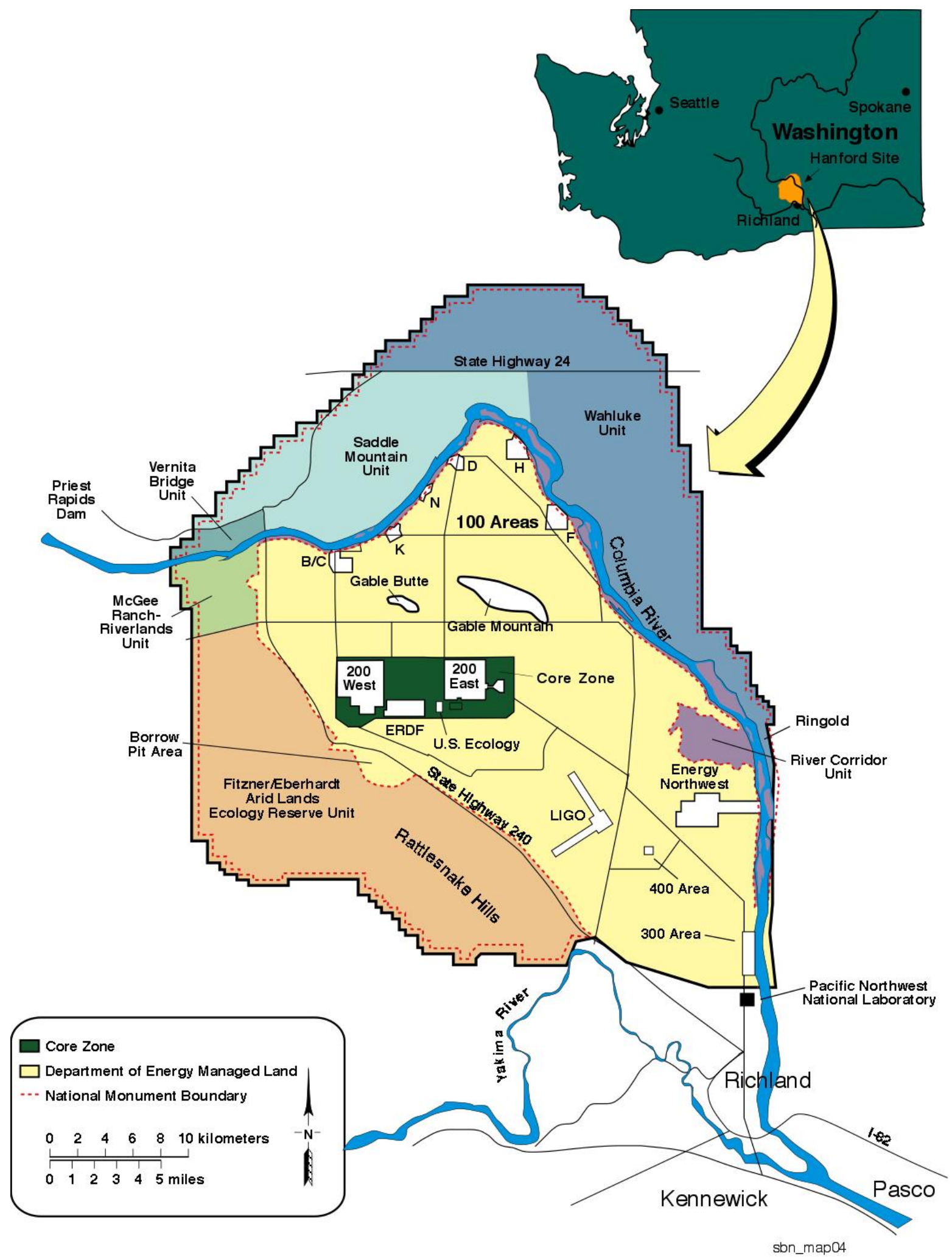

Figure 1.1. Hanford Site Location 


\subsection{Background}

The vast majority of the radioactive waste inventory at the Hanford Site was created during the production of nuclear materials for national defense during World War II and the Cold War. Research and development activities contributed, and continue to contribute, a minor amount of waste to the total. Ongoing remedial actions are resulting in the movement of waste on the Hanford Site with all remove, treat, and dispose remedial actions producing waste for disposal in the Environmental Restoration Disposal Facility (ERDF), a trench on the Central Plateau devoted to Comprehensive Environmental Response, Compensation, and Liability Act (CERCLA) waste. The recovery and treatment of tank waste will yield low-activity and low-level radioactive waste to be disposed at Hanford and vitrified high-level waste to be exported to a national repository. Discharges have occurred to the vadose zone from a variety of facilities including liquid discharges to subsurface cribs (drain fields), trenches, French drains, ditches, and ponds. Since 1944, solid waste has been disposed to unlined low-level waste burial grounds, and current disposals (including decontamination and decommissioning debris, and mixed low-level waste) occur to lined trenches. Unplanned releases directly to the vadose zone occurred when material spilled onto the land surface (e.g., containerized waste was dropped and spilled) and when liquids were lost from engineered containment systems including pipelines and buried tanks.

\subsection{Conceptual Model of the Hanford Site Inventory}

A schematic representation of Hanford Site operations and waste generation during the production operations is shown in Figure 2.1. There were four distinct steps in the production process: fuel fabrication, fuel irradiation, chemical separations, and product finishing. During the first decades at the Hanford Site, it was common to locate waste disposal sites relatively close to waste-generating facilities. This practice resulted in numerous disposal sites of varying configuration. The highly radioactive liquid waste from chemical separations was stored in large underground tanks in the 200 Areas (Agnew et al. 1997; Kupfer et al. 1997). Large volumes of solid waste (e.g., contaminated tools and protective clothing) were disposed in burial grounds, and large volumes of relatively low-level radioactive liquid waste were discharged to shallow subsurface cribs (i.e., drain fields), French drains, injection (or reverse) wells, and specific retention trenches. By 1990, all fuel fabrication, reactor operations, and chemical separations work ended and cleanup of past-practice units had begun. Low-level waste from ongoing laboratory and other waste management operations is disposed in burial grounds in the 200 West and 200 East Areas. Most liquid discharges of radioactive waste have been discontinued, an exception being liquid discharges to the State-Approved Land Disposal Site, which receives treated water from the 200 Area Effluent Treatment Facility. To determine an inventory estimate at a moment in time (e.g., now or at site closure), one needs to amend the four steps identified in Figure 2.1 to include two aspects:

1. The quantities of radionuclides and chemicals imported and exported from the Hanford Site are introduced or extracted at several points in the operation. For example, materials fed into the fuel fabrication process, chemicals fed into the reactor operation and chemical separations processes, and uranium and other special nuclear materials were exported from the Hanford Site.

2. Decisions regarding the remediation, decontamination and decommissioning, and disposal actions will impact many of the facilities and waste depicted in Figure 2.1. These cleanup actions will define the end-state configuration (i.e., both location and stability or form) of the waste remaining at the Hanford Site. 


\section{FUEL FABRICATION}
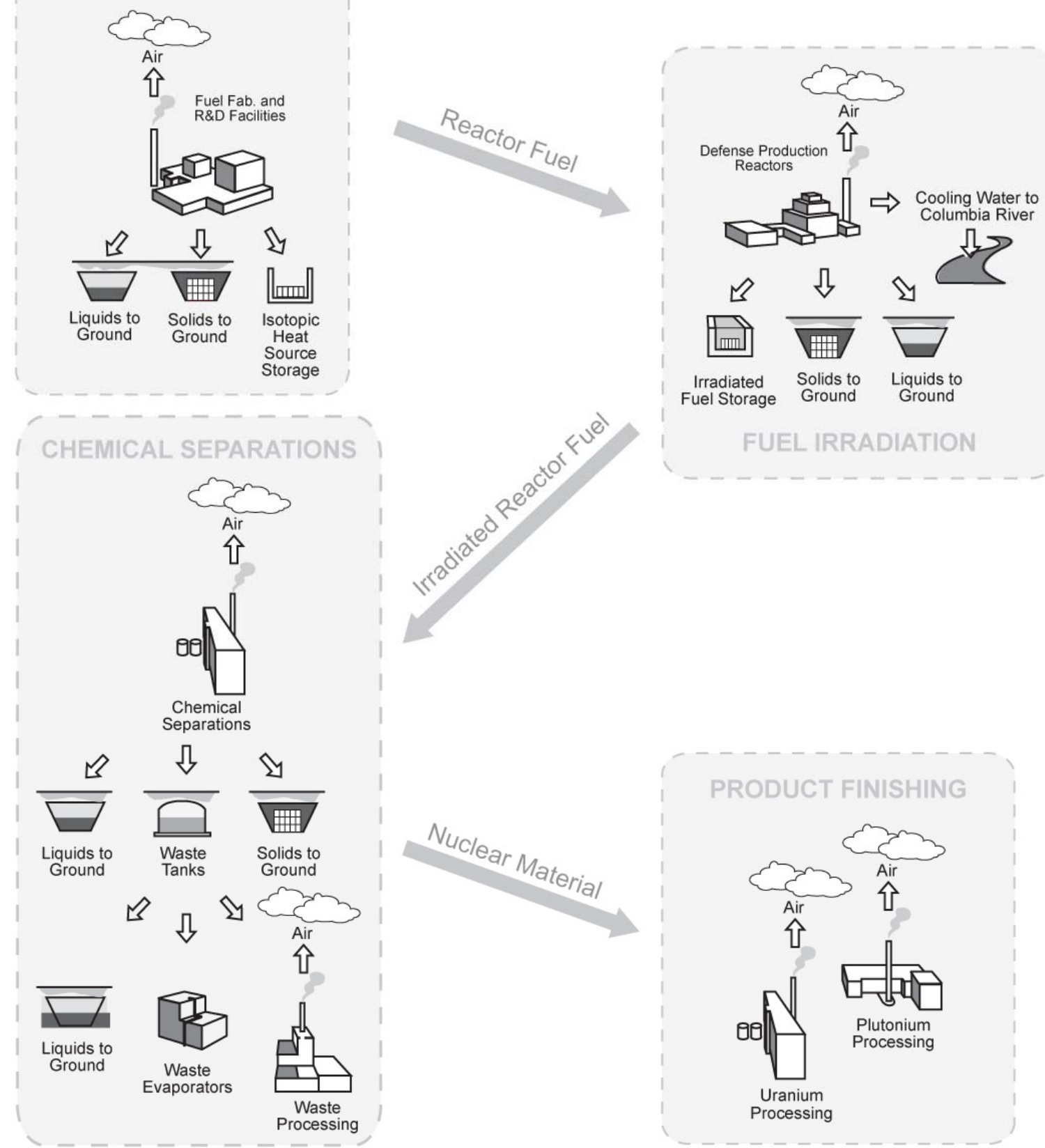

\section{FUEL IRRADIATION}

PRODUCT FINISHING

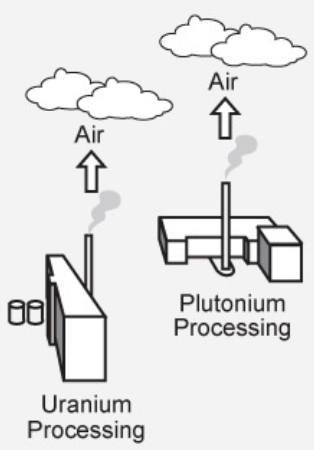

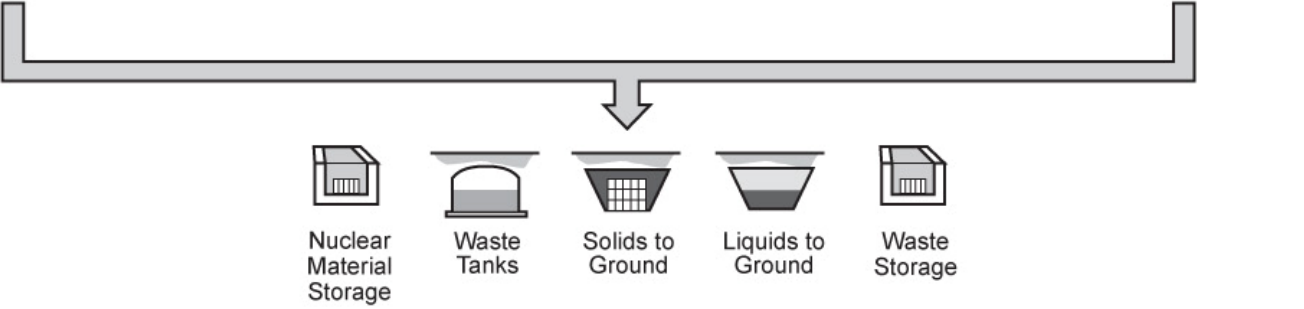

sbn06002

Figure 2.1. Conceptual Model of the Hanford Waste Generation and Disposition Process 
Avenues by which contaminants enter and migrate through the environment to reach the accessible environment are shown in Figure 2.2. In this report, materials are not considered waste until they are placed in the environment and allowed to release (e.g., solid waste) or are declared waste (e.g., spent fuel). Thus, tank waste inventories currently stored in single- and double-shell tanks in the Central Plateau are not included in this inventory until they are recovered, treated, and disposed.

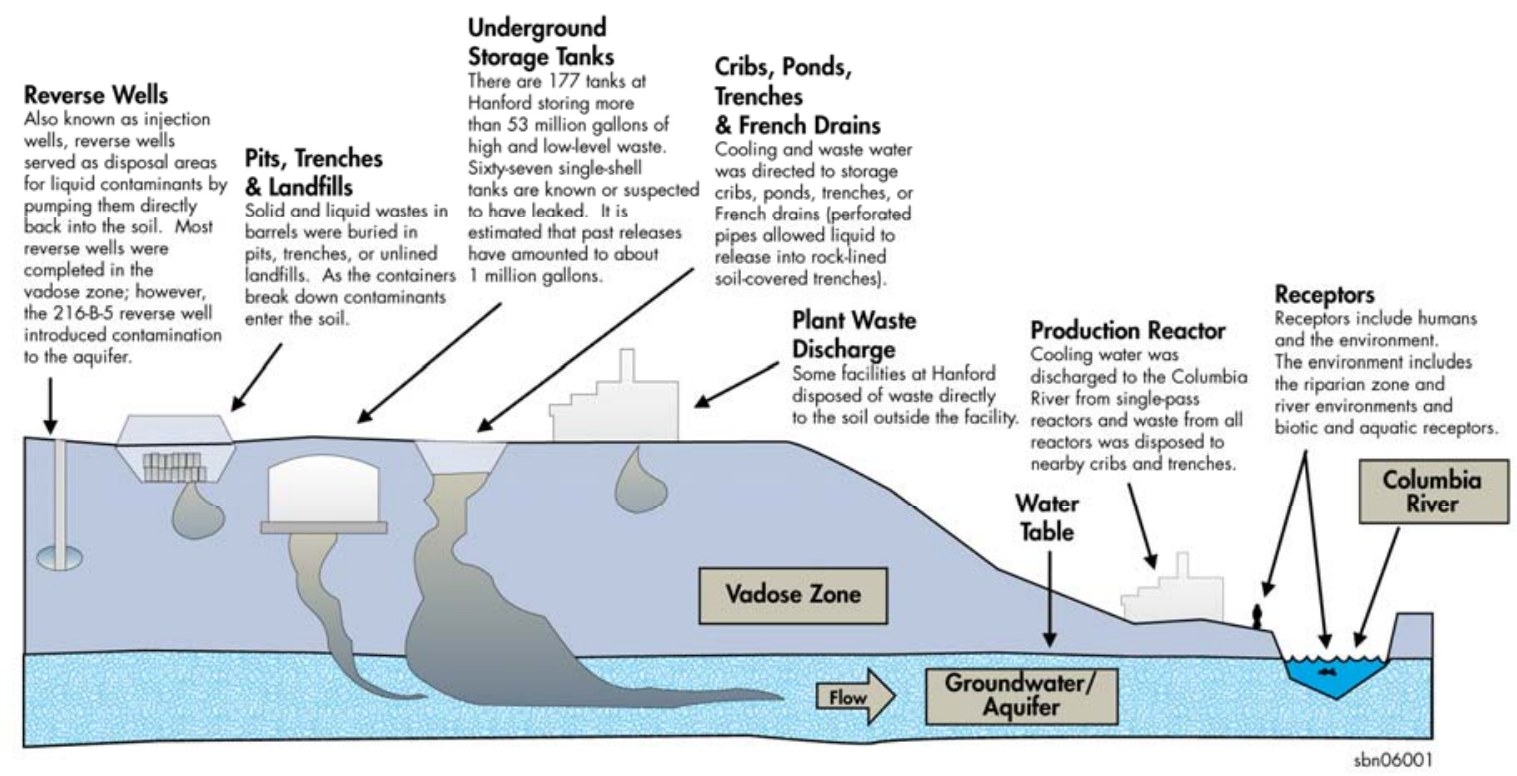

Figure 2.2. Avenues by which Hanford Waste Enters the Environment

At the Central Plateau, disposals generally fall into three classes from a contaminant migration viewpoint: those that have migrated through the vadose zone and resulted in groundwater plumes (e.g., cribs receiving tritium bearing waste from the Plutonium-Uranium Extraction [PUREX] and Reduction Oxidation [REDOX] Plants); those that have migrated deep into but not necessarily through the vadose zone (e.g., specific retention trenches like BC, BX, T, and TX); and those that have not migrated far into the vadose zone, if at all, (e.g., solid waste burial grounds). Some waste stored in underground single-shell tanks has leaked into the vadose zone and some past leaks appear to have contaminated groundwater, and at least one reverse well (i.e., 216-B-5) resulted in contamination of the unconfined aquifer.

The conceptual illustration of SAC (Figure 2.3) portrays a linear flow of information. In general, the inventory places contamination into waste sites, and the SAC tool provides for the analysis of the movement of contaminants from waste sites at the Hanford Site into and through the vadose zone, groundwater, atmosphere, and Columbia River. A soil environment is also modeled as impacted by both groundwater and atmospheric deposition. Contamination levels in the environment form a basis for estimating cumulative impacts on hypothetical future individuals and the ecology. In a few cases, the release of inventory occurs directly into the groundwater through a reverse well and into the Columbia River from the single-pass reactors. During operation of the chemical separations plant, there were direct releases into the atmosphere. The atmosphere, groundwater, Columbia River, and soil technical elements provide media-specific concentration estimates used in the risk and impact assessment. 


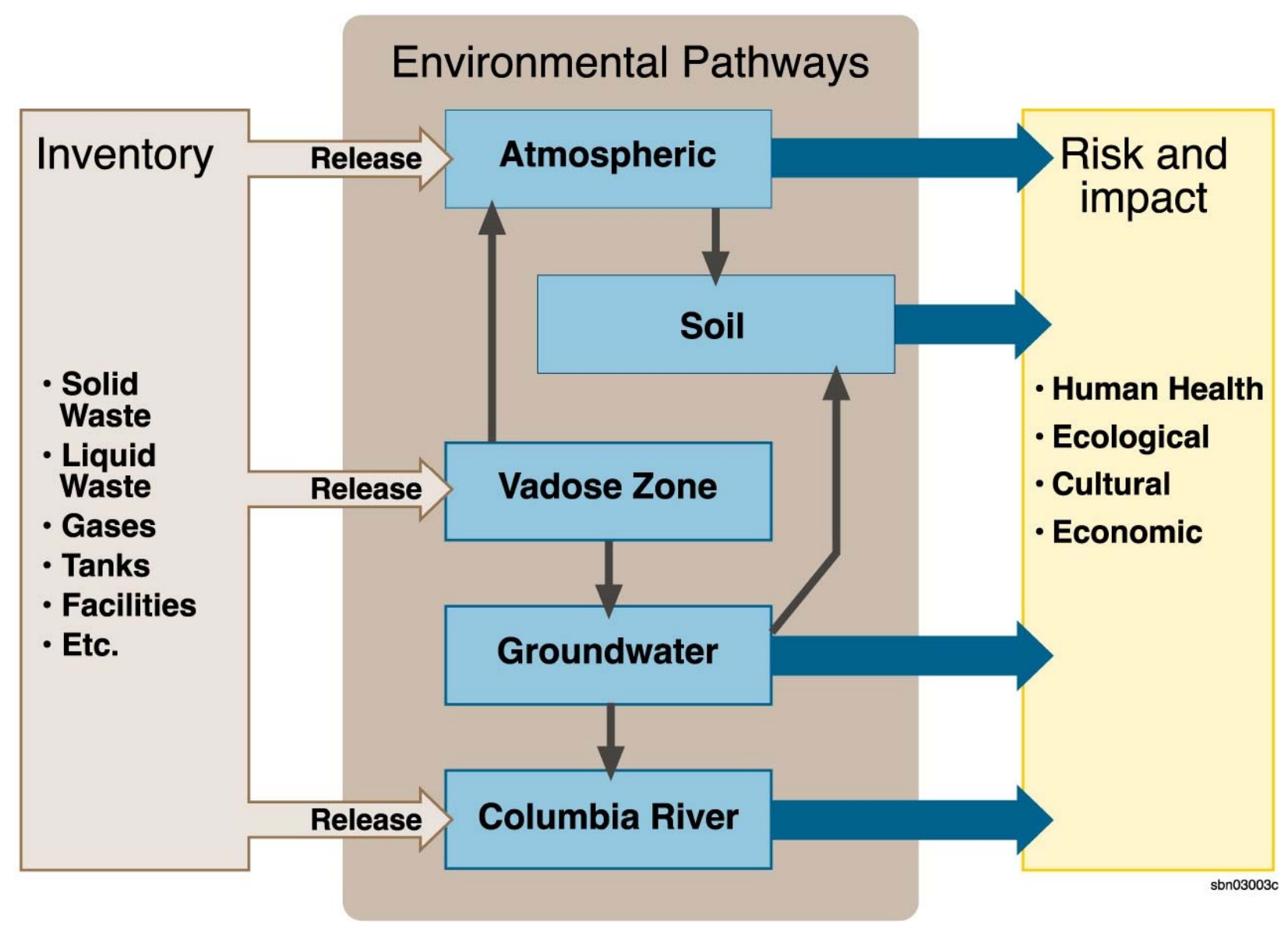

Figure 2.3. Conceptual Model of the System Assessment Capability

One of the challenges associated with performing an assessment is appropriately presenting how well the results predict what might actually occur. This is because the attributes of the site that effect transport of contaminants, the impact of contaminants on living systems, and the future conditions used in the assessment, as well as many other factors upon which the predictions depend, are not completely known or understood. SAC was developed to allow the performance of a probabilistic risk assessment so an indication of the effect of inventory uncertainty on contaminant concentrations in the environment, the ecology, and man can be examined. In general, other sources of uncertainty, such as conceptual model uncertainty are not addressed within the inventory projection (e.g., alternate concepts of chemical separations plant waste streams), but will be discussed in the interpretation of the inventory and impacts in completed analyses.

\subsection{Selection of Waste Sites and Waste Types for Analysis}

Table 2.1 summarizes the screening process used to identify 1,052 waste sites, for which inventories are to be developed if data and information are available. The screening process begins with the 2,730 sites listed in the Waste Information Data System (WIDS) in January 2003 and involves a number of screening rules or screens. Table 2.1 includes a description of the data source or screening rule applied, the number of sites deleted, and the number of sites retained after application of the screen. The original number of WIDS sites is supplemented by ten sites not named in WIDS but needed to represent 
Table 2.1. Summary of Screening Rules Applied to Identify Waste Sites for Hanford Assessments

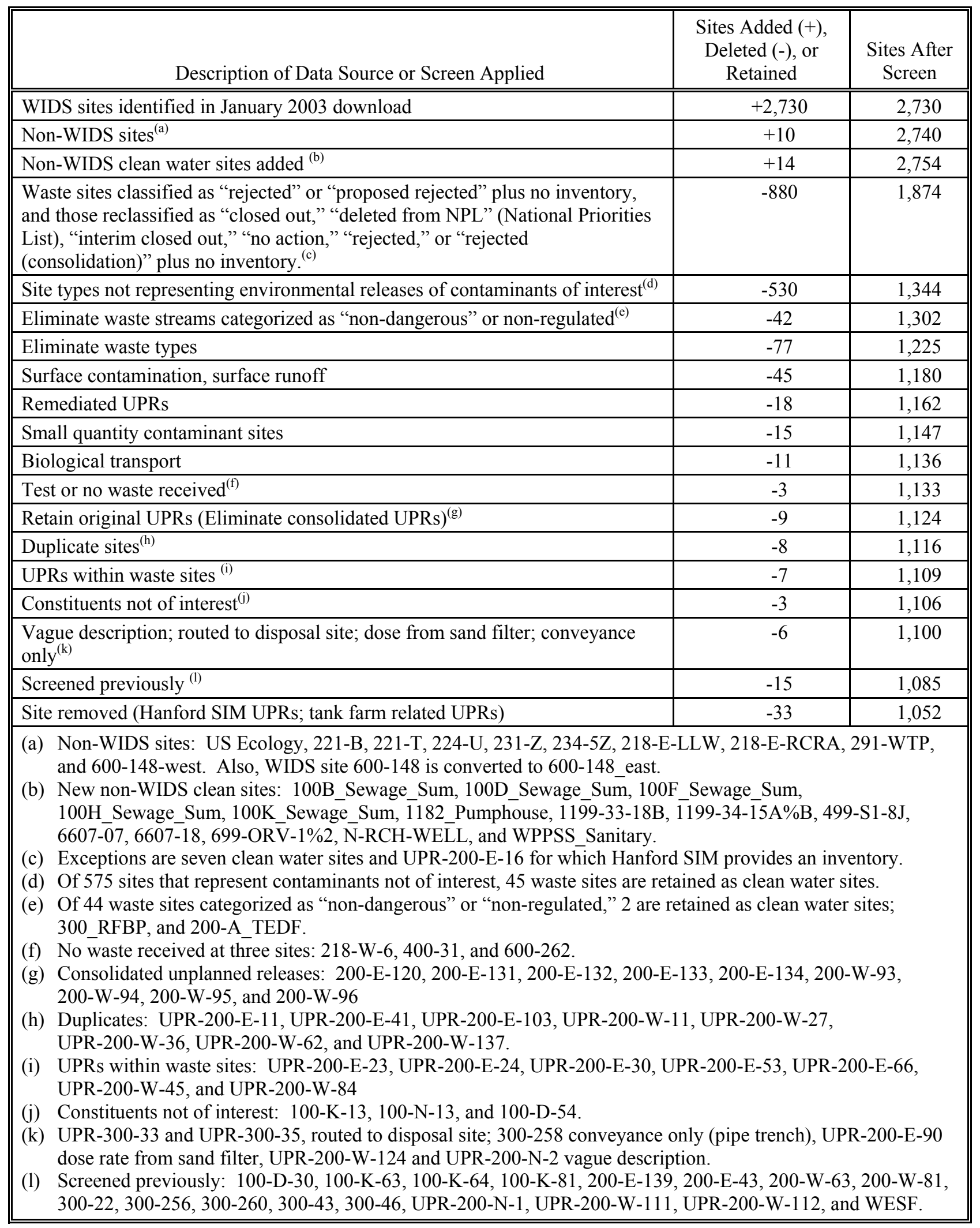


non-DOE waste and future waste disposals or accumulations of waste (for example, the commercial low-level radioactive waste disposal facility operated by US Ecology Inc., a stack release point for the future Waste Treatment Plant complex, future offsite shipments). In addition, there are 14 sites not included in WIDS that are included as clean water sites for water balance. There are 32 future waste streams (from Hanford Tank Waste Operation Simulator [HTWOS]) that are combined into 3 disposal sites and 4 products to be shipped offsite.

The series of screens that eliminate sites begins with the elimination of WIDS sites originally classified as either 'rejected' or 'rejected proposed.' 'Rejected proposed' is the label placed on a waste site in the WIDS database that is proposed for rejection. In addition, sites without an inventory that are reclassified as 'closed out,' 'deleted from NPL (National Priorities List),' 'interim closed out,' 'no action,' 'rejected,' or 'rejected consolidated' are eliminated. Table 2.2 shows the distribution of site classifications for the 880 sites eliminated by the classification criterion or screen.

Table 2.2. Distribution of Site Classifications for the Sites Eliminated

\begin{tabular}{||l|c||}
\hline \multicolumn{2}{|c|}{ Site Classification Summary } \\
\hline \hline Closed Out & 84 \\
\hline Deleted from NPL & 76 \\
\hline No Action & 12 \\
\hline Interim Closed Out & 54 \\
\hline Rejected & 571 \\
\hline Rejected (Consolidation) & 48 \\
\hline Rejected (Proposed) & 35 \\
\hline Total & $\mathbf{8 8 0}$ \\
\hline
\end{tabular}

Sites are also dropped based on their waste site type not being an environmental release point (for example, septic tanks, fabrication shops, offices, control structures, loading docks, storage pads [ $<90$ day], burn pits, coal ash pits, sanitary sewers). If releases occurred from such waste sites, they are dealt with as 'unplanned releases.' Some uncontaminated sites that are associated with the release of large amounts of water to the ground (for example, septic systems, sewage lagoons, and coal ash pits) are retained for the purpose of water balance. 'Storage pads ( $<90$ day)' is terminology used in WIDS to indicate a storage pad for Resource Conservation and Recovery Act (RCRA) identified waste that can be stored at a generator site for no longer than 90 days. Table 2.3 shows the distribution of site types for 530 sites eliminated based on site type.

Sites representing non-radioactive or non-hazardous chemical waste streams are also omitted. Forty-two sites were eliminated because the waste category associated with the site was non-hazardous and/or non-radioactive; one additional unplanned release site was eliminated because the site description indicated the spill was fuel oil. Similarly, most waste sites found to contain only hazardous nonradioactive waste are omitted on the basis of the waste type (for example, waste sites devoted to ash, asbestos, demolition and inert waste, ordinance, storm water runoff). Table 2.4 shows the distribution of waste types for 77 sites eliminated based on the type of waste disposed. 
Table 2.3. Distribution of Site Types for Sites Eliminated

\begin{tabular}{|c|c|}
\hline \multicolumn{2}{|c|}{ Site Type Summary } \\
\hline Burn pit & 30 \\
\hline Catch tank & 35 \\
\hline Coal ash pit & 3 \\
\hline Control structure & 9 \\
\hline Depression/Pit (nonspecific & 7 \\
\hline Diversion box & 71 \\
\hline Dumping area & 78 \\
\hline Electrical substation & 1 \\
\hline Evaporator & 5 \\
\hline Fabrication shop & 2 \\
\hline Foundation & 11 \\
\hline Inert/Demolition landfill & 6 \\
\hline Loading dock & 1 \\
\hline Maintenance shop & 3 \\
\hline Military compound & 3 \\
\hline Mud pit & 1 \\
\hline Neutralization tank & 20 \\
\hline Office & 1 \\
\hline Process pit & 3 \\
\hline Process sewer & 19 \\
\hline Product piping & 7 \\
\hline Pump station & 5 \\
\hline Receiver tank & 5 \\
\hline Receiving vault & 7 \\
\hline Sanitary landfill & 7 \\
\hline Sanitary sewer & 1 \\
\hline Septic tank & 59 \\
\hline Silo & 2 \\
\hline Spoils pile/Berm & 2 \\
\hline Storage pad ( $<90$ day) & 2 \\
\hline Storage tank & 75 \\
\hline Sump & 14 \\
\hline Tank farm process piping & 10 \\
\hline Valve pit & 25 \\
\hline Total & 530 \\
\hline
\end{tabular}


Table 2.4. Distribution of Waste Types for Sites Eliminated

\begin{tabular}{||l|c||}
\hline \multicolumn{2}{|c||}{ Waste Type Summary } \\
\hline \hline Asbestos (non-friable) & 1 \\
\hline Ash & 5 \\
\hline Batteries & 1 \\
\hline Construction debris & 6 \\
\hline Demolition and inert waste & 18 \\
\hline Misc. trash and debris & 15 \\
\hline Oil & 25 \\
\hline Sanitary sewage & 1 \\
\hline Vegetation & 5 \\
\hline Total & 77 \\
\hline
\end{tabular}

Finally, a review of WIDS records for specific waste sites indicates that some sites have negligible inventory. A number of WIDS sites described as surface contamination, unplanned releases that have been remediated, sites with small quantities of contaminants, duplicate sites, and sites identified but not used for waste disposal are all eliminated from consideration. Several consolidated unplanned releases that appear in WIDS are rejected in order to retain previously described releases that are better described under their original waste site designation. When applying a screen, sites that may be candidates for elimination are always compared to a list of 'waste sites with inventory data' from prior analyses and retained if listed. Ultimately, 1,052 waste sites were identified for further review and development of inventory data and estimates.

Work to define inventories has shown that sites on the list of 1,052 may not be particularly relevant to environmental releases. Efforts to develop inventories for waste sites relied on existing documentation of discharges, disposals, and unplanned releases, and on the Hanford Soil Inventory Model (Hanford SIM) for simulation of inventories for 377 liquid discharges and unplanned releases. When not included in records or Hanford SIM results, which are based on records, the history of waste sites reported in the WIDS database was reviewed to determine if there was a basis for estimating an inventory. The review identified over 100 waste sites that are accounted for in the inventory of another waste site, (e.g., an unplanned release in a solid waste burial ground), over 150 waste sites involving documented minimal releases, and others that represented duplicate event information. As of January 2006, inventory data have been assembled for a total of 690 sites for inclusion in Hanford assessments. Of these, 570 waste sites are in the Central Plateau, 97 are in the 100 Areas, 11 are in the 300 Areas, 11 are in the 600 Area, and 1 is in the 400 Area.

The list of waste sites included in future Hanford assessments will change. The WIDS file from January 2003 will be used throughout this work. However, the WIDS database is continually updated to reflect new information on existing waste sites and to incorporate newly identified waste sites. Hanford SIM simulator may identify more or different waste sites, and the HTWOS simulator may identify more or different waste streams requiring disposal. 


\subsection{Choice of Radioactive Contaminants}

The radioactive contaminants to be included in Hanford assessments were selected through the data quality objectives (DQO) process documented in (Kincaid et al. 2004). Two key considerations formed the basis for the selection process:

- Which radioactive contaminants have been observed in the environment and have the potential to impact human or ecological health?

- Which radioactive contaminants have sufficient inventory in waste sites and have the potential to impact human and/or ecological health as indicated through previous assessments?

The screening process used to select the radioactive contaminants for Hanford assessments included the following steps:

- Reviewed all groundwater monitoring data from 1990 to December 2002

- Retained all sample results above detection levels

- Retained all samples not rejected by data quality assurance checks

- Retained all radionuclides with a half-life greater than 10 years

- Identified all samples above drinking water standards

- Identified all radionuclides that have regional or Hanford Site scale distribution (spatial distribution criteria - represent more than one or two points in the aquifer)

- Identified all radionuclides that represent a current issue and not a single moment in time observation (temporal distribution criteria)

- Incorporated radionuclides that may have a future impact as indicated by performance assessments and environmental impact statement studies

The 16 radioactive contaminants selected for inclusion in Hanford assessments are listed in Table 2.5, which identifies the primary source of the selection data.

\subsection{Major Data Sources}

A single source of inventory data does not exist for the fifty plus years of Hanford operations. Records of disposals and discharges have been kept or developed from operation records; however, the content of those records has changed over time. Because disposed and discharged quantities of fission products could be related to the production of special nuclear materials, early records were secret and few efforts were made to develop or show total inventories of radionuclides with greater impact to man and the environment (e.g., technetium-99, iodine-129) until very near the end of Hanford's production mission. Our knowledge of the presence, abundance, and health implications of some radionuclides also 
Table 2.5. Radioactive Contaminants of Potential Concern for Hanford Assessments

\begin{tabular}{|c|c|c|}
\hline $\begin{array}{l}\text { Groundwater/Surface } \\
\text { Water }\end{array}$ & $\operatorname{Air}^{(a)}$ & Primary Source ${ }^{(b)}$ \\
\hline Tritium $^{(c)}$ & & Groundwater monitoring (Hartman et al. 2003) \\
\hline Carbon-14 & Carbon-14 & $\begin{array}{l}\text { Groundwater monitoring (Hartman et al. 2003); Air monitoring } \\
\text { (Poston et al. 2002) }\end{array}$ \\
\hline Chlorine-36 & & $\begin{array}{l}1998 \text { Composite Analysis (Kincaid et al. 1998), SPRD EIS } \\
\text { (DOE 1989) }\end{array}$ \\
\hline Selenium-79 & & $\begin{array}{l}\text { Immobilized Low-Activity Waste (ILAW) Performance } \\
\text { Assessment (DOE 2001) }\end{array}$ \\
\hline Strontium-90 $0^{(\mathrm{c})}$ & & Groundwater monitoring (Hartman et al. 2003) \\
\hline Technetium-99 & & Groundwater monitoring (Hartman et al. 2003) \\
\hline Iodine-129 & Iodine-129 & $\begin{array}{l}\text { Groundwater monitoring (Hartman et al. 2003); Air monitoring } \\
\text { (PNNL-13910) }\end{array}$ \\
\hline Cesium-137 & & Groundwater monitoring (Hartman et al. 2003) \\
\hline Europium-152 & & Surface water monitoring (Poston et al. 2002) \\
\hline Radium-226 $6^{(\mathrm{d})}$ & & ERDF RI/FS (DOE 1994) \\
\hline Protactinium-231 ${ }^{(\mathrm{e})}$ & & ILAW Performance Assessment (DOE 2001) \\
\hline Uranium-233 & & ILAW Performance Assessment (DOE 2001) \\
\hline Uranium-234 ${ }^{(\mathrm{c})}$ & & Groundwater monitoring (Hartman et al. 2003) \\
\hline Uranium- $235^{(\mathrm{c})}$ & & Groundwater monitoring (Hartman et al. 2003) \\
\hline Neptunium-237 & & ILAW Performance Assessment (DOE 2001) \\
\hline Uranium-238 ${ }^{(\mathrm{c})}$ & & Groundwater monitoring (Hartman et al. 2003) \\
\hline \multicolumn{3}{|c|}{$\begin{array}{l}\text { (a) Atmospheric monitoring does not identify any radionuclides at or near the standard, and, therefore, fails to } \\
\text { identify any radionuclides requiring inclusion in Hanford assessments. Carbon-14 is included as an } \\
\text { atmospheric radioactive contaminant of potential concern in Hanford assessments because it appears in the } \\
\text { surplus production reactor environmental impact statement (DOE 1989) as an atmospheric radioactive } \\
\text { contaminant of concern. Iodine- } 129 \text { is included because it has the potential to move in the vapor phase from } \\
\text { subsurface deposits to the land surface, and, thus, be available to the atmospheric transport pathway. } \\
\text { (b) Primary source that identified the radioactive contaminant as one of potential concern to be included in } \\
\text { Hanford assessments. } \\
\text { (c) Radioactive contaminants found in seeps that discharge to the Columbia River include tritium at Hanford } \\
\text { town site, strontium-90 in the } 100 \text { Area, and uranium in the } 300 \text { Area. } \\
\text { (d) Radium-226 as a progeny will be included in the calculation of uranium-234 and uranium-238 dose. } \\
\text { (e) Protactinium-231 as a progeny will be included in the calculation of uranium-235 dose. }\end{array}$} \\
\hline
\end{tabular}

changed considerably since 1944. Accordingly, early records that provided information on strontium-90, cesium-137, and specific uranium and plutonium isotopes have evolved to current records that provide data on radionuclides of greater potential health and ecological impact because of their mobility in the environment and uptake in the body, (e.g., technetium-99, iodine-129). Older records that were once believed to be sufficient for the management of waste and understanding potential health and ecological impacts are now augmented with estimates of the possible abundance of other radionuclides.

Records of solid waste disposal at the Hanford Site are maintained in the Solid Waste Information and Tracking Systems (SWITS) (Anderson 1996). Most of the information in the database on disposals 
prior to 1968 is estimated. Individual disposal records were first kept in 1968. A computer-generated report of solid waste disposal was first generated in 1971. Reports prior to 1971 were done by hand. Through the evolution of hardware, software, and data processing protocols, the recording of solid waste disposals evolved to the SWITS database that was adopted in October 1991. Today the SWITS database provides solid waste inventories for disposals from 1944 to present and includes solid waste burial grounds in all operational areas of the Hanford Site. Anderson (1996 Volume 2, Section 8) provides a complete description of the history of solid waste records development and augmentation. A database and tool for forecasting solid waste disposals is known as the Solid Waste Integrated Forecast Tool (SWIFT). Initially documented by Templeton and Dirks (1995), this tool relies on data updated annually by the generators of solid waste destined for disposal at Hanford. SWIFT provides a forecast of disposals from DOE operations that are under RCRA.

In 1979, Maxfield (1979) wrote a history, or handbook, on radioactive waste sites and unplanned releases. The document gathered information from a variety of sources on all waste sites in the Central Plateau with the exclusion of those in tank farms. Each waste site or unplanned release was described and all information concerning that site, including references to maps, illustrations, and photos, were grouped with that site. Maxfield drew upon and superseded prior reports including Anderson's (1976) report on liquid discharges through 1975. In the 1980s, waste sites were reviewed to determine their hazard ranking to define those that fell under the CERCLA program. A compilation of information on all past solid waste disposals, liquid discharges, and unplanned releases gave rise to a report by Stenner et al. (1988) and the creation of the Hanford Inactive Sites Surveillance (HISS) database. The compiled data were also provided to the WIDS database which tracks information on CERCLA and non-CERCLA waste sites. The Environmental Release Summary (ERS) database contains the historical data files of the total or cumulative radioactive inventory for inactive liquid waste sites at the Hanford Site (Diediker 1999).

Because of their relationship to past and present day estimates of tank waste, and because of their incomplete nature, the record of liquid discharges and unplanned releases at the Hanford Site are augmented by models of both tank waste and planned and unplanned liquid discharges. To augment the record of past disposals, discharges and unplanned releases with planned future disposals, simulated tank waste inventories are imported to the inventory database from the HTWOS model (Kirkbride et al. 2005). HTWOS is a model of annual waste movement from Hanford's single- and double-shell tanks to its final disposition including high-level waste glass, low-activity waste glass, bulk vitrification glass, contact-handled and remote-handled transuranic waste, tank retrieval losses, tank residuals, and all secondary waste streams (gaseous, liquid, and solid). The HTWOS model relies on the design of chemical separations, solidification, and vitrification processes incorporated into the Waste Treatment Plant and the other tank waste treatment options. The HTWOS estimates of low-activity glass, bulk vitrification glass, and solidified secondary waste streams are disposed in lined trenches at Hanford.

To augment the record of liquid discharges and unplanned releases, simulated inventories are imported to the inventory database from the Hanford SIM. The Hanford SIM is a model of annual discharge and unplanned liquid releases for the more substantial liquid waste losses to the vadose zone on Hanford's Central Plateau. The Hanford SIM uses inputs from prior reports including those by Maxfield (1979), Stenner et al. (1988), and Diediker (1999), as well as waste stream composition estimates from the Hanford Defined Waste (HDW) Model (Higley et al. 2004) to simulate planned discharges and unplanned releases. 
Specific sources for other waste that will remain at the Hanford Site and some that will be exported are reported in Section 5. For example, sources of inventory data are presented for the graphite cores of production reactors, the commercial low-level radioactive waste disposal site operated by US Ecology, the spent nuclear fuel stored pending export, the cesium-strontium capsules, and fuel-failure events associated with the operation of the single-pass production reactors.

For those waste inventories not fully assembled (i.e., many early Hanford solid waste records focus on inventories of strontium-90, cesium-137, uranium isotopes, plutonium isotopes, and waste volume), a variety of fill-in rules for fission products, activation products, and uranium isotopes were used to complete inventories when appropriate. In addition to fill-in rules, inventories for some release events can only be estimated using similarity or surrogate estimates (e.g., when a volume, date, and separations plant waste stream of origin is documented in the record, waste sites or unplanned releases with a waste stream of similar origin can be used to estimate the inventory that may have been discharged or released by the event). Fill-in rules and surrogate methods of estimating inventories are described in Section 4.

\subsection{Disposal and Cleanup Assumptions (Hanford Site Disposition Baseline)}

The suite of all remedial actions for waste sites at Hanford has been described as the Hanford Site Disposition Baseline (HSDB). The HSDB has been developed to represent the most credible end-state of the Hanford Site based on information made available by DOE and its contractors, including interim and final records of decision. Hence, the HSDB is a combination of remedial actions based on interim and final records of decision and remedial actions proposed by DOE but not yet interim or finally approved by regulatory agencies.

Remedial action assumptions are used to estimate the movement of inventory within the Hanford Site for Hanford assessments. For example, all CERCLA cleanup wastes at the Hanford Site are disposed in the ERDF trench located between 200 West and 200 East Areas on the Central Plateau. Thus, the remediated fractions of inventories in 100, 200, and 300 Area CERCLA sites move to the ERDF. A residual inventory could remain in the environment at the original site. Similar transfers of waste inventory arise in the decontamination and decommissioning of facilities, including the production reactors and canyon buildings. Where possible, assumed remedial actions will be applied to entire classes of waste or waste forms. For example, all liquid discharge sites in the river corridor will be excavated to $4.5 \mathrm{~m}$ below grade with all excavated materials transported to and disposed in the ERDF trench.

While remedial actions that result in the movement of waste from one waste site to another (e.g., ERDF) are described here, the simulated movement of the inventory occurs during model simulation. Essentially, the model of Hanford waste deposition and contaminant migration begins in 1944, and remedial actions of waste sites containing disposed or discharged waste are part of the model.

A significant step in the translation of the current setting to a stable closure of the Hanford Site is the recovery, separation, solidification, and disposal of tank waste that is now stored in single- and double-shell tanks. The inventory conceptual model provides a framework from which to estimate location, quantity, and composition of the radionuclide and chemical inventory. The conceptual model and related assumptions for tank waste are included in documentation of the HTWOS simulation included 
in this analysis (Kirkbride et al. 2005). ${ }^{1}$ The accumulation and decay correction of annual inventories yields the projection of inventory at times of interest, for example, at 2035 when the majority of waste disposal and remedial actions are complete and at 2070 when the commercial low-level radioactive waste site is assumed closed. Corresponding to the time of Hanford Site closure, the inventory model would yield a final inventory available for use in long-term Hanford risk and impact assessment.

Several of the remedies included in the HSDB do not reflect a final remedy selected by the regulatory agency. Those remedies not final will be the subject of future studies and records of decision. The baseline does include a logical suite of remedial actions based on records of decision and interim records of decision issued to date, as well as recently proposed remedial actions.

\subsubsection{Central Plateau}

Remedial actions for most waste sites on the Central Plateau of Hanford are the subject of future decisions by the Hanford Site regulatory community including the Washington State Department of Ecology (Ecology) and EPA. Accordingly, the remedial actions included in current Hanford assessments cannot be considered final until ongoing and future studies are completed and records of decision are published.

The suite of remedial actions included here are taken from the Plan for Central Plateau Closure (FHI 2004), which was approved for public release in November 2004, and unpublished information provided by DOE. ${ }^{2,3}$ The general closure approach for entire classes of waste sites are provided in Plan for Central Plateau Closure (FHI 2004); for example, for underground tanks the report indicates that:

- "Ancillary equipment will be closed in accordance with the tank system closure plans. Actions may include decontamination, flushing, grouting, removal, or isolation.

- Tanks will be isolated and void-filled.

- A barrier will be placed over the tank farm. Where possible, demolition rubble from structures within the tank farm zone will be used as fill beneath the barrier. The lateral extent of the barrier also will encompass adjacent waste sites, foundations from demolished adjacent structures, and closed wells."

In addition to the general closure approach, each of 22 closure zones are described in Appendix A of the Plan for Central Plateau Closure (FYI 2004) including a summary of the closure approach and a diagram showing the location and areal extent of surface barriers.

\footnotetext{
${ }^{1}$ Note: The movement of tank waste from tanks to disposal is not a waste-site-to-waste-site remedial action because the tank waste is initially stored in the tank and not available for release into the environment.

${ }^{2}$ Hildebrand RD (U.S. Department of Energy, Richland, Washington). July 8, 2005, e-mail to CT Kincaid (Pacific Northwest National Laboratory, Richland, Washington). Subject: FW: files on Central Plateau with attached files. Contained e-mail from RA Holten to RD Hildebrand, dated July 7, 2005. Subject: Files on Central Plateau with attached files: All_WIDS_Review_for_CPCP_update.xls, Zone Locations.xls, Zone number to MII file crosswalk.xls, and Summary of Dates.xls.

${ }^{3}$ Holten RA (DOE/RL Richland Washington). July 7, 2005, e-mail to CT Kincaid (Pacific Northwest National Laboratory, Richland, Washington). Subject: RE: ET caps and ET mono caps; Remedial action dates.
} 
The published description of the proposed remedial actions has been augmented through personal communications from DOE Richland Operations Office staff ${ }^{4,5}$ regarding the remediation proposed for individual waste sites on the Central Plateau. One change is a shift to the use of evapotranspiration (ET) caps instead of Modified RCRA Subtitle C barriers over waste sites that receive barriers. A second change is an accelerated completion schedule for remedial actions at some Central Plateau waste sites. The files indicate the date of closure for each zone (that is, MSExcel file 'Summary of Dates.xls'), and the remedy for each waste site considered on the Central Plateau (that is, MSExcel file

'All_WIDS_Review_for_CPCP_update.xls'). The remedial action and remedial action completion date are listed in Appendix A for each of the Central Plateau waste sites included in the list of 1,052 waste sites considered in this compilation of inventory for Hanford assessments.

\subsubsection{River Corridor}

Remedial actions for most waste sites on the river corridor of Hanford are the subject of interim remedial action records of decision and amendments to these actions issued by the Hanford Site regulatory community including Ecology and EPA. Accordingly, the remedial actions included in current Hanford assessments should be considered interim pending completion of remedial actions and review of the effectiveness of the remedy. In general, all waste sites in the river corridor are to be excavated and the resulting debris disposed in the ERDF trench on the Central Plateau. The production reactors are being cocooned in place for interim safe storage with surrounding buildings demolished and debris disposed in the ERDF trench. Consistent with the surplus production reactor EIS record of decision (DOE 1989), it is assumed that all of the graphite cores of the production reactors are removed from the river corridor and disposed in the 200 West Area by 2065. The final decision on remediation of the reactor cores will be the subject of future analyses.

The schedule for completion of the river corridor remedial actions as presented in the March 25, 2003, TPA Quarterly Review (BHI 2003a, 2003b) has been used to assign completion dates to waste sites. These schedule data reflect the long-range plan issued by the environmental restoration contractor (ERC) in January 2001. In addition to the schedule, ERC provided two data sets that enabled the creation of a disposition schedule: (1) a listing of sites and facilities from the ERC FY2003 Baseline Update Database ${ }^{6}$ and (2) a time series listing of ERDF disposal tonnages from operational areas. ${ }^{7}$ Appendix A shows the remedial action and remedial action completion date for each of the river corridor waste sites included in the list of 1,052 waste sites considered in this compilation of inventory for Hanford assessments.

\footnotetext{
${ }^{4}$ Hildebrand RD (U.S. Department of Energy, Richland, Washington). July 8, 2005, e-mail to CT Kincaid (Pacific Northwest National Laboratory, Richland, Washington). Subject: FW: files on Central Plateau with attached files. Contained e-mail from RA Holten to RD Hildebrand, dated July 7, 2005. Subject: Files on Central Plateau with attached files:

All_WIDS_Review_for_CPCP_update.xls, Zone Locations.xls, Zone number to MII file crosswalk.xls, and Summary of Dates.xls

${ }^{5}$ Holten RA (U.S. Department of Energy, Richland, Washington). July 7, 2005, e-mail to CT Kincaid (Pacific Northwest National Laboratory, Richland, Washington). Subject: RE: ET caps and ET mono caps; Remedial action dates.

${ }^{6}$ LaPierre, J (Bechtel Hanford Inc., Richland Washington). April 28, 2003, e-mail to CT Kincaid (Pacific Northwest National Laboratory, Richland, Washington), Subject: Site \& Facility Listing from FY03 Update Database with attached file Special List 4-28-03.

${ }^{7}$ Wintczak TM (Bechtel Hanford Inc., Richland, Washington). May 5, 2003, e-mail to CT Kincaid (Pacific Northwest National Laboratory, Richland, Washington), Subject: To tonnage.xls with attached file, To tonnage.xls.
} 


\subsection{Simplifying Implementation Assumptions}

Two key simplifying assumptions are the generation of inventory deposits on an annual basis and the aggregation of site inventories. Tank waste discharged to cribs and some unplanned releases, including tank leaks, occurred over time intervals of months, weeks, or even days. Thus, for example, a crib disposal occurring over 4 months would be treated as if the total volume of water in the disposal were discharged to the environment even in time over a 1-year interval. Annual inventories are assumed to offer sufficient temporal resolution of disposal events for the purpose of calculating long-term effects after the waste migrates in the environment. Aggregation of sites offers potential computation time and data collection savings by reducing the number of sites requiring analysis and the amount of detailed data. The response of each aggregated site is assumed to approximate the aggregate response of the sites if they were simulated individually. All disposal actions are described in the software as contaminant concentrations within a disposal volume.

The inventory model considers the waste as it comes in contact with the environment (for example, disposed to solid waste burial, contained in facilities that have been decontaminated and decommissioned, discharged to the vadose zone via liquid disposal facilities). Disposal actions occur as the waste becomes available for release to the environment, which often is not the same time as when the waste was generated because waste is often stored and treated prior to disposal. In general, material or waste stored or contained in facilities for subsequent recovery, treatment, or repackaging is not included until it is disposed. One exception is that mixed radioactive waste to be treated, packaged, and finally disposed in an Integrated Disposal Facility (IDF) is routed to the IDF when scheduled for waste storage or treatment onsite. $^{8}$ The IDF is envisioned to be a double-lined facility and it is assumed to not release contaminants until after its closure in 2035. Accordingly, waste disposal dates at IDF that pre-date 2035 are overridden by the release model. Waste in single- and double-shell tanks is not included in the inventory until tank waste is recovered, separated, vitrified, and disposed. Only the losses during waste recovery, low-activity fraction of tank waste, secondary waste streams (e.g., captured and solidified off-gas waste), and melters from the vitrification process are disposed at Hanford. However, tank leaks are entered into the inventory at the year of the leak. Once the time of site closure is reached, no further inventory will be generated, imported, or exported, and the inventory is complete.

\footnotetext{
${ }^{8}$ Note that use of an IDF in the 200 East or 200 West Area for disposal of all future DOE low-level and mixed low-level radioactive waste may or may not occur pending the record of decision for the Tank Closure and Waste Management Environmental Impact Statement.
} 


\subsection{Other Inventory Models}

Detailed models applied to estimate annual and cumulative inventories include the HTWOS and the Hanford SIM.

\subsection{The Hanford Tank Waste Operation Simulator Model}

The Tank Farm Contractor, CH2M HILL Hanford Group, Inc., has developed and applied a model designed to simulate the future processing and movement of waste currently stored in single- and double-shell tanks in the Central Plateau of the Hanford Site. It is the Hanford Tank Waste Operation Simulator, (HTWOS) (Kirkbride et al. 2005). This model begins with an inventory in each tank and simulates its future form and location by applying a series of assumptions regarding the recovery, pretreatment, and immobilization of that waste. Materials to be exported, including contact-handled and remote-handled transuranic waste and vitrified high-level waste, are assumed to be stored without the potential for future release prior to shipment from the Hanford Site. Tank waste to remain at Hanford including immobilized low-activity waste and secondary waste streams are assumed to be disposed in a new IDF located to the southwest of the PUREX Plant canyon. ${ }^{9}$

This model uses the Best Basis Inventory ${ }^{10}$ (BBI) to define the initial inventory in each tank, assumes a tank waste recovery schedule (i.e., identifies the tanks recovered each year), and assumes parameters defining the waste treatment operation (e.g., capture efficiencies in vitrification products, waste product densities and volumes, and secondary waste stream compositions). Ultimately, the HTWOS model provides a series of files showing the annual output of primary products and secondary waste streams from tank waste processing. The model also provides an estimate of the residual tank waste left in each tank following tank waste recovery, and an estimate of the liquid waste composition during tank waste recovery. This later estimate of liquid waste composition can be used to define potential losses to the vadose zone from the tank during waste recovery operations. The HTWOS model provides curie estimates for 46 radionuclides and kilogram estimates for 68 chemical elements. In addition, it provides estimates of the mass of 89 chemical species, 12 glass formers, 19 gas phase constituents, and 62 waste oxides (see Appendix C of Kirkbride et al. 2005).

The HTWOS simulation incorporated into this inventory is known as the Development Run executed on January 5, 2005, and documented in Kirkbride et al. (2005). This simulation of the HTWOS model is referred to as the Development Run because of its intended use to assist with the development of the model through the inclusion of transuranic products, bulk vitrification products, and secondary waste streams, some of which include substantial inventory of key radionuclides. Assumptions detailing the volume of tank waste products and secondary waste streams created from tank waste are summarized in Appendix A of Puigh and Wood (2005). A key assumption is the BBI of iodine-129 inventory in singleand double-shell tanks, i.e., $43.94 \mathrm{Ci}$ (acquired from TWINS on August 10, 2004). That compares to the more current BBI of October 2005 for iodine- 129 of $30.2 \mathrm{Ci}$ in tank waste, a $31 \%$ reduction.

\footnotetext{
${ }^{9}$ Use of an IDF and its location are assumed pending publication of the record of decision for the Tank Closure and Waste Management Environmental Impact Statement.

${ }^{10}$ The Best Basis Inventory is reported on the Thank Waste Information System (TWINS) web site that can be found at http://twins.pnl.gov/twins.htm. To obtain the Best Basis Inventory, go to the web site and from its main menu select "Data," then "Data Source Selection Forms," and then "Best Basis Inventory."
} 


\subsection{The Hanford Soil Inventory Model}

Under funding from the Remediation and Closure Science (RCS) Project of the Pacific Northwest National Laboratory from 2000 until 2005, and from the Tank Farm Vadose Zone Project of CH2M HILL Hanford Group, Inc. during 2005, Nuvotec has developed and applied a code to estimate the more substantial past liquid discharges and unplanned liquid releases at the Hanford Site. The model is known as the Hanford SIM, and it is in its first revision, Corbin et al. (2005). Its initial version was published in 2001 (Simpson et al. 2001). The Hanford SIM is based on process knowledge of chemical separations plants and waste transfer records from those plants to single-shell tanks, double-shell tanks and liquid discharges (e.g., to cribs, specific-retention trenches, French drains, and ponds), and unplanned releases including past tank leaks.

The Hanford SIM begins with an estimate of the inventory in spent fuel brought to the Central Plateau for processing (Wootan and Finfrock 2002). It uses estimates of waste stream compositions from the HDW Model (Higley et al. 2004) and other sources (Corbin et al. 2005). In addition to waste transfer records, several other Hanford reports are used to better define the waste composition and volume, and the timing of unplanned releases to the vadose zone environment. Among these reports are Field and Jones (2005), Diediker (1999), WHC (1990), Stenner et al (1988), and Maxfield (1979). The Hanford SIM produces a mass balanced and charged balanced estimate of the waste inventories purposely discharged or inadvertently lost to the vadose zone at 377 waste sites. The model includes inventories for 46 radionuclides and 29 chemicals.

Among the key assumptions underlying Hanford SIM inventory estimates, the Wootan and Finfrock (2002) study estimates $49.4 \mathrm{Ci}$ of iodine-129 is in processed spent fuel, and the Higley et al. (2004) study estimated $31.8 \mathrm{Ci}$ of iodine-129 remained in tank waste. This differs substantially from the BBI estimate of $43.94 \mathrm{Ci}$ of iodine-129 in tank waste included in the HTWOS model (Kirkbride et al. 2005) which came from the August 10, 2004, TWINS database.

While results of the Hanford SIM have been brought forward in this report for a short list of 16 radionuclides, estimates of a great many other analytes are available from the Hanford SIM report (Corbin et al. 2005). Table 3.1 provides the complete list of radioactive and chemical analytes reported.

The Hanford SIM is a Monte Carlo stochastic model that was executed for 25,000 realizations to achieve the converged solution reported in Corbin et al. (2005). Both the waste stream composition and the waste stream volume are treated as uncertain in the model. However, the volume of transfers are assigned a relatively narrow uncertainty range because of confidence in waste transfer reports. Annual releases to the environment are reported as 21-point distributions for inventory (in $\mathrm{Ci}$ or $\mathrm{kg}$ ), volume (in $\mathrm{ML}$ ), and concentration (in $\mu \mathrm{Ci} / \mathrm{L}$ or $\mu \mathrm{g} / \mathrm{mL}$ ). That is, values are provided corresponding to the mean, standard deviation, and the 21 percentiles $0.5 \%, 5 \%, 10 \%, 15 \%, \ldots 85 \%, 90 \%, 95 \%, 99.5 \%$. All annual data on each waste site for each analyte are reported in Appendix C of Corbin et al. (2005). 
Table 3.1. Radionuclides and Chemicals Simulated by the Hanford Soil Inventory Model

\begin{tabular}{||l|l|l|l||}
\hline \multicolumn{1}{|c|}{ Radionuclide } & \multicolumn{1}{|c|}{ Radionuclide } & \multicolumn{1}{c||}{ Chemical } & \multicolumn{1}{c||}{ Chemical } \\
\hline \hline Tritium & Radium-226 & Aluminum $(\mathrm{Al})$ & Mercury $(\mathrm{Hg})$ \\
\hline Carbon-14 & Radium-228 & Ammonia $\left(\mathrm{NH}_{3}\right)$ & Nickel $(\mathrm{Ni})$ \\
\hline Nickel-59 & Actinium-227 & Bismuth $(\mathrm{Bi})$ & Nitrate $\left(\mathrm{NO}_{3}\right)$ \\
\hline Nickel-63 & Protactinium-231 & Butanol & Nitrite $\left(\mathrm{NO}_{2}\right)$ \\
\hline Cobalt-60 & Thorium-229 & Calcium $(\mathrm{Ca})$ & $\begin{array}{l}\text { Normal paraffin } \\
\text { hydrocarbon }(\mathrm{NPH})\end{array}$ \\
\hline Selenium-79 & & & Phosphate $\left(\mathrm{PO}_{4}\right)$ \\
\hline Strontium-90 & Thorium-232 & Carbonate $\left(\mathrm{CO}_{3}\right)$ & Potassium $(\mathrm{K})$ \\
\hline Yttrium-90 & Uranium-232 & Carbon tetrachloride $\left(\mathrm{CCl}_{4}\right)$ & Silver $(\mathrm{Ag})$ \\
\hline Zirconium-93 & Uranium-233 & Chlorine $(\mathrm{Cl})$ & Silicon $(\mathrm{Si})$ \\
\hline Niobium-93m & Uranium-234 & Chromium $(\mathrm{Cr})$ & Sodium $(\mathrm{Na})$ \\
\hline Technetium-99 & Uranium-235 & Ferrocyanide $(\mathrm{Fe}(\mathrm{NC}) 6)$ & Sulfate $(\mathrm{SO} 4)$ \\
\hline Ruthenium-106 & Uranium-236 & Fluorine $(\mathrm{F})$ & Total uranium \\
\hline Cadmium-113m & Uranium-238 & Iron $(\mathrm{Fe})$ & Tributyl phosphate $(\mathrm{TBP})$ \\
\hline Antimony-125 & Neptunium-237 & Lanthanum $(\mathrm{La})$ & Zirconium $(\mathrm{Zr})$ \\
\hline Tin-126 & Plutonium-238 & Lead $(\mathrm{Pb})$ & \\
\hline Iodine-129 & Plutonium-239 & Manganese $(\mathrm{Mn})$ & \\
\hline Cesium-134 & Plutonium-240 & & \\
\hline Cesium-137 & Plutonium-241 & & \\
\hline Barium-137m & Plutonium-242 & & \\
\hline Samarium-151 & Americium-241 & & \\
\hline Europium-152 & Americium-243 & & \\
\hline Europium-154 & Curium-242 & & \\
\hline Europium-155 & Curium-243 & & \\
\hline \hline & Curium-244 & & \\
\hline
\end{tabular}




\subsection{Inventory Fill-In Rules}

Many early Hanford records focus on inventories of strontium-90, cesium-137, uranium isotopes, and plutonium isotopes as well as the waste volume. Therefore, the record information of isotope composition is incomplete for the purpose of conducting a risk analysis. A variety of fill-in rules for fission products, activation products and uranium isotopes are used to complete missing inventory values. In addition to fill-in rules, inventories for some waste sites or unplanned releases can only be estimated using similarity or surrogate estimates. For example, waste streams of similar origin can be used to estimate the inventory that may be discharged or released by an unplanned event when volume data and separations plant waste stream of origin are documented in the record. A summary of the inventory fill-in rules is provided in the following sections. These fill-in rules were provided by Fluor Hanford, Inc., and are consistent with fill-in rules applies to complete inventories in the SWITS database. More detailed information on the derivation of these rules is provided by Coony (2002).

\subsection{Fill-In Rules for Uranium}

Three related methods are used to estimate the mass or activity of uranium isotopes. These methods are applied to estimate uranium isotopic composition or total mass:

- Estimate total uranium mass given uranium isotopic composition

- Estimate isotope composition given total uranium mass

- Estimate a uranium isotope amount given other isotope amounts

Some waste streams at Hanford were a byproduct of using fuel highly enriched in uranium-233. A reasonably complete inventory is available for this special fuel type. The following general uranium rules are not applied to these special uranium-233 waste streams.

\subsubsection{Estimate Total Uranium Mass from Uranium Isotopic Composition}

When the activities of each uranium isotope are known, the total uranium mass can be calculated as follows:

$$
\mathrm{U}=\sum_{\mathrm{i}} \frac{\mathrm{A}_{\mathrm{i}}}{\mathrm{Sp}_{\mathrm{i}}}
$$

where: $\mathrm{U}=$ mass of uranium, $\mathrm{kg}$

$\mathrm{A}_{\mathrm{i}}=$ activity of each uranium isotope $\mathrm{i}, \mathrm{Ci}$

$\mathrm{Sp}_{\mathrm{i}}=$ specific activity of isotope $\mathrm{i}, \mathrm{Ci} / \mathrm{kg}$

\subsubsection{Estimate Uranium Isotope Composition Given Total Uranium Mass}

Watrous and Wootan (1997) provides detailed information on fuel processing campaigns. The time periods for several fuel processing campaigns are summarized in Table 4.1. The fuel composition (curies) for the fuel types processed in the different campaigns is provided in Table 4.2. The fuel composition data are converted to weight percent in Table 4.3 . 
Table 4.1. Fuel Processing Campaigns

\begin{tabular}{|l|c|c||}
\hline \multicolumn{1}{|c|}{ Fuel Code } & Begin & End \\
\hline \hline AL-0.71U & 1944 & 1972 \\
\hline AL-0.94U & 1958 & 1971 \\
\hline ZR-0.94U & 1963 & 1988 \\
\hline ZR-1.1U & 1966 & 1988 \\
\hline AL-0.0TH & 1965 & 1970 \\
\hline ZR-2.1U & 1968 & 1969 \\
\hline
\end{tabular}

Table 4.2. Fuel Composition Data (Ci) for Six Fuel Processing Campaigns

\begin{tabular}{||l|c|c|c|c|c|c||}
\hline \hline Fuel Code & AL-0.71U & AL-0.94U & ZR-0.94U & ZR-1.1U & AL-0.0TH & ZR-2.1U \\
\hline \hline Uranium-232 & $1.37 \mathrm{E}+00$ & $5.43 \mathrm{E}-01$ & $6.35 \mathrm{E}-01$ & $1.26 \mathrm{E}-01$ & $3.02 \mathrm{E}+03$ & $6.28 \mathrm{E}-02$ \\
\hline Uranium-233 & $4.23 \mathrm{E}-02$ & $1.47 \mathrm{E}-02$ & $6.63 \mathrm{E}-03$ & $1.51 \mathrm{E}-03$ & $1.17 \mathrm{E}+04$ & $8.79 \mathrm{E}-04$ \\
\hline Uranium-234 & $2.55 \mathrm{E}+04$ & $7.35 \mathrm{E}+03$ & $2.09 \mathrm{E}+03$ & $4.66 \mathrm{E}+02$ & $8.18 \mathrm{E}+01$ & $1.71 \mathrm{E}+02$ \\
\hline Uranium-235 & $1.09 \mathrm{E}+03$ & $2.76 \mathrm{E}+02$ & $7.57 \mathrm{E}+01$ & $2.03 \mathrm{E}+01$ & $2.53 \mathrm{E}-04$ & $7.26 \mathrm{E}+00$ \\
\hline Uranium-236 & $4.29 \mathrm{E}+02$ & $5.04 \mathrm{E}+02$ & $1.80 \mathrm{E}+02$ & $4.34 \mathrm{E}+01$ & $3.54 \mathrm{E}-05$ & $1.77 \mathrm{E}+01$ \\
\hline Uranium-238 & $2.61 \mathrm{E}+04$ & $4.99 \mathrm{E}+03$ & $1.44 \mathrm{E}+03$ & $3.20 \mathrm{E}+02$ & $2.07 \mathrm{E}-12$ & $1.19 \mathrm{E}+02$ \\
\hline
\end{tabular}

Table 4.3. Fuel Composition Data Converted to Weight Percent

\begin{tabular}{||c|c|c|c|c|c|c||}
\hline \hline Fuel Code & AL-0.71U & AL-0.94U & ZR-0.94U & ZR-1.1U & AL-0.0TH & ZR-2.1U \\
\hline \hline Uranium-232 & $0.00000 \%$ & $0.00000 \%$ & $0.00000 \%$ & $0.00000 \%$ & $0.01151 \%$ & $0.00000 \%$ \\
\hline Uranium-233 & $0.0000 \%$ & $0.0000 \%$ & $0.0000 \%$ & $0.0000 \%$ & $98.9086 \%$ & $0.0000 \%$ \\
\hline Uranium-234 & $0.0052 \%$ & $0.0079 \%$ & $0.0077 \%$ & $0.0077 \%$ & $1.0703 \%$ & $0.0077 \%$ \\
\hline Uranium-235 & $0.646 \%$ & $0.853 \%$ & $0.809 \%$ & $0.977 \%$ & $0.010 \%$ & $0.940 \%$ \\
\hline Uranium-236 & $0.0085 \%$ & $0.0520 \%$ & $0.0642 \%$ & $0.0697 \%$ & $0.0000 \%$ & $0.0765 \%$ \\
\hline Uranium-238 & $99.340 \%$ & $99.087 \%$ & $99.119 \%$ & $98.946 \%$ & $0.000 \%$ & $98.976 \%$ \\
\hline
\end{tabular}

A single reference composition is desired that represents uranium material types of normal, depleted, and enriched. The majority of the uranium in waste (greater than $90 \%$ by material type) is depleted uranium. In this composition, uranium-232 and uranium-233 are ignored as being insignificant $(<1.0 \mathrm{E}-12$ weight fraction and 1.0E-10 weight fraction, respectively). The composition of the AL-0.71U fuel is closest to the composition discussed in the Hanford Defense Waste Environmental Impact Statement (RHO 1985). Of significance is that the uranium-235 and uranium-238 weight \% are nearly identical (AL-0.71U fuel and RHO 1985). The Al-07.1U fuel composition is selected as the reference composition for the following reasons:

- The composition is similar to the RHO composition.

- The fuel represents $80 \%$ of fuel separated at Hanford.

- This fuel was separated during the period of high discharges of uranium to the ground.

Unknown isotopic values (curies) can be calculated from a known mass of uranium given the representative fuel composition. The uranium isotope factors presented in Table 4.4 provide this capability. 
Table 4.4. Uranium Factors by Isotope for the Representative Fuel Composition

\begin{tabular}{||c|c|c|c||}
\hline Isotope & $\begin{array}{c}\text { Weight } \\
(\%)^{(a)}\end{array}$ & $\begin{array}{c}\text { Specific Activity } \\
(\mathrm{Ci} / \mathrm{kg})\end{array}$ & $\begin{array}{c}\text { Uranium Isotope Factor } \\
(\mathrm{Ci} / \mathrm{kg})\end{array}$ \\
\hline \hline Uranium-232 & $(\mathrm{b})$ & $2.14 \mathrm{E}+4$ & $(\mathrm{a})$ \\
\hline Uranium-233 & $(\mathrm{b})$ & 9.68 & $3.25 \mathrm{E}-4$ \\
\hline Uranium-234 & $0.0052 \%$ & 6.25 & $1.40 \mathrm{E}-5$ \\
\hline Uranium-235 & $0.6458 \%$ & $2.16 \mathrm{E}-3$ & $5.50 \mathrm{E}-6$ \\
\hline Uranium-236 & $0.0085 \%$ & $6.47 \mathrm{E}-2$ & $3.34 \mathrm{E}-4$ \\
\hline Uranium-238 & $99.3405 \%$ & $3.36 \mathrm{E}-4$ & \\
\hline $\begin{array}{l}\text { (a) Taken from Table 4.3. } \\
\text { (b) Weight fractions and mass factors are insignificant. }\end{array}$ \\
\hline
\end{tabular}

\subsubsection{Estimate Uranium Isotope Composition Given Other Uranium Isotopes}

Unknown isotopic values (curies) can be calculated from a known value of another uranium isotope using the information provided in Table 4.4. In essence, the value of an isotope is estimated using a multiplication factor applied to another isotope. The uranium ratio multiplication factors are provided in Table 4.5. As an example application of these values, suppose that $1 \mathrm{Ci}$ of uranium-235 is known to be in a waste stream. One would then estimate there are $23.86 \mathrm{Ci}$ of uranium-238 in the same waste stream.

Table 4.5. Uranium Ratio Multiplication Factors

\begin{tabular}{||l|c|c|c|c||}
\hline \multirow{2}{*}{ Known Isotope } & \multicolumn{4}{|c||}{ Unknown Isotope $^{(\text {a) }}$} \\
\cline { 2 - 5 } & Uranium-234 & Uranium-235 & Uranium-236 & Uranium-238 \\
\hline \hline Uranium-234 & 1.00 & 0.043 & 0.017 & 1.03 \\
\hline Uranium-235 & 23.21 & 1.00 & 0.39 & 23.86 \\
\hline Uranium-236 & 59.09 & 2.55 & 1.00 & 60.73 \\
\hline Uranium-238 & 0.97 & 0.042 & 0.016 & 1.00 \\
\hline (a) Units are Ci unknown isotope/Ci known isotope. \\
\hline
\end{tabular}

\subsection{Fill-In Rules for Fission Products}

The fill-in rules for fission products start with fuel compositions reported in SWITS (Hanson et al. 1973). The fuel composition description is then expanded to include iodine-129. Finally, the fission product ratios are adjusted to account for the delay in time from reactor discharge to the time of fuel dissolution.

\subsubsection{Develop Fission Product Factors}

The fission product factors (relative abundance of difference isotopes) were obtained from SWITS (Hanson et al. 1973). The values are valid for fuel 1 year after discharge from the reactor. Given the date of the reference, the factors are likely based on simulated aluminum cladding fuel. 
A value for iodine-129 is not provided in Table 4.6. Simulated fuel compositions as a function of time for N Reactor fuel have been developed (Hedengren 1985). Selected fission product composition values were extracted for simulated Mark IV 6\% plutonium-240 fuel at 1-year reactor discharge are presented in Table 4.7.

The SWITS fission product factors in Table 4.6 were extracted for the isotopes represented in Table 4.7 and normalized to unit curie percent. These values are presented in Table 4.8. The calculations show that Mark IV fuel composition is representative of the SWITS 1-year factors.

Table 4.6. Fission Product Factors from SWITS (Ci basis)

\begin{tabular}{|l|l|l|l||}
\hline \multicolumn{1}{|c|}{ Isotope } & \multicolumn{1}{c|}{ Factor } & \multicolumn{1}{c|}{ Isotope } & \multicolumn{1}{c|}{ Factor } \\
\hline \hline Cobalt-60 & $0.000 \mathrm{E}+00$ & Tellurium-125m & $2.178 \mathrm{E}-04$ \\
\hline Selenium-79 & $4.990 \mathrm{E}-08$ & Antimony-126 & $1.094 \mathrm{E}-07$ \\
\hline Strontium-90 & $1.881 \mathrm{E}-02$ & Tin-126 & $1.105 \mathrm{E}-07$ \\
\hline Yttrium-90 & $1.881 \mathrm{E}-02$ & Antimony-126m & $1.105 \mathrm{E}-07$ \\
\hline Zirconium-93 & $6.455 \mathrm{E}-07$ & Tellurium-127 & $1.354 \mathrm{E}-03$ \\
\hline Niobium-95 & $1.053 \mathrm{E}-01$ & Tellurium-127m & $1.369 \mathrm{E}-03$ \\
\hline Zirconium-95 & $4.988 \mathrm{E}-02$ & Barium-137m & $1.848 \mathrm{E}-02$ \\
\hline Niobium-95m & $1.059 \mathrm{E}-03$ & Cesium-134 & $5.557 \mathrm{E}-04$ \\
\hline Technetium-99 & $2.867 \mathrm{E}-06$ & Cesium-135 & $5.746 \mathrm{E}-08$ \\
\hline Rhodium-106 & $4.051 \mathrm{E}-02$ & Cesium-137 & $2.009 \mathrm{E}-02$ \\
\hline Ruthenium-106 & $4.051 \mathrm{E}-02$ & Cerium-144 & $2.784 \mathrm{E}-01$ \\
\hline Palladium-107 & $8.455 \mathrm{E}-09$ & Praseodymium-144 & $2.784 \mathrm{E}-01$ \\
\hline Silver-110 & $5.015 \mathrm{E}-08$ & Promethium-147 & $7.022 \mathrm{E}-02$ \\
\hline Silver-110m & $2.507 \mathrm{E}-06$ & Samarium-151 & $1.938 \mathrm{E}-04$ \\
\hline Cadmium-113m & $4.514 \mathrm{E}-10$ & Europium-152 & $3.000 \mathrm{E}-07$ \\
\hline Tin-119m & $4.372 \mathrm{E}-05$ & Europium-154 & $3.038 \mathrm{E}-05$ \\
\hline Tin-121m & $3.943 \mathrm{E}-06$ & Europium-155 & $7.353 \mathrm{E}-04$ \\
\hline Tin-123m & $1.847 \mathrm{E}-05$ & Gadolinium-162 & $9.860 \mathrm{E}-06$ \\
\hline Antimony-125 & $7.985 \mathrm{E}-04$ & Terbium-162 & $9.862 \mathrm{E}-06$ \\
\hline \hline
\end{tabular}

Table 4.7. Fission Product Composition for N Reactor Fuel

\begin{tabular}{||l|c|c||}
\hline \multicolumn{1}{|c|}{ Isotope } & Ci/MTU & Curie $\%$ \\
\hline \hline Strontium-90 & $2.964 \mathrm{E}+03$ & $3.71 \%$ \\
\hline Yttrium-90 & $2.965 \mathrm{E}+03$ & $3.71 \%$ \\
\hline Ruthenium-106 & $8.014 \mathrm{E}+03$ & $10.03 \%$ \\
\hline Rhodium-106 & $8.014 \mathrm{E}+03$ & $10.03 \%$ \\
\hline Cesium-134 & $3.695 \mathrm{E}+02$ & $0.46 \%$ \\
\hline Cesium-137 & $3.436 \mathrm{E}+03$ & $4.30 \%$ \\
\hline Barium-137m & $3.250 \mathrm{E}+03$ & $4.07 \%$ \\
\hline Cerium-144 & $4.071 \mathrm{E}+04$ & $50.93 \%$ \\
\hline Promethium-147 & $1.021 \mathrm{E}+04$ & $12.77 \%$ \\
\hline Sum & $\mathbf{7 . 9 9 3 E + 0 4}$ & $\mathbf{1 0 0 . 0 0 \%}$ \\
\hline \hline
\end{tabular}


Table 4.8. Normalized SWITS Fission Product Factors for N Reactor Fuel Isotopes

\begin{tabular}{||l|c|c||}
\hline \multicolumn{1}{|c|}{ Isotope } & Factor & Curie \% \\
\hline \hline Strontium-90 & 0.01881 & $3.71 \%$ \\
\hline Yttrium-90 & 0.01881 & $3.71 \%$ \\
\hline Ruthenium-106 & 0.04051 & $8.00 \%$ \\
\hline Rhodium-106 & 0.04051 & $8.00 \%$ \\
\hline Cesium-134 & 0.0005557 & $0.11 \%$ \\
\hline Cesium-137 & 0.02009 & $3.97 \%$ \\
\hline Barium-137m & 0.01848 & $3.65 \%$ \\
\hline Cerium-144 & 0.2784 & $54.98 \%$ \\
\hline Promethium-147 & 0.07022 & $13.87 \%$ \\
\hline Sum & $\mathbf{0 . 5 0 6 3 8 5 7}$ & $\mathbf{1 0 0 . 0 0 \%}$ \\
\hline
\end{tabular}

For strontium-90, the SWITS factor and the simulated Mark IV 6\% fuel composition are exactly the same. As such, the selected method for iodine-129 uses strontium-90 as the basis for the factor. The strontium-90 value for simulated Mark IV 6\% fuel 1 year after reactor discharge is 2,964 Ci (Hedengren 1985). The iodine-129 value from the ORIGEN2 runs (Hedengren 1985) is 9.642E-4 Ci at 1 year after fuel discharge from the reactor. The activity of iodine- 129 can obtained be from the activity of strontium-90 as follows:

$$
\frac{9.642 \times 10^{-4} \text { Ci I129 }}{2.964 \times 10^{3} \text { Ci Sr } 90}=3.253 \times 10^{-7} \frac{\text { Ci I129 }}{\text { Ci Sr } 90}
$$

The final fission production factors for the suite of isotopes used in Hanford assessments, normalized to sum to unity, are provided in Table 4.9. These factors are valid for fuel 1 year after discharge from the reactor.

Table 4.9. Fission Product Composition (Ci basis)

\begin{tabular}{||l|c||}
\hline \multicolumn{1}{|c|}{ Isotope } & Final Factor \\
\hline \hline Selenium-79 & $5.27 \mathrm{E}-09$ \\
\hline Strontium-90 & 0.0195 \\
\hline Yttrium-90 & 0.0195 \\
\hline Technetium-99 & $3.02 \mathrm{E}-06$ \\
\hline Iodine-129 & $6.48 \mathrm{E}-09$ \\
\hline Cesium-137 & 0.0213 \\
\hline Barium-137m & 0.0196 \\
\hline Europium-152 & $2.81 \mathrm{E}-07$ \\
\hline Europium-154 & $5.98 \mathrm{E}-05$ \\
\hline Europium-155 & $2.97 \mathrm{E}-04$ \\
\hline Others & 0.9197 \\
\hline Sum & $\mathbf{1 . 0 0 0 0}$ \\
\hline
\end{tabular}




\subsubsection{Adjust Fission Product Factors for Time Delay}

The values in Table 4.9 are the basis for the factors applied to the data, however, they only represent fuel 1 year after discharge from the reactor. The desired factors are a function of fuel age. The values from Table 4.9 were adjusted for radioactive decay and renormalized to sum to unity for up to 11 years after discharge from the reactor. The revised fission product composition as a function of time after discharge from the reactor is provided in Table 4.10.

Table 4.10. Fission Product Composition (Ci basis) as a Function of Time After Fuel Discharge

\begin{tabular}{|c|c|c|c|c|c|c|}
\hline \multirow[b]{2}{*}{ Isotope } & \multicolumn{6}{|c|}{ Number of Years After Discharge From Reactor } \\
\hline & 1 & 2 & 3 & 4 & 5 & 6 \\
\hline Selenium-79 & 5.27E-09 & $1.24 \mathrm{E}-08$ & $2.18 \mathrm{E}-08$ & $3.28 \mathrm{E}-08$ & $4.33 \mathrm{E}-08$ & $5.21 \mathrm{E}-08$ \\
\hline Strontium-90 & 0.0195 & 0.0449 & 0.0767 & 0.1128 & 0.1456 & 0.1708 \\
\hline Yttrium-90 & 0.0195 & 0.0449 & 0.0767 & 0.1128 & 0.1456 & 0.1708 \\
\hline Technetium-99 & $3.02 \mathrm{E}-06$ & $7.11 \mathrm{E}-06$ & $1.25 \mathrm{E}-05$ & $1.88 \mathrm{E}-05$ & $2.48 \mathrm{E}-05$ & $2.98 \mathrm{E}-05$ \\
\hline Iodine-129 & $6.48 \mathrm{E}-09$ & $1.53 \mathrm{E}-08$ & $2.67 \mathrm{E}-08$ & $4.03 \mathrm{E}-08$ & $5.32 \mathrm{E}-08$ & $6.40 \mathrm{E}-08$ \\
\hline Cesium-137 & 0.0213 & 0.0490 & 0.0839 & 0.1235 & 0.1596 & 0.1874 \\
\hline Barium-137m & 0.0196 & 0.0451 & 0.0772 & 0.1136 & 0.1468 & 0.1724 \\
\hline Europium-152 & $2.81 \mathrm{E}-07$ & $6.29 \mathrm{E}-07$ & $1.05 \mathrm{E}-06$ & $1.50 \mathrm{E}-06$ & $1.88 \mathrm{E}-06$ & $2.15 \mathrm{E}-06$ \\
\hline Europium-154 & $5.98 \mathrm{E}-05$ & $1.30 \mathrm{E}-04$ & $2.10 \mathrm{E}-04$ & $2.92 \mathrm{E}-04$ & $3.56 \mathrm{E}-04$ & $3.95 \mathrm{E}-04$ \\
\hline Europium-155 & $2.97 \mathrm{E}-04$ & $6.04 \mathrm{E}-04$ & $9.14 \mathrm{E}-04$ & 1.19E-03 & $1.36 \mathrm{E}-03$ & $1.41 \mathrm{E}-03$ \\
\hline Others & 0.9197 & 0.8154 & 0.6843 & 0.5357 & 0.4008 & 0.2968 \\
\hline Sum & 1.0000 & 1.0000 & 1.0000 & 1.0000 & 1.0000 & 1.0000 \\
\hline \multirow[b]{2}{*}{ Isotope } & \multicolumn{6}{|c|}{ Number of Years After Discharge From Reactor } \\
\hline & 7 & 8 & 9 & 10 & 11 & \\
\hline Selenium-79 & 5.89E-08 & 6.44E-08 & 6.90E-08 & 7.29E-08 & 7.64E-08 & \\
\hline Strontium-90 & 0.1887 & 0.2013 & 0.2104 & 0.2172 & 0.2223 & \\
\hline Yttrium-90 & 0.1887 & 0.2013 & 0.2104 & 0.2172 & 0.2223 & \\
\hline Technetium-99 & $3.37 \mathrm{E}-05$ & $3.69 \mathrm{E}-05$ & $3.95 \mathrm{E}-05$ & $4.17 \mathrm{E}-05$ & $4.38 \mathrm{E}-05$ & \\
\hline Iodine-129 & 7.24E-08 & $7.91 \mathrm{E}-08$ & $8.47 \mathrm{E}-08$ & $8.95 \mathrm{E}-08$ & $9.39 \mathrm{E}-08$ & \\
\hline Cesium-137 & 0.2073 & 0.2214 & 0.2316 & 0.2393 & 0.2452 & \\
\hline Barium-137m & 0.1907 & 0.2036 & 0.2131 & 0.2201 & 0.2255 & \\
\hline Europium-152 & $2.31 \mathrm{E}-06$ & $2.40 \mathrm{E}-06$ & $2.44 \mathrm{E}-06$ & $2.45 \mathrm{E}-06$ & $2.44 \mathrm{E}-06$ & \\
\hline Europium-154 & $4.12 \mathrm{E}-04$ & $4.16 \mathrm{E}-04$ & $4.10 \mathrm{E}-04$ & $4.00 \mathrm{E}-04$ & $3.87 \mathrm{E}-04$ & \\
\hline Europium-155 & $1.38 \mathrm{E}-03$ & $1.30 \mathrm{E}-03$ & $1.21 \mathrm{E}-03$ & $1.10 \mathrm{E}-03$ & $9.99 \mathrm{E}-04$ & \\
\hline Selenium-79 & 0.2228 & 0.1705 & 0.1328 & 0.1047 & 0.0832 & \\
\hline Sum & 1.0000 & 1.0000 & 1.0000 & 1.0000 & 1.0000 & \\
\hline
\end{tabular}

The guidance for selection of a representative fuel age is presented in Table 4.11. The fuel age is related to different periods of fuel reactor operations. For fuel ages greater than 11 years, the assumed fuel age is 11 years because changes in the composition after 11 years are small. This assumption is also made to maintain consistency with other Hanford projects that use these fill-in rules. 
Table 4.11. Representative Fuel Age

\begin{tabular}{||l|l||}
\hline \multicolumn{1}{|c||}{ Time Period } & \multicolumn{1}{c||}{ Fuel Age (yr) } \\
\hline \hline 1944 to 1972 & 1 \\
\hline 1973 to 1983 & $\begin{array}{l}\text { Increase the value by 1 each year, starting with 2 in 1973, up to 11 in } 1982 . \\
\text { Value does not exceed 11. }\end{array}$ \\
\hline 1984 to 1987 & 1 \\
\hline 1988 and later & $\begin{array}{l}\text { Increase the value by 1 each year, starting with 2 in 1988, up to 11 in } 1997 . \\
\text { Value does not exceed 11. }\end{array}$ \\
\hline
\end{tabular}

Factors as a function of fuel age are calculated using the data in Table 4.10. These factors allow the amount (curies) of an unknown isotope to be estimated from the amount (curies) of any one of several known isotopes. The fission product factors as a function of time since the fuel was discharged from the reactor are provided in Table 4.12 .

Table 4.12. Fission Product Ratios as a Function of Years After Reactor Discharge (Ci basis)

\begin{tabular}{|c|c|c|c|c|c|c|c|}
\hline Year & $\begin{array}{l}\text { Unknown } \\
\text { Isotope }\end{array}$ & Selenium-79 & Strontium-90 & Technetium-99 & Iodine-129 & Cesium-137 & Europium-152 \\
\hline 1 & Selenium-79 & 1 & $2.703 \mathrm{E}-07$ & $1.746 \mathrm{E}-03$ & $8.141 \mathrm{E}-01$ & $2.476 \mathrm{E}-07$ & $1.875 \mathrm{E}-02$ \\
\hline 1 & Strontium-90 & $3.700 \mathrm{E}+6$ & 1 & $6.462 \mathrm{E}+3$ & $3.012 \mathrm{E}+6$ & $9.160 \mathrm{E}-1$ & $6.937 \mathrm{E}+04$ \\
\hline 1 & Technetium-99 & $5.726 \mathrm{E}+2$ & $1.548 \mathrm{E}-4$ & 1 & $4.661 \mathrm{E}+2$ & $1.418 \mathrm{E}-4$ & $1.074 \mathrm{E}+01$ \\
\hline 1 & Iodine-129 & $1.228 \mathrm{E}+0$ & $3.320 \mathrm{E}-7$ & $2.145 \mathrm{E}-3$ & 1 & $3.041 \mathrm{E}-7$ & $2.303 \mathrm{E}-02$ \\
\hline 1 & Cesium-137 & $4.039 \mathrm{E}+6$ & $1.092 \mathrm{E}+0$ & $7.054 \mathrm{E}+3$ & $3.288 \mathrm{E}+6$ & 1 & $7.573 \mathrm{E}+04$ \\
\hline 1 & Europium-152 & $5.334 \mathrm{E}+1$ & $1.442 \mathrm{E}-5$ & $9.315 \mathrm{E}-2$ & $4.342 \mathrm{E}+1$ & $1.320 \mathrm{E}-5$ & 1 \\
\hline 2 & Selenium-79 & 1 & $2.769 \mathrm{E}-7$ & $1.746 \mathrm{E}-3$ & $8.141 \mathrm{E}-1$ & $2.533 \mathrm{E}-7$ & $1.973 \mathrm{E}-02$ \\
\hline 2 & Strontium-90 & $3.612 \mathrm{E}+6$ & 1 & $6.308 \mathrm{E}+3$ & $2.940 \mathrm{E}+6$ & $9.151 \mathrm{E}-1$ & $7.127 \mathrm{E}+04$ \\
\hline 2 & Technetium-99 & $5.726 \mathrm{E}+2$ & $1.585 \mathrm{E}-4$ & 1 & $4.661 \mathrm{E}+2$ & $1.451 \mathrm{E}-4$ & $1.130 \mathrm{E}+01$ \\
\hline 2 & Iodine-129 & $1.228 \mathrm{E}+0$ & $3.401 \mathrm{E}-7$ & $2.145 \mathrm{E}-3$ & 1 & $3.112 \mathrm{E}-7$ & $2.424 \mathrm{E}-02$ \\
\hline 2 & Cesium-137 & $3.947 \mathrm{E}+6$ & $1.093 \mathrm{E}+0$ & $6.894 \mathrm{E}+3$ & $3.213 \mathrm{E}+6$ & 1 & $7.789 \mathrm{E}+04$ \\
\hline 2 & Europium-152 & $5.068 \mathrm{E}+1$ & $1.403 \mathrm{E}-5$ & $8.850 \mathrm{E}-2$ & $4.125 \mathrm{E}+1$ & $1.284 \mathrm{E}-5$ & 1 \\
\hline 3 & Selenium-79 & 1 & $2.836 \mathrm{E}-7$ & $1.746 \mathrm{E}-3$ & $8.141 \mathrm{E}-1$ & $2.592 \mathrm{E}-7$ & $2.077 \mathrm{E}-02$ \\
\hline 3 & Strontium-90 & $3.526 \mathrm{E}+6$ & 1 & $6.158 \mathrm{E}+3$ & $2.870 \mathrm{E}+6$ & $9.141 \mathrm{E}-1$ & $7.323 \mathrm{E}+04$ \\
\hline 3 & Technetium-99 & $5.726 \mathrm{E}+2$ & $1.624 \mathrm{E}-4$ & 1 & $4.661 \mathrm{E}+2$ & $1.484 \mathrm{E}-4$ & $1.189 \mathrm{E}+01$ \\
\hline 3 & Iodine-129 & $1.228 \mathrm{E}+0$ & $3.484 \mathrm{E}-7$ & $2.145 \mathrm{E}-3$ & 1 & $3.185 \mathrm{E}-7$ & $2.551 \mathrm{E}-02$ \\
\hline 3 & Cesium-137 & $3.857 \mathrm{E}+6$ & $1.094 \mathrm{E}+0$ & $6.736 \mathrm{E}+3$ & $3.140 \mathrm{E}+6$ & 1 & $8.011 \mathrm{E}+04$ \\
\hline 3 & Europium-152 & $4.815 \mathrm{E}+1$ & $1.366 \mathrm{E}-5$ & $8.409 \mathrm{E}-2$ & $3.920 \mathrm{E}+1$ & $1.248 \mathrm{E}-5$ & 1 \\
\hline 4 & Selenium-79 & 1 & $2.905 \mathrm{E}-7$ & $1.746 \mathrm{E}-3$ & $8.141 \mathrm{E}-1$ & $2.653 \mathrm{E}-7$ & $2.186 \mathrm{E}-02$ \\
\hline 4 & Strontium-90 & $3.442 \mathrm{E}+6$ & 1 & $6.011 \mathrm{E}+3$ & $2.802 \mathrm{E}+6$ & $9.132 \mathrm{E}-1$ & $7.524 \mathrm{E}+04$ \\
\hline 4 & Technetium-99 & $5.726 \mathrm{E}+2$ & $1.664 \mathrm{E}-4$ & 1 & $4.661 \mathrm{E}+2$ & $1.519 \mathrm{E}-4$ & $1.252 \mathrm{E}+01$ \\
\hline 4 & Iodine-129 & $1.228 \mathrm{E}+0$ & $3.569 \mathrm{E}-7$ & $2.145 \mathrm{E}-3$ & 1 & $3.2588 \mathrm{E}-7$ & $2.685 \mathrm{E}-02$ \\
\hline 4 & Cesium-137 & $3.769 \mathrm{E}+6$ & $1.095 \mathrm{E}+0$ & $6.583 \mathrm{E}+3$ & $3.069 \mathrm{E}+6$ & 1 & $8.240 \mathrm{E}+04$ \\
\hline 4 & Europium-152 & $4.575 \mathrm{E}+1$ & $1.329 \mathrm{E}-5$ & $7.989 \mathrm{E}-2$ & $3.724 \mathrm{E}+1$ & $1.214 \mathrm{E}-5$ & 1 \\
\hline 5 & Selenium-79 & 1 & $2.976 \mathrm{E}-7$ & $1.746 \mathrm{E}-3$ & $8.141 \mathrm{E}-1$ & $2.715 \mathrm{E}-7$ & $2.301 \mathrm{E}-02$ \\
\hline 5 & Strontium-90 & $3.360 \mathrm{E}+6$ & 1 & $5.868 \mathrm{E}+3$ & $2.735 \mathrm{E}+6$ & $9.122 \mathrm{E}-1$ & $7.731 \mathrm{E}+04$ \\
\hline 5 & Technetium-99 & $5.726 \mathrm{E}+2$ & $1.704 \mathrm{E}-4$ & 1 & $4.661 \mathrm{E}+2$ & $1.554 \mathrm{E}-4$ & $1.317 \mathrm{E}+01$ \\
\hline 5 & Iodine-129 & $1.228 \mathrm{E}+0$ & $3.656 \mathrm{E}-7$ & $2.145 \mathrm{E}-3$ & 1 & $3.335 \mathrm{E}-7$ & $2.826 \mathrm{E}-02$ \\
\hline
\end{tabular}


Table 4.12. (contd)

\begin{tabular}{|c|c|c|c|c|c|c|c|}
\hline Year & $\begin{array}{l}\text { Unknown } \\
\text { Isotope }\end{array}$ & Selenium-79 & Strontium-90 & Technetium-99 & Iodine-129 & Cesium-137 & Europium-152 \\
\hline 5 & Cesium-137 & $3.684 \mathrm{E}+6$ & $1.096 \mathrm{E}+0$ & $6.433 \mathrm{E}+3$ & $2.999 \mathrm{E}+6$ & 1 & $8.475 \mathrm{E}+04$ \\
\hline 5 & Europium-152 & $4.346 \mathrm{E}+1$ & $1.293 \mathrm{E}-5$ & $7.590 \mathrm{E}-2$ & $3.538 \mathrm{E}+1$ & $1.180 \mathrm{E}-5$ & 1 \\
\hline 6 & Selenium-79 & 1 & $3.049 \mathrm{E}-7$ & $1.746 \mathrm{E}-3$ & $8.141 \mathrm{E}-1$ & $2.778 \mathrm{E}-7$ & $2.422 \mathrm{E}-02$ \\
\hline 6 & Strontium-90 & $3.280 \mathrm{E}+6$ & 1 & $5.729 \mathrm{E}+3$ & $2.670 \mathrm{E}+6$ & $9.113 \mathrm{E}-1$ & $7.944 \mathrm{E}+04$ \\
\hline 6 & Technetium-99 & $5.726 \mathrm{E}+2$ & $1.746 \mathrm{E}-4$ & 1 & $4.661 \mathrm{E}+2$ & $1.591 \mathrm{E}-4$ & $1.387 \mathrm{E}+01$ \\
\hline 6 & Iodine-129 & $1.228 \mathrm{E}+0$ & $3.745 \mathrm{E}-7$ & $2.145 \mathrm{E}-3$ & 1 & $3.413 \mathrm{E}-7$ & $2.975 \mathrm{E}-02$ \\
\hline 6 & Cesium-137 & $3.600 \mathrm{E}+6$ & $1.097 \mathrm{E}+0$ & $6.286 \mathrm{E}+3$ & $2.930 \mathrm{E}+6$ & 1 & $8.717 \mathrm{E}+04$ \\
\hline 6 & Europium-152 & $4.129 \mathrm{E}+1$ & $1.259 \mathrm{E}-5$ & $7.212 \mathrm{E}-2$ & $3.362 \mathrm{E}+1$ & $1.147 \mathrm{E}-5$ & 1 \\
\hline 7 & Selenium-79 & 1 & $3.123 \mathrm{E}-7$ & $1.746 \mathrm{E}-3$ & $8.141 \mathrm{E}-1$ & $2.843 \mathrm{E}-7$ & $2.549 \mathrm{E}-02$ \\
\hline 7 & Strontium-90 & $3.202 \mathrm{E}+6$ & 1 & $5.592 \mathrm{E}+3$ & $2.607 \mathrm{E}+6$ & $9.103 \mathrm{E}-1$ & $8.162 \mathrm{E}+04$ \\
\hline 7 & Technetium-99 & $5.726 \mathrm{E}+2$ & $1.788 \mathrm{E}-4$ & 1 & $4.661 \mathrm{E}+2$ & $1.628 \mathrm{E}-4$ & $1.459 \mathrm{E}+01$ \\
\hline 7 & Iodine-129 & $1.228 \mathrm{E}+0$ & $3.836 \mathrm{E}-7$ & $2.145 \mathrm{E}-3$ & 1 & $3.492 \mathrm{E}-7$ & $3.131 \mathrm{E}-02$ \\
\hline 7 & Cesium-137 & $3.518 \mathrm{E}+6$ & $1.098 \mathrm{E}+0$ & $6.143 \mathrm{E}+3$ & $2.864 \mathrm{E}+6$ & 1 & $8.966 \mathrm{E}+04$ \\
\hline 7 & Europium-152 & $3.923 \mathrm{E}+1$ & $1.225 \mathrm{E}-5$ & $6.852 \mathrm{E}-2$ & $3.194 \mathrm{E}+1$ & $1.115 \mathrm{E}-5$ & 1 \\
\hline 8 & Selenium-79 & 1 & $3.199 \mathrm{E}-7$ & $1.746 \mathrm{E}-3$ & $8.141 \mathrm{E}-1$ & $2.909 \mathrm{E}-7$ & $2.683 \mathrm{E}-02$ \\
\hline 8 & Strontium-90 & $3.126 \mathrm{E}+6$ & 1 & $5.459 \mathrm{E}+3$ & $2.545 \mathrm{E}+6$ & $9.094 \mathrm{E}-1$ & $8.386 \mathrm{E}+04$ \\
\hline 8 & Technetium-99 & $5.726 \mathrm{E}+2$ & $1.832 \mathrm{E}-4$ & 1 & $4.661 \mathrm{E}+2$ & $1.666 \mathrm{E}-4$ & $1.536 \mathrm{E}+01$ \\
\hline 8 & Iodine-129 & $1.228 \mathrm{E}+0$ & $3.930 \mathrm{E}-7$ & $2.145 \mathrm{E}-3$ & 1 & $3.574 \mathrm{E}-7$ & $3.295 \mathrm{E}-02$ \\
\hline 8 & Cesium-137 & $3.437 \mathrm{E}+6$ & $1.100 \mathrm{E}+0$ & $6.003 \mathrm{E}+3$ & $2.798 \mathrm{E}+6$ & 1 & $9.222 \mathrm{E}+04$ \\
\hline 8 & Europium-152 & $3.727 \mathrm{E}+1$ & $1.192 \mathrm{E}-5$ & $6.510 \mathrm{E}-2$ & $3.034 \mathrm{E}+1$ & $1.084 \mathrm{E}-5$ & 1 \\
\hline 9 & Selenium-79 & 1 & $3.277 \mathrm{E}-7$ & $1.746 \mathrm{E}-3$ & $8.141 \mathrm{E}-1$ & $2.977 \mathrm{E}-7$ & $2.824 \mathrm{E}-02$ \\
\hline 9 & Strontium-90 & $3.052 \mathrm{E}+6$ & 1 & $5.329 \mathrm{E}+3$ & $2.484 \mathrm{E}+6$ & $9.085 \mathrm{E}-1$ & $8.617 \mathrm{E}+04$ \\
\hline 9 & Technetium-99 & $5.726 \mathrm{E}+2$ & $1.876 \mathrm{E}-4$ & 1 & $4.661 \mathrm{E}+2$ & $1.705 \mathrm{E}-4$ & $1.617 \mathrm{E}+01$ \\
\hline 9 & Iodine-129 & $1.228 \mathrm{E}+0$ & $4.025 \mathrm{E}-7$ & $2.145 \mathrm{E}-3$ & 1 & $3.657 \mathrm{E}-7$ & $3.469 \mathrm{E}-02$ \\
\hline 9 & Cesium-137 & $3.359 \mathrm{E}+6$ & $1.101 \mathrm{E}+0$ & $5.866 \mathrm{E}+3$ & $2.735 \mathrm{E}+6$ & 1 & $9.485 \mathrm{E}+04$ \\
\hline 9 & Europium-152 & $3.541 \mathrm{E}+1$ & $1.161 \mathrm{E}-5$ & $6.185 \mathrm{E}-2$ & $2.883 \mathrm{E}+1$ & $1.054 \mathrm{E}-5$ & 1 \\
\hline 10 & Selenium-79 & 1 & $3.357 \mathrm{E}-7$ & $1.746 \mathrm{E}-3$ & $8.141 \mathrm{E}-1$ & $3.046 \mathrm{E}-7$ & $2.972 \mathrm{E}-02$ \\
\hline 10 & Strontium-90 & $2.979 \mathrm{E}+6$ & 1 & $5.203 E+3$ & $2.425 \mathrm{E}+6$ & $9.075 \mathrm{E}-1$ & $8.854 \mathrm{E}+04$ \\
\hline 10 & Technetium-99 & $5.726 \mathrm{E}+2$ & $1.922 \mathrm{E}-4$ & 1 & $4.661 \mathrm{E}+2$ & $1.744 \mathrm{E}-4$ & $1.702 \mathrm{E}+01$ \\
\hline 10 & Iodine-129 & $1.228 \mathrm{E}+0$ & $4.124 \mathrm{E}-7$ & $2.145 \mathrm{E}-3$ & 1 & $3.742 \mathrm{E}-7$ & $3.651 \mathrm{E}-02$ \\
\hline 10 & Cesium-137 & $3.283 \mathrm{E}+6$ & $1.102 \mathrm{E}+0$ & $5.733 \mathrm{E}+3$ & $2.672 \mathrm{E}+6$ & 1 & $9.756 \mathrm{E}+04$ \\
\hline 10 & Europium-152 & $3.365 \mathrm{E}+1$ & $1.129 \mathrm{E}-5$ & $5.876 \mathrm{E}-2$ & $2.739 \mathrm{E}+1$ & $1.025 \mathrm{E}-5$ & 1 \\
\hline 11 & Selenium-79 & 1 & $3.439 \mathrm{E}-7$ & $1.746 \mathrm{E}-3$ & $8.141 \mathrm{E}-1$ & $3.117 \mathrm{E}-7$ & $3.128 \mathrm{E}-02$ \\
\hline 11 & Strontium-90 & $2.908 \mathrm{E}+6$ & 1 & $5.079 \mathrm{E}+3$ & $2.367 \mathrm{E}+6$ & $9.066 \mathrm{E}-1$ & $9.097 \mathrm{E}+04$ \\
\hline 11 & Technetium-99 & $5.726 \mathrm{E}+2$ & $1.969 \mathrm{E}-4$ & 1 & $4.661 \mathrm{E}+2$ & $1.785 \mathrm{E}-4$ & $1.791 \mathrm{E}+01$ \\
\hline 11 & Iodine-129 & $1.228 \mathrm{E}+0$ & $4.224 \mathrm{E}-7$ & $2.145 \mathrm{E}-3$ & 1 & $3.829 \mathrm{E}-7$ & $3.843 \mathrm{E}-02$ \\
\hline 11 & Cesium-137 & $3.208 \mathrm{E}+6$ & $1.103 \mathrm{E}+0$ & $5.602 \mathrm{E}+3$ & $2.611 \mathrm{E}+6$ & 1 & $1.003 \mathrm{E}+05$ \\
\hline 11 & Europium-152 & $3.197 \mathrm{E}+1$ & $1.099 \mathrm{E}-5$ & $5.583 \mathrm{E}-2$ & $2.602 \mathrm{E}+1$ & $9.966 \mathrm{E}-6$ & 1 \\
\hline
\end{tabular}




\subsection{Fill-In Rules for Activation Products}

The fill-in rules for activation products start with fuel compositions reported in SWITS (Hanson et al. 1973). The fuel composition description is then expanded to include europium-152. Finally, the activation product ratios are adjusted to account for the delay in time from reactor discharge to the time of fuel dissolution.

\subsubsection{Develop Activation Product Factors}

The activation product factors (relative abundance of difference isotopes) were obtained from SWITS (Hanson et al. 1973) and are provided in Table 4.13. The fuel age is not explicitly given, but values appear to be valid for fuel 1 year after discharge from the reactor.

Table 4.13. Activation Product Factors from SWITS (Ci basis)

\begin{tabular}{||l|c||}
\hline \multicolumn{1}{|c|}{ Isotope } & Amount $(\mathrm{Ci})$ \\
\hline \hline Carbon-14 & 0.01 \\
\hline Manganese-54 & 0.07 \\
\hline Cobalt-58 & 0.01 \\
\hline Iron-59 & 0.04 \\
\hline Cobalt-60 & 0.67 \\
\hline Cesium-137 & 0.0103 \\
\hline Barium-137m & 0.0097 \\
\hline Europium-154 & 0.085 \\
\hline Europium-155 & 0.085 \\
\hline Sum & $\mathbf{0 . 9 9}$ \\
\hline
\end{tabular}

When europium-155 and europium-154 are reported in SWITS, the expectation is that europium-152 is reported as well. As such, a factor for europium-152 needs to be developed. Simulated fuel compositions as a function of time for $\mathrm{N}$ Reactor fuel have been developed (Hedengren 1985). Composition values are collected from the fission product tables rather than the activation product tables because the activation product tables do not provide values for europium-152, europium-154, and europium-155. Composition values for simulated Mark IV 6\% plutonium-240 fuel at 1 year after reactor discharge are the following: europium-152, 9.015E-4 Ci/MTU; europium-154, 9.325E-2 Ci/MTU, and europium-155, 1.509E-1 Ci/MTU. The sum of europium-154 and europium-155 factors for SWITS and ORIGEN2 are provided in Table 4.14 .

Table 4.14. Sum of Europium-154 and Europium-155 Factors for SWITS and ORIGEN2

\begin{tabular}{||l|c|c||}
\hline \hline \multicolumn{1}{|c|}{ Isotope } & $\begin{array}{c}\text { SWITS } \\
(\mathrm{Ci})\end{array}$ & $\begin{array}{c}\text { ORIGEN2 } \\
\text { Ci/MTU }\end{array}$ \\
\hline \hline Europium-154 & 0.085 & 0.09325 \\
\hline Europium-155 & 0.085 & 0.15090 \\
\hline Sum & $\mathbf{0 . 1 7}$ & $\mathbf{0 . 2 4 4 1 5}$ \\
\hline
\end{tabular}


An activation product factor for europium-152 is developed by multiplying the ORIGEN2 value of 9.015E-4 Ci by the ratio of the SWITS sum to the ORIGEN2 sum from Table 4.14. This results in an europium-152 factor of $0.0006 \mathrm{Ci}$.

A final adjustment was made so the activation factors sum to unit. The adjustments are shown in Table 4.15. The final factors are shown in the right column of this table.

Table 4.15. Final Adjusted Activation Product Factors

\begin{tabular}{||l|c|c|c||}
\hline \hline \multicolumn{1}{|c|}{ Isotope } & $\begin{array}{c}\text { Derived } \\
(\mathrm{Ci})\end{array}$ & $\begin{array}{c}\text { Adjustment } \\
(\mathrm{Ci})\end{array}$ & $\begin{array}{c}\text { Final Factor } \\
(\mathrm{Ci})\end{array}$ \\
\hline \hline Carbon-14 & 0.01 & & 0.01 \\
\hline Manganese-54 & 0.07 & & 0.07 \\
\hline Cobalt-58 & 0.01 & & 0.01 \\
\hline Iron-59 & 0.04 & & 0.04 \\
\hline Cobalt-60 & 0.67 & 0.006 & 0.676 \\
\hline Cesium-137 & 0.0103 & 0.0007 & 0.011 \\
\hline Barium-137m & 0.0097 & 0.0006 & 0.0103 \\
\hline Europium-152 & 0.0006 & 0.0001 & 0.0007 \\
\hline Europium-154 & 0.085 & 0.001 & 0.086 \\
\hline Europium-155 & 0.085 & 0.001 & 0.086 \\
\hline Sum & $\mathbf{0 . 9 9 0 6}$ & $\mathbf{0 . 0 0 9 4}$ & $\mathbf{1}$ \\
\hline \hline
\end{tabular}

\subsubsection{Adjust Activation Product Factors for Time Delay}

The values in Table 4.15 are the basis for the factors are applied to the data, however, they only represent fuel 1 year after discharge from the reactor. The desired factors are a function of fuel age. The values from Table 4.15 were adjusted for radioactive decay and renormalized to sum to unity for up to 11 years after discharge from the reactor. The revised activation product composition as a function of time after discharge from the reactor is provided in Table 4.16.

Table 4.16. Activation Product Composition (Ci basis) as a Function of Time After Fuel Discharge

\begin{tabular}{||l|c|c|c|c|c|c|c|c|c|c|c||}
\hline \multirow{2}{*}{\multicolumn{1}{|c|}{ Isotope }} & \multicolumn{10}{|c|}{ Number of Years After Reactor Discharge } \\
\cline { 2 - 12 } & 1 & 2 & 3 & 4 & 5 & 6 & 7 & 8 & 9 & 10 & 11 \\
\hline \hline Carbon-14 & 0.0100 & 0.0124 & 0.0142 & 0.0162 & 0.0184 & 0.0208 & 0.0235 & 0.0264 & 0.0297 & 0.0334 & 0.0374 \\
\hline Cobalt-60 & 0.6760 & 0.7323 & 0.7404 & 0.7405 & 0.7364 & 0.7299 & 0.7217 & 0.7124 & 0.7022 & 0.6911 & 0.6792 \\
\hline Cesium-137 & 0.0110 & 0.0133 & 0.0150 & 0.0167 & 0.0185 & 0.0204 & 0.0225 & 0.0248 & 0.0272 & 0.0298 & 0.0327 \\
\hline Barium-137m & 0.0103 & 0.0124 & 0.0140 & 0.0156 & 0.0173 & 0.0191 & 0.0211 & 0.0232 & 0.0255 & 0.0279 & 0.0306 \\
\hline Europium-152 & 0.0007 & 0.0008 & 0.0009 & 0.0010 & 0.0011 & 0.0011 & 0.0012 & 0.0013 & 0.0014 & 0.0015 & 0.0016 \\
\hline Europium-154 & 0.0860 & 0.0980 & 0.1043 & 0.1097 & 0.1148 & 0.1197 & 0.1246 & 0.1294 & 0.1342 & 0.1389 & 0.1437 \\
\hline Europium-155 & 0.0860 & 0.0918 & 0.0915 & 0.0902 & 0.0884 & 0.0864 & 0.0842 & 0.0819 & 0.0796 & 0.0772 & 0.0748 \\
\hline Others & 0.1200 & 0.0389 & 0.0197 & 0.0100 & 0.0050 & 0.0025 & 0.0013 & 0.0006 & 0.0003 & 0.0002 & 0.0001 \\
\hline Sum & $\mathbf{1 . 0 0 0 0}$ & $\mathbf{1 . 0 0 0 0}$ & $\mathbf{1 . 0 0 0 0}$ & $\mathbf{1 . 0 0 0 0}$ & $\mathbf{1 . 0 0 0 0}$ & $\mathbf{1 . 0 0 0 0}$ & $\mathbf{1 . 0 0 0 0}$ & $\mathbf{1 . 0 0 0 0}$ & $\mathbf{1 . 0 0 0 0}$ & $\mathbf{1 . 0 0 0 0}$ & $\mathbf{1 . 0 0 0 0}$ \\
\hline \hline
\end{tabular}


The guidance for selecting a representative fuel age for fission product rules is presented in Table 4.11. The guidance is applied for activation product rules.

Factors as a function of fuel age are calculated using the data in Table 4.16. These factors allow the amount (curies) of an unknown isotope to be estimated from the amount (curies) of any one of several known isotopes. The activation product factors as a function of time since the fuel was discharged from the reactor are provided in Table 4.17.

Table 4.17. Activation Product Ratios as a Function of Time Since Fuel Discharge from the Reactor

\begin{tabular}{|c|c|c|c|c|c|c|c|}
\hline \multirow[b]{2}{*}{ Years } & \multirow{2}{*}{$\begin{array}{l}\text { Unknown } \\
\text { Isotope }\end{array}$} & \multicolumn{6}{|c|}{ Known Isotope } \\
\hline & & Carbon-14 & Cobalt-60 & Cesium-137 & Europium-152 & Europium-154 & Europium-155 \\
\hline 1 & Carbon-14 & 1 & $1.48 \mathrm{E}-2$ & $9.09 \mathrm{E}-1$ & $1.43 \mathrm{E}+1$ & $1.16 \mathrm{E}-1$ & $1.16 \mathrm{E}-1$ \\
\hline 1 & Cesium-137 & $1.10 \mathrm{E}+0$ & $1.63 \mathrm{E}-2$ & 1 & $1.57 \mathrm{E}+1$ & $1.28 \mathrm{E}-1$ & $1.28 \mathrm{E}-1$ \\
\hline 1 & Europium-152 & $7.00 \mathrm{E}-2$ & $1.04 \mathrm{E}-3$ & $6.36 \mathrm{E}-2$ & 1 & $8.14 \mathrm{E}-3$ & $8.14 \mathrm{E}-3$ \\
\hline 2 & Carbon-14 & 1 & $1.69 \mathrm{E}-2$ & $9.30 \mathrm{E}-1$ & $1.50 \mathrm{E}+1$ & $1.26 \mathrm{E}-1$ & $1.35 \mathrm{E}-1$ \\
\hline 2 & Cesium-137 & $1.08 \mathrm{E}+0$ & $1.81 \mathrm{E}-2$ & 1 & $1.62 \mathrm{E}+1$ & $1.35 \mathrm{E}-1$ & $1.45 \mathrm{E}-1$ \\
\hline 2 & Europium-152 & $6.65 \mathrm{E}-2$ & $1.12 \mathrm{E}-3$ & $6.19 \mathrm{E}-2$ & 1 & $8.38 \mathrm{E}-3$ & $8.95 \mathrm{E}-3$ \\
\hline 3 & Carbon-14 & 1 & $1.92 \mathrm{E}-2$ & $9.52 \mathrm{E}-1$ & $1.58 \mathrm{E}+1$ & $1.37 \mathrm{E}-1$ & $1.56 \mathrm{E}-1$ \\
\hline 3 & Cesium-137 & $1.05 \mathrm{E}+0$ & $2.02 \mathrm{E}-2$ & 1 & $1.66 \mathrm{E}+1$ & $1.44 \mathrm{E}-1$ & $1.64 \mathrm{E}-1$ \\
\hline 3 & Europium-152 & $6.32 \mathrm{E}-2$ & $1.22 \mathrm{E}-3$ & $6.02 \mathrm{E}-2$ & 1 & $8.63 \mathrm{E}-3$ & $9.84 \mathrm{E}-3$ \\
\hline 4 & Carbon-14 & 1 & $2.19 \mathrm{E}-2$ & $9.74 \mathrm{E}-1$ & $1.67 \mathrm{E}+1$ & $1.48 \mathrm{E}-1$ & $1.80 \mathrm{E}-1$ \\
\hline 4 & Cesium-137 & $1.03 \mathrm{E}+0$ & $2.25 \mathrm{E}-2$ & 1 & $1.71 \mathrm{E}+1$ & $1.52 \mathrm{E}-1$ & $1.85 \mathrm{E}-1$ \\
\hline 4 & Europium-152 & $6.01 \mathrm{E}-2$ & $1.32 \mathrm{E}-3$ & $5.85 \mathrm{E}-2$ & 1 & $8.89 \mathrm{E}-3$ & $1.08 \mathrm{E}-2$ \\
\hline 5 & Carbon-14 & 1 & $2.50 \mathrm{E}-2$ & $9.96 \mathrm{E}-1$ & $1.75 \mathrm{E}+1$ & $1.60 \mathrm{E}-1$ & $2.08 \mathrm{E}-1$ \\
\hline 5 & Cesium-137 & $1.00 \mathrm{E}+0$ & $2.51 \mathrm{E}-2$ & 1 & $1.76 \mathrm{E}+1$ & $1.61 \mathrm{E}-1$ & $2.09 \mathrm{E}-1$ \\
\hline 5 & Europium-152 & $5.71 \mathrm{E}-2$ & $1.43 \mathrm{E}-3$ & $5.69 \mathrm{E}-2$ & 1 & $9.16 \mathrm{E}-3$ & $1.19 \mathrm{E}-2$ \\
\hline 6 & Carbon-14 & 1 & $2.85 \mathrm{E}-2$ & $1.02 \mathrm{E}+0$ & $1.84 \mathrm{E}+1$ & $1.74 \mathrm{E}-1$ & $2.41 \mathrm{E}-1$ \\
\hline 6 & Cesium-137 & $9.81 \mathrm{E}-1$ & $2.80 \mathrm{E}-2$ & 1 & $1.81 \mathrm{E}+1$ & $1.71 \mathrm{E}-1$ & $2.36 \mathrm{E}-1$ \\
\hline 6 & Europium-152 & $5.42 \mathrm{E}-2$ & $1.55 \mathrm{E}-3$ & $5.53 \mathrm{E}-2$ & 1 & $9.43 \mathrm{E}-3$ & $1.31 \mathrm{E}-2$ \\
\hline 7 & Carbon-14 & 1 & $3.25 \mathrm{E}-2$ & $1.04 \mathrm{E}+0$ & $1.94 \mathrm{E}+1$ & $1.89 \mathrm{E}-1$ & $2.79 \mathrm{E}-1$ \\
\hline 7 & Cesium-137 & $9.59 \mathrm{E}-1$ & $3.12 \mathrm{E}-2$ & 1 & $1.86 \mathrm{E}+1$ & $1.81 \mathrm{E}-1$ & $2.67 \mathrm{E}-1$ \\
\hline 7 & Europium-152 & $5.15 \mathrm{E}-2$ & $1.68 \mathrm{E}-3$ & $5.37 \mathrm{E}-2$ & 1 & $9.71 \mathrm{E}-3$ & $1.44 \mathrm{E}-2$ \\
\hline 8 & Carbon-14 & 1 & $3.71 \mathrm{E}-2$ & $1.07 \mathrm{E}+0$ & $2.04 \mathrm{E}+1$ & $2.04 \mathrm{E}-1$ & $3.23 \mathrm{E}-1$ \\
\hline 8 & Cesium-137 & $9.37 \mathrm{E}-1$ & $3.48 \mathrm{E}-2$ & 1 & $1.91 \mathrm{E}+1$ & $1.91 \mathrm{E}-1$ & $3.02 \mathrm{E}-1$ \\
\hline 8 & Europium-152 & $4.90 \mathrm{E}-2$ & $1.82 \mathrm{E}-3$ & $5.23 \mathrm{E}-2$ & 1 & $1.00 \mathrm{E}-2$ & $1.58 \mathrm{E}-2$ \\
\hline 9 & Carbon-14 & 1 & $4.23 \mathrm{E}-2$ & $1.09 \mathrm{E}+0$ & $2.15 \mathrm{E}+1$ & $2.21 \mathrm{E}-1$ & $3.73 \mathrm{E}-1$ \\
\hline 9 & Cesium-137 & $9.16 \mathrm{E}-1$ & $3.87 \mathrm{E}-2$ & 1 & $1.97 \mathrm{E}+1$ & $2.03 \mathrm{E}-1$ & $3.42 \mathrm{E}-1$ \\
\hline 9 & Europium-152 & $4.65 \mathrm{E}-2$ & $1.97 \mathrm{E}-3$ & $5.08 \mathrm{E}-2$ & 1 & $1.03 \mathrm{E}-2$ & $1.74 \mathrm{E}-2$ \\
\hline 10 & Carbon-14 & 1 & $4.83 \mathrm{E}-2$ & $1.12 \mathrm{E}+0$ & $2.26 \mathrm{E}+1$ & $2.40 \mathrm{E}-1$ & 4.32E-1 \\
\hline 10 & Cesium-137 & $8.95 \mathrm{E}-1$ & 4.32E-2 & 1 & $2.02 \mathrm{E}+1$ & $2.15 \mathrm{E}-1$ & $3.87 \mathrm{E}-1$ \\
\hline 10 & Europium-152 & $4.42 \mathrm{E}-2$ & $2.13 \mathrm{E}-3$ & $4.94 \mathrm{E}-2$ & 1 & $1.06 \mathrm{E}-2$ & $1.91 \mathrm{E}-2$ \\
\hline 11 & Carbon-14 & 1 & $5.50 \mathrm{E}-2$ & $1.14 \mathrm{E}+0$ & $2.38 \mathrm{E}+1$ & $2.60 \mathrm{E}-1$ & $5.00 \mathrm{E}-1$ \\
\hline 11 & Cesium-137 & $8.75 \mathrm{E}-1$ & $4.81 \mathrm{E}-2$ & 1 & $2.08 \mathrm{E}+1$ & $2.28 \mathrm{E}-1$ & $4.37 \mathrm{E}-1$ \\
\hline 11 & Europium-152 & $4.20 \mathrm{E}-2$ & $2.31 \mathrm{E}-3$ & $4.80 \mathrm{E}-2$ & 1 & $1.09 \mathrm{E}-2$ & $2.10 \mathrm{E}-2$ \\
\hline
\end{tabular}




\subsection{Applications of Fill-In Rules}

Application of the fill-in rules for inventory estimation is described in four general categories in Sections 4.4.1 through 4.4.4. These categories are: special application of fission product rules to fuel failure releases, general application of uranium fill-in rules, general application of fission product rules and general application of activation product rules.

\subsubsection{Fuel Failures}

During the operational era (1963-1986), N Reactor cooling water associated with fuel element failures was directed to the 1301 and 1325 trenches. Today those trenches are known as the 116-N-1 and 116-N-3 waste sites, respectively. Because these trenches received N Reactor coolant contaminated when fuel elements failed, it is appropriate to use the fission product fill-in rules for these sites. Since the annual inventory of record would reflect fuel failures of that year, the fuel ratio method in Table 4.12 for fuel of 1-year age was used. This set of rules applied to the following six analytes: selenium-79, strontium-90, technetium-99, iodine-129, cesium-137, and europium-152 for all years that releases occurred at the two sites 116-N-1 and 116-N-3. The fill-in rule is invoked only if needed to supplement the data from the inventory database. Inventories associated with fuel element failures for the eight single-pass reactors are described in Section 5.3.

\subsubsection{Uranium}

The uranium record is assumed to be complete for uranium-233, thus no fill-in rules are implemented for this isotope. The factors in Table 4.5 were used to estimate isotopic ratios for uranium-234, uranium-235, and uranium-238, and fill in missing data. These rules were applied to the union of waste sites flagged for fission-product and activation-product fill-in rules, or, in this case, 482 waste sites (see Appendix B). Although the rules are available for a large number of sites, they are involved only when at least one uranium inventory of record exists (i.e., a uranium isotope or total inventory). Thus, they are applied only to supplement or fill-in existing uranium data.

\subsubsection{Fission Product}

Fission product rules apply to the inventory of the following six analytes: selenium-79, strontium-90, technetium-99, iodine-129, cesium-137, and europium-152. As shown in Table 4.12, the rule depends on the number of years after the fuel is discharged from the reactor. The following general rules were applied in choosing which section of data from Table 4.12 to apply:

- All releases before 1973 used the data for year 1.

- All releases for 1973 used the data for year 2.

- All releases from 1974 through 1983 used the data for years 3 through 11.

- All releases from 1984 through 1987, as the PUREX Plant began processing newly spent fuel, created releases used the data from year 1 .

- In years 1988 through 1996, releases used the data for years 2 through 10, respectively.

- In 1997 and all succeeding years, the data for year 11 were used. 
These fission product rules were applied to a total of 301 sites (see Appendix B). Although the rules are available for a large number of sites, they are invoked only if needed to supplement the data from the inventory database.

\subsubsection{Activation Product}

Activation product rules apply to the inventory of the following three analytes: carbon-14, cesium-137, and europium-152. As shown in Table 4.17, the rule depends on the number of years after the fuel is discharged from the reactor. The following general rules were applied in choosing which section of data from Table 4.12 to apply:

- All releases before 1973 used the data for year 1.

- All releases for 1973 used the data for year 2.

- All releases from 1974 through 1983 used the data for years 3 through 11.

- All releases from 1984 through 1987, as the PUREX Plant began processing newly spent fuel, created releases used the data from year 1 .

- In years 1988 through 1996, releases used the data for years 2 through 10, respectively.

- In 1997 and all succeeding years, the data for year 11 were used.

These activation product rules were applied to a total of 181 sites (see Appendix B). Although the rules are available for a large number of sites, they are invoked only if needed to supplement the data from the inventory database.

\subsection{Surrogate Site Rules}

Historical documentation indicates that releases occurred at a number of sites, but no direct record inventory information is available. Surrogate rules have been developed for some of these sites. Application of the surrogate site rule is limited to those sites where a waste volume has been reported or can be estimated but the concentrations of analytes in the waste stream are unknown. In some cases, based on historical records or process knowledge, the same (or a similar) waste stream was routed to another site, called the surrogate site, and concentrations of analytes are available for that waste stream. The surrogate site rule simply takes the concentrations of analytes in the surrogate waste stream and applies them unchanged to the site with unknown concentrations.

Surrogate site rules are applied to waste streams at 52 sites. Appendix C provides summary information on the surrogate rule for each of these sites. The inventory of each radionuclide added by application of surrogate rules (best estimate case) is shown in Table 4.18. The data are for inventory introduced to the modeling system by the year 2070, and the results are decay corrected to the year 2070 . 
Table 4.18. Inventory Introduced by Surrogate Rules (decay corrected to 2070)

\begin{tabular}{|c|c|c|c|}
\hline Analyte & $\begin{array}{l}\text { Surrogate Data } \\
\text { (Ci) }\end{array}$ & Percent Surrogate & $\begin{array}{l}\text { Total } \\
\text { (Ci) }\end{array}$ \\
\hline Tritium & $2.7200 \mathrm{E}+01$ & $0.10 \%$ & $2.7502 \mathrm{E}+04$ \\
\hline Carbon-14 & $4.0957 \mathrm{E}+01$ & $0.07 \%$ & $5.6325 \mathrm{E}+04$ \\
\hline Chlorine-36 & 0 & $0 \%$ & $3.4838 \mathrm{E}+02$ \\
\hline Selenium-79 & $7.7633 \mathrm{E}-03$ & $0.00 \%$ & $1.8487 \mathrm{E}+02$ \\
\hline Strontium-90 & $1.8856 \mathrm{E}+03$ & $0.01 \%$ & $1.5375 \mathrm{E}+07$ \\
\hline Technetium-99 & $3.9104 \mathrm{E}+00$ & $0.01 \%$ & $3.1321 \mathrm{E}+04$ \\
\hline Iodine-129 & $8.7511 \mathrm{E}-03$ & $0.01 \%$ & $6.5513 \mathrm{E}+01$ \\
\hline Cesium-137 & $2.5387 \mathrm{E}+03$ & $0.01 \%$ & $2.2977 \mathrm{E}+07$ \\
\hline Europium-152 & $5.6700 \mathrm{E}+00$ & $4.61 \%$ & $1.2288 \mathrm{E}+02$ \\
\hline Uranium-233 & $1.3628 \mathrm{E}+00$ & $0.14 \%$ & $9.5441 \mathrm{E}+02$ \\
\hline Uranium-235 & $2.6026 \mathrm{E}-01$ & $0.24 \%$ & $1.0960 \mathrm{E}+02$ \\
\hline Neptunium-237 & $8.1976 \mathrm{E}-03$ & $0.00 \%$ & $2.7366 \mathrm{E}+02$ \\
\hline Uranium-234/238 (a) & $1.2274 \mathrm{E}+01$ & $0.22 \%$ & $5.6295 \mathrm{E}+03$ \\
\hline \multicolumn{4}{|c|}{$\begin{array}{l}\text { (a) Within the System Assessment Capability (SAC), the combined curies of } \\
\text { uranium- } 234 \text { and uranium-238 are modeled as a single analyte because (1) both } \\
\text { isotopes are in the uranium series decay chain, (2) their impacts on human health } \\
\text { and the ecology can be addressed using the isotopic ratio between the two and } \\
\text { their combined curies, and (3) modeling them as one analyte instead of two cuts } \\
\text { the cost of their simulation in half. }\end{array}$} \\
\hline
\end{tabular}




\subsection{Inventory Estimates}

This section describes the sources of inventory data and information that are the basis for the assembled inventory. The original files and any cited derivatives related to each topic discussed in the following sections are archived and maintained on the SAC share, a computer repository of information maintained by PNNL about the project. 'SAC share' refers to the SAC Windows File server at Ilsac.pnl.gov $S$ Sharel, and archived inventory subdirectories and files are found under $\backslash$ data\rev.1 $\backslash$ inventory\. The assembly of inventory data occurred over a multiyear period. Much of the data were received initially in FY 2000 and 2001, and then updated by adding recent or additional record data. To assemble the inventory for some wastes and waste sites, one enters data files into the inventory database in their chronological order, and follows the instructions to edit, delete, and append data in the inventory database. To duplicate some inventories in the inventory database (e.g., solid waste burial grounds), it would be necessary to duplicate the original sequence of data entries. Section 7 on Quality Assurance describes in more detail the file archival and maintenance process for inventory data, and the configuration management of inventory files supporting Hanford assessments.

\subsection{Tank Inventory}

Inventories associated with the future disposition of today's single- and double-shell tank waste are estimated by the HTWOS (Kirkbride et al. 2005), which was described briefly in Section 3.1. This model of future tank waste disposition relies on an understanding of the tank waste inventory and the processes that will be used to retrieve the waste from the tanks, separate it into high-level and low-activity fractions, and vitrify it into a glass product. The HTWOS model provides estimates of the primary waste form and secondary waste stream inventories. A separate estimate of primary and secondary waste form volumes has been produced and utilized in conjunction with the HTWOS model results (see Appendix A in Puigh and Wood 2005). In addition to the primary waste forms and secondary waste streams, the HTWOS model provides an estimate of the tank residual for each tank and an estimate of tank retrieval loss composition. However, DOE's best estimate is that sufficient control exists on tank waste retrieval operations to ensure that no tank waste retrieval losses will occur to the vadose zone underlying single-shell tanks. High-pressure jet breakup and dissolution methods for tank waste retrieval will only be used in single-shell tanks that have not exhibited past leaks. A method involving less force will be used in those tanks that have exhibited past leaks. Accordingly, the Hanford assessment inventory described herein assumes there are no tank waste retrieval losses to the vadose zone during tank waste recovery operations for 149 single-shell tanks.

Original files provided from the HTWOS model run employed in the analysis are archived on the SAC share at \data\rev.1 1 inventory\HTWOS_30-Aug-05 in the zip file 'in.yearly-files-bd.zip,' and the resulting input file is located on the SAC share at \data $\mid$ rev.1 1 inventory $\backslash$ HTWOS_30-Aug-05\Add_Pu $\backslash$, file 'HTWOS_TDP.csv.'

\subsection{Planned and Unplanned Liquid Releases}

The substantial liquid discharges and unplanned releases on the Central Plateau are simulated using the Hanford SIM (Corbin et al. 2005), which was briefly described in Section 3.2. This model is a combination of process knowledge, waste transfer records, estimates of waste stream compositions, and 
estimates of spent fuel inventories processed on the Central Plateau. The model run employed was provided on April 13, 2005, with an amendment to the release inventory at $216-\mathrm{B}-7 \mathrm{~A} \% \mathrm{~B}^{11}$ provided on June 15, 2005. The methods and files associated with this run of the SIM are documented in Corbin et al. (2005), and the original files provided from the Hanford SIM run employed in the analysis are archived on the SAC share at datałrev.1 inventory $\backslash$ SIM_25-Aug-05 as files 'SAC-Section1.xls' through 'SAC-Section6.xls,' and the resulting input file is located on the SAC share at \data \rev.1 \inventory $\backslash$ SIM_25-Aug-05\Add_Am243\, file 'Combined_SIM_for_database.csv.' Note that the files provided the project in April and June 2005 are statistically the same as those published in September 2005.

Liquid discharge sites and unplanned releases other than those included in the Hanford SIM results are accounted for using published records of planned discharges and unplanned releases (e.g., Diediker 1999; Stenner et al. 1988; Maxfield 1979; Anderson 1976). This includes some waste sites in the 100 and 300 Areas. In most cases, published reports provide a cumulative decay-corrected inventory estimate for a single moment in time. This activity or mass inventory information was supplemented with information on the years of active discharge operations at a site to generate an estimate of the annual releases to the vadose zone. Maxfield (1979) provided information on all 200 Area engineered disposals and unplanned releases at waste sites on the Central Plateau. Stenner et al. (1988) assembled information on each of the proposed CERCLA waste sites on the Hanford Site including 100 and 300 Areas. Diediker (1999) provides a summary of cumulative release at 100 and 200 Area liquid waste disposal sites that had not been remediated by 1999. In his 1976 document, Anderson provides annual discharge and radioactive waste inventory data on waste sites on the Central Plateau. The final data sets for liquid discharge sites and unplanned releases based on these data were developed by Fluor Hanford, Inc. staff and provided to the Characterization of Systems Project.

Original files associated with liquid discharges and unplanned release sites that are not modeled by the Hanford SIM and are employed in the analysis are archived on the SAC share in various directories under \data \rev.1 \inventory $\backslash$ Other Inventory Datasets\. The subdirectories and filenames associated with these data are presented in Table 5.1.

\subsection{Fuel Element Failures}

Fuel element failures occurred in the single-pass graphite core production reactors at the Hanford Site. These failures gave rise to contaminated reactor cooling water being released to the environment. The total inventory by radionuclide for fuel element failures in the single-pass reactors was developed for the Hanford Environmental Dose Reconstruction (HEDR) Project by BA Napier (Napier 1991), and was received as an Excel file Fuel failure.xls, dated March 22, 2000, from BA Napier. ${ }^{12}$ This file contains inventory for 45 constituents, including the following radionuclides of potential interest to Hanford assessments: tritium, carbon-14, chlorine-36, selenium-79, strontium-90, technetium-99, iodine-129, cesium-137, uranium-234, uranium-235, uranium-236, neptunium-237, uranium-238, plutonium-239/240, americium-241, plutonium-241, and plutonium-242.

\footnotetext{
${ }^{11}$ The UNIX-based computer system prohibits the use of ' $\&$;' therefore, the notation ' $\%$ ' was used instead. Other places use the more familiar notation 216-B-7A\&B. '216-B-7A\%B' is the waste site name used in the analysis.

${ }^{12}$ Napier, BA (Pacific Northwest National Laboratory, Richland, Washington). March 23, 2003, e-mail to RL Aaberg (Pacific Northwest National Laboratory, Richland, Washington). Subject: Fuel Failures with attached file 'Fuel Failure.xls' (file dated $3 / 22 / 2000)$.
} 
Table 5.1. Data Files for Liquid Discharge and Unplanned Release Sites not Modeled by the Hanford SIM

\begin{tabular}{|c|c|c|c|}
\hline $\begin{array}{l}\text { Miscellaneous Liquid } \\
\text { Data Sets }\end{array}$ & Subdirectory ${ }^{(a)}$ & Filename & Edited Input Filename \\
\hline $\begin{array}{l}\text { clean-discharge_2005-11- } \\
\text { 02_DCR-0020.csv }\end{array}$ & $\begin{array}{l}\text { Clean_Discharges_Rev05 } \\
0605\end{array}$ & Clean-discharges_initial.csv & Clean-discharges_review.xls \\
\hline dp07 & DP07 & dp07.xls & dp07.xls \\
\hline dp21 & dp21 & dp21.xls & dp21.xls \\
\hline dpa4[0] & dpa4 & dpa4[0]AppA.doc; db4.mdb & dpa4[0]AppArla.doc; db4.mdb \\
\hline dpa9/2003 & dpa9 & dpa9[0]B.doc; dpa9.mdb & dpa9[0]B-rla.doc; dpa9.mdb \\
\hline FMC_e_5-03-01 & $\begin{array}{l}\text { 05_INVENTORY_DP } \\
\text { Doc } \backslash F Y 2000-2001\end{array}$ & FMC_e_5-03-01.rtf & $\mathrm{NA}^{(\mathrm{b})}$ \\
\hline Sac0_1908_NE & Sac0_1908_NE & Sac0_1908_NE.xls & Sac0_1908_NE.xls \\
\hline sac0_liq_r00 & sac0_liq_r00 & sac0_liq_r00.xls & sac0_liq_r00.xls \\
\hline sac0_liq_r01 & sac0_liq_r01 & sac0_liq_r01.xls & sac0_liq_r01.xls \\
\hline sac0_liq_r05 & sac0_liq_r05 & sac0_liq_r05.xls & sac0_liq_r05.xls \\
\hline sac0_liq_r11 & sac0_liq_r11 & sac0_liq_r11.xls & sac0_liq_r11.xls \\
\hline sac0_misc_r00 & sac0_misc_r00 & sac0_misc_r00.xls & sac0_misc_r00.xls \\
\hline sac0_river_r00 & sac0_river_r00 & sac0_river_r00.xls & sac0_river_r00.xls \\
\hline sac0_upr_r04 & sac0_upr_r04 & sac0_upr_r04.xls & sac0_upr_r04.xls \\
\hline $\begin{array}{l}\text { Sac0_upr_r04_WIDS_1-17- } \\
01\end{array}$ & $\begin{array}{l}\text { Sac0_upr_r04_WIDS_1- } \\
17-01\end{array}$ & Sac0_upr_r04_WIDS.xls & Sac0_upr_r04_WIDS.xls \\
\hline SALDS_ctk_June_2005 & SALDS_ctk_June_2005 & $\begin{array}{l}\text { SALDS_discharge\%inventor } \\
\text { y_ctk_June_2005.xls }\end{array}$ & $\begin{array}{l}\text { SALDS_discharge\%inventory_ct } \\
\text { k_June_2005.xls }\end{array}$ \\
\hline $\begin{array}{l}\text { (a) Subdirectory under } \backslash \text { da } \\
\text { (b) NA = Not applicable; }\end{array}$ & inventory $\backslash$ Othe & $\begin{array}{l}\text { Datasets. } \\
\text { Coony. }\end{array}$ & \\
\hline
\end{tabular}

The total inventory was divided among the fuel element failures which occurred during the operating history of each reactor, apportioned by fraction released by reactor and year. A history of fuel ruptures (Gydesen 1993) contains a description of each rupture (for example, jacket split). Another HEDR document (Heeb and Bates 1994) classifies these fuel element failures on a scale of 1 to 6 and estimates the magnitude of fuel dissolution for each. The authors of this report obtained a data file (STRRMrup.625), containing most of the rupture information from Gydesen, from CM Heeb on January 16,$2003 ;{ }^{13}$ the file was compared and cross-checked with the Gydesen document. The rupture descriptions were merged into three classes, as shown in Table 5.2.

Each rupture event was weighted by the severity of the failure class, shown in the third column of Table 5.2: Class 1 was given a weighting factor of 4; Class 2, a factor of 2; and Class 3 was unweighted. Weighted subtotals and fraction of total inventory released were calculated for each reactor and year.

Disposal of effluent was assigned to either the Columbia River or to trench disposal, based on descriptions of past disposal and discharge operation as summarized in a personal communication. ${ }^{14}$ Original files associated with fuel element failures, employed in the analysis are archived on the SAC

\footnotetext{
${ }^{13}$ Heeb, CM (retired from Pacific Northwest National Laboratory, Richland, Washington). January 16, 2003, e-mail to RL Aaberg (Pacific Northwest National Laboratory, Richland, Washington). Subject: Rupture File with attached file named 'strrmrup.625.'

${ }^{14}$ Kincaid CT (Pacific Northwest National Laboratory, Richland, Washington). 2003. Personal communication to RL Aaberg and FM Coony, "Treatment of Fuel Failure Events; Fractions to Assign to the Columbia River and to the Basin/Trench Disposal," April 1, 2003.
} 
share at $\backslash$ data $\backslash$ rev.1 $\backslash$ inventory $\backslash$ Other Inventory Datasets $\backslash F F \_d p \backslash$ under filename 'FF_DataPackage.xls.' The fuel failure data package provides an estimate of the radionuclides released by rupture of production reactor fuel elements by reactor and year.

Table 5.2. Classification of Fuel Element Ruptures

\begin{tabular}{||l|l|c||}
\hline $\begin{array}{c}\text { Severity } \\
\text { Class (1-3) }\end{array}$ & \multicolumn{1}{|c||}{ Original Classification $^{(\text {a) }}$} & Weighting \\
\hline \hline 1 Worst & Disintegration, complete dissolution of fuel & 4 \\
\hline 2 Severe & $\begin{array}{l}\text { Cleavage, uranium split, split, split transverse, jacket split, side and cap, } \\
\text { split longitudinal, can split }\end{array}$ & 2 \\
\hline 3 All other & $\begin{array}{l}\text { Includes Class 3 medium (cap, cap end, etc), Class 4 low (side, side tear, } \\
\text { side other, side groove, etc) class 5 I\&E Hole (hole, inside other), and class } \\
\text { 6, all others. }\end{array}$ & 1 \\
\hline (a) Description from Gydesen (1993); Class 1 through 6 from Heeb and Bates (1994). \\
\hline
\end{tabular}

\subsection{Reactor Cores}

Inventories of the graphite cores are taken from the Draft Environmental Impact Statement on Decommissioning Eight Surplus Production Reactors (DOE 1989). Appendix A of that document contains a description of the single-pass production reactors including their locations, physical size, and radiological characteristics. Inventories are provided for each single-pass production reactor. The inventories are itemized for each reactor's graphite stack, thermal shield, process tubes, control system, bio-shield, and storage basin. A similar inventory for the $\mathrm{N}$ Reactor is provided by memo from the DOE program. $^{15}$

Original files associated with graphite cores of production reactors, employed in the analysis are archived on the SAC share at \data\rev.1 $\backslash$ inventory $\backslash$ Other Inventory Datasets $\backslash$ Hcores_ctk_052505\under filename 'Hcores_25 May 2005.xls.'

\subsection{Solid Waste Disposals}

Records of past solid waste disposals and forecasts of future solid waste disposals are the responsibility of Fluor Hanford, Inc., the Project Hanford Management Contractor. Beginning in 2000, Fluor Hanford, Inc. provided the record of solid waste disposals based on the SWITS database. Initially, Fluor Hanford, Inc. provided the record of disposals from 1944 until September 1999. In 2005, Fluor Hanford, Inc. updated the files to include disposal records through September 2004. Also in 2005, using the SWIFT, Fluor Hanford, Inc. provided the Characterization of Systems Project a forecast of future solid waste disposals including onsite and offsite generators of low-level radioactive waste. In addition to annual entries for each burial ground, these disposals are formatted to reveal (1) onsite versus offsite contributions; (2) category 1 low-level waste, category 3 low-level waste, mixed low-level waste, GTC3, versus transuranic waste; and (3) waste of tank farm origin versus other onsite sources.

\footnotetext{
${ }^{15}$ Day RS (Hanford Site Environmental Restoration Contractor, Richland, Washington). February 11, 1997. ERC Team Interoffice Memorandum \#042809 from RS Day to VG Edens. Subject: $105 N$ and 107N Hazards Assessment (Inventories. Environmental Restoration Contractor, Richland, Washington.
} 
Original files associated with solid waste records and projections, employed in the analysis are archived on the SAC share in various directories under \data \rev.1 \inventory\Other Inventory Datasets\. The subdirectories and filenames associated with these data are presented in Table 5.3.

Table 5.3. Data Files for Solid Waste Input Data

\begin{tabular}{|c|c|c|c|}
\hline Solid Waste Data Set & Subdirectory ${ }^{(a)}$ & Filename & Edited Input Filename \\
\hline dp05 & dp05 & dp05.doc & dp05.doc \\
\hline dp07 & DP07 & dp07.xls & dp07.xls \\
\hline dp14 & dp14 & dp14.xls & dp14.xls \\
\hline $\mathrm{dp} 20 / \mathrm{db} 05 \mathrm{r}$ & dp20_db05r & DP20.doc; db05r.mdb & DP20.doc; db05r.mdb \\
\hline dpa3[0]_2/20/03 & dpa3[0] & dpa3[0].doc; dpa3.mdb & dpa3.mdb \\
\hline dpa4[0] & dpa4 & dpa4[0]AppA.doc & dpa4[0]AppArla.doc \\
\hline $\mathrm{dpaB}[0] / 2004$ & dpaB & dpaB[0]A.xls & dpaB(0)A_edt.xls \\
\hline $\mathrm{dpaC}[0] / 2003$ & $\mathrm{dpaC}[0] 2003$ & dpC $[0]$ import.xls & dpaC(0)import.xls \\
\hline dpaC[1]_5/2004 & $\mathrm{dpaC}(1) \_5 \_2004$ & dpaC[1].xls & $\mathrm{dpaC}(1) \cdot \mathrm{xls}$ \\
\hline $\mathrm{dpaD} / 2004$ & DpaD_2004 & $\mathrm{DPaD}[0] \mathrm{A} . \mathrm{xls}$ & DPaD(0)A_FY2005.xls \\
\hline DpaD[0]/2003 & $\mathrm{dpaD}(0) 2003$ & $\begin{array}{l}\text { dpaD[0]F.xls; } \\
\text { dpaD[0]G.xls }\end{array}$ & dpaD(0)all_input.xls \\
\hline DpaG 0/2004 & dpaG 0_2004 & $\mathrm{DPaG}[0] \mathrm{A} . \mathrm{xls}$ & DPaG_TableA.xls \\
\hline $\operatorname{DpaG[1]~01/2005}$ & $\mathrm{dpaG}[1] 2005$ & DPaG[1]A.xls & DPaG[1]A.xls \\
\hline dpaJ_2/2004 & dpaJ_2_2004 & dpaJ $[0] . d o c$ & dpaJ.xls \\
\hline dpaN_5/2004 & dpaN_5_2004 & $\mathrm{DPaN}[0] \mathrm{A} . \mathrm{xls}$ & $\operatorname{DPaN}(0) \cdot x l s$ \\
\hline $\mathrm{dpaQ}$ & $\begin{array}{l}\text { 05_INVENTORY_DP_Doc } \\
\text { FY2005\Coony-datalDpaQ }\end{array}$ & dpaQ[0].xls & dpaQ0.xls \\
\hline $\mathrm{dpaR} / 2005$ & dpaR_2005 & DPaR[0]A.xls & DPaR_input.xls \\
\hline $\mathrm{dpaS} / 2005$ & dpaS_2005 & DPaS[A].xls & DPaS(0)A_edt.xls \\
\hline dpaT/2005 & DpaT_2005 & DPaT[0]A.xls & DPaT_data.xls \\
\hline $\mathrm{dpaU} / 2005$ & dpaU_2005 & DPaU[0]A.xls & DPaU(0)A_edt.xls \\
\hline DPaX(0)A_23_June_2005 & DPaX(0)A_23_June_2005 & $\begin{array}{l}\text { DPaX[0]A_22 June } \\
\text { 2005.xls }\end{array}$ & $\begin{array}{l}\text { DPaX[0]A_22 June } \\
\text { 2005.xls }\end{array}$ \\
\hline $\mathrm{dpaY} / 2005$ & dpaY_2005 & DPaY[0]A.doc & dpaY.xls \\
\hline FMC_e_2-23-01 & FMC_e_2-23-01 & FMC_e_2-23-01.rtf & $\mathrm{NA}^{(\mathrm{b})}$ \\
\hline PWE_e_6-07-05 & PWE_e_6-07-05 & PWE_e_6-07-05.rtf & $\begin{array}{l}\text { NA }{ }^{(c)} \text { PWE_e_6-07- } \\
\text { 05.rtf }\end{array}$ \\
\hline rla_add_083105 & rla_add_8-31-2005 & SRC_Add_Zeros.xls & SRC_Add_Zeros.xls \\
\hline SAC_Updates_9-23-03 & SAC_Updates_9-23-03 & $\begin{array}{l}\text { SAC_Updates_9-23- } \\
\text { 03.xls }\end{array}$ & $\mathrm{NA}^{(\mathrm{d})}$ \\
\hline \multicolumn{4}{|c|}{$\begin{array}{l}\text { (a) Subdirectory under \data|rev. } 1 \text { inventory } \backslash \text { Other Inventory Datasets } \backslash \text { dat } \\
\text { (b) NA = Not applicable; dataset refers to an e-mail from FM Coony. } \\
\text { (c) NA = Not applicable; dataset refers to an e-mail from PW Eslinger. } \\
\text { (d) NA = Changed air volume for B_Plant_Filter to filter media volume. }\end{array}$} \\
\hline
\end{tabular}


In the interest of using fully consistent inventories and releases to the water table in a suite of analyses, the Hanford Site Configuration Management Board requested that the Hanford Remediation Assessment Project include as an option use of the same inventory release to the water table presented in the IDF performance assessment (Puigh and Wood 2005). ${ }^{16}$ These releases to the water table are referred to as third-party releases and they are furnished by Fluor Federal Services. The IDF would not receive waste for several months to years; therefore, its operation lies in the forecast period originally provided by the HTWOS model simulation of tank waste and the forecast of other Hanford and offsite generator disposals in Hanford Site solid waste disposal facilities. The HTWOS model simulation included disposal of immobilized low-activity waste, bulk vitrification product from a supplemental technology, and secondary waste streams of all tank waste processing. The HTWOS model results are identical in both analyses, that is (1) in this assembled inventory, and (2) in the third-party releases provided by Fluor Federal Services. In analyses using the IDF performance assessment inventory, (that is, the third-party releases), IDF performance assessment analyst files containing an estimate of future IDF disposals supersede the files assembled in this effort. As mentioned above, the two forecasts are identical with regard to the tank waste inventories because they both rely on a single HTWOS model simulation (Kirkbride et al. 2005) and the same BBI. However, they differ slightly in the forecast of waste from other Hanford and offsite generators because the IDF performance assessment relied on an earlier SWIFT data set (Barcot 2003) for Hanford approved solid waste generators and an estimate of other potential solid waste sources based on Fritz et al (2003). Because the inventories are not identical, use of thirdparty releases has the potential to introduce a mass balance discrepancy between alternate case studies performed using the SAC tool. Note that the third-party releases provided by Fluor Federal Services for release to the water table from IDF only relate to IDF operation. All prior DOE solid waste disposals are made to low-level waste burial grounds.

To assure traceability, the IDF performance assessment releases provided by Fluor Federal Services are treated as a data set like others in SAC, subject to the requirements of the Hanford Remediation Assessment Project Data Configuration Management \& Verification Plan. Upon receipt, the third-party releases are prepared and managed as an Electronic Data Transfer Package (EDTP). These are stored in a Data Configuration Item location on the SAC Windows File server at IIsac.pnl.govlShareldata\rev.1\3rdParty.releases.

\subsection{US Ecology - Commercial Low-Level Waste}

The Washington State Departments of Health and Ecology jointly issued a final environmental impact statement for the commercial low-level radioactive waste disposal site located at Richland, Washington (Washington State 2004). The EIS contains estimates of past disposal inventories over periods of time, (e.g., 1965-1981, 1982-1987), as well as estimates of future disposal inventory through the facility's operational life (e.g., 2056). Annual inventories were estimated based on the annual waste volumes reported in the environmental impact statement. The development of annual inventories was completed with the assistance of Andrew Thatcher, Washington State Department of Health, Olympia, Washington.

Original files associated with US Ecology commercial low-level radioactive waste, employed in the analysis are archived on the SAC share at $\backslash$ data $\backslash$ rev. 1 inventory $\backslash$ Other Inventory Datasets $\backslash$

'US_Ecology_ctk_050205\under filename 'REV1sourceterm_ctk_2-May-2005_rev4 with AHT input.xls.'

\footnotetext{
${ }^{16}$ The Integrated Disposal Facility in the 200 East Area is a proposed facility pending publication of the record of decision for the Tank Closure and Waste Management Environmental Impact Statement, which will decide whether and where it would exist.
} 


\subsection{Spent Nuclear Fuel}

Records of spent nuclear fuel inventory are the responsibility of Fluor Hanford, Inc. the Project Hanford Management Contractor. Accordingly, Fluor Hanford, Inc. provided the spent nuclear fuel inventories to the Characterization of Systems Project. Spent nuclear fuel is not considered waste when generated, and the majority of spent nuclear fuel is never disposed to or released into the vadose zone environment. It is included in this analysis of inventory to enable a mass balance including the export of spent nuclear fuel. When spent nuclear fuel is staged for export from Hanford, (e.g., retrieved from $\mathrm{K}$ Basins and stored in the canister storage building prior to shipment offsite), it is assumed to be waste and is included in the inventory analysis. Thus, for the purposes of assembling Hanford inventories for spent nuclear fuel, they are assembled beginning with the year it was, or, is assumed to be, declared waste, (i.e., not when it was created in a reactor). This inventory includes K Basin spent nuclear fuel (Packer 1999; Reilly 1998), Shippingport spent nuclear fuel (Wittekind et al. 1999), FFTF spent nuclear fuel (Bergsman 1994), as well as some spent fuel used in research now disposed in solid waste burial grounds (Bergsman 1994). Inventories of sludge in the K Basins are taken from Pearce (2000). Actual transactions are taken from DOE (2005c), and proposed schedules for shipment to offsite disposal are from DOE (1998a) and Ecology et al. (1989).

Original files associated with spent nuclear fuel, employed in the analysis are archived on the SAC share in various directories under $\backslash$ data $\backslash$ rev. $1 \backslash$ inventory $\backslash$ Other Inventory Datasets. The subdirectories and filenames associated with these data are presented in Table 5.4.

Table 5.4. Data Files for Spent Fuel Data

\begin{tabular}{|l|l|l|l||}
\hline \multicolumn{1}{|c|}{ Data Set } & \multicolumn{1}{|c|}{ Subdirectory $^{(\text {a) }}$} & \multicolumn{1}{|c||}{ Filename } & \multicolumn{1}{|c||}{ Edited Input Filename } \\
\hline \hline dp03 & dp03 & dp03.xls & dp03.xls \\
\hline DP18 & DP18 & dp18.doc & DP18_add.xls \\
\hline dpa6[1]/2005 & dpa6 & DPa6[1]A.xls & DPa6(1)A_edt.xls \\
\hline dpaP5/2004 & dpaP5_2004 & DPaP[0].xls & DPaP(0).xls \\
\hline sac0_sf_r00 & Sac0_sf_r00 & Sac0_sf_r00.xls & Sac0_sf_r00.xls \\
\hline (a) Subdirectory under $\backslash$ data|rev.1 $\backslash$ inventorylOther Inventory Datasets. \\
\hline
\end{tabular}

\subsection{Special Nuclear Materials}

Inventories of the special nuclear material presented for the Plutonium Finishing Plant are from the final environmental impact statement on the stabilization of that facility (DOE 1996). Both the baseline inventory of material in the facility and an assumed $10 \%$ holdup or retention of that material is available in the environmental impact statement (DOE 1989). Additional information on special nuclear materials at the Hanford Site including tritium, uranium, and plutonium inventories was published by Fluor Hanford, Inc. (FHI 2001). A summary of information on losses during tritium production at Hanford can be found in Section 7 of Heeb and Gydesen (1994) and this topic is further described in Appendix D.

Original files associated with special nuclear material, employed in the analysis are archived on the SAC share at \data $\backslash$ rev. $1 \backslash$ inventory $\backslash$ Other Inventory Datasets $\backslash$ Sac0_misc_r01 $\backslash$ under filename 'Sac0_misc_r01.xls.' 


\subsection{Cesium/Strontium Capsules and WESF}

The inventory of cesium-137 and strontium-90 contained in capsules stored in the Waste Encapsulation and Storage Facility (WESF) has been estimated from data and information provided in the WESF Safety Analysis report (Covey 2004), a CH2M HILL Hanford Group, Inc. interoffice memorandum ${ }^{17}$ and information provided by Pennock ${ }^{18}$ and Holten. ${ }^{19}$ The estimate was cross checked against data provided in the engineering support document for the Hanford defense waste environmental impact statement (RHO 1985). An additional inventory of residue within the WESF, especially the hot cells, was taken from the safety analysis report (Covey 2004).

Original files associated with cesium/strontium capsules and WESF employed in the analysis are archived on the SAC share at \data\rev.1 \inventory $\backslash$ Other Inventory Datasets $\backslash$ CS-SR_ctk_051605 $\backslash$ under filename 'Cs-Sr inventories in WESF_21-April-2005.xls.'

\subsection{Fast Flux Test Facility (FFTF)}

Inventories associated with buildings within the Fast Flux Test Facility (FFTF) complex have been taken from the technical information document supporting the ongoing environmental impact analysis for closure of the facility (York 2005). This document includes a risk assessment and supporting data (Clark et al. 2003) for the FFTF completed in August 2003 prior to issuance of the technical information document.

Original files associated with FFTF employed in the analysis are archived on the SAC share at

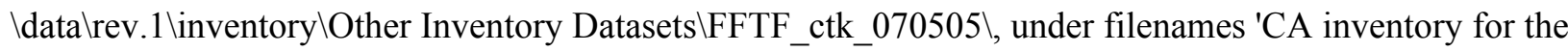
Fast Flux Test Facility_30 May 2005.doc' and 'FFTF_INV_05-30-05.xls.'

\subsection{Atmospheric Releases}

The basis for the collected atmospheric releases from the separations plants is, in part, data from the HEDR (Napier 1992). The basis for collected carbon-14 atmospheric releases from the reactors is a method described in Section 5.2 of a HEDR report (Heeb 1994). In this method, the average daily carbon-14 release value is generated using two historical reports. The annual release of carbon-14 for each of the eight single-pass production reactors from Anderson (1958) is $(0.1 \div 8$ reactors $) \mathrm{Ci} /$ day. This release is applied from start up of reactor operations through 1959. The assumed number of days per year is 365. The annual release of carbon-14 from McConnon (1962) for each reactor is $(0.127 \div 8$ reactors) $\mathrm{Ci} /$ day. This annual release is applied from 1960 through 1971. The assumed number of days per year is 365. The release values are applied for the operating months per year of each reactor. The data from the HEDR Project do not contain data for the later period, e.g., after 1972. For this later period, some inventory data for the separations plants has been assembled from monitoring reports. These annual reports are listed in Table 5.5.

\footnotetext{
${ }^{17}$ CH2M HILL Hanford Group, Inc. Interoffice Memo from BA Higley to TM Horner, dated April 30, 2003; Subject: Hanford Material Balance for Strontium-90 and Cesium-137.

${ }^{18}$ Pennock, JA (company, Richland, Washington). May 16, 2005, e-mail to CT Kincaid (Pacific Northwest National Laboratory, Richland, Washington); Subject: RE: Cs-Sr inventories in WESF.

${ }^{19}$ Holten, RA (DOE/RL, Richland, Washington). May 26, 2005, e-mail to ME Burandt (DOE/ORP, Richland, Washington); Subject: Re: Your request for validation of TC-EIS assumptions related to RL.
} 
Table 5.5. Reference List of Reports Including Atmospheric Releases

\begin{tabular}{||l|l||}
\hline \multicolumn{1}{|c|}{ Year-Effluent Release } & \multicolumn{1}{|c||}{ Report Reference - Author(s), Date } \\
\hline \hline $1944-1972$ & DSHS (1987) \\
\hline 1973 & Nees and Corley (1974a, 1974b) \\
\hline 1974 & Fix (1975); Fix and Blumer (1975) \\
\hline 1975 & Speer, Fix, and Blumer (1976) \\
\hline 1976 & Fix, Blumer Hoenes, and Bramson (1977) \\
\hline 1977 & Houston and Blumer (1978) \\
\hline 1978 & Houston and Blumer (1979) \\
\hline 1979 & Houston and Blumer (1980) \\
\hline 1980 & Sula and Blumer (1981) \\
\hline 1981 & Sula, McCormack, Dirkes, Price, and Eddy (1982) \\
\hline 1982 & Sula, Carlile, Price, and McCarmack (1983) \\
\hline 1983 & Price, Carlile, Dirkes, and Trevathan (1984) \\
\hline 1984 & Price, Carlile, Dirkes, Jaquish, Trevathan, and Woodruff (1985) \\
\hline 1985 & Price, Carlile, Dirkes, Jaquish, Trevathan, and Woodruff (1986) \\
\hline 1985, Supplement & Price (1986) \\
\hline 1986 & PNL (1987) \\
\hline 1987 & Jaquish and Mitchell (1988) \\
\hline 1988 & Jaquish and Bryce (1989) \\
\hline 1989 & Jaquish and Bryce (1990) \\
\hline 1990 & Woodruff, Hanf, Hefty, and Lundgren (1991) \\
\hline 1991 & Woodruff, Hanf, and Lundgren (1992) \\
\hline 1992 & Woodruff, Hanf, and Lundgren (1993) \\
\hline 1993 & Dirkes, Hanf, Woodruff, and Lundgren (1994) \\
\hline 1994 & Dirkes and Hanf (1995) \\
\hline 1995 & Dirkes and Hanf (1996) \\
\hline 1996 & Dirkes and Hanf (1997) \\
\hline
\end{tabular}

Original files associated with atmospheric releases are archived on the SAC share, and are listed in Table 5.6.

Table 5.6. Data Files for Atmospheric Release Data

\begin{tabular}{||l|l|l|l||}
\hline \multicolumn{1}{|c|}{ Data Set } & \multicolumn{1}{|c|}{ Subdirectory $^{(\text {a) }}$} & \multicolumn{1}{c|}{ Filename } & \multicolumn{1}{c||}{ Edited Input Filename } \\
\hline \hline dp07 & DP07 & dp07.xls & dp07.xls \\
\hline DPa7/2003 & dpa7 & dpa7[1].doc; dpa7.mdb; & dpa7[1].doc; dpa7.mdb; \\
\hline Sac0_air_r00 & Sac0_air_r00 & Sac0_air_r00.xls & Sac0_air_r00.xls \\
\hline Sac0_air_r01 & Sac0_air_r01 & Sac0_air_r01.xls & Sac0_air_r01.xls \\
\hline $\begin{array}{l}\text { TBM - Duplicate of 1989 } \\
\text { data }\end{array}$ & $\begin{array}{l}\text { TBM - Duplicate of 1989 } \\
\text { data }\end{array}$ & $\begin{array}{l}\text { Dataset TBM.doc; FW } \\
\text { Release of C14.htm }\end{array}$ & N/A \\
\hline (a) Subdirectory under $\backslash$ datalrev.1 inventorylOther Inventory Datasets. \\
\hline
\end{tabular}




\subsection{Facilities including Canyons, Tunnels, Stacks, and Filters}

Inventories in facilities have been estimated using safety analysis and other similar reports developed as facilities transitioned from operations to decontamination and decommissioning (D\&D) activities. Data and information sources for facilities are summarized in Table 5.7. The available information does not distinguish between before and after D\&D activities. A portion of current facility inventories could be included in the SWIFT forecast of solid waste disposals. Hence, there is potential for double counting some of the facilities inventory.

Table 5.7. Reference List of Reports Including Facility and Allied Structure Inventories

\begin{tabular}{|c|c|c|}
\hline $\begin{array}{l}\text { Facilities and } \\
\text { Allied } \\
\text { Structures }\end{array}$ & $\begin{array}{l}\text { Report Reference - } \\
\text { Author(s), Date }\end{array}$ & Title and Document Number \\
\hline B Plant & DK Smith (1998) & $\begin{array}{l}\text { Closeout of End Point 00.00.26, Remaining Hazardous } \\
\text { Substances/Dangerous Waste Documentation, File } \\
\text { No. 16D00-98-DKS-078 }\end{array}$ \\
\hline B Plant & FM Simmons (1999) & $\begin{array}{l}\text { Documentation of Remaining Hazardous Substances / } \\
\text { Dangerous Wastes in B Plant, HNF-3208, Rev. 0A }\end{array}$ \\
\hline B Plant & BA Schwehr (1999) & $\begin{array}{l}\text { B Plant Surveillance and Maintenance Phase Safety Analysis } \\
\text { Report, HNF-3358, Rev. } 0\end{array}$ \\
\hline U Plant & $\begin{array}{l}\text { H\&R Technical Assoc. and } \\
\text { NR Kerr (2000) }\end{array}$ & U Plant Facility Safety Analysis Report, BHI-01157, Rev. 2 \\
\hline 224-B & NR Kerr (2000) & 224-B Facility Safety Analysis Report, BHI-01156, Rev. 0 \\
\hline REDOX Plant & $\begin{array}{l}\text { NR Kerr and H\&R } \\
\text { Technical Assoc, and MH } \\
\text { Chew \& Assoc. (2000) }\end{array}$ & $\begin{array}{l}\text { REDOX Facility Safety and Analysis Report, BHI-01142, } \\
\text { Rev. } 2\end{array}$ \\
\hline PUREX Plant & EN Dodd III (1999a) & $\begin{array}{l}\text { Plutonium Uranium Extraction (PUREX) End State Basis for } \\
\text { Interim Operation (BIO) for Surveillance and Maintenance, } \\
\text { HNF-SD-CP-ISB-004, Rev. } 0\end{array}$ \\
\hline PUREX Plant & EN Dodd III (1999b) & $\begin{array}{l}\text { PUREX Deactivated End-State Hazard Analysis, } \\
\text { HNF-SD-CP-HIE-004, Rev. } 0\end{array}$ \\
\hline PUREX Plant & J Reddick (1993) & $\begin{array}{l}\text { Estimate of PUREX Plant Inventory of Chemicals and } \\
\text { Radioactivity; Letter report from LATA, Inc. to } \\
\text { D Washenfelder, WHC. }\end{array}$ \\
\hline
\end{tabular}

Files associated with facilities are archived on the SAC share in various subdirectories, under $\backslash$ data $\backslash$ rev. $1 \backslash$ inventory $\backslash$ Other Inventory Datasets $\backslash$. The subdirectories and filenames associated with these data are presented in Table 5.8.

\subsection{Site Total Summary Including the Effect of Inventory Completion Rules}

A knowledge of the inventories in waste sites is the first step in evaluating potential long-term far-field impacts to man and the environment. Knowledge of the inventory today, prior to application of remedial actions, enables the study of potential impact of alternate remedial actions and even a no-action scenario. The assembled inventory includes data on a waste site, year, and analyte basis. Of the 1,052 waste sites identified for study, 690 have been assigned inventories of one or more analytes of 
interest. Information on the remaining waste sites was reviewed and they were determined to be (1) water sites discharging clean water, (2) waste sites within waste sites (i.e., unplanned releases within waste sites), (3) waste sites involving documented minimal releases or contaminants not of interest, or (4) duplicate event reporting. Note that inventory movement through remedial actions are simulated by SAC and are not reported in this inventory compilation. The SAC analysis begins in 1944 and, being part of the simulation, changes in inventory due to remedial actions are not presented as changes to the accumulated inventory shown here. For example, inventories in river corridor waste sites continue to be reported as being in those waste sites in the inventory. It is only during simulation that remedial actions are modeled and the CERCLA site inventories are moved to the ERDF trench in the Central Plateau of Hanford.

Table 5.8. Data Files for Facilities Data

\begin{tabular}{||l|l|l|l||}
\hline \multicolumn{1}{|c|}{ Data Set } & \multicolumn{1}{|c|}{ Subdirectory $^{(a)}$} & \multicolumn{1}{c|}{ Filename } & \multicolumn{1}{c||}{ Edited Input file } \\
\hline \hline Dp07 & DP07 & dp07.xls & dp07.xls \\
\hline Sac0_misc_r00 & Sac0_misc_r00 & Sac0_misc_r00.xls & Sac0_misc_r00.xls \\
\hline Sac0_misc r04 & Sac0_misc_r04 & Sac0_misc_04.xls & Sac0_misc_r04.xls \\
\hline Sac0_misc r05a & Sac0_misc_r05a & Sac0_misc_r05a.xls & Sac0_misc_r05a.xls \\
\hline Sac0_misc r06 & Sac0_misc_r06 & Sac0_misc_r06.xls & Sac0_misc_r06.xls \\
\hline Sac_updates_9-23-03 & SAC_Updates_9-23-03 & SAC_Updates_9-23-03.xls & SAC_Updates_9-23-03.xls \\
\hline (a) Subdirectory under $\backslash$ data $\mid r$ rev.1 inventorylOther Inventory Datasets. & \\
\hline
\end{tabular}

The detailed assembled inventory is a compilation of annual discharges, disposals, and unplanned losses to the environment. Each entry is decay correct to the end of the year for which it is entered, i.e., December 31 of the data entry year. This assembled inventory captures data from the opening of the Hanford Site in 1944 until closure of much of the site in 2035, and final inventory changes in 2070 following closure of the commercial low-level radioactive waste site operated by US Ecology.

The inventory is simulated using a stochastic model to capture its uncertainty. However, the representation of uncertainty in the inventory is described in the Section 6. To discuss and better understand aspects of the inventory, it is accumulated and decay corrected at three moments in time to provide meaningful displays. The three moments in time selected are 2005, 2035, and 2070; essentially today, virtual site closure, and final site closure. The best estimate value of the accumulated inventory in each waste site at these moments in time is presented in Appendices E, F, and G. Each waste site - analyte inventory has been color coded to indicate which cells derive from the Hanford SIM, the HTWOS model, records (e.g., SWITS), estimates (fill-in rules), and surrogate rules. The resulting percentage breakdown of the origin of inventories by analyte for 2005, 2035, and 2070 are shown in Tables 5.9, 5.10, and 5.11. Note that some sites have multiple sources of inventory data.

Changes in the inventory source percentages between 2005 and later years are highlighted by the introduction of tank waste processing (i.e., the HTWOS model data) which accounts for nothing in 2005 and is complete by 2035. Changes after 2035 seen in Table 5.11 are a function of continued disposal at the commercial low-level radioactive waste site until 2056, (e.g., note the change in tritium inventory). The Hanford SIM entries are static after 2005. The record entries are static after 2005 with the exception of solid waste disposals and disposals to the commercial low-level waste disposal site. Shifts in percentages are dominated by the introduction of the HTWOS model data. Clearly the fill-in rule estimates and 
the surrogate rule estimates have a nil, or very near zero, influence on the total inventory analyzed. Surrogate rule estimates generally are much less than $1 \%$ with only europium- 152 showing more than $1 \%$; with a half-life of 13.54 years, it will be greatly diminished because of decay not long after Hanford Site closure. The fill-in rule estimates account for nearly $1 \%$ of the iodine- 129 and europium-152, and less than $1 \%$ for all others, most being much less than $1 \%$. The europium- 152 will vanish essentially because of decay in the near term, and the iodine-129 is dominated by Hanford SIM, HTWOS model, and record data and their uncertainty. Data for chlorine-36 are unique because chlorine-36 is in the graphite cores of the nine production reactors and not in the spent fuel or processing waste in substantial quantities. Thus, chlorine-36 appears as a record quantity and not a tank waste inventory analyte. The percentages shown include off-site shipments and glass inventories. This causes uranium inventories to be dominated by record quantities that include spent fuel as well as high-level waste glass canisters, both destined for off-site shipment.

Table 5.9. Percent of the Total Inventory in 2005 (best estimate inputs) by Analyte

\begin{tabular}{||l|c|c|c|c|c||}
\hline \multicolumn{1}{|c|}{ Analyte } & Hanford SIM & HTWOS & Record & Estimated (fill-in) & Surrogate \\
\hline \hline Tritium & 18.67 & 0.00 & 81.18 & 0.00 & 0.15 \\
\hline Carbon-14 & 0.36 & 0.00 & 99.51 & 0.06 & 0.08 \\
\hline Chlorine-36 & 0.00 & 0.00 & 100 & 0.00 & 0.00 \\
\hline Selenium-79 & 2.32 & 0.00 & 96.98 & 0.69 & 0.01 \\
\hline Strontium-90 & 0.14 & 0.00 & 99.55 & 0.28 & 0.03 \\
\hline Technetium-99 & 14.97 & 0.00 & 84.43 & 0.52 & 0.09 \\
\hline Iodine-129 & 21.20 & 0.00 & 76.12 & 2.63 & 0.04 \\
\hline Cesium-137 & 0.32 & 0.00 & 99.38 & 0.28 & 0.02 \\
\hline Europium-152 & 0.18 & 0.00 & 90.26 & 1.77 & 7.79 \\
\hline Uranium-233 & 61.13 & 0.00 & 38.28 & 0.00 & 0.59 \\
\hline Uranium-235 & 3.09 & 0.00 & 95.98 & 0.67 & 0.26 \\
\hline Neptunium-237 & 36.79 & 0.00 & 63.21 & 0.00 & 0.01 \\
\hline Uranium-234/238 & 2.74 & 0.00 & 97.02 & 0.00 & 0.24 \\
\hline
\end{tabular}

Table 5.10. Percent of the Total Inventory in 2035 (best estimate inputs) by Analyte

\begin{tabular}{||l|c|c|c|c|c||}
\hline \multicolumn{1}{|c|}{ Analyte } & Hanford SIM & HTWOS & Record & Estimated (fill-in) & Surrogate \\
\hline Tritium & 16.40 & 1.09 & 82.39 & 0.00 & 0.13 \\
\hline Carbon-14 & 0.35 & 1.43 & 98.09 & 0.05 & 0.07 \\
\hline Chlorine-36 & 0.00 & 0.00 & 100 & 0.00 & 0.00 \\
\hline Selenium-79 & 1.16 & 49.91 & 48.58 & 0.35 & 0.00 \\
\hline Strontium-90 & 0.06 & 56.88 & 42.93 & 0.12 & 0.01 \\
\hline Technetium-99 & 2.19 & 85.33 & 12.39 & 0.08 & 0.01 \\
\hline Iodine-129 & 7.23 & 65.57 & 26.26 & 0.92 & 0.01 \\
\hline Cesium-137 & 0.19 & 40.00 & 59.63 & 0.17 & 0.01 \\
\hline Europium-152 & 0.11 & 40.79 & 53.43 & 1.06 & 4.61 \\
\hline Uranium-233 & 14.76 & 75.86 & 9.24 & 0.00 & 0.14 \\
\hline Uranium-235 & 2.83 & 8.50 & 87.82 & 0.61 & 0.24 \\
\hline Neptunium-237 & 19.66 & 46.55 & 33.78 & 0.00 & 0.00 \\
\hline Uranium-234/238 & 2.53 & 7.70 & 89.55 & 0.00 & 0.22 \\
\hline
\end{tabular}


Table 5.11. Percent of the Total Inventory in 2070 (best estimate inputs) by Analyte

\begin{tabular}{||l|c|c|c|c|c||}
\hline \multicolumn{1}{|c|}{ Analyte } & Hanford SIM & HTWOS & Record & Estimated (fill-in) & Surrogate \\
\hline Tritium & 12.55 & 0.83 & 86.52 & 0.00 & 0.10 \\
\hline Carbon-14 & 0.35 & 1.42 & 98.10 & 0.05 & 0.07 \\
\hline Chlorine-36 & 0.00 & 0.00 & 100 & 0.00 & 0.00 \\
\hline Selenium-79 & 1.16 & 49.91 & 48.58 & 0.35 & 0.00 \\
\hline Strontium-90 & 0.06 & 56.87 & 42.93 & 0.12 & 0.01 \\
\hline Technetium-99 & 2.19 & 85.33 & 12.39 & 0.08 & 0.01 \\
\hline Iodine-129 & 7.21 & 65.44 & 26.41 & 0.92 & 0.01 \\
\hline Cesium-137 & 0.19 & 40.00 & 59.63 & 0.17 & 0.01 \\
\hline Europium-152 & 0.11 & 40.79 & 53.43 & 1.06 & 4.61 \\
\hline Uranium-233 & 14.76 & 75.86 & 9.24 & 0.00 & 0.14 \\
\hline Uranium-235 & 2.83 & 8.50 & 87.83 & 0.61 & 0.24 \\
\hline Neptunium-237 & 19.66 & 46.55 & 33.78 & 0.00 & 0.00 \\
\hline Uranium-234/238 & 2.53 & 7.70 & 89.55 & 0.00 & 0.22 \\
\hline \hline
\end{tabular}




\subsection{Stochastic Inventory Concepts}

The Inventory Module uses information from the inventory database and other assessment setup data to generate stochastic realizations of inventory, to aggregate inventories for sites identified for aggregation and account for radioactive decay to the end of each year. All disposal actions are described as contaminant concentrations within a disposal volume. The volumes and concentrations are both treated as stochastic quantities. It is possible to obtain a deterministic inventory by running a single realization with a fixed set of inputs.

\subsection{Uncertainty in Soil Inventory Model (SIM) Data}

The Hanford SIM (Corbin et al. 2005) data set was provided in a stochastic format. This data set provided inventory estimates for liquid releases for 377 waste sites. The majority of these sites are located on the Central Plateau of Hanford; however, four are located in the 300 Area. An example SIM data set for a liquid release from 200-E-25 in 1971 is provided in Table 6.1. The SIM data are represented by a 21-point cumulative probability function for the volume of the waste stream and also for each analyte in the waste stream. Analytes not present in the SIM analyses are not estimated using any fill-in rules because the SIM analysts checked for the presence of these analytes when the data were generated. Thus, for the SIM data, a missing inventory within a waste stream implies a zero inventory rather than lack of information.

Table 6.1. SIM Volume and Concentration Data for 200-E-25 for 1971 Liquid Releases

\begin{tabular}{||c|c|c|c|c||}
\hline \hline Probability & Volume $\left(\mathrm{m}^{3}\right)$ & Uranium-234 $\left(\mathrm{Ci} / \mathrm{m}^{3}\right)$ & Uranium-235 $\left(\mathrm{Ci} / \mathrm{m}^{3}\right)$ & Uranium-238 $\left(\mathrm{Ci} / \mathrm{m}^{3}\right)$ \\
\hline \hline 0 & 1 & $4.15 \mathrm{E}-14$ & $5.90 \mathrm{E}-16$ & $2.32 \mathrm{E}-14$ \\
\hline 0.05 & 1.2 & $1.80 \mathrm{E}-12$ & $4.38 \mathrm{E}-14$ & $1.18 \mathrm{E}-12$ \\
\hline 0.1 & 1.32 & $5.65 \mathrm{E}-12$ & $1.61 \mathrm{E}-13$ & $3.87 \mathrm{E}-12$ \\
\hline 0.15 & 1.41 & $1.12 \mathrm{E}-11$ & $3.46 \mathrm{E}-13$ & $7.72 \mathrm{E}-12$ \\
\hline 0.2 & 1.49 & $1.82 \mathrm{E}-11$ & $6.00 \mathrm{E}-13$ & $1.27 \mathrm{E}-11$ \\
\hline 0.25 & 1.56 & $2.66 \mathrm{E}-11$ & $9.22 \mathrm{E}-13$ & $1.89 \mathrm{E}-11$ \\
\hline 0.3 & 1.62 & $3.66 \mathrm{E}-11$ & $1.32 \mathrm{E}-12$ & $2.61 \mathrm{E}-11$ \\
\hline 0.35 & 1.68 & $4.83 \mathrm{E}-11$ & $1.79 \mathrm{E}-12$ & $3.47 \mathrm{E}-11$ \\
\hline 0.4 & 1.73 & $6.18 \mathrm{E}-11$ & $2.34 \mathrm{E}-12$ & $4.45 \mathrm{E}-11$ \\
\hline 0.45 & 1.78 & $7.69 \mathrm{E}-11$ & $2.99 \mathrm{E}-12$ & $5.58 \mathrm{E}-11$ \\
\hline 0.5 & 1.83 & $9.44 \mathrm{E}-11$ & $3.75 \mathrm{E}-12$ & $6.90 \mathrm{E}-11$ \\
\hline 0.55 & 1.87 & $1.14 \mathrm{E}-10$ & $4.63 \mathrm{E}-12$ & $8.39 \mathrm{E}-11$ \\
\hline 0.6 & 1.92 & $1.37 \mathrm{E}-10$ & $5.66 \mathrm{E}-12$ & $1.01 \mathrm{E}-10$ \\
\hline 0.65 & 1.97 & $1.64 \mathrm{E}-10$ & $6.86 \mathrm{E}-12$ & $1.22 \mathrm{E}-10$ \\
\hline 0.7 & 2.03 & $1.96 \mathrm{E}-10$ & $8.31 \mathrm{E}-12$ & $1.45 \mathrm{E}-10$ \\
\hline 0.75 & 2.09 & $2.33 \mathrm{E}-10$ & $1.01 \mathrm{E}-11$ & $1.75 \mathrm{E}-10$ \\
\hline 0.8 & 2.16 & $2.80 \mathrm{E}-10$ & $1.22 \mathrm{E}-11$ & $2.11 \mathrm{E}-10$ \\
\hline 0.85 & 2.24 & $3.41 \mathrm{E}-10$ & $1.51 \mathrm{E}-11$ & $2.58 \mathrm{E}-10$ \\
\hline 0.9 & 2.33 & $4.25 \mathrm{E}-10$ & $1.90 \mathrm{E}-11$ & $3.24 \mathrm{E}-10$ \\
\hline 0.95 & 2.45 & $5.64 \mathrm{E}-10$ & $2.56 \mathrm{E}-11$ & $4.36 \mathrm{E}-10$ \\
\hline 1 & 2.65 & $9.82 \mathrm{E}-10$ & $4.52 \mathrm{E}-11$ & $7.80 \mathrm{E}-10$ \\
\hline \hline
\end{tabular}


The mean and standard deviation of the SIM data were provided in addition to the information shown in Table 6.1. The best estimate inventory developed for some applications used the mean value of the SIM data rather than the stochastic representation illustrated here.

The A-10 crib (waste site 216-A-10) is a site that is known to have released large quantities of tritium. The description of inventory from the SIM data set for this site in the year 1965 is provided in Table 6.2.

Table 6.2. SIM Volume and Concentration Data for 216-A-10 for 1965 Liquid Releases

\begin{tabular}{|c|c|c|c|c|c|c|c|}
\hline $\begin{array}{l}\text { Cumulative } \\
\text { Probability }\end{array}$ & $\begin{array}{l}\text { Volume } \\
\qquad\left(\mathrm{m}^{3}\right)\end{array}$ & $\begin{array}{l}\text { Tritium } \\
\left(\mathrm{Ci} / \mathrm{m}^{3}\right)\end{array}$ & $\begin{array}{l}\text { Technetium-99 } \\
\left(\mathrm{Ci} / \mathrm{m}^{3}\right)\end{array}$ & $\begin{array}{l}\text { Iodine-129 } \\
\left(\mathrm{Ci} / \mathrm{m}^{3}\right)\end{array}$ & $\begin{array}{l}\text { Uranium-234 } \\
\qquad\left(\mathrm{Ci} / \mathrm{m}^{3}\right)\end{array}$ & $\begin{array}{l}\text { Uranium-235 } \\
\qquad\left(\mathrm{Ci} / \mathrm{m}^{3}\right)\end{array}$ & $\begin{array}{l}\text { Uranium-238 } \\
\qquad\left(\mathrm{Ci} / \mathrm{m}^{3}\right)\end{array}$ \\
\hline 0 & $3.01 \mathrm{E}+05$ & $7.15 \mathrm{E}-05$ & $5.17 \mathrm{E}-11$ & $1.88 \mathrm{E}-10$ & $2.16 \mathrm{E}-14$ & $4.12 \mathrm{E}-16$ & $3.52 \mathrm{E}-15$ \\
\hline 0.05 & $3.22 \mathrm{E}+05$ & $2.12 \mathrm{E}-03$ & 2.16E-09 & 7.88E-09 & $1.59 \mathrm{E}-11$ & 4.32E-13 & $6.28 \mathrm{E}-12$ \\
\hline 0.1 & $3.34 \mathrm{E}+05$ & $5.86 \mathrm{E}-03$ & $6.67 \mathrm{E}-09$ & $2.40 \mathrm{E}-08$ & $1.18 \mathrm{E}-10$ & $3.58 \mathrm{E}-12$ & $5.84 \mathrm{E}-11$ \\
\hline 0.15 & $3.44 \mathrm{E}+05$ & $1.08 \mathrm{E}-02$ & $1.30 \mathrm{E}-08$ & 4.62E-08 & $3.81 \mathrm{E}-10$ & $1.22 \mathrm{E}-11$ & $2.15 \mathrm{E}-10$ \\
\hline 0.2 & $3.52 \mathrm{E}+05$ & $1.66 \mathrm{E}-02$ & 2.09E-08 & $7.41 \mathrm{E}-08$ & $8.75 \mathrm{E}-10$ & $2.95 \mathrm{E}-11$ & $5.43 \mathrm{E}-10$ \\
\hline 0.25 & $3.60 \mathrm{E}+05$ & $2.33 \mathrm{E}-02$ & $3.04 \mathrm{E}-08$ & $1.08 \mathrm{E}-07$ & $1.68 \mathrm{E}-09$ & $5.83 \mathrm{E}-11$ & $1.12 \mathrm{E}-09$ \\
\hline 0.3 & $3.66 \mathrm{E}+05$ & $3.10 \mathrm{E}-02$ & $4.15 \mathrm{E}-08$ & $1.46 \mathrm{E}-07$ & $2.84 \mathrm{E}-09$ & $1.02 \mathrm{E}-10$ & $2.02 \mathrm{E}-09$ \\
\hline 0.35 & $3.72 \mathrm{E}+05$ & $3.97 \mathrm{E}-02$ & $5.44 \mathrm{E}-08$ & $1.91 \mathrm{E}-07$ & 4.48E-09 & $1.65 \mathrm{E}-10$ & $3.35 \mathrm{E}-09$ \\
\hline 0.4 & $3.78 \mathrm{E}+05$ & 4.93E-02 & $6.87 \mathrm{E}-08$ & 2.42E-07 & $6.66 \mathrm{E}-09$ & $2.49 \mathrm{E}-10$ & $5.17 \mathrm{E}-09$ \\
\hline 0.45 & $3.83 \mathrm{E}+05$ & $6.02 \mathrm{E}-02$ & $8.54 \mathrm{E}-08$ & $2.99 \mathrm{E}-07$ & $9.48 \mathrm{E}-09$ & $3.62 \mathrm{E}-10$ & 7.67E-09 \\
\hline 0.5 & $3.88 \mathrm{E}+05$ & $7.21 \mathrm{E}-02$ & $1.04 \mathrm{E}-07$ & $3.65 \mathrm{E}-07$ & $1.31 \mathrm{E}-08$ & $5.09 \mathrm{E}-10$ & $1.09 \mathrm{E}-08$ \\
\hline 0.55 & $3.93 \mathrm{E}+05$ & $8.58 \mathrm{E}-02$ & $1.25 \mathrm{E}-07$ & 4.37E-07 & $1.76 \mathrm{E}-08$ & $6.94 \mathrm{E}-10$ & $1.52 \mathrm{E}-08$ \\
\hline 0.6 & $3.98 \mathrm{E}+05$ & $1.01 \mathrm{E}-01$ & $1.49 \mathrm{E}-07$ & $5.23 \mathrm{E}-07$ & 2.34E-08 & $9.31 \mathrm{E}-10$ & $2.06 \mathrm{E}-08$ \\
\hline 0.65 & $4.04 \mathrm{E}+05$ & $1.19 \mathrm{E}-01$ & $1.77 \mathrm{E}-07$ & $6.19 \mathrm{E}-07$ & $3.06 \mathrm{E}-08$ & $1.23 \mathrm{E}-09$ & $2.76 \mathrm{E}-08$ \\
\hline 0.7 & $4.10 \mathrm{E}+05$ & 1.39E-01 & $2.10 \mathrm{E}-07$ & $7.30 \mathrm{E}-07$ & $3.97 \mathrm{E}-08$ & $1.61 \mathrm{E}-09$ & $3.67 \mathrm{E}-08$ \\
\hline 0.75 & $4.16 \mathrm{E}+05$ & $1.62 \mathrm{E}-01$ & $2.48 \mathrm{E}-07$ & $8.63 \mathrm{E}-07$ & $5.14 \mathrm{E}-08$ & $2.11 \mathrm{E}-09$ & $4.84 \mathrm{E}-08$ \\
\hline 0.8 & $4.24 \mathrm{E}+05$ & $1.90 \mathrm{E}-01$ & 2.94E-07 & $1.03 \mathrm{E}-06$ & $6.67 \mathrm{E}-08$ & 2.77E-09 & $6.41 \mathrm{E}-08$ \\
\hline 0.85 & $4.32 \mathrm{E}+05$ & $2.26 \mathrm{E}-01$ & $3.52 \mathrm{E}-07$ & $1.22 \mathrm{E}-06$ & $8.78 \mathrm{E}-08$ & $3.68 \mathrm{E}-09$ & $8.58 \mathrm{E}-08$ \\
\hline 0.9 & $4.42 \mathrm{E}+05$ & $2.74 \mathrm{E}-01$ & $4.30 \mathrm{E}-07$ & $1.50 \mathrm{E}-06$ & $1.19 \mathrm{E}-07$ & $5.04 \mathrm{E}-09$ & $1.19 \mathrm{E}-07$ \\
\hline 0.95 & $4.54 \mathrm{E}+05$ & $3.49 \mathrm{E}-01$ & $5.55 \mathrm{E}-07$ & $1.93 \mathrm{E}-06$ & $1.75 \mathrm{E}-07$ & 7.45E-09 & $1.77 \mathrm{E}-07$ \\
\hline 1 & $4.75 \mathrm{E}+05$ & 5.39E-01 & $8.65 \mathrm{E}-07$ & $3.06 \mathrm{E}-06$ & $3.60 \mathrm{E}-07$ & $1.54 \mathrm{E}-08$ & $3.78 \mathrm{E}-07$ \\
\hline
\end{tabular}

An example inventory calculation utilizing 5,000 realizations was conducted for this site. The tritium inventory ranges from 27.17 to $247,335 \mathrm{Ci}$ and has a median of $28,051 \mathrm{Ci}$ and a mean of 43,212 $\mathrm{Ci}$. The generated inventory distribution is shown in Figure 6.1. Although the SIM data set has a reasonable amount of variability in the inventory for many sites, the inventory for this site, along with a few other sites that release large quantities of tritium, exhibits an unreasonably large variability. Further development work and data collection is required for the SIM model to produce estimates with a narrower range of variability. As a mitigating factor, when the releases from the A-10 crib are summed over the several years the crib operated, the resulting total is less variable than the data for each individual year. 


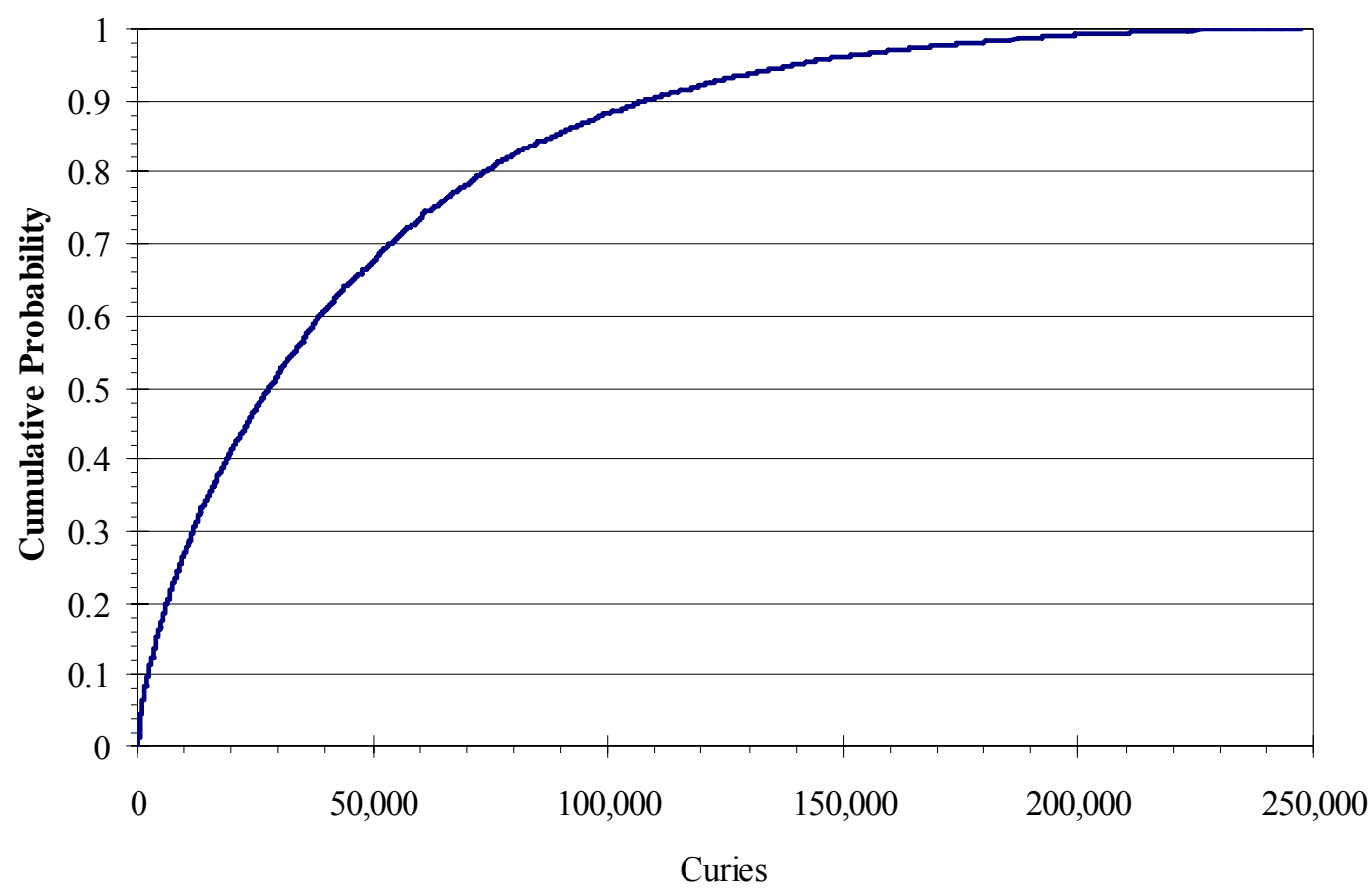

Figure 6.1. Cumulative Probability Function for the Tritium Inventory (Ci) Discharged to the 216-A-10 Crib in 1965 Based on the SIM Data Set

\subsection{Uncertainty in All Other Inventory Data}

For all sites not quantified by the SIM data, the Inventory Module simulates waste volumes and concentrations using a series of stochastic rules:

- All volume discharges were assigned a $20 \%$ uncertainty about the record or estimated volume of waste. This approach to uncertainty was adopted after consulting with current and retired Hanford staff familiar with inventory records. This uncertainty is implemented as a multiplier on the point estimate of volume, and the multiplier is defined as having a triangular distribution extending from 0.8 to 1.2 that is centered on 1 .

- Consultations with current and retired Hanford staff familiar with inventory records indicated that individual site-specific inventories could be as much as 20-fold uncertain prior to 1970. Therefore, the analyte concentrations in waste streams released prior to 1970 were modeled with a lognormal (natural $\log$ ) distribution, truncated at the 0.01 and 0.99 probability levels. The mean of the untruncated distribution was set to the point estimate or record value. The spread of the distribution was chosen by setting the standard deviation equal to twice the mean. This choice gave a wide variability representative of the stated 20 -fold uncertainty of data during this operational era.

- Consultations with current and retired Hanford staff familiar with inventory records also indicated that individual site-specific inventory estimates were much more accurate after more detailed record keeping was initiated in 1970 and the variability was more in the range of one-half the record value to twice the recorded value. The analyte concentrations in waste streams released from 1970 on were also modeled with a lognormal (natural $\log$ ) distribution, truncated at the 0.01 and 0.99 
probability levels where the mean of the untruncated distribution was set to the point estimate or record value. However, the spread of the distribution was chosen by setting the standard deviation equal to 0.25 times the mean. This choice gave a much narrower variability representative of the stated one-half to two fold uncertainty of data during this operational era.

- An exception to the inventory rule is that all production reactor core inventories are assumed to be relatively well known irrespective of the date they enter the inventory record. Therefore, the post-1970 rule (smaller variability) was assigned to all Hanford Site production reactor cores.

In a few cases, a zero inventory was assigned to an analyte in a waste stream to preclude the application of a fill-in rule to that waste form. For these cases, the stochastic inventory was defined as a constant value of zero and did not implement any variability.

An example illustration of the variability rule applications is provided for the chlorine-36 inventory in D Reactor for a stochastic calculation utilizing 5,000 realizations. The record data set has a point estimate of $33.998 \mathrm{Ci}$ of chlorine-36 and a disposal volume of $2,000 \mathrm{~m}^{3}$ for this reactor. Using the above rules, the stochastic volume distribution would be triangular on the range 1,600 to $2,400 \mathrm{~m}^{3}$. The sampled volume values range from $1,605.03$ to $2,394.44 \mathrm{~m}^{3}$ with a mean value of $2,000.00$ and a median value of $2,000.02$. The stochastic concentration distribution using the variability assumptions for pre-1970 data would use a mean value (in log space) of -4.87893 and a standard deviation (in log space) of 1.26864. The stochastic concentration distribution using the variability assumptions for post-1969 data would use the mean (in log space) of -4.104913 and a standard deviation (in log space) of 0.246221 . For the pre-1970 variability assumptions, the generated inventory values (in curies) run from 0.726 to 319.2 with a mean of 29.66. For the post-1969 variability assumptions, the generated inventory values (in curies) run from 15.88 to 64.50 with a mean of 33.87 . The cumulative distribution function for these two sets of sampled inventories are shown graphically in Figure 6.2.

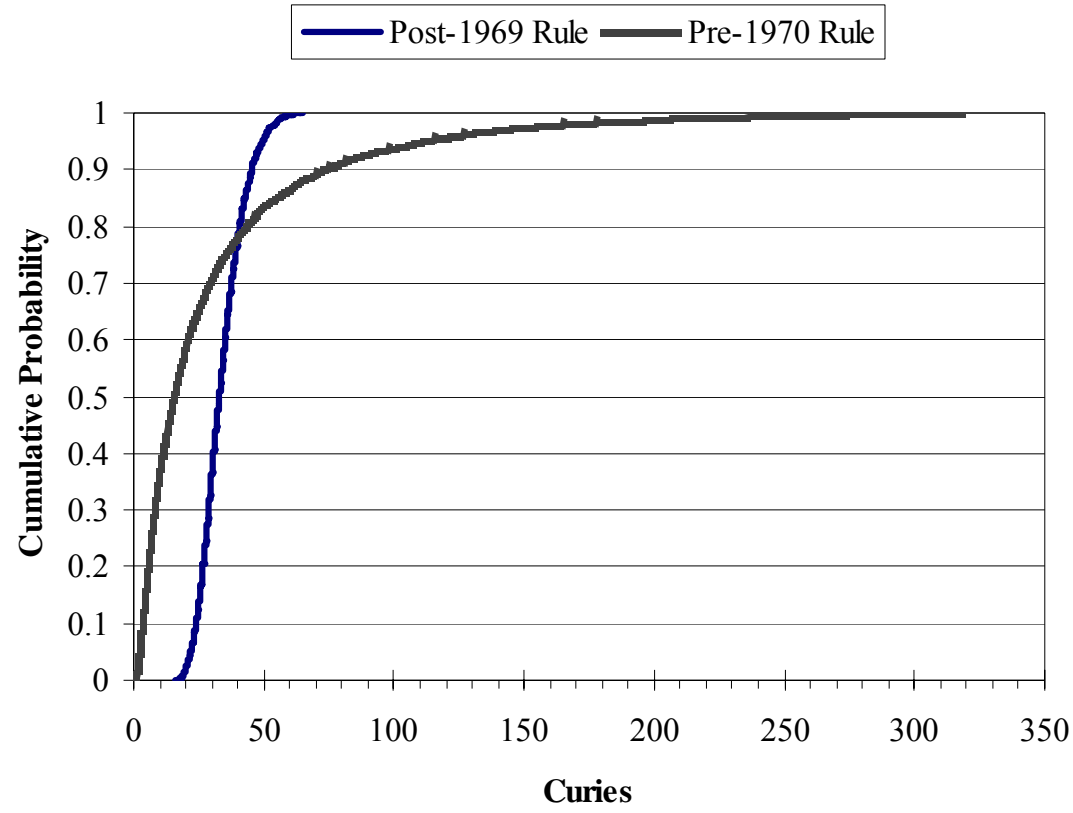

Figure 6.2. Example Cumulative Probability Functions for Chlorine-36 Inventory in D Reactor Using Pre-1970 and Post-1969 Uncertainty Rules 
Another example illustration of the variability rule applications is provided for an iodine-129 inventory in the assumed IDF (218-E-RCRA) for a stochastic calculation utilizing 5,000 realizations. The record data set has a point estimate of $0.33493 \mathrm{Ci}$ of iodine-129 in a cement waste form with a disposal volume of $483.146 \mathrm{~m}^{3}$ that is scheduled for disposal in the year 2011. The generated values range from 0.1583 to $0.6566 \mathrm{Ci}$ and have a mean value of $0.3337 \mathrm{Ci}$. The standard deviation of the generated values was 0.0823 . The cumulative distribution function for this disposal action is shown graphically in Figure 6.3 .

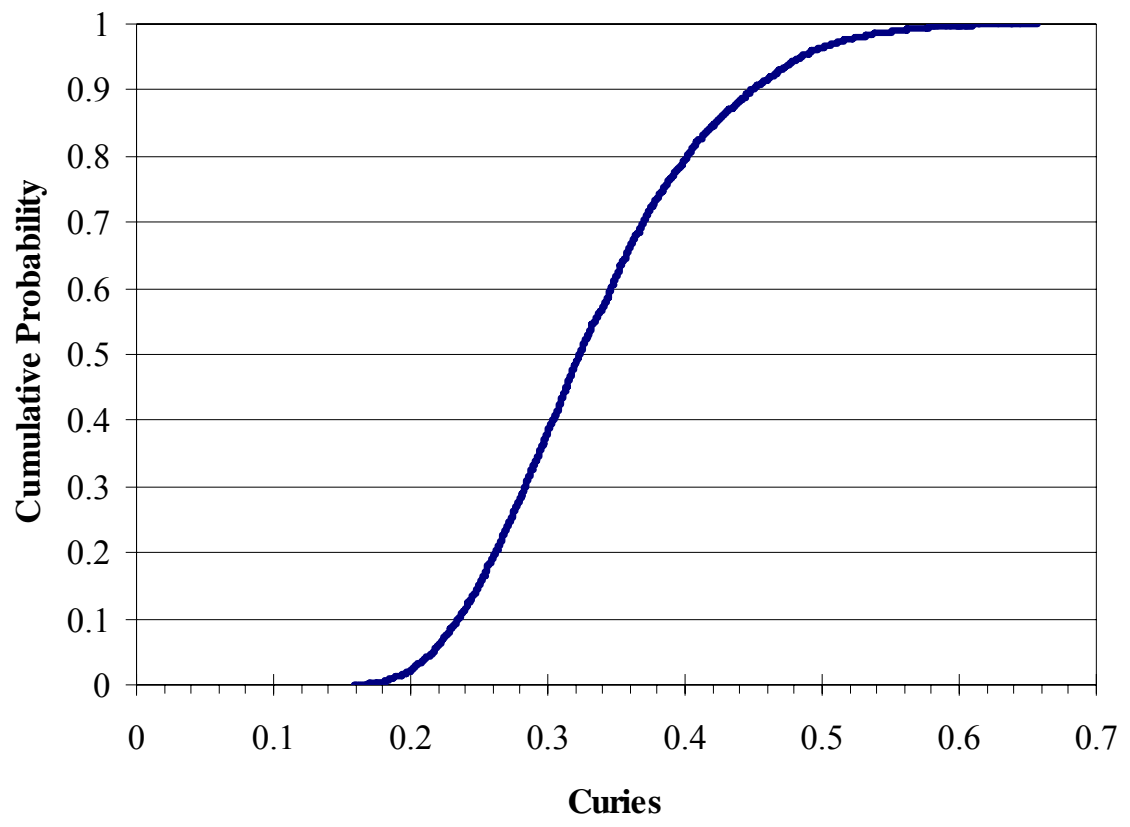

Figure 6.3. Example Cumulative Probability Functions for Iodine-129 Inventory in the Assumed IDF for a Single Cement Disposal Scheduled for 2011

A final illustration of the variability rule application is provided for disposal of some unsegregated trench waste containing uranium-238 at the 218-W-4A site in 1965. Results are provided for a stochastic calculation utilizing 5,000 realizations. The record data set has a point estimate of $31.98 \mathrm{Ci}$ of uranium-238 in a disposal volume of $2,061.48 \mathrm{~m}^{3}$. The generated inventory values range from 0.6828 to $300.22 \mathrm{Ci}$ and have a mean value of $27.89 \mathrm{Ci}$. The truncation of the lower and upper $1 \%$ of the tails of the distribution for concentration preserves the median of the generated data but it does introduce a small downward bias on the mean value. The bias is much smaller when using the post-1969 variability rule than when using the pre-1970 variability rule.

\subsection{Uncertainty in Total Onsite Inventory}

A stochastic inventory run using 100 realizations was made for all onsite disposal actions. The use of 100 realizations is a modeling convenience for limiting run times. Summary statistics in the onsite inventory (curies) for four analytes are provided in Table 6.3: tritium, technetium-99, iodine-129, and uranium-234/238. Graphical representations of the variability in the inventory for these four analytes are provided in Figures 6.4 through 6.7. The best estimate for the onsite inventories is also provided to 
illustrate that the best estimate inventory lies near the middle of the stochastic inventory values. Although there is some variability in the stochastic values for total on-site inventory, the variability in the total is relatively small.

Table 6.3. Summary Statistics for Onsite Inventory for Selected Analytes ${ }^{(a)}$

\begin{tabular}{||l|c|c|c|c||}
\hline \multicolumn{1}{|c|}{ Analyte } & Tritium $(\mathrm{Ci})$ & $\begin{array}{c}\text { Technetium-99 } \\
(\mathrm{Ci})\end{array}$ & $\begin{array}{c}\text { Iodine-129 } \\
(\mathrm{Ci})\end{array}$ & $\begin{array}{c}\text { Uranium-234/ } \\
\text { Uranium-238 (Ci) }\end{array}$ \\
\hline \hline Minimum & 24,640 & 20,560 & 49.3 & 2,730 \\
\hline Median & 26,660 & 23,700 & 55.5 & 3,444 \\
\hline Maximum & 28,700 & 30,100 & 62.0 & 4,349 \\
\hline Mean & 26,680 & 23,860 & 55.5 & 3,433 \\
\hline Standard Deviation & 950 & 1,460 & 2.2 & 265 \\
\hline Best Estimate & 26,860 & 23,950 & 55.9 & 3,505 \\
\hline (a) Decay corrected to 2070.
\end{tabular}

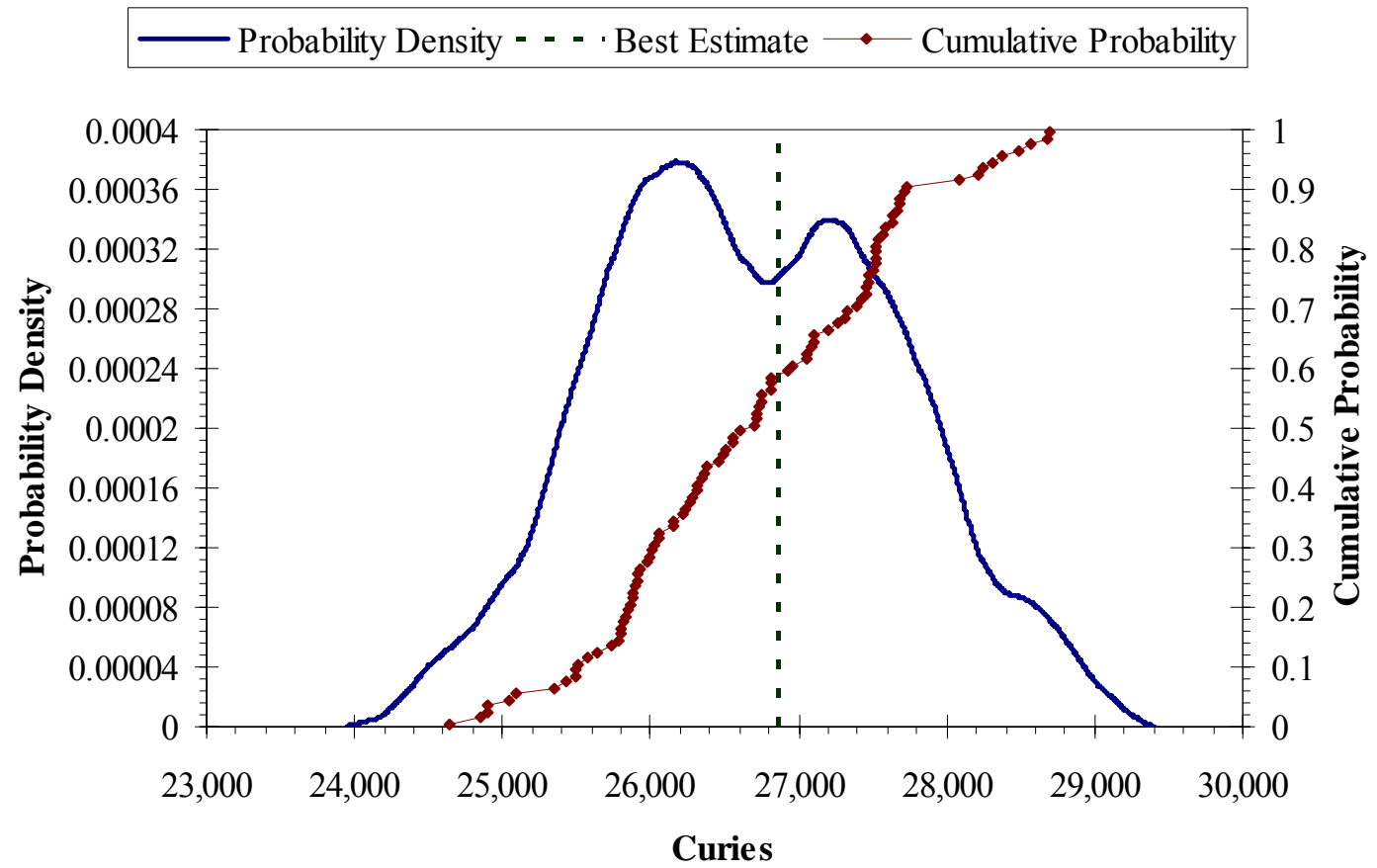

Figure 6.4. Example Stochastic Representation of Onsite Tritium Inventory (decay corrected to 2070) 


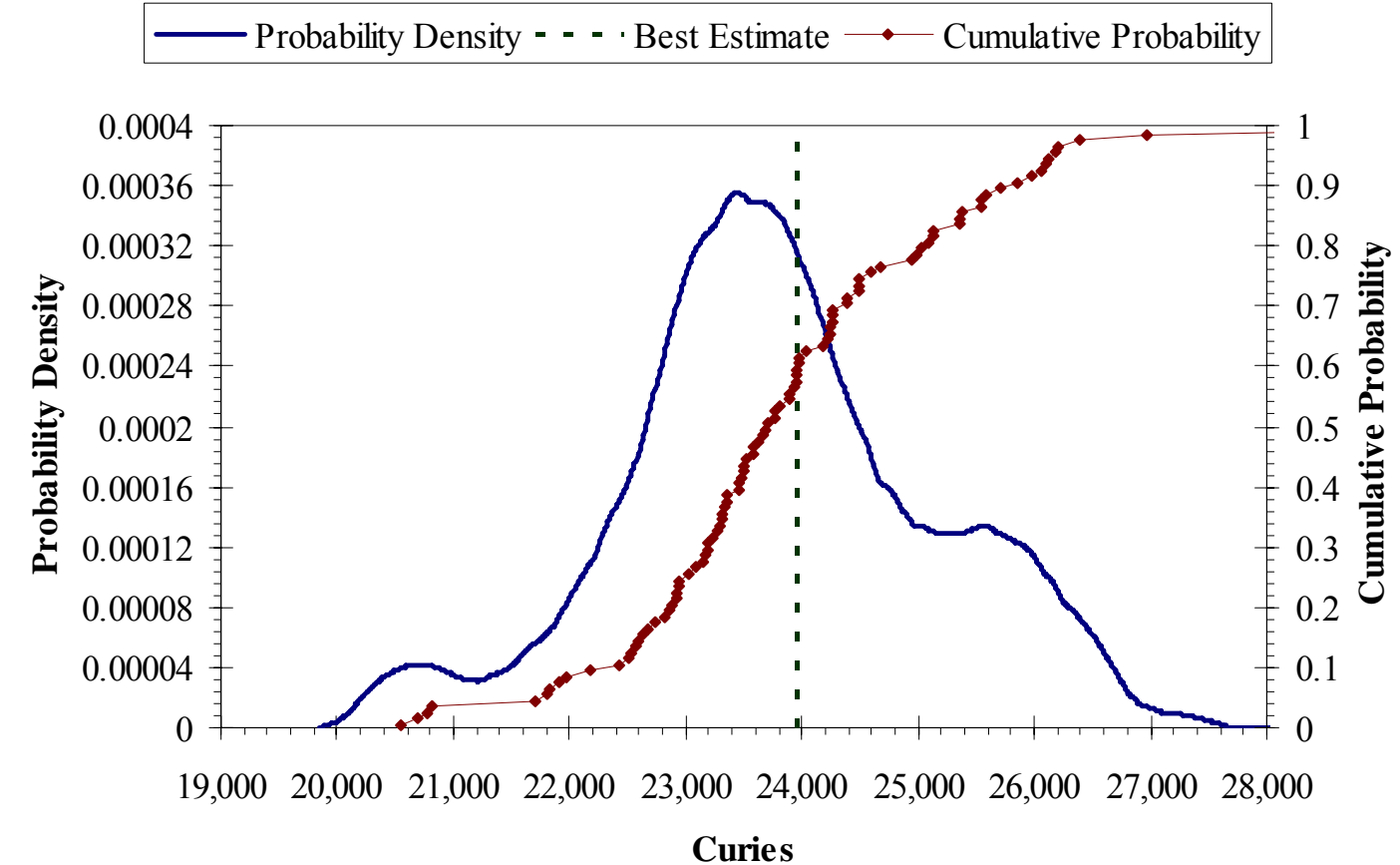

Figure 6.5. Example Stochastic Representation of Onsite Technetium-99 Inventory (decay corrected to 2070)

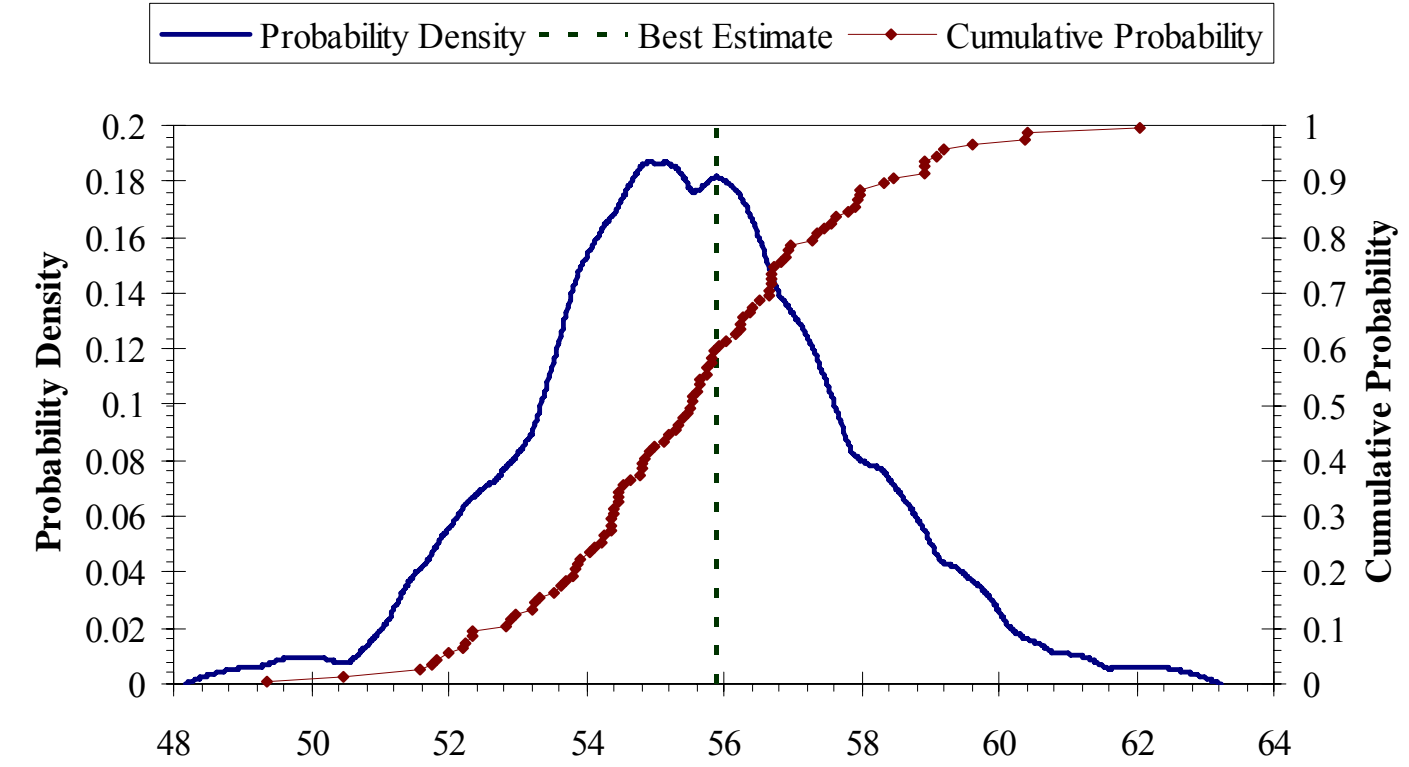

Curies

Figure 6.6. Example Stochastic Representation of Onsite Iodine-129 Inventory (decay corrected to 2070) 


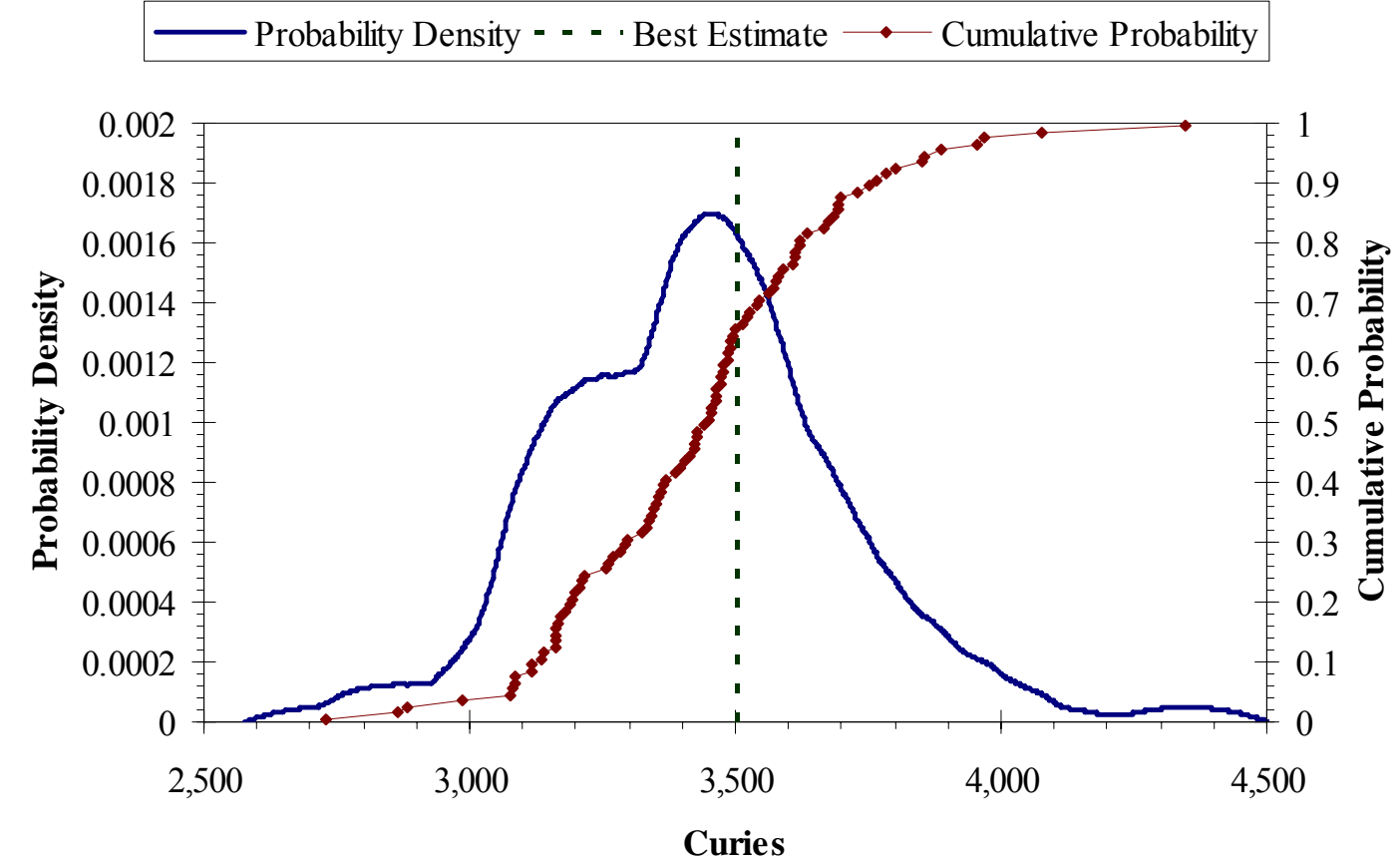

Figure 6.7. Example Stochastic Representation of Onsite Uranium-234/238 Inventory (decay corrected to 2070) 


\subsection{Quality Assurance}

This section presents efforts performed to assure the quality, traceability, and reproducibility of the assembled inventory. When efforts to assemble a comprehensive inventory were initiated in 1999, development of a proof-of-principle data set was the goal. Today, a data set and modeling capability suitable for regulatory application is desired. As described in Section 5, the building blocks for this inventory are the products of many diverse efforts to assemble or estimate inventories for individual waste types including liquid discharges and unplanned releases, past and future solid waste, reactor cores, spent fuel, canyons, and tank waste. Some of these efforts date to the proof-of-principle period (1999-2002) of the effort. Independent review, additional data collection, and implementation of a configuration control system have all helped in the effort to migrate from a proof-of-principle data set to a data set that is adequate to support regulatory analyses.

Each of the data files named in Section 5 are now archived and maintained on the SAC share, i.e., the SAC Windows File server at $\backslash$ sac.pnl.gov $\backslash$ share $\backslash$ datalrev.1 1 inventory $\backslash$. There are two exceptions, files providing the releases to the water table from the draft IDF performance assessment (Puigh and Wood 2005) are stored at $\backslash \backslash$ sac.pnl.gov $\backslash$ share $\backslash$ data $\backslash$ rev.1\3rdparty.releases $\backslash$. The files containing releases from the assumed IDF are not under configuration management; however, they are traceable to their original source and provide an assurance of reproducibility for the assembled inventory. In addition, the inventory database resides on a more powerful server. However, a static copy of the inventory database that produces the input file for INPROC has been archived on the SAC share at IIsac.pnl.gov\share $\backslash$ data $\backslash$ rev.1 1 inventory $\backslash$ Static-Inventory-Database_2005-11-03 to provide data traceability to the current inventory data file.

Three files are maintained under configuration management for the inventory on the SAC share. They are the following:

- 'Attributes_2006-01-04_DCR-0029.xls' - this file is described briefly in Appendix B and is attached as an electronic appendix.

- 'inproc-input_2005-11-09_DCR-0024.xls' - this is the input file for the INPROC code which generates the inventory file for an assessment. It creates the waste site/year/analyte inventory file for an assessment by applying the fill-in and surrogate rules described in Section 4 to the inventory data described in Section 5 using the uncertainty rules described in Section 6.

- 'RMDLIB_2005-10-07_DCR-0014.DAT' -- this is a radionuclide chain decay library.

A readiness review was conducted prior to placing each data set under configuration management. All subsequent changes are managed and documented via a data change request. Each revised data set is uniquely identified with a descriptive name, the date the data set was revised, and the corresponding data change request number.

During the readiness review of data supporting the assembled inventory, a $100 \%$ check was performed to ensure that each data entry in the waste site/year/analyte data file traced back to an inventory record or model result archived and maintained on the SAC share, i.e., the SAC Windows File 
server at \\sac.pnl.gov\share\data\rev.1 \inventory\. The data in the Attributes files were also independently cross checked against original information. These reviews are documented in the data change requests.

During the development and assembly of the inventory, and during the peer review of this document, several items deserving of future review and revision have been identified. They fall into four general topics:

- Update to acquire the latest data and information. The current mission of the Hanford Site is environmental restoration and waste management. Inactive and closed facilities under CERCLA are being remediated. Active sites under RCRA will be undergo decontamination and decommissioning and will be transferred to CERCLA control for final remedial action and closeout. Both the CERCLA and RCRA activities are generating data and information on the inventories originally discharged and disposed to the environment. Periodically, the latest data and information produced should be used to update this inventory.

- Update fill-in and surrogate rules. The current fill-in rules are directly related to fill-in rules used in the completion of liquid discharge and solid waste inventory estimates for inactive waste sites at Hanford. This implies a consistency with past efforts made to estimate fission products, activation products, and uranium isotopes and totals when only limited data were available. When created, these rules were simplified to make their application efficient, and that was prior to the development of today's databases and computers. For example, average uranium isotopic ratios were adopted for all time. However, we know the time history of reactor fuel irradiated and processed at Hanford, and it would be possible to adopt a more highly resolved model today. The surrogate rules adopted in this work are a function of a review of waste site specific WIDS data and professional judgment. Efforts to update these surrogate rules would benefit from the participation of DOE contractors and regulators.

- Update tank waste representation. The HTWOS model is undergoing continuous modification as the BBI is updated quarterly, and as models and parameters describing tank waste recovery, separation, and solidification are matched to current DOE plans and Waste Treatment Plant design.

- Update liquid discharge and unplanned release. As field investigation and feasibility studies are conducted and completed for the CERCLA and RCRA sites, we are gaining knowledge of the contamination that remains in the vadose zone beneath waste sites. That information can be used to history match simulation capabilities. Regarding the inventory, the field data can indicate the absence or presence and abundance of selected contaminants, and be used to revise and refine the waste composition used our model of major liquid discharges and unplanned releases, i.e., the Hanford SIM.

The assembled inventory is the result of a multiyear effort by multiple projects and contractors. It is the judgment of the authors that it is adequate for assessments that support decision making at this time. As time and resources permit, periodic update efforts as outlined above would certainly improve the quality and accuracy of the assembled inventory. 


\subsection{References}

Agnew SF, J Boyer, RA Corbin, TB Duran, JR Fitzpatrick, KA Jurgensen, TP Ortiz, and BL Young. 1997. Hanford Tank Chemical and Radionuclide Inventories: HDW Model. LA-UR-96-3860, Rev. 4, Los Alamos National Laboratory, Los Alamos, New Mexico.

Anderson BV. 1958. Regional Monitoring - Data Summary All Results for Year 1957. HW-89066, General Electric Company, Hanford Atomic Products Operation, Richland, Washington.

Anderson JD. 1976. Input and Decayed Values of Radioactive Liquid Wastes Discharged to the Ground in the 200 Areas Through 1975. ARC-CD-745, Atlantic Richfield Hanford Company, Richland, Washington.

Anderson JD. 1996. The History of the 200 Area Burial Ground Facilities. WHC-EP-0912, Volumes 1 and 2, Westinghouse Hanford Company, Richland, Washington.

Barcot, RA. 2003. Solid Waste Integrated Forecast Technical (SWIFT) Report, FY2004-2035 2004.0, Volume 1, HNF-EP-0918, Revision 13, Volume 1, Fluor Hanford, Inc., Richland, Washington.

Bergsman KH. 1994. Hanford Spent Fuel Inventory Baseline. WHC-SD-SNF-TI-001, Rev 0, Westinghouse Hanford Company, Richland, Washington.

BHI. 2003a. January 30, 2003. Bechtel Hanford, Inc., FY03 ERDF Baseline To-go Update, Richland Environmental Restoration Project; Estimate Presentation, Management Review. [file "FY 03 ERDF BL Estimate Presentation.DOC" with Attachment 1 "ERDF Quantities", Attachment 2 "Total ERDF Annual To Go Costs", and Attachment 3 "FY 2003 Baseline (Outyears FY03 - FY46).] Bechtel Hanford, Inc., Richland, Washington.

BHI. 2003b. March 25, 2003. TPA Quarterly Review, Richland Environmental Restoration Project. Bechtel Hanford, Inc., Richland, Washington.

CERCLA - Comprehensive Environmental Response, Compensation, and Liability Act. 1980. Public Law 96-150, as amended, 94 Stat. 2767, 42 USC 9601 et seq.

Clark SW, SW Callison, and TM Blakley. 2003. "Risk Assessment for the Fast Flux Test Facility Entombment Option.” CH2M HILL, Richland Office, Richland, Washington, in York, MT, 2005. Technical Information Document for the Fast Flux Test Facility Closure Project Environmental Impact Statement. FFTF-18346, Rev.1. Fluor Hanford Inc., Richland, Washington.

Coony FM. 2002. Methods Used to Assemble Site-Specific Waste Site Inventories for the Initial Assessment. BHI-1570, Rev 0, Bechtel Hanford Inc., Richland, Washington.

Corbin RA, BC Simpson, MJ Anderson, WF Danielson, III, JG Field, TE Jones, and CT Kincaid. 2005. Hanford Soil Inventory Model, Rev. 1. RPP-26744, Rev. 0 and PNNL-15367, CH2M HILL Hanford Group, Inc., Richland, Washington. 
Covey LI. 2004. Waste Encapsulation and Storage Facility (WESF) Documented Safety Analysis. HNF-8758, Rev 0C, Fluor Hanford, Inc., Richland, Washington.

Diediker LP. 1999. Radionuclide Inventories of Liquid Waste Disposal Sites on the Hanford Site. HNF-1744, Fluor Daniel Hanford, Inc., Richland, Washington.

Dirkes RL and RW Hanf. 1995. Hanford Site Environmental Report for Calendar Year 1994. PNL-10574, Pacific Northwest Laboratory, Richland, Washington.

Dirkes RL and RW Hanf. 1996. Hanford Site Environmental Report for Calendar Year 1995. PNL-11139, Pacific Northwest Laboratory, Richland, Washington.

Dirkes RL and RW Hanf. 1997. Hanford Site Environmental Report for Calendar Year 1996. PNL-11472, Pacific Northwest Laboratory, Richland, Washington.

Dirkes RL, RW Hanf, RK Woodruff, and RE Lundgren. 1994. Hanford Site Environmental Report for Calendar Year 1993. PNL-9823, Pacific Northwest Laboratory, Richland, Washington.

Dodd EN, III. 1999a. Plutonium Uranium Extraction (PUREX) End State Basis for Interim Operation (BIO) for Surveillance and Maintenance. HNF-SD-CP-ISB-004, Rev. 0, B\&W Hanford Company for Fluor Daniel Hanford, Richland, Washington.

Dodd EN, III. 1999b. PUREX Deactivated End-State Hazard Analysis. HNF-SD-CP-HIE-004, Rev. 0, B\&W Hanford Company for Fluor Daniel Hanford, Richland, Washington.

DOE. 1989. Draft Environmental Impact Statement: Decommissioning of Eight Surplus Production Reactors at the Hanford Site, Richland, Washington. DOE/EIS-0119D, U.S. Department of Energy, Washington, D.C.

DOE. 1994. Remedial Investigation and Feasibility Study Report for the Environmental Restoration Disposal Facility. DOE/RL-93-99, Rev. 1, U.S. Department of Energy, Richland, Washington.

DOE. 1996. Final Environmental Impact Statement Plutonium Finishing Plant Stabilization. EIS-0244F, U.S. Department of Energy, Richland, Washington.

DOE. 1998a. Accelerating Cleanup Paths to Closure. DOE/EM-0362, U.S. Department of Energy, Office of Environmental Management, Washington D.C.

DOE. 1998b. Screening Assessment and Requirements for a Comprehensive Assessment: Columbia River Comprehensive Impact Assessment. DOE/RL-96-16, Rev. 1, U.S. Department of Energy, Richland, Washington.

DOE. 1999a. Radioactive Waste Management Manual. DOE M 435.1-1, U.S. Department of Energy, Washington, D.C.

DOE. 1999b. Implementation Guide for Use with DOE M 435.1-1. DOE G 435.1-1, U.S. Department of Energy, Washington, D.C. 
DOE. 1999c. DOE Order 435.1 Radioactive Waste Management. U.S. Department of Energy, Washington D.C.

DOE. 2001. Hanford Immobilized Low-Activity Waste Performance Assessment: 2001 Version. DOE/ORP-2000-24, Rev. 0 (formerly DOE/RL/97-69), U.S. Department of Energy, Office of River Protection, Richland, Washington.

DOE. 2005a. 2004 Annual Status Report for the Composite Analysis of Low-Level Disposal in the Central Plateau at the Hanford Site. DOE/RL-2005-58, U.S. Department of Energy, Richland, Washington.

DOE. 2005b. Hanford Site End State Vision. DOE/RL-2005-57, U.S. Department of Energy, Richland, Washington.

DOE/RL. 2005c. Internet, http://www.hanford.gov/rl/uploadfiles/10025_pie.pdf, 5/5/05.

DSHS. 1987. Special Investigation Report by the Department of Social and Health Services Iodine-129 Task Force (Task Force: D Peterson, A Conklin, A Jeffries, L Melby, and G Ziegler), Department of Social and Health Services, State of Washington, Olympia, Washington.

Ecology - Washington State Department of Ecology, U.S. Environmental Protection Agency, and U.S. Department of Energy. 1989. Hanford Federal Facility Agreement and Consent Order. Document No. 89-10, as amended (The Tri-Party Agreement), Olympia, Washington.

EPA. 1998. Guidelines for Ecological Risk Assessment. EPA/630/R-95/002F, Risk Assessment Forum, U.S. Environmental Protection Agency, Washington, D.C. (also published as Federal Register 63(93):26846-26924).

Field JG and TE Jones. 2005. Tank Farm Vadose Zone Contaminant: Volume Estimates for Risk Assessments. RPP-23405, Rev. 1, CH2M HILL Hanford Group, Inc., Richland, Washington.

Firestone M, P Fenner-Crisp, T Barry, D Bennet, S Chang, M Callahan, A Burke, J Michaud, M Olsen, P Cirone, D Barnes, WP Wood, and SM Knott. 1997. Guiding Principles for Monte Carlo Analysis, EPA/630/R-97/001, Risk Assessment Forum, U.S. Environmental Protection Agency, Washington, D.C.

Fix JJ. 1975. Environmental Surveillance at Hanford for CY-1974. BNWL 1910. Battelle-Northwest Laboratory, Richland, Washington.

Fix JJ and PJ Blumer. 1975. Environmental Surveillance at Hanford for CY-1974 Data (Addendum). BNWL 1910ADD, Battelle-Northwest Laboratory, Richland, Washington.

Fix JJ, PJ Blumer, GR Hoenes and PE Bramson. 1977. Environmental Surveillance at Hanford for CY 1976. BNWL-2124, Battelle-Northwest Laboratory, Richland, Washington.

FHI. 2001. Nuclear Material Mass Flow and Accountability on the Hanford Site. HNF-8069, Fluor Hanford, Inc., Richland, Washington. 
FHI. 2004. Plan for Central Plateau Closure. CP-22319-DEL, Rev. 0, Fluor Hanford, Inc., Richland, Washington.

Fritz, LL, CK Girres, JJ Lang and TJ DeForest. 2003. Hanford Site Solid Waste Management Environmental Impact Statement Technical Information Document, HNF-4755, Rev. 1, Fluor Hanford, Inc., Richland, Washington.

Gydesen SP. 1993. Fuel-Element Failure in Hanford Single-Pass Reactors 1944-1971. PNWD-2161 HEDR, prepared for the Technical Steering Panel and the Centers for Disease Control and Prevention by Battelle, Pacific Northwest Laboratory, Richland, Washington.

H\&R Technical Associates and NR Kerr. 2000. U Plant Facility Safety Analysis Report. BHI-01157, Rev. 2, Bechtel Hanford, Inc., Richland, Washington.

Hanson GL, JD Anderson, GR Kiel, BJ McMurray, and NP Nisick. 1973. Input and Decayed Values of Radioactive Solid Wastes Buried in the 200 Areas Through 1971. ARH-2762, Atlantic Richfield Hanford Company, Richland, Washington.

Hartman MJ, LF Morasch, and WD Webber (eds.). 2003. Hanford Groundwater Monitoring for Fiscal Year 2002. PNNL-14187, Pacific Northwest National Laboratory, Richland, Washington.

Hedengren DC. 1985. ORIGEN2 Predictions of N Reactor Fuel Fission Product Composition. SD-CP-TI-77, Rev. 0, Rockwell Hanford Operations, Richland, Washington.

Heeb CM and SP Gydesen. 1994. Sources of Secondary Radionuclide Releases from Hanford Operations. PNWD-2254 HEDR, Battelle Pacific Northwest Laboratories, Richland, Washington.

Heeb CM. 1994. Radionuclide Releases to the Atmosphere from Hanford Operations, 1944-1972. PNWD-2222 HEDR, Battelle Pacific Northwest Laboratories, Richland Washington.

Heeb CM. 1993. File: STRRMrup.625, Received 1/16/2003. Background information for Radionuclide Releases to the Columbia River from Hanford Operations, 1944-1971. PNWD-2233 HEDR, Battelle, Pacific Northwest Laboratory, Richland, Washington.

Heeb CM and DJ Bates. 1994. Radionuclide Releases to the Columbia River from Hanford Operations, 1944-1971. PNWD-2233 HEDR, prepared for the Technical Steering Panel and the Centers for Disease Control and Prevention by Battelle, Pacific Northwest Laboratory, Richland, Washington.

Higley BA, DE Place, RA Corbin, and BC Simpson. 2004. Hanford Defined Waste ModelRevision 5.0. RPP-19822, Rev. 0, CH2M HILL Hanford Group, Inc., Richland, Washington.

Houston JR and PJ Blumer. 1978. Environmental Surveillance at Hanford for CY 1977. PNL-2614, Pacific Northwest Laboratory, Richland, Washington.

Houston JR and PJ Blumer. 1979. Environmental Surveillance at Hanford for CY 1978. PNL-2932, Pacific Northwest Laboratory, Richland, Washington. 
Houston JR and PJ Blumer. 1980. Environmental Surveillance at Hanford for CY 1979. PNL-3283, Pacific Northwest Laboratory, Richland, Washington.

Jaquish RE and PJ Mitchell. 1988. Environmental Monitoring at Hanford for 1987. PNL-6464, Pacific Northwest Laboratory, Richland, Washington.

Jaquish RE and RW Bryce. 1989. Hanford Site Environmental Report for Calendar Year 1988. PNL-6825, Pacific Northwest Laboratory, Richland, Washington.

Jaquish RE and RW Bryce. 1990. Hanford Site Environmental Report for Calendar Year 1989. PNL-7346, Pacific Northwest Laboratory, Richland, Washington.

Kerr NR, H\&R Technical Associates, and MH Chew \& Associates. 2000. REDOX Facility Safety and Analysis Report. BHI-01142, Rev. 2, Bechtel Hanford, Inc., Richland, Washington.

Kerr NR. 2000. 224-B Facility Safety Analysis Report. BHI-01156, Rev. 0, Bechtel Hanford, Inc., Richland, Washington.

Kincaid CT, RW Bryce, and JW Buck. 2004. Technical Scope and Approach for the 2004 Composite Analysis of Low-Level Waste Disposal at the Hanford Site. PNNL-14372, Pacific Northwest National Laboratory, Richland, Washington.

Kincaid CT, MP Bergeron, CR Cole, MD Freshley, NL Hassig, VG Johnson, DI Kaplan, RJ Serne, GP Streile, DL Strenge, PD Thorne, LW Vail, GA Whyatt, and SK Wurstner. 1998. Composite Analysis for Low-Level Waste Disposal in the 200-Area Plateau of the Hanford Site. PNNL-11800, Pacific Northwest National Laboratory, Richland, Washington.

Kirkbride RA, PJ Certa, TM Hohl, AM Johnson, and RS Wittman. 2005. Hanford Tank Waste Operations Simulator Model Data Package for the Development Run for the Refined Target Case. RPP-RPT-23412, Revision 0A, CH2M HILL Hanford Group, Inc., Richland, Washington.

Kupfer MJ, AL Boldt, BA Higley, KM Hodgson, LW Shelton, BC Simpson, RA Watrous, MD LeClair, GL Borsheim, RT Winward, RM Orme, NG Colton, SL Lambert, DE Place, and WW Schulz. 1997. Standard Inventories of Chemicals and Radionuclides in Hanford Site Tank Wastes. HNF-SD-WMTI-740, Rev. 0, Lockheed Martin Hanford Corporation, Richland, Washington.

Last GV, WE Nichols, and CT Kincaid. 2006. Geographic and Operational Site Parameters List (GOSPL) for Hanford Assessments. PNNL-14725, Rev 1, Pacific Northwest National Laboratory, Richland, Washington.

Maxfield HL. 1979. Handbook 200 Area Waste Sites. RHO-CD-673, Volumes 1, 2, and 3, Rockwell Hanford Operations, Richland, Washington.

McConnon D. 1962. The Status of Gaseous Effluent Monitoring at HAP December 1961. HW-69205 REV, General Electric Company, Hanford Atomic Products Operation, Richland, Washington. 
Napier BA. 1991. Selection of Dominant Radionuclides for Phase 1 of the Hanford Environmental Dose Reconstruction Project. PNL-7231 HEDR, prepared for the Technical Steering Panel by Battelle, Pacific Northwest Laboratory, Richland, Washington.

Napier BA. 1992. Determination of Radionuclides and Pathways Contributing to Cumulative Dose. BN-SA-3673 HEDR, Battelle Pacific Northwest Laboratories, Richland, Washington.

Napier BA. 2000. File: Fuel Failure.xls. Size: 35 KB. Date 3/22/2000. (file received by RL Aaberg 1/23/2003). Background information for Napier et al 1999. "Inventory Scoping Study for the System Assessment Capability," Groundwater / Vadose Integration Project. June, 1999.

Nees WL and JP Corley. 1974a. Environmental Surveillance at Hanford for CY-1973. BNWL 1811, Battelle-Northwest Laboratory, Richland, Washington.

Nees WL and JP Corley. 1974b. Environmental Surveillance at Hanford for CY-1973 Data. BNWL 1811(ADD), Battelle-Northwest Laboratory, Richland, Washington.

Packer MJ. 1999. 105-K Basin Material Design Feed Description for Spent Nuclear Fuel Project Facilities, Volume 1, Fuel. HNF-SD-SNF-TI-009, Volume 1, Rev. 3, Numatec Hanford Inc., Richland, Washington.

Pearce KL. 2000. 105-K Basin Material Design Basis Feed Description for Spent Nuclear Fuel Project Facilities, Volume 2, Sludge. HNF-SD-SNF-TI-009, Revision 3, Volume 2, Fluor Hanford, Inc., Richland, Washington.

PNL. 1987. Environmental Monitoring at Hanford for 1986. PNL-6120, Pacific Northwest Laboratory, Richland, Washington.

Poston TM, RW Hanf, RL Dirkes, and LF Morasch (eds.). 2002. Hanford Site Environmental Report for Calendar Year 2001. PNNL-13910, Pacific Northwest National Laboratory, Richland, Washington.

Price KR. 1986. Environmental Monitoring at Hanford for 1985. PNL-5817, Pacific Northwest Laboratory, Richland, Washington.

Price KR, JMV Carlile, RL Dirkes, and MS Trevathan. 1984. Environmental Surveillance at Hanford for CY 1983. PNL-5038, Pacific Northwest Laboratory, Richland, Washington.

Price KR, JMV Carlile, RL Dirkes, RE Jaquish, MS Trevathan, and RK Woodruff. 1985. Environmental Monitoring at Hanford for 1984. PNL-5407, Pacific Northwest Laboratory, Richland, Washington.

Price KR, JMV Carlile, RL Dirkes, RE Jaquish, MS Trevathan, and RK Woodruff. 1986. Environmental Monitoring at Hanford for 1984 Supplement. PNL-5407 Suppl, Pacific Northwest Laboratory, Richland, Washington.

Puigh RJ and MI Wood. 2005. Inventory Data Package for the 2005 Integrated Disposal Facility Performance Assessment. RPP-20692, Rev. 1, CH2M HILL Hanford Group, Inc., Richland, Washington. 
Reddick J. 1993. Estimate of PUREX Plant Inventory of Chemicals and Radioactivity. Letter Report to Westinghouse Hanford Company (D Washenfelder), Los Alamos Technical Associates, Richland, Washington.

Reilly MA. 1998. Spent Nuclear Fuel Project Technical Databook. HNF-SD-SNF-TI-015, Rev. 6, Fluor Daniel Hanford, Richland, Washington.

RHO. 1985. Hanford Defense Waste Disposal Alternatives: Engineering Support Data for the Hanford Defense Waste - Environmental Impact Statement. RHO-RE-ST-30P, Rockwell Hanford Operations, Richland, Washington.

Schwehr BA. 1999. B Plant Surveillance and Maintenance Phase Safety Analysis Report. HNF-3358, Rev. 0, B\&W Hanford Company for Fluor Daniel Hanford, Richland, Washington.

Simmons FM. 1999. Documentation of Remaining Hazardous Substances/Dangerous Wastes in B Plant. HNF-3208, Rev. 0A, B\&W Hanford Company for Fluor Daniel Hanford, Richland, Washington.

Simpson BC, RA Corbin, and SF Agnew. 2001. Hanford Soil Inventory Model. BHI-01496, Rev. 0, Bechtel Hanford, Inc., Richland, Washington.

Smith DK. 1998. Closeout of End Point 00.00.26, "Remaining Hazardous Substances/Dangerous Waste Documentation," File No. or Ref.: 16D00-98-DKS-078. B\&W Hanford Company, Richland, Washington.

Speer DR, JJ Fix, and PJ Blumer. 1976. Environmental Surveillance at Hanford for CY 1975. BNWL-1979, Battelle-Northwest Laboratory, Richland, Washington.

Stenner RD, KH Cramer, KA Higley, SJ Jette, DA Lamar, TJ McLaughlin, DR Sherwood, and NC Van Houten. 1988. Hazard Ranking System Evaluation of CERCLA Inactive Waste Sites at Hanford (Volume 1 - Evaluation Methods and Results, Volume 2 - Engineered-Facility Sites \{HISS Data Base\} Volume 3 Unplanned-Release Sites \{HISS Data Base\}). PNL-6456, Vol 1, 2, and 3, Pacific Northwest Laboratory, Richland, Washington.

Sula MJ and PJ Blumer. 1981. Environmental Surveillance at Hanford for CY 1980. PNL-3728, Pacific Northwest Laboratory, Richland, Washington.

Sula MJ, JMV Carlile, KR Price, and WD McCarmack. 1983. Environmental Surveillance at Hanford for CY 1982. PNL-4657, Pacific Northwest Laboratory, Richland, Washington.

Sula MJ, WD McCormack, RL Dirkes, KR Price, and PA Eddy. 1982. Environmental Surveillance at Hanford for CY 1981. PNL-4221, Pacific Northwest Laboratory, Richland, Washington.

Templeton KJ and LL Dirks. 1995. Solid Low-Level Waste Forecasting Guide. PNL-10487, Pacific Northwest Laboratory, Richland, Washington.

Washington State Department of Health and Washington State Department of Ecology. 2004. Final Environmental Impact Statement Commercial Low-Level Radioactive Waste Disposal Site Richland, Washington. DOH Publication 320-031, Washington State Department of Health, Olympia, Washington. 
Watrous RA and DW Wootan. 1997. Activity of Fuel Batches Processed Through Hanford Separations Plants, 1944 Through 1989. HNF-SD-WM-TI-794, Rev. 0, Lockheed Martin Hanford Corporation, Richland, Washington.

WHC. 1990. Hanford Site Stream-Specific Reports. WHC-EP-0342 (report and 33 stream-specific addenda), Westinghouse Hanford Company, Richland, Washington.

Wintczak TM. May 5, 2003, e-mail to CT Kincaid, Subject "To tonnage.xls" with attached file "To tonnage.xls"

Wittekind WD, SP Roblyer, and H Toffer. 1999. Shippingport Pressurized Water Reactor Core 2 Blanket Assemblies Source Term Calculations Using ORIGEN2. HNF-SD-SNF-TI-061, Rev. 1, Fluor Daniel Northwest, Richland, Washington.

Woodruff RK, RW Hanf, and RE Lundgren. 1992. Hanford Site Environmental Report for Calendar Year 1991. PNL-8148, Pacific Northwest Laboratory, Richland, Washington.

Woodruff RK, RW Hanf, and RE Lundgren. 1993. Hanford Site Environmental Report for Calendar Year 1992. PNL-8682, Pacific Northwest Laboratory, Richland, Washington.

Woodruff RK, RW Hanf, MG Hefty, and RE Lundgren. 1991. Hanford Site Environmental Report for Calendar Year 1990. PNL-7930, Pacific Northwest Laboratory, Richland, Washington.

Wootan DW and SF Finfrock. 2002. Activity of Fuel Batches Processed Through Hanford Separations Plants, 1944 through 1989. RPP-13489, Revision 0, CH2M HILL Hanford Group, Inc., Richland, Washington.

York MT. 2005. Technical Information Document for the Fast Flux Test Facility Closure Project Environmental Impact Statement. FFTF-18346, Rev. 1, Fluor Hanford, Richland, Washington. 


\section{Appendix A}

\section{Remedial Actions and Completion Dates}




\section{Appendix A}

\section{Remedial Actions and Completion Dates}

This appendix presents the current baseline information of remedial action and completion date for each waste site under consideration. It is based on information made available by the U.S. Department of Energy (DOE) and its contractors and on final and interim records of decision. Remedial actions and schedule data for river corridor waste sites was drawn (1) from the March 25, 2003, Tri-Party (TPA) Quarterly Review (BHI 2003a, 2003b), (2) a listing of site and facilities from the Environmental Restoration Contractor FY 2003 Baseline (e-mail from J LaPierre ${ }^{1}$ ), and (3) a calendar listing of Environmental Restoration Disposal Facility (ERDF) disposal tonnages from operational areas (e-mail from TM Wintczak ${ }^{2}$ ). Remedial action and schedule data for Central Plateau waste sites was drawn from (1) the Plan for Central Plateau Closure (FHI 2004) and (2) files containing remedy and closure zone dates provided by DOE Richland Operations Office staff (e-mail from RD Hildebrand; ${ }^{3}$ e-mail from R Holten ${ }^{4}$.

\section{References}

BHI. 2003a. January 30, 2003. Bechtel Hanford, Inc., FY03 ERDF Baseline To-go Update, Richland Environmental Restoration Project; Estimate Presentation, Management Review. [file "FY 03 ERDF BL Estimate Presentation.DOC" with Attachment 1 "ERDF Quantities," Attachment 2 "Total ERDF Annual To Go Costs," and Attachment 3 "FY 2003 Baseline (Outyears FY03 - FY46).”]

BHI. 2003b. March 25, 2003. TPA Quarterly Review, Richland Environmental Restoration Project. Bechtel Hanford, Inc., Richland, Washington,

\footnotetext{
${ }^{1}$ LaPierre, J (Bechtel Hanford, Inc., Richland, Washington). April 28, 2003, e-mail to CT Kincaid (Pacific Northwest National Laboratory, Richland, Washington), Subject: Site \& Facility Listing from FY03 Update Database with attached file Special List 4-28-03.

${ }^{2}$ Wintczak TM (Bechtel Hanford, Inc., Richland, Washington). May 5, 2003, e-mail to CT Kincaid (Pacific Northwest National Laboratory, Richland, Washington), Subject: To tonnage.xls with attached file, To tonnage.xls.

${ }^{3}$ Hildebrand RD (U.S. Department of Energy, Richland, Washington). July 8, 2005, e-mail to CT Kincaid (Pacific Northwest National Laboratory, Richland, Washington). Subject: FW: files on Central Plateau with attached files. Contained e-mail from RA Holten to RD Hildebrand, dated July 7, 2005. Subject: Files on Central Plateau with attached files:

All_WIDS_Review_for_CPCP_update.xls, Zone Locations.xls, Zone number to MII file crosswalk.xls, and Summary of Dates.xls

${ }^{4}$ Holten RA (U.S. Department of Energy, Richland, Washington). July 7, 2005, e-mail to CT Kincaid (Pacific Northwest National Laboratory, Richland, Washington). Subject: RE: ET caps and ET mono caps; Remedial action dates.
} 
REMEDIAL ACTION \& COMPLETION DATES

USES JANUARY 6, 2006 HANFORD ASSESSMENTS SITE LIST CENTRAL PLATEAU WASTE SITES

\begin{tabular}{|c|c|c|c|c|}
\hline WIDS Site Code & Zone & $\begin{array}{l}\text { mpleti } \\
\text { Date }\end{array}$ & Remedy & Notes \\
\hline 200-A_TEDF & 200-E Ponds Zone & 2032 & No Action & \\
\hline 200-E-100 & B Plant Zone & 2022 & No Action & \\
\hline 200-E-102 & Purex Zone & 2021 & ABAR2E10/PUREX & ABAR2E10/ET-Mono \\
\hline 200-E-103 & Purex Zone & 2021 & ABAR2E10/PUREX & ABAR2E10/ET-Mono \\
\hline 200-E-106 & IDF Zone & 2035 & No Action & \\
\hline 200-E-107 & Purex Zone & 2021 & ABAR2E10/PUREX & ABAR2E10/ET-Mono \\
\hline 200-E-115 & WTP/A Farm Zone & 2034 & RTD & 1 \\
\hline 200-E-117 & B Plant Zone & 2022 & RTD & 1 \\
\hline 200-E-121 & B Farm Zone & 2026 & RTD & 1 \\
\hline 200-E-122 & B Plant Zone & 2022 & RTD & 1 \\
\hline 200-E-123 & Solid Waste Zone & 2027 & RTD & 1 \\
\hline 200-E-124 & Purex Zone & 2021 & RTD & \\
\hline 200-E-125 & Purex Zone & 2021 & RTD & \\
\hline 200-E-126 & 200-E Ponds Zone & 2016 & No Action & MESC/MNA/IC \\
\hline 200-E-127 & 200-E Ponds Zone & 2016 & No Action & MESC/MNA/IC \\
\hline $200-E-128$ & Solid Waste Zone & 2027 & RTD & 1 \\
\hline 200-E-129 & B Plant Zone & 2022 & RTD & 1 \\
\hline 200-E-130 & B Plant Zone & 2022 & RTD & 1 \\
\hline 200-E-136 & Purex Zone & 2021 & D\&D / ET Cap & Closed out as part of completion of 202A \\
\hline 200-E-25 & B Plant Zone & 2022 & RTD & 1 \\
\hline 200-E-28 & B Plant Zone & 2022 & D\&D / ET Cap & Closed out as part of completion of 221B \\
\hline $200-E-4$ & Semi-Works Zone & 2017 & RTD & 1 \\
\hline $200-E-41$ & Semi-Works Zone & 2017 & D\&D / ET Cap & Closed out as part of Semi-Works \\
\hline $200-E-44$ & Purex Zone & 2021 & No Action & Close out as part of $202 \mathrm{~A}$ \\
\hline 200-E-5 & 200-E Admin Zone & 2024 & No Action & \\
\hline $200-E-55$ & B Plant Zone & 2022 & ABAR w/ B Plant & ET Cap \\
\hline $200-E-56$ & Semi-Works Zone & 2017 & ABAR2E17 w/ Semi Wks & ET Cap \\
\hline $200-E-57$ & Semi-Works Zone & 2017 & RTD & 1 \\
\hline $200-E-60$ & B Farm Zone & 2026 & RTD/ABAR w/ B-BX-BY WMA & ET Cap \\
\hline 200-E-61 & Purex Zone & 2021 & ABAR2E10/PUREX & ABAR2E10/ET-Mono \\
\hline $200-E-62$ & Purex Zone & 2021 & No Action & \\
\hline 200-E-63 & Purex Zone & 2021 & No Action & \\
\hline $200-E-64$ & Purex Zone & 2021 & No Action & \\
\hline 200-E-65 & Purex Zone & 2021 & No Action & \\
\hline 200-E-67 & Purex Zone & 2021 & ABAR2E10/PUREX & ABAR2E10/ET-Mono \\
\hline 200-E-68 & Purex Zone & 2021 & No Action & \\
\hline 200-E-69 & Purex Zone & 2021 & No Action & \\
\hline $200-E-7$ & 200-E Admin Zone & 2024 & No Action & \\
\hline 200-E-70 & Purex Zone & 2021 & No Action & \\
\hline 200-E-71 & Purex Zone & 2021 & No Action & \\
\hline 200-E-72 & Purex Zone & 2021 & No Action & \\
\hline 200-E-73 & Purex Zone & 2021 & No Action & \\
\hline 200-E-74 & Purex Zone & 2021 & No Action & \\
\hline 200-E-75 & Purex Zone & 2021 & No Action & \\
\hline 200-E-76 & Purex Zone & 2021 & No Action & \\
\hline 200-E-77 & Purex Zone & 2021 & No Action & \\
\hline 200-E-78 & Purex Zone & 2021 & No Action & \\
\hline 200-E-79 & Purex Zone & 2021 & No Action & \\
\hline 200-E-80 & Purex Zone & 2021 & No Action & \\
\hline 200-E-81 & Purex Zone & 2021 & No Action & \\
\hline 200-E-82 & 200-E Admin Zone & 2024 & No Action & \\
\hline 200-E-84 & Purex Zone & 2021 & No Action & \\
\hline 200-E-85 & Purex Zone & 2021 & ABAR2E10/PUREX & ABAR2E10/ET-Mono \\
\hline 200-E-88 & B Plant Zone & 2022 & No Action & \\
\hline 200-E-89 & B Plant Zone & 2022 & No Action & \\
\hline 200-E-9 & 200-E Admin Zone & 2024 & No Action & \\
\hline 200-E-90 & B Plant Zone & 2022 & No Action & \\
\hline 200-E-91 & B Plant Zone & 2022 & No Action & \\
\hline 200-E-92 & B Plant Zone & 2022 & No Action & \\
\hline 200-E-93 & B Plant Zone & 2022 & No Action & \\
\hline 200-E-94 & B Plant Zone & 2022 & No Action & \\
\hline 200-E-95 & B Plant Zone & 2022 & No Action & \\
\hline 200-E-97 & B Plant Zone & 2022 & No Action & \\
\hline
\end{tabular}




\begin{tabular}{|c|c|c|c|c|}
\hline & & mpleti & & \\
\hline WIDS site Code & Zone & Date & Remedy & Notes \\
\hline 200-E-98 & B Plant Zone & 2022 & No Action & \\
\hline 200-E-99 & B Plant Zone & 2022 & No Action & \\
\hline $200-W-104$ & U Plant Zone & 2016 & RTD & Close out as part of $2714 \mathrm{U}$ \\
\hline $200-W-15$ & REDOX Zone & 2030 & ABAR $w /$ REDOX & ET Cap \\
\hline $200-W-20$ & T Plant Zone & 2033 & D\&D / ET Cap & Closed out as part of completion of $221 \mathrm{~T}$ \\
\hline $200-W-22$ & REDOX Zone & 2030 & RTD & 1 \\
\hline $200-W-42$ & U Plant Zone & 2016 & RTD & 1 \\
\hline $200-W-52$ & T Farm Zone & 2031 & ABAR2W03/T WMA & ET Cap \\
\hline $200-W-67$ & S/U Farm Zone & 2028 & No Action & MESC/MNA/IC \\
\hline $200-W-69$ & REDOX Zone & 2030 & D\&D / ET Cap & Closed out as part of completion of $222 \mathrm{~S}$ \\
\hline $200-W-76$ & REDOX Zone & 2030 & D\&D / ET Cap & Closed out as part of completion of $222 \mathrm{~S}$ \\
\hline $200-W-83$ & T Plant Zone & 2017 & RTD & 1 \\
\hline $200-W-85$ & U Plant Zone & 2016 & RTD & 1 \\
\hline $200-W-86$ & T Plant Zone & 2017 & No Action & MESC/MNA/IC \\
\hline $200-W-87$ & U Plant Zone & 2016 & RTD & 1 \\
\hline $200-W-9$ & T Plant Zone & 2033 & ABAR w/ T Plant & ET Cap \\
\hline $200-W-90$ & T Farm Zone & 2031 & ABAR2W03/T WMA & ET Cap \\
\hline 202-A-WS-1 & Purex Zone & 2021 & D\&D / ET Cap & Closed out as part of completion of 202A \\
\hline 203-S_\%_205-S & REDOX Zone & 2030 & RTD & Close out as part of REDOX \\
\hline 207-A-NŌRTH & 200-E Ponds Zone & 2016 & No Action & MESC/MNA/IC \\
\hline 207-A-SOUTH & 200-E Ponds Zone & 2016 & No Action & MESC/MNA/IC \\
\hline 207-B & Solid Waste Zone & 2027 & RTD & 1 \\
\hline 207-S & 200-W Ponds Zone & 2016 & IBAR & ET Cap \\
\hline $207-\mathrm{T}$ & T Farm Zone & 2031 & RTD & 1 \\
\hline $207-U$ & T Plant Zone & 2017 & No Action & MESC/MNA/IC \\
\hline $207-Z$ & PFP Zone & 2017 & ABAR2W07/PFP & ET Cap \\
\hline 209-E-WS-2 & Semi-Works Zone & 2017 & RTD & 1 \\
\hline 213-W & WM Zone & 2023 & $\mathrm{D \& D}$ & Closed out as part of completion of $213 \mathrm{~W}$ \\
\hline $216-A-1$ & 200-E Ponds Zone & 2016 & ABAR2E08 & ET Cap \\
\hline $216-A-10$ & Purex Zone & 2021 & IBAR & ET Cap \\
\hline $216-A-11$ & Purex Zone & 2021 & ABAR2E10/PUREX & ABAR2E10/ET-Mono \\
\hline $216-A-12$ & Purex Zone & 2021 & ABAR2E10/PUREX & ABAR2E10/ET-Mono \\
\hline $216-A-13$ & Purex Zone & 2021 & ABAR2E10/PUREX & ABAR2E10/ET-Mono \\
\hline $216-A-14$ & Purex Zone & 2021 & ABAR2E10/PUREX & ABAR2E10/ET-Mono \\
\hline 216-A-15 & Purex Zone & 2021 & ABAR2E10/PUREX & ABAR2E10/ET-Mono \\
\hline $216-A-16$ & WTPIA Farm Zone & 2034 & ABAR W/ A-AN-AX-AY-AZ WMA & ET Cap \\
\hline $216-A-17$ & WTPIA Farm Zone & 2034 & ABAR w/ A-AN-AX-AY-AZ WMA & ET Cap \\
\hline $216-A-18$ & 200-E Ponds Zone & 2016 & IBAR & ET Cap \\
\hline 216-A-19 & 200-E Ponds Zone & 2016 & ABAR2E09 & ET Cap \\
\hline $216-A-2$ & Purex Zone & 2021 & ABAR2E10/PUREX & ABAR2E10/ET-Mono \\
\hline $216-A-20$ & 200-E Ponds Zone & 2016 & ABAR2E09 & ET Cap \\
\hline $216-A-21$ & Purex Zone & 2021 & ABAR2E10/PUREX & ABAR2E10/ET-Mono \\
\hline $216-A-22$ & Purex Zone & 2021 & RTD & \\
\hline $216-A-23 A$ & WTPIA Farm Zone & 2034 & ABAR w/ A-AN-AX-AY-AZ WMA & ET Cap \\
\hline 216-A-23B & WTP/A Farm Zone & 2034 & ABAR w/ A-AN-AX-AY-AZ WMA & ET Cap \\
\hline $216-A-24$ & 200-E Ponds Zone & 2016 & IBAR & ET Cap \\
\hline $216-A-25$ & 200-E Ponds Zone & 2016 & No Action & MESC/MNA/IC \\
\hline 216-A-26 & Purex Zone & 2021 & ABAR2E10/PUREX & ABAR2E10/ET-Mono \\
\hline $216-A-26 A$ & Purex Zone & 2021 & ABAR2E10/PUREX & ABAR2E10/ET-Mono \\
\hline $216-A-27$ & Purex Zone & 2021 & IBAR & ET Cap \\
\hline $216-A-28$ & Purex Zone & 2021 & RTD & \\
\hline 216-A-29 & 200-E Ponds Zone & 2016 & No Action & MESC/MNA/IC \\
\hline $216-A-3$ & Purex Zone & 2021 & RTD & \\
\hline $216-A-30$ & Purex Zone & 2021 & IBAR & $\begin{array}{l}\text { Change ABAR with } 216-A-30 \text { add } 50,000 \text { sf - } \\
\text { ET Mono }\end{array}$ \\
\hline $216-A-31$ & Purex Zone & 2021 & ABAR2E10/PUREX & ABAR2E10/ET-Mono \\
\hline $216-A-32$ & Purex Zone & 2021 & IBAR & ET Cap \\
\hline $216-A-33$ & Purex Zone & 2021 & ABAR2E10/PUREX & ABAR2E10/ET-Mono \\
\hline $216-A-34$ & 200-E Ponds Zone & 2016 & ABAR2E09 & ET Cap \\
\hline 216-A-35 & Purex Zone & 2021 & ABAR2E10/PUREX & ABAR2E10/ET-Mono \\
\hline $216-A-36 A$ & Purex Zone & 2021 & IBAR & ET Cap \\
\hline $216-A-36 B$ & Purex Zone & 2021 & IBAR & ET Cap \\
\hline 216-A-37-1 & Purex Zone & 2021 & IBAR & ET Cap \\
\hline 216-A-37-2 & Purex Zone & 2021 & IBAR & ET Cap \\
\hline 216-A-39 & WTP/A Farm Zone & 2034 & ABAR w/ A-AN-AX-AY-AZ WMA & ET Cap \\
\hline $216-A-4$ & Purex Zone & 2021 & ABAR2E10/PUREX & ABAR2E10/ET-Mono \\
\hline
\end{tabular}




\begin{tabular}{|c|c|c|c|c|}
\hline WIDS Site Code & Zone & $\begin{array}{l}\text { mpleti } \\
\text { Date }\end{array}$ & Remedy & Notes \\
\hline $216-A-40$ & Purex Zone & 2021 & RTD & \\
\hline $216-A-41$ & Purex Zone & 2021 & RTD & \\
\hline $216-A-42$ & Purex Zone & 2021 & RTD & \\
\hline $216-A-45$ & Purex Zone & 2021 & IBAR & ET Cap \\
\hline $216-A-5$ & Purex Zone & 2021 & IBAR & ET Cap \\
\hline $216-A-6$ & Purex Zone & 2021 & IBAR & ET Cap \\
\hline $216-A-7$ & 200-E Ponds Zone & 2016 & ABAR2E08 & ET Cap \\
\hline $216-A-8$ & 200-E Ponds Zone & 2016 & IBAR & ET Cap \\
\hline $216-A-9$ & Purex Zone & 2021 & RTD & \\
\hline $216-B-10 A$ & B Plant Zone & 2022 & RTD & 1 \\
\hline 216-B-10B & B Plant Zone & 2022 & RTD & 1 \\
\hline $216-B-11 A \% B$ & B Farm Zone & 2026 & ABAR w/ B-BX-BY WMA & ET Cap \\
\hline 216-B-12 & B Plant Zone & 2022 & IBAR & ET Cap \\
\hline $216-B-13$ & B Plant Zone & 2022 & ABAR w/ B Plant & ET Cap \\
\hline 216-B-14 & NRDWL/BC Control Zone & 2009 & ABAR2E06 & ABAR-ET Mono \\
\hline 216-B-15 & NRDWL/BC Control Zone & 2009 & ABAR2E06 & ABAR-ET Mono \\
\hline $216-B-16$ & NRDWL/BC Control Zone & 2009 & ABAR2E06 & ABAR-ET Mono \\
\hline 216-B-17 & NRDWL/BC Control Zone & 2009 & ABAR2E06 & ABAR-ET Mono \\
\hline 216-B-18 & NRDWL/BC Control Zone & 2009 & ABAR2E06 & ABAR-ET Mono \\
\hline 216-B-19 & NRDWL/BC Control Zone & 2009 & ABAR2E06 & ABAR-ET Mono \\
\hline 216-B-20 & NRDWL/BC Control Zone & 2009 & ABAR2E05 & ABAR-ET Mono \\
\hline 216-B-21 & NRDWL/BC Control Zone & 2009 & ABAR2E05 & ABAR-ET Mono \\
\hline $216-B-2-1$ & Solid Waste Zone & 2027 & RTD & 1 \\
\hline 216-B-22 & NRDWL/BC Control Zone & 2009 & ABAR2E05 & ABAR-ET Mono \\
\hline $216-B-2-2$ & Solid Waste Zone & 2027 & RTD & 1 \\
\hline $216-B-23$ & NRDWL/BC Control Zone & 2009 & ABAR2E04 & ABAR-ET Mono \\
\hline $216-B-2-3$ & Solid Waste Zone & 2027 & RTD & 1 \\
\hline 216-B-24 & NRDWL/BC Control Zone & 2009 & ABAR2E04 & ABAR-ET Mono \\
\hline $216-B-25$ & NRDWL/BC Control Zone & 2009 & ABAR2E04 & ABAR-ET Mono \\
\hline 216-B-26 & NRDWL/BC Control Zone & 2009 & ABAR2E04 & ABAR-ET Mono \\
\hline $216-B-27$ & NRDWL/BC Control Zone & 2009 & ABAR2E04 & ABAR-ET Mono \\
\hline $216-B-28$ & NRDWL/BC Control Zone & 2009 & ABAR2E04 & ABAR-ET Mono \\
\hline 216-B-29 & NRDWL/BC Control Zone & 2009 & ABAR2E01 & ABAR-ET Mono \\
\hline 216-B-3 & 200-E Ponds Zone & 2016 & No Action & MESC/MNA/IC \\
\hline 216-B-30 & NRDWL/BC Control Zone & 2009 & ABAR2E01 & ABAR-ET Mono \\
\hline 216-B-31 & NRDWL/BC Control Zone & 2009 & ABAR2E01 & ABAR-ET Mono \\
\hline 216-B-3-1 & 200-E Ponds Zone & 2016 & No Action & MESC/MNA/IC \\
\hline 216-B-32 & NRDWL/BC Control Zone & 2009 & ABAR2E01 & ABAR-ET Mono \\
\hline 216-B-3-2 & 200-E Ponds Zone & 2016 & No Action & MESC/MNA/IC \\
\hline 216-B-33 & NRDWL/BC Control Zone & 2009 & ABAR2E01 & ABAR-ET Mono \\
\hline 216-B-3-3 & 200-E Ponds Zone & 2016 & No Action & MESC/MNA/IC \\
\hline 216-B-34 & NRDWL/BC Control Zone & 2009 & ABAR2E01 & ABAR-ET Mono \\
\hline 216-B-35 & B Farm Zone & 2026 & ABAR2E16 & ET Cap \\
\hline $216-B-36$ & B Farm Zone & 2026 & ABAR2E16 & ET Cap \\
\hline 216-B-37 & B Farm Zone & 2026 & ABAR2E16 & ET Cap \\
\hline 216-B-38 & B Farm Zone & 2026 & ABAR2E16 & ET Cap \\
\hline 216-B-39 & B Farm Zone & 2026 & ABAR2E16 & ET Cap \\
\hline 216-B-3A_RAD & 200-E Ponds Zone & 2016 & No Action & \\
\hline 216-B-3B_RAD & 200-E Ponds Zone & 2016 & No Action & \\
\hline 216-B-3C_RAD & 200-E Ponds Zone & 2016 & No Action & \\
\hline $216-\mathrm{B}-4$ & B Plant Zone & 2022 & ABAR w/ B Plant & ET Cap \\
\hline $216-B-40$ & B Farm Zone & 2026 & ABAR2E16 & ET Cap \\
\hline 216-B-41 & B Farm Zone & 2026 & ABAR2E16 & ET Cap \\
\hline $216-B-42$ & B Farm Zone & 2026 & ABAR2E16 & ET Cap \\
\hline 216-B-43 & B Farm Zone & 2026 & ABAR2E13 & ET Cap \\
\hline $216-B-44$ & B Farm Zone & 2026 & ABAR2E13 & ET Cap \\
\hline $216-B-45$ & B Farm Zone & 2026 & ABAR2E13 & ET Cap \\
\hline $216-B-46$ & B Farm Zone & 2026 & ABAR2E13 & ET Cap \\
\hline $216-B-47$ & B Farm Zone & 2026 & ABAR2E13 & ET Cap \\
\hline 216-B-48 & B Farm Zone & 2026 & ABAR2E13 & ET Cap \\
\hline 216-B-49 & B Farm Zone & 2026 & ABAR2E13 & ET Cap \\
\hline $216-B-5$ & B Plant Zone & 2022 & No Action & MESC/MNA/IC \\
\hline $216-B-50$ & B Farm Zone & 2026 & ABAR2E13 & ET Cap \\
\hline 216-B-51 & B Farm Zone & 2026 & No Action & MESC/MNA/IC \\
\hline 216-B-52 & NRDWL/BC Control Zone & 2009 & ABAR2E04 & ABAR-ET Mono \\
\hline 216-B-53A & NRDWL/BC Control Zone & 2009 & RTD & \\
\hline
\end{tabular}




\begin{tabular}{|c|c|c|c|c|}
\hline WIDS Site Code & Zone & $\begin{array}{l}\text { Dmpleti } \\
\text { Date }\end{array}$ & Remedy & Notes \\
\hline 216-B-53B & NRDWL/BC Control Zone & 2009 & RTD & \\
\hline 216-B-54 & NRDWL/BC Control Zone & 2009 & RTD & \\
\hline 216-B-55 & B Plant Zone & 2022 & IBAR & ET Cap \\
\hline $216-B-57$ & B Farm Zone & 1994 & IBAR & Hanford \\
\hline $216-B-58$ & NRDWL/BC Control Zone & 2009 & RTD & \\
\hline 216-B-59 & B Plant Zone & 2022 & RTD & 1 \\
\hline 216-B-59B & B Plant Zone & 2022 & RTD & 1 \\
\hline 216-B-6 & B Plant Zone & 2022 & ABAR w/ B Plant & ET Cap \\
\hline 216-B-60 & B Plant Zone & 2022 & ABAR w/ B Plant & ET Cap \\
\hline 216-B-62 & B Plant Zone & 2022 & IBAR & ET Cap \\
\hline 216-B-63 & Solid Waste Zone & 2027 & RTD & 1 \\
\hline 216-B-7A\%B & B Farm Zone & 2026 & ABAR w/ B-BX-BY WMA & ET Cap \\
\hline 216-B-8 & B Farm Zone & 2026 & IBAR & ET Cap \\
\hline $216-B-9$ & Solid Waste Zone & 2027 & IBAR & ET Cap \\
\hline 216-BY-201 & B Farm Zone & 2026 & RTD/ABAR2E13 & ET Cap \\
\hline $216-C-1$ & Semi-Works Zone & 2017 & ABAR2E17 w/ Semi Wks & ET Cap \\
\hline 216-C-10 & Semi-Works Zone & 2017 & IBAR & ET Cap \\
\hline $216-C-2$ & Semi-Works Zone & 2017 & ABAR2E17 w/ Semi Wks & ET Cap \\
\hline $216-C-3$ & Semi-Works Zone & 2017 & ABAR2E17 w/ Semi Wks & ET Cap \\
\hline $216-C-4$ & Semi-Works Zone & 2017 & ABAR2E17 w/ Semi Wks & ET Cap \\
\hline $216-C-5$ & Semi-Works Zone & 2017 & ABAR2E17 w/ Semi Wks & ET Cap \\
\hline $216-C-6$ & Semi-Works Zone & 2017 & ABAR2E17 w/ Semi Wks & ET Cap \\
\hline $216-C-7$ & Semi-Works Zone & 2017 & RTD & 1 \\
\hline $216-C-8$ & C Farm Zone & 2016 & ABAR w/ C WMA & ET Cap \\
\hline $216-C-9$ & Semi-Works Zone & 2017 & No Action & MESC/MNA/IC \\
\hline $216-N-1$ & 200-E Ponds Zone & 2016 & RTD & 1 \\
\hline $216-N-2$ & 200-E Ponds Zone & 2016 & RTD & 1 \\
\hline $216-N-3$ & 200-E Ponds Zone & 2016 & RTD & 1 \\
\hline $216-N-4$ & 200-E Ponds Zone & 2016 & RTD & 1 \\
\hline $216-N-5$ & 200-E Ponds Zone & 2016 & RTD & 1 \\
\hline $216-N-6$ & 200-E Ponds Zone & 2016 & RTD & 1 \\
\hline $216-\mathrm{N}-7$ & 200-E Ponds Zone & 2016 & RTD & 1 \\
\hline $216-N-8$ & 200-E Ponds Zone & 2016 & No Action & \\
\hline $216-S-1 \% 2$ & REDOX Zone & 2030 & IBAR & ET Cap \\
\hline 216-S-10D & 200-W Ponds Zone & 2016 & No Action & MESC/MNA/IC \\
\hline 216-S-10P & 200-W Ponds Zone & 2016 & ABAR2W11 & ET Cap \\
\hline 216-S-11 & 200-W Ponds Zone & 2016 & ABAR2W11 & ET Cap \\
\hline $216-S-12$ & REDOX Zone & 2030 & IBAR & ET Cap \\
\hline $216-S-13$ & REDOX Zone & 2030 & IBAR & ET Cap \\
\hline 216-S-14 & 200-W Ponds Zone & 2016 & RTD & 1 \\
\hline 216-S-15 & S/U Farm Zone & 2028 & ABAR w/ S-SX-SY WMA & ET Cap \\
\hline 216-S-16D & 200-W Ponds Zone & 2016 & No Action & MESC/MNA/IC \\
\hline 216-S-16P & 200-W Ponds Zone & 2016 & IBAR & ET Cap \\
\hline 216-S-17 & 200-W Ponds Zone & 2016 & ABAR2W11 & ET Cap \\
\hline 216-S-18 & S/U Farm Zone & 2028 & IBAR & ET Cap \\
\hline 216-S-19 & 200-W Ponds Zone & 2016 & RTD & 1 \\
\hline 216-S-20 & REDOX Zone & 2030 & RTD & 1 \\
\hline $216-S-21$ & 200-W Ponds Zone & 2016 & IBAR & ET Cap \\
\hline $216-S-22$ & REDOX Zone & 2030 & IBAR & ET Cap \\
\hline $216-S-23$ & S/U Farm Zone & 2028 & IBAR & ET Cap \\
\hline $216-S-25$ & 200-W Ponds Zone & 2016 & IBAR & ET Cap \\
\hline $216-S-26$ & 200-W Ponds Zone & 2016 & RTD & 1 \\
\hline $216-S-3$ & S/U Farm Zone & 2028 & ABAR w/ S-SX-SY WMA & ET Cap \\
\hline $216-S-4$ & 200-W Ponds Zone & 2016 & ABAR2W09 & ET Cap \\
\hline $216-S-5$ & 200-W Ponds Zone & 2016 & ABAR2W11 & ET Cap \\
\hline $216-S-6$ & 200-W Ponds Zone & 2016 & ABAR2W11 & ET Cap \\
\hline 216-S-7 & REDOX Zone & 2030 & IBAR & ET Cap \\
\hline $216-S-8$ & REDOX Zone & 2030 & IBAR & ET Cap \\
\hline 216-S-9 & S/U Farm Zone & 2028 & IBAR & ET Cap \\
\hline $216-S X-2$ & S/U Farm Zone & 2028 & IBAR & ET Cap \\
\hline 216-T-1 & T Plant Zone & 2017 & IBAR & ET Cap \\
\hline 216-T-10 & T Plant Zone & 2017 & ABAR2W08 & ET Cap \\
\hline 216-T-11 & T Plant Zone & 2017 & ABAR2W08 & ET Cap \\
\hline 216-T-12 & T Farm Zone & 2031 & IBAR & ET Cap \\
\hline 216-T-13 & T Farm Zone & 2031 & IBAR & ET Cap \\
\hline 216-T-14 & T Farm Zone & 2031 & ABAR2W02 & ET Cap \\
\hline
\end{tabular}




\begin{tabular}{|c|c|c|c|c|}
\hline WIDS Site Code & Zone & $\begin{array}{l}\text { mplet } \\
\text { Date }\end{array}$ & Remedy & Notes \\
\hline $216-\mathrm{T}-15$ & T Farm Zone & 2031 & ABAR2W02 & ET Cap \\
\hline 216-T-16 & T Farm Zone & 2031 & ABAR2W02 & ET Cap \\
\hline 216-T-17 & T Farm Zone & 2031 & ABAR2W02 & ET Cap \\
\hline 216-T-18 & T Farm Zone & 2031 & IBAR & ET Cap \\
\hline 216-T-19 & T Farm Zone & 2031 & RTD/ABAR w/ TX-TY WMA & ET Cap \\
\hline 216-T-2 & T Plant Zone & 2017 & No Action & MESC/MNA/IC \\
\hline 216-T-20 & T Farm Zone & 2031 & ABAR2W13 & ET Cap \\
\hline 216-T-21 & T Farm Zone & 2031 & ABAR2W05 & ET Cap \\
\hline 216-T-22 & T Farm Zone & 2031 & ABAR2W05 & ET Cap \\
\hline 216-T-23 & T Farm Zone & 2031 & ABAR2W05 & ET Cap \\
\hline $216-T-24$ & T Farm Zone & 2031 & ABAR2W05 & ET Cap \\
\hline 216-T-25 & T Farm Zone & 2031 & ABAR2W05 & ET Cap \\
\hline $216-T-26$ & T Farm Zone & 2031 & ABAR2W04 & ET Cap \\
\hline $216-\mathrm{T}-27$ & T Farm Zone & 2031 & ABAR2W04 & ET Cap \\
\hline 216-T-28 & T Farm Zone & 2031 & ABAR2W04 & ET Cap \\
\hline 216-T-29 & T Plant Zone & 2033 & ABAR w/ T Plant & ET Cap \\
\hline 216-T-3 & T Plant Zone & 2017 & No Action & MESC/MNA/IC \\
\hline 216-T-31 & T Farm Zone & 2031 & RTD/ABAR w/ TX-TY WMA & ET Cap \\
\hline $216-T-32$ & T Farm Zone & 2031 & ABAR2W03/T WMA & ET Cap \\
\hline $216-\mathrm{T}-33$ & T Plant Zone & 2017 & IBAR & ET Cap \\
\hline 216-T-34 & T Plant Zone & 2017 & IBAR & ET Cap \\
\hline $216-T-35$ & T Plant Zone & 2017 & IBAR & ET Cap \\
\hline $216-T-36$ & T Farm Zone & 2031 & RTD & 1 \\
\hline 216-T-4-1D & T Farm Zone & 2031 & RTD & 1 \\
\hline 216-T-4-2 & WM Zone & 2023 & RTD & 1 \\
\hline $216-\mathrm{T}-4 \mathrm{~A}$ & WM Zone & 2023 & IBAR & ET Cap \\
\hline 216-T-4B & WM Zone & 2023 & IBAR & ET Cap \\
\hline $216-T-5$ & T Farm Zone & 2031 & ABAR2W03/T WMA & ET Cap \\
\hline $216-T-6$ & T Plant Zone & 2017 & IBAR & ET Cap \\
\hline 216-T-7 & T Farm Zone & 2031 & ABAR2W03/T WMA & ET Cap \\
\hline 216-T-8 & T Plant Zone & 2017 & IBAR & ET Cap \\
\hline 216-Т-9 & T Plant Zone & 2017 & ABAR2W08 & ET Cap \\
\hline 216-TY-201 & T Farm Zone & 2031 & ABAR2W04 & ET Cap \\
\hline $216-U-1 \% 2$ & U Plant Zone & 2016 & IBAR & ET Cap \\
\hline 216-U-10 & 200-W Ponds Zone & 2016 & ABAR2W09 & ET Cap \\
\hline $216-U-11$ & 200-W Ponds Zone & 2016 & IBAR & ET Cap \\
\hline $216-U-12$ & U Plant Zone & 2016 & IBAR & ET Cap \\
\hline $216-U-13$ & S/U Farm Zone & 2028 & ABAR w/ U WMA & ET Cap \\
\hline $216-U-14$ & T Plant Zone & 2017 & No Action & MESC/MNA/IC \\
\hline 216-U-15 & U Plant Zone & 2016 & RTD & 1 \\
\hline 216-U-16 & U Plant Zone & 2016 & No Action & MESC/MNA/IC \\
\hline 216-U-17 & U Plant Zone & 2016 & No Action & MESC/MNA/IC \\
\hline $216-U-3$ & S/U Farm Zone & 2028 & IBAR & ET Cap \\
\hline $216-U-4$ & U Plant Zone & 2016 & RTD/ABAR w/ U Plant & ET Cap \\
\hline $216-U-4 A$ & U Plant Zone & 2016 & RTD/ABAR w/ U Plant & ET Cap \\
\hline $216-U-4 B$ & U Plant Zone & 2016 & RTD/ABAR w/ U Plant & ET Cap \\
\hline $216-U-5$ & U Plant Zone & 2016 & RTD & 1 \\
\hline $216-U-6$ & U Plant Zone & 2016 & RTD & 1 \\
\hline $216-U-7$ & U Plant Zone & 2016 & RTD/ABAR w/ U Plant & ET Cap \\
\hline $216-U-8$ & U Plant Zone & 2016 & IBAR & ET Cap \\
\hline $216-U-9$ & 200-W Ponds Zone & 2016 & No Action & MESC/MNA/IC \\
\hline 216-W-LWC & T Plant Zone & 2017 & IBAR & ET Cap \\
\hline $216-Z-1 \% 2$ & PFP Zone & 2017 & ABAR2W07/PFP & ET Cap \\
\hline 216-Z-10 & PFP Zone & 2017 & ABAR2W12/231-Z & ET Cap \\
\hline 216-Z-11 & PFP Zone & 2017 & ABAR2W10 & ET Cap \\
\hline $216-Z-12$ & PFP Zone & 2017 & ABAR2W07/PFP & ET Cap \\
\hline $216-Z-13$ & PFP Zone & 2017 & No Action & \\
\hline $216-Z-14$ & PFP Zone & 2017 & ABAR2W07/PFP & ET Cap \\
\hline 216-Z-15 & PFP Zone & 2017 & ABAR2W07/PFP & ET Cap \\
\hline $216-Z-16$ & PFP Zone & 2017 & IBAR & ET Cap \\
\hline 216-Z-17 & PFP Zone & 2017 & ABAR2W12/231-Z & ET Cap \\
\hline 216-Z-18 & PFP Zone & 2017 & ABAR2W07/PFP & ET Cap \\
\hline 216-Z-19 & PFP Zone & 2017 & ABAR2W10 & ET Cap \\
\hline $216-Z-1 A$ & PFP Zone & 2017 & ABAR2W07/PFP & ET Cap \\
\hline 216-Z-1D & PFP Zone & 2017 & ABAR2W10 & ET Cap \\
\hline $216-Z-20$ & PFP Zone & 2017 & ABAR2W10 & ET Cap \\
\hline
\end{tabular}




\begin{tabular}{|c|c|c|c|c|}
\hline WIDS Site Code & Zone & $\begin{array}{c}\text { mpleti } \\
\text { Date }\end{array}$ & Remedy & Notes \\
\hline $216-Z-21$ & PFP Zone & 2017 & IBAR & ET Cap \\
\hline $216-Z-3$ & PFP Zone & 2017 & ABAR2W07/PFP & ET Cap \\
\hline $216-Z-4$ & PFP Zone & 2017 & ABAR2W12/231-Z & ET Cap \\
\hline $216-Z-5$ & PFP Zone & 2017 & ABAR2W12/231-Z & ET Cap \\
\hline $216-Z-6$ & PFP Zone & 2017 & ABAR2W12/231-Z & ET Cap \\
\hline 216-Z-7 & PFP Zone & 2017 & ABAR2W12/231-Z & ET Cap \\
\hline $216-Z-8$ & PFP Zone & 2017 & ABAR2W07/PFP & ET Cap \\
\hline $216-Z-9$ & PFP Zone & 2017 & ABAR2W07/PFP & ET Cap \\
\hline $218-C-9$ & Semi-Works Zone & 2017 & RTD/IBAR & ET Cap \\
\hline 218-E-1 & Purex Zone & 2021 & IBAR & ET Cap \\
\hline 218-E-10 & Solid Waste Zone & 2027 & IBAR & ET Cap \\
\hline 218-E-12A & Solid Waste Zone & 2027 & IBAR & ET Cap \\
\hline 218-E-12B & Solid Waste Zone & 2027 & ABAR2E12 & ET Cap \\
\hline 218-E-2 & Solid Waste Zone & 2027 & ABAR2E14 & ET Cap \\
\hline $218-E-2 A$ & Solid Waste Zone & 2027 & ABAR2E14 & ET Cap \\
\hline $218-E-4$ & Solid Waste Zone & 2027 & IBAR & ET Cap \\
\hline 218-E-5 & Solid Waste Zone & 2027 & ABAR2E14 & ET Cap \\
\hline 218-E-5A & Solid Waste Zone & 2027 & ABAR2E14 & ET Cap \\
\hline 218-E-7 & B Plant Zone & 2022 & RTD & 1 \\
\hline 218-E-8 & Solid Waste Zone & 2027 & ABAR2E12 & ET Cap \\
\hline 218-E-9 & Solid Waste Zone & 2027 & ABAR2E14 & ET Cap \\
\hline 218-W-1 & WM Zone & 2023 & ABAR2W06 & ET Cap \\
\hline 218-W-11 & WM Zone & 2023 & IBAR & ET Cap \\
\hline $218-W-1 A$ & WM Zone & 2023 & IBAR & ET Cap \\
\hline $218-W-2$ & WM Zone & 2023 & ABAR2W06 & ET Cap \\
\hline $218-W-2 A$ & WM Zone & 2023 & ABAR2W01 & ET Cap \\
\hline $218-W-3$ & WM Zone & 2023 & ABAR2W01 & ET Cap \\
\hline 218-W-3A & WM Zone & 2023 & ABAR2W01 & ET Cap \\
\hline 218-W-3AE & WM Zone & 2023 & IBAR & ET Cap \\
\hline $218-W-4 A$ & WM Zone & 2023 & IBAR & ET Cap \\
\hline $218-W-4 B$ & WM Zone & 2023 & ABAR2W06 & ET Cap \\
\hline $218-W-4 C$ & WM Zone & 2023 & IBAR & ET Cap \\
\hline $218-W-5$ & WM Zone & 2023 & IBAR & ET Cap \\
\hline 221-B-WS-2 & B Plant Zone & 2022 & IBAR & Closed out as part of completion of 221B \\
\hline 241-A-101 & WTP/A Farm Zone & 2034 & ABAR w/ A-AN-AX-AY-AZ WMA & ET Cap \\
\hline 241-A-102 & WTPIA Farm Zone & 2034 & ABAR w/ A-AN-AX-AY-AZ WMA & ET Cap \\
\hline 241-A-103 & WTP/A Farm Zone & 2034 & ABAR w/ A-AN-AX-AY-AZ WMA & ET Cap \\
\hline 241-A-104 & WTPIA Farm Zone & 2034 & ABAR w/ A-AN-AX-AY-AZ WMA & ET Cap \\
\hline 241-A-105 & WTPIA Farm Zone & 2034 & ABAR w/ A-AN-AX-AY-AZ WMA & ET Cap \\
\hline 241-A-106 & WTP/A Farm Zone & 2034 & ABAR w/ A-AN-AX-AY-AZ WMA & ET Cap \\
\hline 241-AN-101 & WTPIA Farm Zone & 2034 & ABAR w/ A-AN-AX-AY-AZ WMA & ET Cap \\
\hline 241-AN-102 & WTPIA Farm Zone & 2034 & ABAR w/ A-AN-AX-AY-AZ WMA & ET Cap \\
\hline 241-AN-103 & WTP/A Farm Zone & 2034 & ABAR w/ A-AN-AX-AY-AZ WMA & ET Cap \\
\hline 241-AN-104 & WTPIA Farm Zone & 2034 & ABAR w/ A-AN-AX-AY-AZ WMA & ET Cap \\
\hline 241-AN-105 & WTPIA Farm Zone & 2034 & ABAR w/ A-AN-AX-AY-AZ WMA & ET Cap \\
\hline 241-AN-106 & WTPIA Farm Zone & 2034 & ABAR w/ A-AN-AX-AY-AZ WMA & ET Cap \\
\hline 241-AN-107 & WTP/A Farm Zone & 2034 & ABAR w/ A-AN-AX-AY-AZ WMA & ET Cap \\
\hline 241-AP-101 & WTPIA Farm Zone & 2034 & ABAR w/ AP WMA & ET Cap \\
\hline 241-AP-102 & WTP/A Farm Zone & 2034 & ABAR w/ AP WMA & ET Cap \\
\hline 241-AP-103 & WTP/A Farm Zone & 2034 & ABAR w/ AP WMA & ET Cap \\
\hline 241-AP-104 & WTPIA Farm Zone & 2034 & ABAR w/ AP WMA & ET Cap \\
\hline 241-AP-105 & WTP/A Farm Zone & 2034 & ABAR w/ AP WMA & ET Cap \\
\hline 241-AP-106 & WTPIA Farm Zone & 2034 & ABAR w/ AP WMA & ET Cap \\
\hline 241-AP-107 & WTPIA Farm Zone & 2034 & ABAR w/ AP WMA & ET Cap \\
\hline 241-AP-108 & WTP/A Farm Zone & 2034 & ABAR w/ AP WMA & ET Cap \\
\hline 241-AW-101 & WTP/A Farm Zone & 2034 & ABAR W/ AW WMA & ET Cap \\
\hline 241-AW-102 & WTPIA Farm Zone & 2034 & ABAR w/ AW WMA & ET Cap \\
\hline 241-AW-103 & WTPIA Farm Zone & 2034 & ABAR w/ AW WMA & ET Cap \\
\hline 241-AW-104 & WTPIA Farm Zone & 2034 & ABAR w/ AW WMA & ET Cap \\
\hline 241-AW-105 & WTPIA Farm Zone & 2034 & ABAR w/ AW WMA & ET Cap \\
\hline 241-AW-106 & WTPIA Farm Zone & 2034 & ABAR w/ AW WMA & ET Cap \\
\hline 241-AX-101 & WTP/A Farm Zone & 2034 & ABAR w/ A-AN-AX-AY-AZ WMA & ET Cap \\
\hline 241-AX-102 & WTP/A Farm Zone & 2034 & ABAR w/ A-AN-AX-AY-AZ WMA & ET Cap \\
\hline $241-A X-103$ & WTP/A Farm Zone & 2034 & ABAR w/ A-AN-AX-AY-AZ WMA & ET Cap \\
\hline 241-AX-104 & WTPIA Farm Zone & 2034 & ABAR w/ A-AN-AX-AY-AZ WMA & ET Cap \\
\hline 241-AY-101 & WTPIA Farm Zone & 2034 & ABAR w/ A-AN-AX-AY-AZ WMA & ET Cap \\
\hline
\end{tabular}




\begin{tabular}{|c|c|c|c|c|}
\hline \multicolumn{5}{|c|}{ Completion } \\
\hline WIDS Site Code & Zone & Date & Remedy & Notes \\
\hline 241-AY-102 & WTP/A Farm Zone & 2034 & ABAR W/ A-AN-AX-AY-AZ WMA & ET Cap \\
\hline 241-AZ-101 & WTPIA Farm Zone & 2034 & ABAR W/ A-AN-AX-AY-AZ WMA & ET Cap \\
\hline 241-AZ-102 & WTP/A Farm Zone & 2034 & ABAR W/ A-AN-AX-AY-AZ WMA & ET Cap \\
\hline 241-B-101 & B Farm Zone & 2030 & ABAR w/ B-BX-BY WMA & ET Cap \\
\hline 241-B-102 & B Farm Zone & 2030 & ABAR w/ B-BX-BY WMA & ET Cap \\
\hline 241-B-103 & B Farm Zone & 2030 & ABAR w/ B-BX-BY WMA & ET Cap \\
\hline 241-B-104 & B Farm Zone & 2030 & ABAR w/ B-BX-BY WMA & ET Cap \\
\hline 241-B-105 & B Farm Zone & 2030 & ABAR w/ B-BX-BY WMA & ET Cap \\
\hline 241-B-106 & B Farm Zone & 2030 & ABAR w/ B-BX-BY WMA & ET Cap \\
\hline 241-B-107 & B Farm Zone & 2030 & ABAR w/ B-BX-BY WMA & ET Cap \\
\hline 241-B-108 & B Farm Zone & 2030 & ABAR w/ B-BX-BY WMA & ET Cap \\
\hline 241-B-109 & B Farm Zone & 2030 & ABAR w/ B-BX-BY WMA & ET Cap \\
\hline 241-B-110 & B Farm Zone & 2030 & ABAR w/ B-BX-BY WMA & ET Cap \\
\hline 241-B-111 & B Farm Zone & 2030 & ABAR W/ B-BX-BY WMA & ET Cap \\
\hline 241-B-112 & B Farm Zone & 2030 & ABAR w/ B-BX-BY WMA & ET Cap \\
\hline 241-B-201 & B Farm Zone & 2030 & ABAR w/ B-BX-BY WMA & ET Cap \\
\hline 241-B-202 & B Farm Zone & 2030 & ABAR w/ B-BX-BY WMA & ET Cap \\
\hline 241-B-203 & B Farm Zone & 2030 & ABAR w/ B-BX-BY WMA & ET Cap \\
\hline 241-B-204 & B Farm Zone & 2030 & ABAR w/ B-BX-BY WMA & ET Cap \\
\hline 241-B-361 & B Plant Zone & 2022 & IBAR & \\
\hline 241-BX-101 & B Farm Zone & 2030 & ABAR w/ B-BX-BY WMA & ET Cap \\
\hline 241-BX-102 & B Farm Zone & 2030 & ABAR w/ B-BX-BY WMA & ET Cap \\
\hline 241-BX-103 & B Farm Zone & 2030 & ABAR w/ B-BX-BY WMA & ET Cap \\
\hline 241-BX-104 & B Farm Zone & 2030 & ABAR w/ B-BX-BY WMA & ET Cap \\
\hline 241-BX-105 & B Farm Zone & 2030 & ABAR w/ B-BX-BY WMA & ET Cap \\
\hline 241-BX-106 & B Farm Zone & 2030 & ABAR w/ B-BX-BY WMA & ET Cap \\
\hline 241-BX-107 & B Farm Zone & 2030 & ABAR w/ B-BX-BY WMA & ET Cap \\
\hline 241-BX-108 & B Farm Zone & 2030 & ABAR w/ B-BX-BY WMA & ET Cap \\
\hline 241-BX-109 & B Farm Zone & 2030 & ABAR w/ B-BX-BY WMA & ET Cap \\
\hline 241-BX-110 & B Farm Zone & 2030 & ABAR w/ B-BX-BY WMA & ET Cap \\
\hline 241-BX-111 & B Farm Zone & 2030 & ABAR w/ B-BX-BY WMA & ET Cap \\
\hline 241-BX-112 & B Farm Zone & 2030 & ABAR w/ B-BX-BY WMA & ET Cap \\
\hline 241-BY-101 & B Farm Zone & 2030 & ABAR w/ B-BX-BY WMA & ET Cap \\
\hline 241-BY-102 & B Farm Zone & 2030 & ABAR w/ B-BX-BY WMA & ET Cap \\
\hline 241-BY-103 & B Farm Zone & 2030 & ABAR w/ B-BX-BY WMA & ET Cap \\
\hline 241-BY-104 & B Farm Zone & 2030 & ABAR w/ B-BX-BY WMA & ET Cap \\
\hline 241-BY-105 & B Farm Zone & 2030 & ABAR w/ B-BX-BY WMA & ET Cap \\
\hline 241-BY-106 & B Farm Zone & 2030 & ABAR w/ B-BX-BY WMA & ET Cap \\
\hline 241-BY-107 & B Farm Zone & 2030 & ABAR w/ B-BX-BY WMA & ET Cap \\
\hline 241-BY-108 & B Farm Zone & 2030 & ABAR w/ B-BX-BY WMA & ET Cap \\
\hline 241-BY-109 & B Farm Zone & 2030 & ABAR w/ B-BX-BY WMA & ET Cap \\
\hline 241-BY-110 & B Farm Zone & 2030 & ABAR w/ B-BX-BY WMA & ET Cap \\
\hline 241-BY-111 & B Farm Zone & 2030 & ABAR w/ B-BX-BY WMA & ET Cap \\
\hline 241-BY-112 & B Farm Zone & 2030 & ABAR w/ B-BX-BY WMA & ET Cap \\
\hline 241-C-101 & C Farm Zone & 2030 & ABAR W/ C WMA & ET Cap \\
\hline 241-C-102 & C Farm Zone & 2030 & ABAR W/ C WMA & ET Cap \\
\hline 241-C-103 & C Farm Zone & 2030 & ABAR W/ C WMA & ET Cap \\
\hline 241-C-104 & C Farm Zone & 2030 & ABAR W/ C WMA & ET Cap \\
\hline 241-C-105 & C Farm Zone & 2030 & ABAR W/ C WMA & ET Cap \\
\hline 241-C-106 & C Farm Zone & 2030 & ABAR w/ C WMA & ET Cap \\
\hline 241-C-107 & C Farm Zone & 2030 & ABAR W/ C WMA & ET Сар \\
\hline 241-C-108 & C Farm Zone & 2030 & ABAR W/ C WMA & ET Cap \\
\hline 241-C-109 & C Farm Zone & 2030 & ABAR W/ C WMA & ET Cap \\
\hline 241-C-110 & C Farm Zone & 2030 & ABAR W/ C WMA & ET Cap \\
\hline 241-C-111 & C Farm Zone & 2030 & ABAR W/ C WMA & ET Cap \\
\hline 241-C-112 & C Farm Zone & 2030 & ABAR w/ C WMA & ET Cap \\
\hline 241-C-201 & C Farm Zone & 2030 & ABAR W/ C WMA & ET Cap \\
\hline 241-C-202 & C Farm Zone & 2030 & ABAR W/ C WMA & ET Cap \\
\hline 241-C-203 & C Farm Zone & 2030 & ABAR W/ C WMA & ET Cap \\
\hline 241-C-204 & C Farm Zone & 2030 & ABAR w/ C WMA & ET Cap \\
\hline 241-S-101 & S/U Farm Zone & 2030 & ABAR w/ S-SX-SY WMA & ET Cap \\
\hline 241-S-102 & S/U Farm Zone & 2030 & ABAR w/ S-SX-SY WMA & ET Cap \\
\hline 241-S-103 & S/U Farm Zone & 2030 & ABAR W/ S-SX-SY WMA & ET Cap \\
\hline 241-S-104 & S/U Farm Zone & 2030 & ABAR w/ S-SX-SY WMA & ET Cap \\
\hline 241-S-105 & S/U Farm Zone & 2030 & ABAR W/ S-SX-SY WMA & ET Cap \\
\hline 241-S-106 & S/U Farm Zone & 2030 & ABAR w/ S-SX-SY WMA & ET Cap \\
\hline
\end{tabular}




\begin{tabular}{|c|c|c|c|c|}
\hline \multicolumn{5}{|c|}{ Completion } \\
\hline WIDS Site Code & Zone & Date & Remedy & Notes \\
\hline 241-S-107 & S/U Farm Zone & 2030 & ABAR w/ S-SX-SY WMA & ET Cap \\
\hline 241-S-108 & S/U Farm Zone & 2030 & ABAR w/ S-SX-SY WMA & ET Cap \\
\hline 241-S-109 & S/U Farm Zone & 2030 & ABAR w/ S-SX-SY WMA & ET Cap \\
\hline 241-S-110 & S/U Farm Zone & 2030 & ABAR w/ S-SX-SY WMA & ET Cap \\
\hline 241-S-111 & S/U Farm Zone & 2030 & ABAR w/ S-SX-SY WMA & ET Cap \\
\hline 241-S-112 & S/U Farm Zone & 2030 & ABAR w/ S-SX-SY WMA & ET Cap \\
\hline 241-SX-101 & S/U Farm Zone & 2030 & ABAR w/ S-SX-SY WMA & ET Cap \\
\hline 241-SX-102 & S/U Farm Zone & 2030 & ABAR w/ S-SX-SY WMA & ET Cap \\
\hline 241-SX-103 & S/U Farm Zone & 2030 & ABAR w/ S-SX-SY WMA & ET Cap \\
\hline 241-SX-104 & S/U Farm Zone & 2030 & ABAR w/ S-SX-SY WMA & ET Cap \\
\hline 241-SX-105 & S/U Farm Zone & 2030 & ABAR w/ S-SX-SY WMA & ET Cap \\
\hline 241-SX-106 & S/U Farm Zone & 2030 & ABAR w/ S-SX-SY WMA & ET Cap \\
\hline 241-SX-107 & S/U Farm Zone & 2030 & ABAR w/ S-SX-SY WMA & ET Cap \\
\hline 241-SX-108 & S/U Farm Zone & 2030 & ABAR w/ S-SX-SY WMA & ET Cap \\
\hline 241-SX-109 & S/U Farm Zone & 2030 & ABAR w/ S-SX-SY WMA & ET Cap \\
\hline 241-SX-110 & S/U Farm Zone & 2030 & ABAR w/ S-SX-SY WMA & ET Cap \\
\hline 241-SX-111 & S/U Farm Zone & 2030 & ABAR w/ S-SX-SY WMA & ET Cap \\
\hline 241-SX-112 & S/U Farm Zone & 2030 & ABAR w/ S-SX-SY WMA & ET Cap \\
\hline 241-SX-113 & S/U Farm Zone & 2030 & ABAR w/ S-SX-SY WMA & ET Cap \\
\hline $241-S X-114$ & S/U Farm Zone & 2030 & ABAR w/ S-SX-SY WMA & ET Cap \\
\hline 241-SX-115 & S/U Farm Zone & 2030 & ABAR w/ S-SX-SY WMA & ET Cap \\
\hline 241-SY-101 & S/U Farm Zone & 2030 & ABAR w/ S-SX-SY WMA & ET Cap \\
\hline 241-SY-102 & S/U Farm Zone & 2030 & ABAR w/ S-SX-SY WMA & ET Cap \\
\hline 241-SY-103 & S/U Farm Zone & 2030 & ABAR w/ S-SX-SY WMA & ET Cap \\
\hline 241-T-101 & T Farm Zone & 2031 & ABAR2W03/T WMA & ET Cap \\
\hline 241-T-102 & T Farm Zone & 2031 & ABAR2W03/T WMA & ET Cap \\
\hline 241-T-103 & T Farm Zone & 2031 & ABAR2W03/T WMA & ET Cap \\
\hline 241-T-104 & T Farm Zone & 2031 & ABAR2W03/T WMA & ET Cap \\
\hline 241-T-105 & T Farm Zone & 2031 & ABAR2W03/T WMA & ET Cap \\
\hline 241-T-106 & T Farm Zone & 2031 & ABAR2W03/T WMA & ET Cap \\
\hline 241-T-107 & T Farm Zone & 2031 & ABAR2W03/T WMA & ET Cap \\
\hline 241-T-108 & T Farm Zone & 2031 & ABAR2W03/T WMA & ET Cap \\
\hline 241-T-109 & T Farm Zone & 2031 & ABAR2W03/T WMA & ET Cap \\
\hline 241-T-110 & T Farm Zone & 2031 & ABAR2W03/T WMA & ET Cap \\
\hline 241-T-111 & T Farm Zone & 2031 & ABAR2W03/T WMA & ET Cap \\
\hline 241-T-112 & T Farm Zone & 2031 & ABAR2W03/T WMA & ET Cap \\
\hline 241-T-201 & T Farm Zone & 2031 & ABAR2W03/T WMA & ET Cap \\
\hline 241-T-202 & T Farm Zone & 2031 & ABAR2W03/T WMA & ET Cap \\
\hline 241-T-203 & T Farm Zone & 2031 & ABAR2W03/T WMA & ET Cap \\
\hline 241-T-204 & T Farm Zone & 2031 & ABAR2W03/T WMA & ET Cap \\
\hline 241-T-361 & T Plant Zone & 2017 & IBAR & \\
\hline 241-TX-101 & T Farm Zone & 2031 & ABAR w/ TX-TY WMA & ET Cap \\
\hline 241-TX-102 & T Farm Zone & 2031 & ABAR W/ TX-TY WMA & ET Cap \\
\hline 241-TX-103 & T Farm Zone & 2031 & ABAR W/ TX-TY WMA & ET Cap \\
\hline 241-TX-104 & T Farm Zone & 2031 & ABAR W/ TX-TY WMA & ET Cap \\
\hline 241-TX-105 & T Farm Zone & 2031 & ABAR W/ TX-TY WMA & ET Cap \\
\hline 241-TX-106 & T Farm Zone & 2031 & ABAR W/ TX-TY WMA & ET Cap \\
\hline 241-TX-107 & T Farm Zone & 2031 & ABAR W/ TX-TY WMA & ET Cap \\
\hline 241-TX-108 & T Farm Zone & 2031 & ABAR W/ TX-TY WMA & ET Cap \\
\hline 241-TX-109 & T Farm Zone & 2031 & ABAR W/ TX-TY WMA & ET Cap \\
\hline 241-TX-110 & T Farm Zone & 2031 & ABAR W/ TX-TY WMA & ET Cap \\
\hline 241-TX-111 & T Farm Zone & 2031 & ABAR W/ TX-TY WMA & ET Cap \\
\hline 241-TX-112 & T Farm Zone & 2031 & ABAR W/ TX-TY WMA & ET Cap \\
\hline 241-TX-113 & T Farm Zone & 2031 & ABAR w/ TX-TY WMA & ET Cap \\
\hline 241-TX-114 & T Farm Zone & 2031 & ABAR W/ TX-TY WMA & ET Cap \\
\hline 241-TX-115 & T Farm Zone & 2031 & ABAR W/ TX-TY WMA & ET Cap \\
\hline 241-TX-116 & T Farm Zone & 2031 & ABAR W/ TX-TY WMA & ET Cap \\
\hline 241-TX-117 & T Farm Zone & 2031 & ABAR W/ TX-TY WMA & ET Cap \\
\hline 241-TX-118 & T Farm Zone & 2031 & ABAR W/ TX-TY WMA & ET Cap \\
\hline 241-TY-101 & T Farm Zone & 2031 & ABAR W/ TX-TY WMA & ET Cap \\
\hline 241-TY-102 & T Farm Zone & 2031 & ABAR W/ TX-TY WMA & ET Cap \\
\hline 241-TY-103 & T Farm Zone & 2031 & ABAR W/ TX-TY WMA & ET Cap \\
\hline 241-TY-104 & T Farm Zone & 2031 & ABAR W/ TX-TY WMA & ET Cap \\
\hline 241-TY-105 & T Farm Zone & 2031 & ABAR W/ TX-TY WMA & ET Cap \\
\hline 241-TY-106 & T Farm Zone & 2031 & ABAR W/ TX-TY WMA & ET Cap \\
\hline 241-U-101 & S/U Farm Zone & 2030 & ABAR w/ U WMA & ET Cap \\
\hline
\end{tabular}




\begin{tabular}{|c|c|c|c|c|}
\hline WIDS Site Code & Zone & $\begin{array}{l}\text { mpleti } \\
\text { Date }\end{array}$ & Remedy & Notes \\
\hline 241-U-102 & S/U Farm Zone & 2030 & ABAR w/ U WMA & ET Cap \\
\hline 241-U-103 & S/U Farm Zone & 2030 & ABAR W/ U WMA & ET Cap \\
\hline 241-U-104 & S/U Farm Zone & 2030 & ABAR W/ U WMA & ET Cap \\
\hline 241-U-105 & S/U Farm Zone & 2030 & ABAR W/ U WMA & ET Cap \\
\hline 241-U-106 & S/U Farm Zone & 2030 & ABAR W/ U WMA & ET Cap \\
\hline 241-U-107 & S/U Farm Zone & 2030 & ABAR W/ U WMA & ET Cap \\
\hline $241-U-108$ & S/U Farm Zone & 2030 & ABAR W/ U WMA & ET Cap \\
\hline 241-U-109 & S/U Farm Zone & 2030 & ABAR W/ U WMA & ET Cap \\
\hline 241-U-110 & S/U Farm Zone & 2030 & ABAR W/ U WMA & ET Cap \\
\hline 241-U-111 & S/U Farm Zone & 2030 & ABAR w/ U WMA & ET Cap \\
\hline 241-U-112 & S/U Farm Zone & 2030 & ABAR w/ U WMA & ET Cap \\
\hline 241-U-201 & S/U Farm Zone & 2030 & ABAR W/ U WMA & ET Cap \\
\hline 241-U-202 & S/U Farm Zone & 2030 & ABAR W/ U WMA & ET Cap \\
\hline $241-U-203$ & S/U Farm Zone & 2030 & ABAR W/ U WMA & ET Cap \\
\hline 241-U-204 & S/U Farm Zone & 2030 & ABAR W/ U WMA & ET Cap \\
\hline 241-U-361 & U Plant Zone & 2016 & RTD/IBAR & ET Cap \\
\hline 241-WR-VAULT & U Plant Zone & 2016 & RTD/ABAR w/ U Plant & ET Cap \\
\hline 241-Z-361 & PFP Zone & 2017 & RTD/ABAR2W07/PFP & ET Cap \\
\hline 241-Z-8 & PFP Zone & 2017 & RTD/ABAR2W07/PFP & ET Cap \\
\hline 2607-E1 & 200-E Admin Zone & 2024 & No Action & \\
\hline 2607-E10 & WTPIA Farm Zone & 2034 & No Action & \\
\hline 2607-E11 & 200-E Admin Zone & 2024 & No Action & \\
\hline 2607-E12 & 200-E Ponds Zone & 2016 & No Action & \\
\hline 2607-E1A & 200-E Admin Zone & 2024 & No Action & \\
\hline 2607-E3 & B Plant Zone & 2022 & RTD & 1 \\
\hline 2607-E4 & B Plant Zone & 2022 & ABAR w/ B Plant & ET Cap \\
\hline 2607-E5 & Semi-Works Zone & 2017 & No Action & \\
\hline 2607-E6 & 200-E Admin Zone & 2024 & No Action & \\
\hline 2607-E7A & Semi-Works Zone & 2017 & No Action & \\
\hline 2607-E8 & 200-E Admin Zone & 2024 & No Action & \\
\hline 2607-E8A & 200-E Admin Zone & 2024 & No Action & \\
\hline 2607-E9 & B Farm Zone & 2026 & RTD & 1 \\
\hline 2607-EA & Purex Zone & 2021 & No Action & \\
\hline 2607-EB & B Farm Zone & 2026 & ABAR w/ B-BX-BY WMA & ET Cap \\
\hline 2607-EC & WTPIA Farm Zone & 2034 & No Action & \\
\hline 2607-ED & WTPIA Farm Zone & 2034 & ABAR W/ A-AN-AX-AY-AZ WMA & ET Cap \\
\hline 2607-EG & C Farm Zone & 2016 & RTD/ABAR w/ C WMA & ET Cap \\
\hline 2607-EL & 200-E Admin Zone & 2024 & No Action & \\
\hline 2607-EM & 200-E Admin Zone & 2024 & No Action & \\
\hline 2607-EP & 200-E Admin Zone & 2024 & No Action & \\
\hline 2607-EQ & 200-E Admin Zone & 2024 & No Action & \\
\hline 2607-FSN & ERDF Zone & 2029 & No Action & \\
\hline 2607-W1 & T Plant Zone & 2017 & No Action & \\
\hline 2607-W2 & T Plant Zone & 2017 & No Action & \\
\hline 2607-W3 & T Plant Zone & 2017 & RTD & 1 \\
\hline 2607-W4 & T Plant Zone & 2017 & RTD & 1 \\
\hline 2607-W5 & U Plant Zone & 2016 & No Action & MESC/MNA/IC \\
\hline 2607-W6 & 200-W Ponds Zone & 2016 & No Action & \\
\hline 2607-W7 & U Plant Zone & 2016 & No Action & \\
\hline 2607-W8 & PFP Zone & 2017 & ABAR2W07/PFP & ET Cap \\
\hline 2607-W9 & S/U Farm Zone & 2028 & No Action & \\
\hline 2607-WA & PFP Zone & 2017 & No Action & \\
\hline 2607-WC & 200-W Ponds Zone & 2016 & No Action & \\
\hline 2607-WL & WM Zone & 2023 & No Action & \\
\hline $2607-Z$ & PFP Zone & 2017 & ABAR2W07/PFP & ET Cap \\
\hline $2607-Z 1$ & PFP Zone & 2017 & ABAR2W07/PFP & ET Cap \\
\hline 2704-C-WS-1 & Semi-Works Zone & 2017 & RTD & 1 \\
\hline $296-A-13$ & Purex Zone & 2021 & D\&D / ET Cap & Close out as part of 291AR \\
\hline $296-S-13$ & REDOX Zone & 2030 & RTD / ET Cap & Closed out as part of completion of $222 \mathrm{~S}$ \\
\hline 296-S-16 & REDOX Zone & 2030 & RTD / ET Cap & Closed out as part of completion of 2195 \\
\hline 296-S-21 & REDOX Zone & 2030 & RTD / ET Cap & Closed out as part of completion of $222 \mathrm{~S}$ \\
\hline 299-E24-111 & Purex Zone & 2021 & ABAR2E07 & ET Cap \\
\hline 600-148_east & ERDF Zone & 2035 & IBAR & ET Cap \\
\hline 600-148_west & ERDF Zone & 2035 & IBAR & ET Cap \\
\hline $600-211$ & ETF Zone & 2033 & No Action & \\
\hline $600-214$ & ETF Zone & 2033 & No Action & \\
\hline
\end{tabular}




\begin{tabular}{|c|c|c|c|c|}
\hline WIDS Site Code & Zone & $\begin{array}{l}\text { Dmpleti } \\
\text { Date }\end{array}$ & Remedy & Notes \\
\hline $6607-16$ & ETF Zone & 2033 & No Action & \\
\hline $6607-5$ & ERDF Zone & 2029 & No Action & \\
\hline $6607-9$ & ERDF Zone & 2029 & No Action & \\
\hline B_PLANT_FILTER & B Plant Zone & 2022 & ABAR w/ B Plant & Closed out as part of completion of $221 B$ \\
\hline HWVPP - & CSB Zone & 2031 & No Action & \\
\hline UPR-200-E-1 & B Plant Zone & 2022 & ABAR w/ B Plant & ET Cap \\
\hline UPR-200-E-10 & Purex Zone & 2021 & RTD & \\
\hline UPR-200-E-112 & B Plant Zone & 2022 & RTD & 1 \\
\hline UPR-200-E-117 & Purex Zone & 2021 & ABAR2E10/PUREX & ABAR2E10/ET-Mono \\
\hline UPR-200-E-12 & Purex Zone & 2021 & RTD & \\
\hline UPR-200-E-140 & B Plant Zone & 2022 & ABAR w/ B Plant & ET Cap \\
\hline UPR-200-E-145 & 200-E Ponds Zone & 2016 & No Action & MESC/MNA/IC \\
\hline UPR-200-E-17 & Purex Zone & 2021 & No Action & \\
\hline UPR-200-E-29 & Purex Zone & 2021 & IBAR & ET Cap \\
\hline UPR-200-E-3 & B Plant Zone & 2022 & ABAR w/ B Plant & ET Cap \\
\hline UPR-200-E-33 & Purex Zone & 2021 & RTD & \\
\hline UPR-200-E-36 & Semi-Works Zone & 2017 & RTD & 1 \\
\hline UPR-200-E-39 & Purex Zone & 2021 & No Action & \\
\hline UPR-200-E-43 & B Farm Zone & 2026 & ABAR w/ B-BX-BY WMA & ET Cap \\
\hline UPR-200-E-44 & B Plant Zone & 2022 & ABAR w/ B Plant & ET Cap \\
\hline UPR-200-E-45 & B Plant Zone & 2022 & RTD/ABAR2E3 & ET Cap \\
\hline UPR-200-E-50 & WTP/A Farm Zone & 2034 & RTD & 1 \\
\hline UPR-200-E-52 & B Plant Zone & 2022 & ABAR w/ B Plant & ET Cap \\
\hline UPR-200-E-54 & B Plant Zone & 2022 & ABAR w/ B Plant & ET Cap \\
\hline UPR-200-E-55 & B Plant Zone & 2022 & ABAR w/ B Plant & ET Cap \\
\hline UPR-200-E-56 & 200-E Ponds Zone & 2016 & No Action & \\
\hline UPR-200-E-7 & B Plant Zone & 2022 & RTD & 1 \\
\hline UPR-200-E-77 & B Plant Zone & 2022 & IBAR & ET Cap \\
\hline UPR-200-E-78 & Solid Waste Zone & 2027 & IBAR & ET Cap \\
\hline UPR-200-E-79 & B Farm Zone & 2026 & No Action & MESC/MNA/IC \\
\hline UPR-200-E-80 & B Plant Zone & 2022 & ABAR w/ B Plant & ET Cap \\
\hline UPR-200-E-84 & B Plant Zone & 2022 & RTD/ABAR2E2 & ET Cap \\
\hline UPR-200-E-85 & B Plant Zone & 2022 & ABAR w/ B Plant & ET Cap \\
\hline UPR-200-E-86 & C Farm Zone & 2016 & IBAR & ET Cap \\
\hline UPR-200-E-87 & B Plant Zone & 2022 & ABAR w/ B Plant & ET Cap \\
\hline UPR-200-E-9 & B Farm Zone & 2026 & IBAR & ET Cap \\
\hline UPR-200-E-99 & C Farm Zone & 2016 & RTD & 1 \\
\hline UPR-200-W-101 & U Plant Zone & 2016 & ABAR w/ U Plant & ET Cap \\
\hline UPR-200-W-102 & T Plant Zone & 2033 & ABAR w/ T Plant & ET Cap \\
\hline UPR-200-W-103 & PFP Zone & 2017 & ABAR2W07/PFP & ET Cap \\
\hline UPR-200-W-108 & S/U Farm Zone & 2028 & RTD & 1 \\
\hline UPR-200-W-109 & REDOX Zone & 2030 & No Action & \\
\hline UPR-200-W-113 & T Farm Zone & 2031 & ABAR2W13 & ET Cap \\
\hline UPR-200-W-130 & PFP Zone & 2017 & ABAR2W12/231-Z & ET Cap \\
\hline UPR-200-W-131 & T Farm Zone & 2031 & ABAR2W13 & ET Cap \\
\hline UPR-200-W-135 & T Farm Zone & 2031 & ABAR2W13 & ET Cap \\
\hline UPR-200-W-138 & U Plant Zone & 2016 & ABAR w/ U Plant & ET Cap \\
\hline UPR-200-W-164 & S/U Farm Zone & 2028 & RTD & 1 \\
\hline UPR-200-W-19 & U Plant Zone & 2016 & No Action & MESC/MNA/IC \\
\hline UPR-200-W-2 & T Plant Zone & 2033 & ABAR w/ T Plant & ET Cap \\
\hline UPR-200-W-20 & S/U Farm Zone & 2028 & ABAR w/ S-SX-SY WMA & ET Cap \\
\hline UPR-200-W-21 & T Plant Zone & 2033 & ABAR w/ T Plant & ET Cap \\
\hline UPR-200-W-28 & T Farm Zone & 2031 & ABAR2W13 & ET Cap \\
\hline UPR-200-W-29 & T Farm Zone & 2031 & ABAR2W03/T WMA & ET Cap \\
\hline UPR-200-W-32 & REDOX Zone & 2030 & RTD & 1 \\
\hline UPR-200-W-33 & U Plant Zone & 2016 & RTD/ABAR w/ U Plant & ET Cap \\
\hline UPR-200-W-38 & T Plant Zone & 2033 & ABAR w/ T Plant & ET Cap \\
\hline UPR-200-W-39 & U Plant Zone & 2016 & ABAR w/ U Plant & ET Cap \\
\hline UPR-200-W-44 & T Plant Zone & 2017 & RTD & 1 \\
\hline UPR-200-W-55 & U Plant Zone & 2016 & ABAR w/ U Plant & ET Cap \\
\hline UPR-200-W-61 & REDOX Zone & 2030 & ABAR w/ REDOX & ET Cap \\
\hline UPR-200-W-68 & 200-W Ponds Zone & 2016 & No Action & \\
\hline UPR-200-W-69 & REDOX Zone & 2030 & RTD & 1 \\
\hline UPR-200-W-71 & S/U Farm Zone & 2028 & ABAR w/ U WMA & ET Cap \\
\hline UPR-200-W-78 & U Plant Zone & 2016 & ABAR w/ U Plant & ET Cap \\
\hline UPR-200-W-8 & U Plant Zone & 2016 & No Action & \\
\hline
\end{tabular}




\begin{tabular}{lllll}
\multicolumn{1}{c}{} & \multicolumn{1}{c}{$\begin{array}{c}\text { Completion } \\
\text { WIDS Site Code }\end{array}$} & \multicolumn{1}{c}{ Zone } & Remedy & Notes \\
UPR-200-W-82 & REDOX Zone & 2030 & No Action & MESC/MNA/IC \\
UPR-200-W-87 & REDOX Zone & 2030 & ABAR w/ REDOX & ET Cap \\
UPR-200-W-96 & REDOX Zone & 2030 & RTD & 1 \\
UPR-200-W-97 & T Farm Zone & 2031 & ABAR2W03/T WMA & ET Cap \\
UPR-200-W-98 & T Plant Zone & 2033 & ABAR w/ T Plant & ET Cap \\
UPR-600-12 & NRDWL/BC Control Zone & 2015 & No Action & MESC/MNA/IC
\end{tabular}

Above remedy assignments made based on review of "All_WIDS_Review_for_CPCP_update.xIs" provided via E-mail Hildebrand (Holten) to Kincaid July 8, 2005

Note: These sites are listed under the tab "In CP Closure"

\begin{tabular}{|c|c|c|c|c|}
\hline WIDS Site Code & Zone & $\begin{array}{l}\text { mplet } \\
\text { Date }\end{array}$ & Remedy & Notes \\
\hline 200_ETF & ETF & 2032 & $D \& D$ & \\
\hline $200-E-137$ & B plant & 2022 & RTD / ET Cap & \\
\hline 200-E-138 & B plant & 2022 & RTD / ET Cap & \\
\hline 200-E-17 & ETF & 2032 & $D \& D$ & \\
\hline $200-E-30$ & B plant & 2022 & D\&D / ET Cap & \\
\hline 200-E-54 & PUREX & 2021 & ET Cap & \\
\hline $200-W-40$ & T Plant & 2033 & D\&D / ET Cap & \\
\hline $200-W-43$ & REDOX & 2030 & D\&D / ET Cap & \\
\hline $200-W-44$ & U Plant & 2016 & D\&D / ET Cap & \\
\hline $200-W-45$ & T Plant & 2033 & D\&D / ET Cap & \\
\hline $200-W-72$ & PFP & 2017 & no action & \\
\hline 200-W-PP & T Plant & 2033 & IBAR & ET Cap \\
\hline $201-C$ & Semi-Works & 2017 & D\&D / ET Cap & \\
\hline $202-S$ & REDOX & 2030 & D\&D / ET Cap & \\
\hline $205-A$ & PUREX & 2021 & $\mathrm{D} \& \mathrm{D}$ & \\
\hline 2101-M-POND & 200-E Admin & 2024 & RTD & \\
\hline $212-\mathrm{N}$ & 200-E Ponds & 2016 & $D \& D$ & \\
\hline $212-P$ & 200-E Ponds & 2016 & $D \& D$ & \\
\hline 212-R & 200-E Ponds & 2016 & $D \& D$ & \\
\hline 218-E-14 & PUREX & 2021 & D\&D / ET Cap & \\
\hline 218-E-15 & PUREX & 2021 & D\&D / ET Cap & \\
\hline 218-E-LLW & IDF & 2035 & IBAR & ET Cap \\
\hline 218-E-RCRA & IDF & 2035 & IBAR & ET Cap \\
\hline $221-B$ & B plant & 2022 & IBAR & ET Cap \\
\hline 221-B_SDT & B plant & 2022 & IBAR & ET Cap \\
\hline $221-\mathrm{T}$ & $\mathrm{T}$ plant & 2033 & IBAR & ET Cap \\
\hline 221-T-11-R & T plant & 2033 & IBAR & ET Cap \\
\hline $221-U$ & U plant & 2016 & IBAR & ET Cap \\
\hline 222-SD & REDOX & 2030 & IBAR & ET Cap \\
\hline 224-B & B plant & 2022 & IBAR & ET Cap \\
\hline $224-\mathrm{T}$ & T plant & 2033 & IBAR & ET Cap \\
\hline $224-U$ & U plant & 2016 & IBAR & ET Cap \\
\hline $225-B$ & B plant & 2022 & IBAR & ET Cap \\
\hline $231-Z$ & PFP & 2017 & IBAR & ET Cap \\
\hline $232-Z$ & PFP & 2017 & D\&D / ET Cap & \\
\hline 233-S & REDOX & 2030 & D\&D / ET Cap & \\
\hline $234-5 Z$ & PFP & 2017 & IBAR & ET Cap \\
\hline 2607-EK & 200-E Admin & 2024 & no action & \\
\hline 2607-ER & 200-E Admin & 2024 & no action & \\
\hline 2607-FSM & 100 N Area & 2012 & RTD & \\
\hline 2607-WB & PFP & 2017 & no action & \\
\hline 2711-S & REDOX & 2030 & D\&D / ET Cap & \\
\hline $2718-S$ & REDOX & 2030 & D\&D / ET Cap & \\
\hline $276-S$ & REDOX & 2030 & D\&D / ET Cap & \\
\hline $276-U$ & U plant & 2016 & IBAR & ET Cap \\
\hline 2904-SA & REDOX & 2030 & $D \& D$ & \\
\hline 291-C & Semi-Works & 2017 & D\&D / ET Cap & \\
\hline 291-S-1 & REDOX & 2030 & RTD / ET Cap & \\
\hline 291-U & U plant & 2016 & D\&D / ET Cap & \\
\hline 291-U-1 & U plant & 2016 & RTD & \\
\hline 291-WTP & WTPIA farm & 2034 & RTD & \\
\hline $292-S$ & REDOX & 2030 & D\&D / ET Cap & \\
\hline
\end{tabular}




\begin{tabular}{|c|c|c|c|c|}
\hline WIDS Site Code & Zone & Date & Remedy & Notes \\
\hline 293-S & REDOX & 2030 & D\&D / ET Cap & \\
\hline 296-S-1 & REDOX & 2030 & RTD / ET Cap & \\
\hline 296-S-12 & REDOX & 2030 & RTD / ET Cap & \\
\hline 296-U-10 & U plant & 2016 & RTD / ET Cap & \\
\hline $600-117$ & Zone 25 - 300 Area & 2011 & RTD & \\
\hline $600-256$ & ERDF & 2029 & no action & \\
\hline $600-33$ & 100 B/C Area & 2006 & RTD & \\
\hline $600-58$ & Zone 23 - 100 Area & 2035 & RTD & \\
\hline $600-59$ & $\begin{array}{l}\text { Zone } 23 \text { - } 100 \text { Area } \\
\text { Zone } 24 \text { - } 600 \text { Area }\end{array}$ & 2035 & RTD & \\
\hline $6607-07$ & Essential & 2034 & no action & \\
\hline $6607-18$ & ERDF & 2029 & no action & \\
\hline GTF & WPT/A farm & 2034 & no action & \\
\hline GTFL & WPT/A farm & 2034 & no action & \\
\hline RMWSF & CWC & 2033 & RTD & \\
\hline TRUSAF & $\mathrm{T}$ plant & 2033 & $D \& D$ & \\
\hline UPR-200-E-105 & B farm & 2026 & ET Cap & \\
\hline UPR-200-E-106 & Solid Waste & 2027 & no action & \\
\hline UPR-200-E-107 & C farm & 2016 & ABAR2ECTF & ET Cap \\
\hline UPR-200-E-108 & B farm & 2026 & ET Cap & \\
\hline UPR-200-E-109 & B farm & 2026 & ET Cap & \\
\hline UPR-200-E-110 & B farm & 2026 & ET Cap & \\
\hline UPR-200-E-141 & Semi-Works & 2017 & RTD & \\
\hline UPR-200-E-16 & C farm & 2016 & ET Cap & \\
\hline UPR-200-E-38 & B farm & 2026 & ET Cap & \\
\hline UPR-200-E-40 & PUREX & 2021 & no action & \\
\hline UPR-200-E-6 & B farm & 2026 & ABAR2EBTF & ET Cap \\
\hline UPR-200-E-73 & B farm & 2026 & ET Cap & \\
\hline UPR-200-E-74 & B farm & 2026 & ET Cap & \\
\hline UPR-200-E-75 & B farm & 2026 & ET Cap & \\
\hline UPR-200-E-81 & C farm & 2016 & ET Cap & \\
\hline UPR-200-E-82 & C farm & 2016 & ET Cap & \\
\hline UPR-200-W-100 & $\mathrm{T}$ farm & 2031 & ET Cap & \\
\hline UPR-200-W-12 & $\mathrm{T}$ farm & 2031 & ET Cap & \\
\hline UPR-200-W-127 & S/U farm & 2028 & RTD / ET Cap & \\
\hline UPR-200-W-132 & S/U farm & 2028 & ET Cap & \\
\hline UPR-200-W-134 & WM & 2023 & ABAR2W12 & \\
\hline UPR-200-W-150 & T farm & 2031 & IBAR & ET Cap \\
\hline UPR-200-W-163 & U plant & 2016 & no action & \\
\hline UPR-200-W-24 & U plant & 2016 & ET Cap & \\
\hline UPR-200-W-52 & $\mathrm{S} / \mathrm{U}$ farm & 2028 & no action & \\
\hline UPR-200-W-74 & PFP & 2017 & no action & \\
\hline UPR-200-W-75 & PFP & 2017 & no action & \\
\hline UPR-200-W-83 & REDOX & 2030 & no action & \\
\hline UPR-200-W-90 & PFP & 2017 & no action & \\
\hline UPR-200-W-95 & 200-W Ponds & 2016 & no action & \\
\hline
\end{tabular}

Assignments made based on review of "All_WIDS_Review_for_CPCP_update.xIs" provided via E-mail Hildebrand (Holten) to Kincaid July 8, 2005

Note: These sites are NOT listed under the tab "In CP Closure"

\section{RIVER CORRIDOR WASTE SITES}

\begin{tabular}{llcll}
\multicolumn{1}{c}{ Zone } & $\begin{array}{c}\text { Completion } \\
\text { Date }\end{array}$ & Remedy \\
$100-B-15$ & $100-B C-1$ & 2003 & RTD \\
$100-B-3$ & $100-B C-1$ & 2003 & RTD \\
$100-B-5$ & $100-B C-1$ & 2004 & RTD \\
$100-B-8$ & $100-B C-1$ & 2004 & RTD \\
$116-B-1$ & $100-B C-1$ & 1999 & RTD \\
$116-B-2$ & $100-B C-1$ & 1999 & RTD \\
$116-B-3$ & $100-B C-1$ & 1999 & RTD \\
$116-B-4$ & $100-B C-1$ & 1997 & RTD \\
$116-B-5$ & $100-B C-1$ & 1997 & RTD \\
$116-B-6 A$ & $100-B C-1$ & 1999 & RTD \\
$116-B-6 B$ & $100-B C-1$ & 1999 & RTD
\end{tabular}




\begin{tabular}{|c|c|c|c|c|}
\hline \multicolumn{4}{|c|}{ Completion } & \multirow{2}{*}{ Notes } \\
\hline 116-B-7 & 100-BC-1 Zone & $\begin{array}{l}\text { Date } \\
2001\end{array}$ & RTD & \\
\hline $116-C-1$ & $100-B C-1$ & 1997 & RTD & \\
\hline 118-B-5 & 100-BC-1 & 2004 & RTD & \\
\hline 118-B-7 & 100-BC-1 & 2004 & RTD & \\
\hline 118-B-8 & 100-BC-1 & 2065 & RTD & \\
\hline 118-B-9 & 100-BC-1 & 2004 & RTD & \\
\hline $132-C-2$ & $100-B C-1$ & 2001 & RTD & \\
\hline $100-C-3$ & $100-B C-2$ & 2005 & RTD & \\
\hline $100-C-6$ & $100-B C-2$ & 2005 & RTD & \\
\hline $116-C-2 A$ & $100-B C-2$ & 1999 & RTD & \\
\hline $116-C-2 C$ & $100-B C-2$ & 1999 & RTD & \\
\hline 118-B-1 & $100-B C-2$ & 2005 & RTD & \\
\hline 118-B-2 & $100-B C-2$ & 2005 & RTD & \\
\hline 118-B-3 & $100-B C-2$ & 2006 & RTD & \\
\hline 118-B-4 & $100-B C-2$ & 2006 & RTD & \\
\hline 118-B-6 & $100-B C-2$ & 2006 & RTD & \\
\hline $118-C-1$ & $100-B C-2$ & 2006 & RTD & \\
\hline $118-C-3$ & $100-B C-2$ & 2065 & RTD & \\
\hline $118-C-4$ & $100-B C-2$ & 2006 & RTD & \\
\hline 120-D-1 & 100-D PONDS & 1996 & RTD & \\
\hline 100-D-24 & 100-DR-1 & 2007 & RTD & \\
\hline 100-D-29 & 100-DR-1 & 2007 & RTD & \\
\hline 100-D-3 & 100-DR-1 & 2007 & RTD & \\
\hline 100-D-32 & 100-DR-1 & 2007 & RTD & \\
\hline 100-D-42 & 100-DR-1 & 2007 & RTD & \\
\hline 100-D-45 & 100-DR-1 & 2007 & RTD & \\
\hline 100-D-49 & 100-DR-1 & 2007 & RTD & \\
\hline 100-D-60 & 100-DR-1 & 2008 & RTD & \\
\hline 100-D-8 & 100-DR-1 & 2008 & RTD & \\
\hline 116-D-1A & 100-DR-1 & 2001 & RTD & \\
\hline 116-D-1B & 100-DR-1 & 2001 & RTD & \\
\hline $116-D-2$ & 100-DR-1 & 1999 & RTD & \\
\hline 116-D-5 & 100-DR-1 & 2008 & RTD & \\
\hline 116-DR-1\%2 & 100-DR-1 & 2000 & RTD & \\
\hline 116-DR-5 & 100-DR-1 & 2008 & RTD & \\
\hline 118-D-6 & 100-DR-1 & 2065 & RTD & \\
\hline 120-D-2 & 100-DR-1 & 2008 & RTD & \\
\hline 100-D-23 & 100-DR-2 & 2009 & RTD & \\
\hline 100-D-40 & 100-DR-2 & 2009 & RTD & \\
\hline 100-D-43 & 100-DR-2 & 2009 & RTD & \\
\hline $100-D-47$ & 100-DR-2 & 2010 & RTD & \\
\hline 100-D-53 & 100-DR-2 & 2010 & RTD & \\
\hline 116-D-8 & 100-DR-2 & 2010 & RTD & \\
\hline 116-DR-3 & 100-DR-2 & 2010 & RTD & \\
\hline 116-DR-4 & 100-DR-2 & 2000 & RTD & \\
\hline 116-DR-6 & 100-DR-2 & 2000 & RTD & \\
\hline 116-DR-8 & 100-DR-2 & 2010 & RTD & \\
\hline 118-D-1 & 100-DR-2 & 2007 & RTD & \\
\hline $118-D-2$ & 100-DR-2 & 2008 & RTD & \\
\hline 118-D-3 & 100-DR-2 & 2008 & RTD & \\
\hline 118-D-4 & 100-DR-2 & 2009 & RTD & \\
\hline 118-D-5 & 100-DR-2 & 2009 & RTD & \\
\hline 118-DR-1 & 100-DR-2 & 2010 & RTD & \\
\hline 118-DR-2 & 100-DR-2 & 2065 & RTD & \\
\hline 122-DR-1 & 100-DR-2 & 2010 & RTD & \\
\hline 132-DR-2 & 100-DR-2 & 2010 & RTD & \\
\hline 100-F-10 & 100-FR-1 & 2003 & RTD & \\
\hline 100-F-12 & 100-FR-1 & 2002 & RTD & \\
\hline 100-F-19 & 100-FR-1 & 2003 & RTD & \\
\hline $100-F-23$ & 100-FR-1 & 2003 & RTD & \\
\hline $100-F-24$ & 100-FR-1 & 2005 & RTD & \\
\hline 100-F-25 & 100-FR-1 & 2005 & RTD & \\
\hline 100-F-29 & 100-FR-1 & 2005 & RTD & \\
\hline 100-F-33 & 100-FR-1 & 2005 & RTD & \\
\hline 100-F-36 & 100-FR-1 & 2005 & RTD & \\
\hline 100-F-37 & 100-FR-1 & 2005 & RTD & \\
\hline
\end{tabular}




\begin{tabular}{|c|c|c|c|c|}
\hline \multicolumn{4}{|c|}{ Completion } & \multirow[b]{2}{*}{ Notes } \\
\hline WIDS Site Code & Zone & Date & Remedy & \\
\hline $100-F-38$ & 100-FR-1 & 2005 & RTD & \\
\hline 100-F-39 & 100-FR-1 & 2005 & RTD & \\
\hline $100-F-9$ & 100-FR-1 & 2006 & RTD & \\
\hline 116-F-1 & 100-FR-1 & 2006 & RTD & \\
\hline 116-F-10 & 100-FR-1 & 2006 & RTD & \\
\hline 116-F-11 & 100-FR-1 & 2006 & RTD & \\
\hline $116-F-16$ & 100-FR-1 & 2006 & RTD & \\
\hline $116-F-2$ & 100-FR-1 & 2002 & RTD & \\
\hline $116-F-3$ & 100-FR-1 & 2006 & RTD & \\
\hline $116-F-4$ & 100-FR-1 & 2001 & RTD & \\
\hline $116-F-5$ & 100-FR-1 & 2001 & RTD & \\
\hline $116-F-6$ & 100-FR-1 & 2006 & RTD & \\
\hline $116-F-7$ & 100-FR-1 & 2006 & RTD & \\
\hline $116-F-8$ & 100-FR-1 & 2006 & RTD & \\
\hline $116-F-9$ & 100-FR-1 & 2002 & RTD & \\
\hline $118-F-8$ & 100-FR-1 & 2065 & RTD & \\
\hline $132-F-5$ & 100-FR-1 & 2007 & RTD & \\
\hline $141-\mathrm{C}$ & 100-FR-1 & 2007 & RTD & \\
\hline UPR-100-F-1 & 100-FR-1 & 2008 & RTD & \\
\hline UPR-100-F-3 & 100-FR-1 & 2008 & RTD & \\
\hline 118-F-1 & 100-FR-2 & 2005 & RTD & \\
\hline 118-F-2 & 100-FR-2 & 2006 & RTD & \\
\hline 118-F-3 & 100-FR-2 & 2006 & RTD & \\
\hline $118-F-4$ & 100-FR-2 & 2007 & RTD & \\
\hline $118-F-5$ & 100-FR-2 & 2007 & RTD & \\
\hline 118-F-6 & 100-FR-2 & 2008 & RTD & \\
\hline 118-F-7 & 100-FR-2 & 2008 & RTD & \\
\hline $100-\mathrm{H}-10$ & 100-HR-1 & 2003 & RTD & \\
\hline $100-\mathrm{H}-12$ & 100-HR-1 & 2007 & RTD & \\
\hline $100-\mathrm{H}-13$ & 100-HR-1 & 2007 & RTD & \\
\hline $100-\mathrm{H}-14$ & 100-HR-1 & 2007 & RTD & \\
\hline $100-\mathrm{H}-31$ & 100-HR-1 & 2008 & RTD & \\
\hline 100-H-33 & 100-HR-1 & 2008 & RTD & \\
\hline $100-\mathrm{H}-34$ & 100-HR-1 & 2008 & RTD & \\
\hline $100-\mathrm{H}-5$ & 100-HR-1 & 2001 & RTD & \\
\hline $100-\mathrm{H}-7$ & 100-HR-1 & 2008 & RTD & \\
\hline $100-\mathrm{H}-8$ & 100-HR-1 & 2008 & RTD & \\
\hline $100-\mathrm{H}-9$ & 100-HR-1 & 2008 & RTD & \\
\hline $116-\mathrm{H}-1$ & 100-HR-1 & 2001 & RTD & \\
\hline $116-\mathrm{H}-2$ & 100-HR-1 & 2001 & RTD & \\
\hline $116-\mathrm{H}-3$ & 100-HR-1 & 2001 & RTD & \\
\hline $116-\mathrm{H}-4$ & 100-HR-1 & 2008 & RTD & \\
\hline $116-\mathrm{H}-5$ & 100-HR-1 & 2009 & RTD & \\
\hline $116-\mathrm{H}-6$ & 100-HR-1 & 1997 & RTD & \\
\hline $116-\mathrm{H}-7$ & 100-HR-1 & 2001 & RTD & \\
\hline $116-\mathrm{H}-9$ & 100-HR-1 & 2009 & RTD & \\
\hline $118-\mathrm{H}-6$ & 100-HR-1 & 2065 & RTD & \\
\hline 118-H-1 & 100-HR-2 & 2007 & RTD & \\
\hline $118-\mathrm{H}-2$ & 100-HR-2 & 2008 & RTD & \\
\hline $118-\mathrm{H}-3$ & 100-HR-2 & 2009 & RTD & \\
\hline $118-\mathrm{H}-4$ & 100-HR-2 & 2009 & RTD & \\
\hline $118-\mathrm{H}-5$ & 100-HR-2 & 2010 & RTD & \\
\hline $600-108$ & 100-IU-6 & 2004 & RTD & \\
\hline $600-111$ & $100-I U-6$ & 2004 & RTD & \\
\hline $100-K-55$ & 100-KR-1 & 2003 & RTD & \\
\hline $100-\mathrm{K}-57$ & $100-K R-1$ & 2003 & RTD & \\
\hline $100-K-78$ & 100-KR-1 & 2003 & RTD & \\
\hline $100-K-80$ & 100-KR-1 & 2003 & RTD & \\
\hline 116-K-1 & 100-KR-1 & 2004 & RTD & \\
\hline $116-\mathrm{K}-2$ & 100-KR-1 & 2004 & RTD & \\
\hline $116-\mathrm{K}-3$ & 100-KR-1 & 2004 & RTD & \\
\hline 116-KE-4 & 100-KR-1 & 2004 & RTD & \\
\hline $116-K W-3$ & 100-KR-1 & 2004 & RTD & \\
\hline 100-K-1 & 100-KR-2 & 2004 & RTD & \\
\hline $100-\mathrm{K}-14$ & 100-KR-2 & 2004 & RTD & \\
\hline $100-\mathrm{K}-2$ & 100-KR-2 & 2004 & RTD & \\
\hline
\end{tabular}




\begin{tabular}{|c|c|c|c|c|}
\hline \multicolumn{4}{|c|}{ Completion } & \multirow[b]{2}{*}{ Notes } \\
\hline WIDS Site Code & Zone & Date & Remedy & \\
\hline $100-\mathrm{K}-36$ & 100-KR-2 & 2009 & RTD & \\
\hline $100-K-38$ & $100-K R-2$ & 2009 & RTD & \\
\hline $100-K-4$ & $100-K R-2$ & 2009 & RTD & \\
\hline $100-K-42$ & $100-K R-2$ & 2009 & RTD & \\
\hline $100-K-43$ & $100-K R-2$ & 2009 & RTD & \\
\hline $100-K-46$ & $100-K R-2$ & 2009 & RTD & \\
\hline $100-K-5$ & $100-K R-2$ & 2009 & RTD & \\
\hline $100-K-56$ & $100-K R-2$ & 2009 & RTD & \\
\hline $100-K-6$ & $100-K R-2$ & 2009 & RTD & \\
\hline $100-K-61$ & $100-K R-2$ & 2009 & RTD & \\
\hline $100-K-62$ & $100-K R-2$ & 2009 & RTD & \\
\hline 116-KE-1 & $100-K R-2$ & 2010 & RTD & \\
\hline 116-KE-2 & $100-K R-2$ & 2010 & RTD & \\
\hline 116-KE-3 & $100-K R-2$ & 2010 & RTD & \\
\hline 116-KE-5 & $100-K R-2$ & 2010 & RTD & \\
\hline 116-KE-6D & $100-K R-2$ & 2010 & RTD & \\
\hline $116-K W-1$ & $100-K R-2$ & 2010 & RTD & \\
\hline $116-K W-2$ & $100-K R-2$ & 2010 & RTD & \\
\hline 116-KW-4 & $100-K R-2$ & 2010 & RTD & \\
\hline $118-\mathrm{K}-1$ & $100-K R-2$ & 2010 & RTD & \\
\hline 118-KE-1 & $100-K R-2$ & 2065 & RTD & \\
\hline 118-KE-2 & $100-K R-2$ & 2010 & RTD & \\
\hline 118-KW-1 & $100-K R-2$ & 2065 & RTD & \\
\hline 118-KW-2 & $100-K R-2$ & 2010 & RTD & \\
\hline 120-KE-2 & $100-K R-2$ & 2010 & RTD & \\
\hline 120-KE-3 & $100-K R-2$ & 2010 & RTD & \\
\hline 120-KW-2 & $100-K R-2$ & 2011 & RTD & \\
\hline UPR-100-K-1 & $100-K R-2$ & 2011 & RTD & \\
\hline $100-N-1$ & 100-NR-1 & 2003 & RTD & \\
\hline $100-N-29$ & 100-NR-1 & 2003 & RTD & \\
\hline $100-N-54$ & 100-NR-1 & 2009 & RTD & \\
\hline $100-N-55$ & 100-NR-1 & 2009 & RTD & \\
\hline $100-N-59$ & 100-NR-1 & 2009 & RTD & \\
\hline $100-N-60$ & 100-NR-1 & 2010 & RTD & \\
\hline $100-N-62$ & 100-NR-1 & 2010 & RTD & \\
\hline $100-N-63$ & 100-NR-1 & 2010 & RTD & \\
\hline $100-N-64$ & 100-NR-1 & 2010 & RTD & \\
\hline $100-N-66$ & 100-NR-1 & 2065 & RTD & \\
\hline $116-\mathrm{N}-4$ & 100-NR-1 & 2010 & RTD & \\
\hline $120-N-3$ & 100-NR-1 & 2010 & RTD & \\
\hline $120-N-7$ & 100-NR-1 & 2010 & RTD & \\
\hline $124-N-10$ & 100-NR-1 & 2010 & RTD & \\
\hline UPR-100-N-1 & 100-NR-1 & 2011 & RTD & \\
\hline UPR-100-N-10 & 100-NR-1 & 2011 & RTD & \\
\hline UPR-100-N-12 & 100-NR-1 & 2011 & RTD & \\
\hline UPR-100-N-25 & 100-NR-1 & 2011 & RTD & \\
\hline UPR-100-N-30 & 100-NR-1 & 2012 & RTD & \\
\hline UPR-100-N-35 & 100-NR-1 & 2012 & RTD & \\
\hline UPR-100-N-5 & $100-N R-1$ & 2012 & RTD & \\
\hline UPR-100-N-7 & 100-NR-1 & 2012 & RTD & \\
\hline UPR-100-N-8 & 100-NR-1 & 2012 & RTD & \\
\hline & 100-NR-1 (TSD SITES & & & \\
\hline $116-\mathrm{N}-1$ & $\mathrm{RA})$ & 2012 & RTD & \\
\hline & 100-NR-1 (TSD SITES & & & \\
\hline $116-N-3$ & $\mathrm{RA})$ & 2002 & RTD & \\
\hline & 100-NR-1 (TSD SITES & & & \\
\hline $120-\mathrm{N}-1$ & $\mathrm{RA})$ & 2001 & RTD & \\
\hline & 100-NR-1 (TSD SITES & & & \\
\hline $120-\mathrm{N}-2$ & $\mathrm{RA})$ & 2001 & RTD & \\
\hline & 100-NR-1 (TSD SITES & & & \\
\hline UPR-100-N-31 & $\mathrm{RA})$ & 2012 & RTD & \\
\hline 300_ASH_PITS & $300-F F-1$ & 1997 & no action & \\
\hline 300_RFBP & 300-FF-1 & 2001 & no action & \\
\hline $316-1$ & 300-FF-1 & 2001 & RTD & \\
\hline $316-2$ & 300-FF-1 & 1999 & RTD & \\
\hline $316-5$ & 300-FF-1 & 1998 & RTD & \\
\hline
\end{tabular}




\begin{tabular}{|c|c|c|c|c|}
\hline \multirow[b]{2}{*}{ WIDS Site Code } & \multicolumn{3}{|c|}{ Completion } & \multirow[b]{2}{*}{ Notes } \\
\hline & Zone & Date & Remedy & \\
\hline $618-4$ & 300-FF-1 & 2003 & RTD & \\
\hline UPR-300-32 & $300-F F-1$ & 2001 & RTD & \\
\hline UPR-300-34 & $300-F F-1$ & 2001 & RTD & \\
\hline UPR-300-36 & $300-F F-1$ & 2001 & RTD & \\
\hline UPR-300-37 & $300-F F-1$ & 2001 & RTD & \\
\hline UPR-300-FF-1 & $300-F F-1$ & 2003 & RTD & \\
\hline 4843 & $300-F F-2$ & 1995 & RTD & \\
\hline 300_VTS & $300-F F-2$ & 2012 & RTD & \\
\hline $300-121$ & $300-F F-2$ & 2003 & RTD & \\
\hline $300-2$ & $300-F F-2$ & 2004 & RTD & \\
\hline $300-249$ & $300-F F-2$ & 2004 & RTD & \\
\hline $300-25$ & $300-F F-2$ & 2005 & RTD & \\
\hline $300-264$ & $300-F F-2$ & 2005 & RTD & \\
\hline $300-265$ & $300-F F-2$ & 2005 & RTD & \\
\hline $300-270$ & $300-F F-2$ & 2006 & RTD & \\
\hline 300-39 & $300-F F-2$ & 2007 & RTD & \\
\hline 307_RB & $300-F F-2$ & 2007 & RTD & \\
\hline 309-WS-1 & $300-F F-2$ & 2009 & RTD & \\
\hline 309-WS-2 & $300-F F-2$ & 2009 & RTD & \\
\hline $316-4$ & $300-F F-2$ & 2006 & RTD & \\
\hline 331_LSLDF & $300-F F-2$ & 2010 & RTD & \\
\hline 331_LSLT2 & $300-F F-2$ & 2011 & RTD & \\
\hline 3712_USSA & $300-F F-2$ & 2011 & RTD & \\
\hline $600-259$ & $300-F F-2$ & 2012 & RTD & \\
\hline $618-10$ & $300-F F-2$ & 2011 & RTD & \\
\hline $618-11$ & $300-F F-2$ & 2012 & RTD & \\
\hline $618-13$ & $300-F F-2$ & 2012 & RTD & \\
\hline $618-2$ & $300-F F-2$ & 2006 & RTD & \\
\hline $618-3$ & $300-F F-2$ & 2006 & RTD & \\
\hline $618-5$ & $300-F F-2$ & 2008 & RTD & \\
\hline $618-7$ & $300-F F-2$ & 2008 & RTD & \\
\hline $618-8$ & $300-F F-2$ & 2012 & RTD & \\
\hline $618-9$ & $300-F F-2$ & 1991 & RTD & \\
\hline UPR-300-10 & $300-F F-2$ & 2012 & RTD & \\
\hline UPR-300-12 & $300-F F-2$ & 2012 & RTD & \\
\hline UPR-300-48 & $300-F F-2$ & 2012 & RTD & \\
\hline 300_RLWS & RA ACP - 300-FF-2 & 2004 & RTD & \\
\hline 300_RRLWS & RA ACP - 300-FF-2 & 2004 & RTD & \\
\hline $300-16$ & RA ACP - 300-FF-2 & 2005 & RTD & \\
\hline $300-214$ & RA ACP - 300-FF-2 & 2006 & RTD & \\
\hline $300-224$ & RA ACP - 300-FF-2 & 2006 & RTD & \\
\hline $300-24$ & RA ACP - 300-FF-2 & 2006 & RTD & \\
\hline $300-251$ & RA ACP - 300-FF-2 & 2007 & RTD & \\
\hline $300-255$ & RA ACP - 300-FF-2 & 2007 & RTD & \\
\hline $300-262$ & RA ACP - 300-FF-2 & 2001 & RTD & \\
\hline $300-28$ & RA ACP - 300-FF-2 & 2008 & RTD & \\
\hline $300-33$ & RA ACP - 300-FF-2 & 2009 & RTD & \\
\hline $300-4$ & RA ACP - 300-FF-2 & 2009 & RTD & \\
\hline $300-40$ & RA ACP - 300-FF-2 & 2009 & RTD & \\
\hline $300-48$ & RA ACP - 300-FF-2 & 2010 & RTD & \\
\hline $300-80$ & RA ACP - 300-FF-2 & 2010 & RTD & \\
\hline 303-M-SA & RA ACP - 300-FF-2 & 2010 & RTD & \\
\hline 303-M-UOF & RA ACP - 300-FF-2 & 2010 & RTD & \\
\hline 313_ESSP & RA ACP - 300-FF-2 & 2010 & RTD & \\
\hline $316-3$ & RA ACP - 300-FF-2 & 2011 & RTD & \\
\hline 333_ESHWSA & RA ACP - 300-FF-2 & 2011 & RTD & \\
\hline $618-1$ & RA ACP - 300-FF-2 & 2010 & RTD & \\
\hline UPR-300-1 & RA ACP - 300-FF-2 & 2011 & RTD & \\
\hline UPR-300-11 & RA ACP - 300-FF-2 & 2011 & RTD & \\
\hline UPR-300-2 & RA ACP - 300-FF-2 & 2011 & RTD & \\
\hline UPR-300-38 & RA ACP - 300-FF-2 & 2012 & RTD & \\
\hline UPR-300-39 & RA ACP - 300-FF-2 & 2012 & RTD & \\
\hline UPR-300-4 & RA ACP - 300-FF-2 & 2012 & RTD & \\
\hline UPR-300-40 & RA ACP - 300-FF-2 & 2012 & RTD & \\
\hline UPR-300-45 & RA ACP - 300-FF-2 & 2012 & RTD & \\
\hline UPR-300-5 & RA ACP - 300-FF-2 & 2012 & RTD & \\
\hline
\end{tabular}




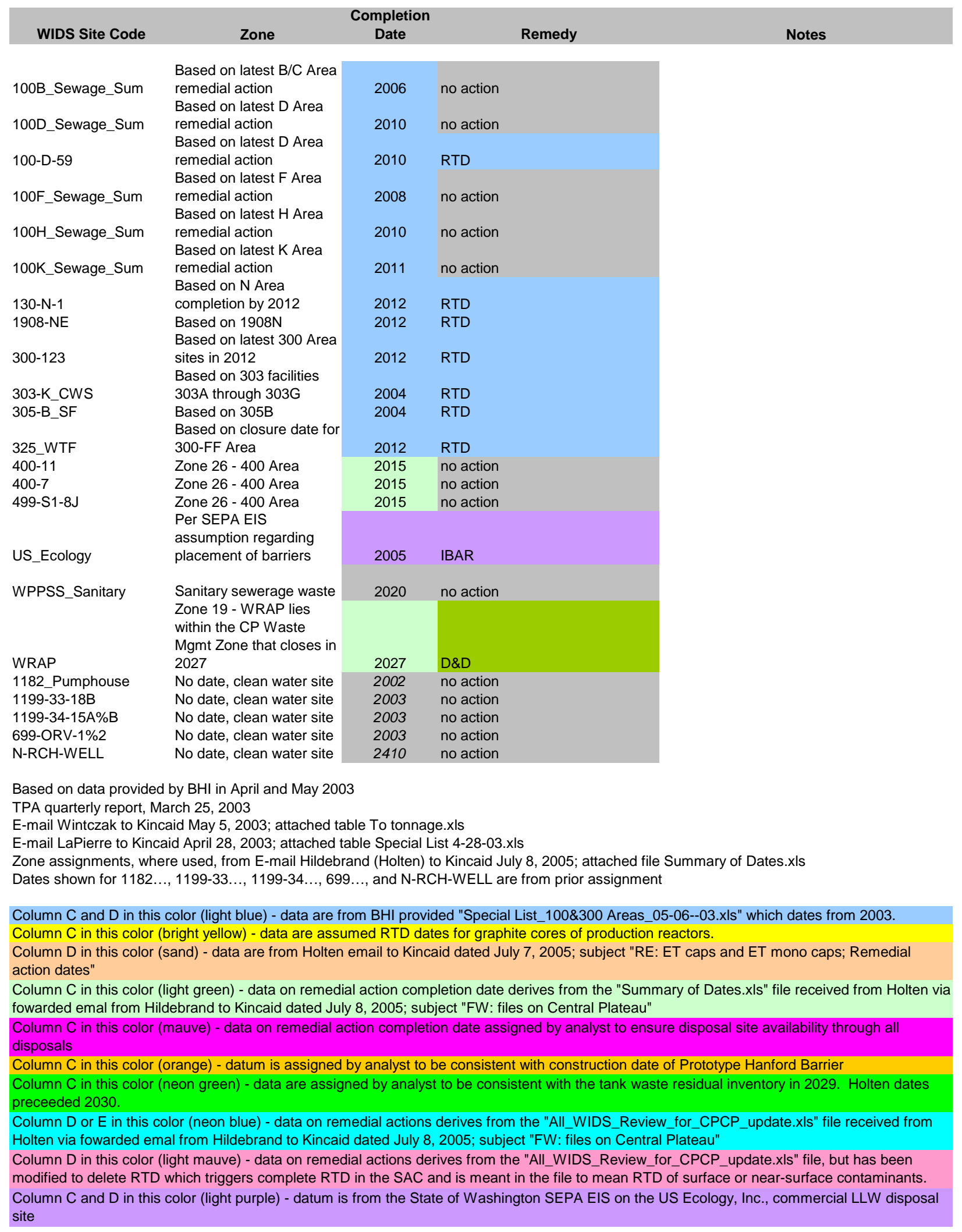


ABAR w/A-AN-AX-AY-Až aggregated barrier covering A-AN-AX-AY-AZ tank farms

ABAR W/AP WMA aggregated barrier covering AP tank farm

ABAR W/AW WMA aggregated barrier covering AW tank farm

ABAR w/B-BX-BY WMA aggregated barrier covering B-BX-BY tank farm

ABAR2EBTF aggregated barrier covering B-BX-BY tank farm

ABAR w/C WMA aggregated barrier covering $C$ tank farm

ABAR2ECTF aggregated barrier covering $C$ tank farm

ABAR W/S-SX-SY WMA aggregated barrier covering S-SX-SY tank farm

ABAR W/T WMA aggregated barrier covering T tank farm

ABAR W/TX-TY WMA aggregated barrier covering TX-TY tank farm

ABAR W/U WMA aggregated barrier covering $U$ tank farm

ABAR2E01

ABAR2E02

ABAR2E03

ABAR2E04

ABAR2E05

ABAR2E06

ABAR2E07

ABAR2E08

ABAR2E09

ABAR2E10/PUREX

ABAR2E12

ABAR2E13

ABAR2E14

ABAR2E16

ABAR2E17

ABAR2W01

ABAR2W02

ABAR2W03

ABAR2W04

ABAR2W05

ABAR2W06

ABAR2W07/PFP

ABAR2W08

ABAR2W09

ABAR2W10

ABAR2W11

ABAR2W12/231-Z

ABAR2W13 aggregated barrier in NRDWL/BC Control Zone; covers 216-B-29 thru B-34 aggregated barrier within B Plant Zone aggregated barrier within B Plant Zone aggregated barrier in NRDWL/BC Control Zone; covers 216-B-23 thru B-28, \& B-52 aggregated barrier in NRDWL/BC Control Zone; covers 216-B-20 thru B-22 aggregated barrier in NRDWL/BC Control Zone; covers 216-B-14 thru B-19, \& 200-E-14 aggregated barrier within PUREX Zone; covers 216-A-38-1 and vicinity aggregated barrier within $200 \mathrm{E}$ Ponds Zone aggregated barrier within $200 \mathrm{E}$ Ponds Zone aggregated barrier within PUREX Zone; covers PUREX and vicinity aggregated barrier within Solid Waste Zone; covers 218-E-8 and -12B and vicinity aggregated barrier in B Farm Zone; covers BY cribs and 216-B-50 aggregated barrier within Solid Waste Zone; covers 218-E-2, $-2 A,-5,-5 A,-9$ and vicinity aggregated barrier within B Farm Zone, covers BX trenches aggregated barrier within Semi-Works Zone

aggregated barrier within WM Zone; covers northern portion of WM Zone burial grounds aggregated barrier within T Farm Zone; 216-T-14 thru -17 aggregated barrier within T Farm Zone, covers T farm WMA aggregated barrier within T Farm Zone; covers 216-T-26 thru -28 aggregated barrier within T Farm Zone; covers 216-T-21 thru -25 aggregated barrier within WM Zone; covers 218-W-1, -2, -4B aggregated barrier within PFP Zone, covers PFP facility and vicinity aggregated barrier within T Plant Zone; covers 216-T-9 thru -11 aggregated barrier within 200 W Ponds Zone; covers 216-U-10 (U Pond) and vicinity aggregated barrier within PFP Zone; covers $Z$ ditches and vicinity aggregated barrier within $200 \mathrm{~W}$ Ponds Zone; covers $216-\mathrm{S}-17$ pond and vicinity aggregated barrier within PFP Zone, covers $231-Z$ facility and vicinity aggregated barrier within T Farm Zone 
Appendix B

Inventory Attribute Spreadsheet 


\section{Appendix B}

\section{Inventory Attribute Spreadsheet}

Many of the attributes of the inventory data set are contained in a single file (Microsoft ${ }^{1}{ }^{1}$ Excel format) named 'Attributes_2006-01-04_DCR-0029.xls' that is under configuration management and maintained on the System Assessment Capability (SAC) Windows File server at IIsac.pnl.gov\shareldatałrev.1 inventory\. Data in the file are grouped into seven worksheets. The worksheet titles and contents are the following:

- Cover: The cover worksheet contains a brief history of changes to data entries in the file. It does not contain any primary data.

- ATTRIBUTE Keywords: This worksheet contains the data required to generate ATTRIBUTE keywords for the INPROC computer code (Eslinger et al. 2004) (a preprocessor to the INVENTORY code). The data entries include the subsite code from the inventory database, the meaning of the subsite code, and the release model to apply for the waste type. The ATTRIBUTE keywords are developed in this worksheet as well.

- WASTYPE Keywords: This workbook references data in the 'ATTRIBUTE Keywords' worksheet and develops WASTYPE keywords for use in the INPROC code.

- SELECT Keywords: This workbook references data in the 'ATTRIBUTE Keywords' worksheet and develops SELECT keywords for use in the INVENTORY code.

- SURROGATE Keywords: This workbook contains the primary data needed for application of surrogate rules. The SURROGATE keywords are developed in this worksheet for use in the INPROC code.

- AGGREGATION Site: The inventory codes allow the inventory for multiple waste sites to be aggregated into a smaller number of sites. For this application, the inventory is developed and used for each site explicitly and no aggregation rules are applied. Information in this worksheet is used to develop the aggregation data for use in the INPROC code.

- Estimation Rules: The estimation rules defined in Section 4.0 are applied on a waste site basis. This workbook contains the primary data identifying which estimation rule, if any, is applied to each site. These data are extracted and exported for use in the INPROC code.

Eslinger, PW, DW Engel, LH Gerhardstein, CA Lo Presti, TB Miley, WE Nichols, DL Strenge, and SK Wurstner. 2004. User Instructions for the Systems Assessment Capability, Rev. 1, Computer Codes. Volume 1: Inventory, Release, and Transport Modules. PNNL-14852, Volume 1, Pacific Northwest National Laboratory, Richland, Washington.

\footnotetext{
${ }^{1}$ Microsoft Corporation, Redmond, Washington.
} 


\section{Appendix C}

\section{Application of Surrogate Site Rules}




\section{Appendix C}

\section{Application of Surrogate Site Rules}

This appendix describes the surrogate rules applied to waste sites. The information provided here is a short summary of the detailed information in worksheet 'SURROGATE Keywords' of the attribute spreadsheet described in Appendix B. The waste stream at a site always has the same type as the waste stream at the surrogate waste site. The 'UTN' and 'STN' designators both indicate soil waste forms. The 'upr' designator (unplanned release) indicates a liquid waste form. Surrogate site rules were applied to the following sites:

- 100-B-5: Surrogate site rules were applied for 1954 through 1956 with a volume of $24,150 \mathrm{~m}^{3}$ each year. The surrogate site was 116-B-1 and the surrogate waste was a liquid waste stream in 1951.

- 100-D-3: Surrogate site rules were applied for 1944 through 1967 with a volume of $434.782 \mathrm{~m}^{3}$ each year. The surrogate site was 118-D-2 and the surrogate waste was a UTN waste stream in 1956.

- 100-D-32: Surrogate site rules were applied for 1956 through 1967 with a volume of $434.782 \mathrm{~m}^{3}$ each year. The surrogate site was 118-D-2 and the surrogate waste was a UTN waste stream in 1956.

- 100-D-40: Surrogate site rules were applied for 1944 through 1967 with a volume of $434.782 \mathrm{~m}^{3}$ each year. The surrogate site was 118-D-2 and the surrogate waste was a UTN waste stream in 1956.

- 100-D-47: Surrogate site rules were applied for 1944 through 1967 with a volume of $434.782 \mathrm{~m}^{3}$ each year. The surrogate site was 118-D-2 and the surrogate waste was a UTN waste stream in 1956.

- 100-F-23: Surrogate site rules were applied for 1944 through 1965 with a volume of $6.43518 \mathrm{~m}^{3}$ each year. The surrogate site was UPR-100-F-1 and the surrogate waste was an unplanned release waste stream in 1971.

- 100-F-25: Surrogate site rules were applied for 1944 through 1965 with a volume of $25.903 \mathrm{~m}^{3}$ each year. The surrogate site was 2101-M-Pond and the surrogate waste was a liquid waste stream in 1974.

- 100-F-36: A surrogate site rule was applied for 1973 with a volume of $363.636 \mathrm{~m}^{3}$. The surrogate site was 118-F-5 and the surrogate waste was a UTN waste stream in 1964.

- 100-H-10: Surrogate site rules were applied for 1949 through 1965 with a volume of $25 \mathrm{~m}^{3}$ each year. The surrogate site was 116-B-4 and the surrogate waste was a liquid waste stream in 1960.

- 100-H-7: Surrogate site rules were applied for 1949 through 1965 with a volume of $25 \mathrm{~m}^{3}$ each year. The surrogate site was 116-B-4 and the surrogate waste was a liquid waste stream in 1960 . 
- 100-H-8: Surrogate site rules were applied for 1949 through 1965 with a volume of $25 \mathrm{~m}^{3}$ each year. The surrogate site was 116-B-4 and the surrogate waste was a liquid waste stream in 1960.

- 100-H-9: Surrogate site rules were applied for 1949 through 1965 with a volume of $25 \mathrm{~m}^{3}$ each year. The surrogate site was 116-B-4 and the surrogate waste was a liquid waste stream in 1960.

- 100-K-2: Surrogate site rules were applied for 1955 through 1971 with a volume of 7,345 $\mathrm{m}^{3}$ each year. The surrogate site was 116-B-4 and the surrogate waste was a soil waste stream in 1953.

- 100-K-5: Surrogate site rules were applied for 1955 through 1971 with a volume of $18.191 \mathrm{~m}^{3}$ each year. The surrogate site was 116-K-2 and the surrogate waste was a liquid waste stream in 1963.

- 100-N-60: Surrogate site rules were applied for 1963 through 1987 with a volume of $0.28387 \mathrm{~m}^{3}$ each year. The surrogate site was 116-B-4 and the surrogate waste was a liquid waste stream in 1960.

- 100-DR-8: Surrogate site rules were applied for 1960 through 1964 with a volume of $48 \mathrm{~m}^{3}$ each year. The surrogate site was 116-F-7 and the surrogate waste was a liquid waste stream in 1963 .

- 116-F-11: Surrogate site rules were applied for 1953 through 1965 with a volume of $15.3846 \mathrm{~m}^{3}$ each year. The surrogate site was $116-\mathrm{F}-10$ and the surrogate waste was a liquid waste stream in 1956.

- 116-F-16: Surrogate site rules were applied for 1944 through 1965 with a volume of $2,142.857 \mathrm{~m}^{3}$ each year. The surrogate site was 116-F-9 and the surrogate waste was a liquid waste stream in 1970.

- 116-H-9: Surrogate site rules were applied for 1960 through 1965 with a volume of $50 \mathrm{~m}^{3}$ each year. The surrogate site was 116-F-7 and the surrogate waste was a liquid waste stream in 1963.

- 116-KE-3: Surrogate site rules were applied for 1955 through 1971 with a volume of $17.647 \mathrm{~m}^{3}$ each year. The surrogate site was $116-\mathrm{KE}-2$ and the surrogate waste was a liquid waste stream in 1960.

- 116-KW-2: Surrogate site rules were applied for 1955 through 1970 with a volume of $17.647 \mathrm{~m}^{3}$ each year. The surrogate site was $116-\mathrm{KE}-2$ and the surrogate waste was a liquid waste stream in 1960.

- 118-B-7: Surrogate site rules were applied for 1951 through 1968 with a volume of $434.782 \mathrm{~m}^{3}$ each year. The surrogate site was 118-B-1 and the surrogate waste was a UTN waste stream in 1960.

- 118-C-4: Surrogate site rules were applied for 1950 through 1969 with a volume of $434.782 \mathrm{~m}^{3}$ each year. The surrogate site was 118-C-1 and the surrogate waste was a UTN waste stream in 1956.

- 118-D-1: Surrogate site rules were applied for 1944 through 1967 with a volume of $416.666 \mathrm{~m}^{3}$ each year. The surrogate site was 118-D-2 and the surrogate waste was a UTN waste stream in 1956. 
- 118-D-4: Surrogate site rules were applied for 1953 through 1967 with a volume of $1,333.333 \mathrm{~m}^{3}$ each year. The surrogate site was 118-D-2 and the surrogate waste was a UTN waste stream in 1956.

- 118-KW-2: Surrogate site rules were applied for 1955 through 1971 with a volume of $434.782 \mathrm{~m}^{3}$ each year. The surrogate site was 118-C-1 and the surrogate waste was a UTN waste stream in 1956.

- 200-E-102: A surrogate site rule was applied for 1958 with a volume of $1,661 \mathrm{~m}^{3}$. The surrogate site was 216-A-4 and the surrogate waste was a liquid waste stream in 1956.

- 200-W-40: A surrogate site rule was applied for 1990 with a volume of $535 \mathrm{~m}^{3}$. The surrogate site was $218-\mathrm{W}-3 \mathrm{~A}$ and the surrogate waste was a liquid waste stream in 1991.

- 200-W-52: Surrogate site rules were applied for 1948 through 1955 with a volume of 11,900 $\mathrm{m}^{3}$ each year. The surrogate site was 216-T-19 and the surrogate waste was a liquid waste stream in 1952.

- 200-W-69: A surrogate site rule was applied for 2000 with a volume of $535 \mathrm{~m}^{3}$. The surrogate site was 218-W-3A and the surrogate waste was a STN waste stream in 1991.

- 216-SX-2: Surrogate site rules were applied for 1952 through 1965 with a volume of 5,882.3 $\mathrm{m}^{3}$ each year. The surrogate site was 216-A-11 and the surrogate waste was a liquid waste stream in 1964.

- 216-T-10: Surrogate site rules were applied for 1951 through 1954 with a volume of $98.4 \mathrm{~m}^{3}$ each year. The surrogate site was 216-S-18 and the surrogate waste was a liquid waste stream in 1954 .

- 216-T-11: Surrogate site rules were applied for 1951 through 1954 with a volume of $98.4 \mathrm{~m}^{3}$ each year. The surrogate site was 216-S-18 and the surrogate waste was a liquid waste stream in 1954 .

- 216-T-9: Surrogate site rules were applied for 1951 through 1954 with a volume of $98.4 \mathrm{~m}^{3}$ each year. The surrogate site was 216-S-18 and the surrogate waste was a liquid waste stream in 1954 .

- 216-TY-201: Surrogate site rules were applied for 1953 through 1966 with a volume of $6.2 \mathrm{~m}^{3}$ each year. The surrogate site was 216-T-28 and the surrogate waste was a liquid waste stream in 1966.

- 218-C-9: A surrogate site rule was applied for 1989 with a volume of $2,265 \mathrm{~m}^{3}$. The surrogate site was 218-E-8 and the surrogate waste was a UTN waste stream in 1958.

- 218-E-2A: Surrogate site rules were applied for 1945 through 1950 with a volume of $1,557.435 \mathrm{~m}^{3}$ each year. The surrogate site was 218-E-5 and the surrogate waste was a UTN waste stream in 1955.

- 218-W-11: A surrogate site rule was applied for 1960 with a volume of $1,160 \mathrm{~m}^{3}$. The surrogate site was 218-W-4A and the surrogate waste was a UTN waste stream in 1964.

- 231-Z: A surrogate site rule was applied for 2000 with a volume of $1 \mathrm{~m}^{3}$. The surrogate site was 234-5Z and the surrogate waste was a PPL waste stream in 1996. 
- 276-S: A surrogate site rule was applied for 1967 with a volume of $175,000 \mathrm{~m}^{3}$. The surrogate site was 202-S and the surrogate waste was a cement waste stream in 1968.

- 293-S: A surrogate site rule was applied for 1967 with a volume of $175,000 \mathrm{~m}^{3}$. The surrogate site was 202-S and the surrogate waste was a cement waste stream in 1968.

- 300-224: Surrogate site rules were applied for 1960 through 1988 with a volume of $1,195.7 \mathrm{~m}^{3}$ each year. The surrogate site was 316-1 and the surrogate waste was a liquid waste stream in 1966.

- 300-24: A surrogate site rule was applied for 1994 with a volume of $15.73 \mathrm{~m}^{3}$. The surrogate site was 618-5 and the surrogate waste was a UTN waste stream in 1954.

- 300-28: A surrogate site rule was applied for 1994 with a volume of $15.73 \mathrm{~m}^{3}$. The surrogate site was 618-5 and the surrogate waste was a UTN waste stream in 1954.

- 316-3: Surrogate site rules were applied for 1953 through 1963 with a volume of $90,909.09 \mathrm{~m}^{3}$ each year. The surrogate site was 316-2 and the surrogate waste was a liquid waste stream in 1966.

- 331_LSLT2: Surrogate site rules were applied for 1966 through 1974 with a volume of $21,428.571 \mathrm{~m}^{3}$ each year. The surrogate site was $116-\mathrm{F}-9$ and the surrogate waste was a liquid waste stream in 1970.

- 618-13: A surrogate site rule was applied for 1950 with a volume of $3,398 \mathrm{~m}^{3}$. The surrogate site was 618-3 and the surrogate waste was a UTN waste stream in 1955.

- GTF: A surrogate site rule was applied for 1991 with a volume of $2 \mathrm{~m}^{3}$. The surrogate site was GTFL and the surrogate waste was a cement waste stream in 1988.

- UPR-100-N-1: A surrogate site rule was applied for 1974 with a volume of $113.55 \mathrm{~m}^{3}$. The surrogate site was 116-N-1 and the surrogate waste was a liquid waste stream in 1974.

- UPR-100-N-25: A surrogate site rule was applied for 1975 with a volume of $1.8927 \mathrm{~m}^{3}$. The surrogate site was 116-N-1 and the surrogate waste was a liquid waste stream in 1974.

- UPR-100-N-30: A surrogate site rule was applied for 1974 with a volume of $9.4635 \mathrm{~m}^{3}$. The surrogate site was 116-N-1 and the surrogate waste was a liquid waste stream in 1974.

- UPR-100-N-5: A surrogate site rule was applied for 1972 with a volume of $340.65 \mathrm{~m}^{3}$. The surrogate site was 116-N-1 and the surrogate waste was a liquid waste stream in 1974. 
Appendix D

Tritium Inventories Associated with Tritium Production 


\title{
Appendix D
}

\section{Tritium Inventories Associated with Tritium Production}

\author{
John Evans
}

Tritium is produced in nuclear operations by a variety of different process. The first section of this appendix discusses all significant production mechanisms of interest at Hanford. Of special interest here are the two campaigns specifically designed to produce tritium as a product. Neither of the two tritium production campaigns were documented with adequate detail to make absolutely firm estimates of residual tritium inventories; the issue is further complicated by uncertainties concerning the chemical form of the tritium containing waste. This appendix is intended to summarize what information is known and provide a crude basis for estimating inventories.

\section{D.1 Tritium Production Mechanisms}

Naturally occurring tritium is produced at low, but measurable levels, through the action of highenergy cosmic rays on the principal components of the atmosphere (nitrogen, oxygen, and argon). The process is referred to as spallation and accounts for tritium levels of 50-100 pCi/L comprising a natural background always present in surface water, shallow groundwater, or precipitation. Most of the tritium found in the Columbia River both upstream and downstream from Hanford today is from that source. In the mid 1960s, fallout from atmospheric nuclear weapons testing was responsible for elevating those background levels by several orders of magnitude; however, that signal has since decreased markedly through dispersal and decay.

On the Hanford Site, irradiation of uranium fuel elements in the plutonium production reactors produced tritium in the fuel by a process called ternary fission. The yield for ternary fission is relatively low compared to the more familiar binary fission process responsible for producing persistent fission product contaminants such as cesium-137, but is nonetheless quite significant. Ternary fissions resulting in the formation of residual tritium nuclei account for about $0.2 \%$ of all fission events. Decladding and dissolution of the fuel released the stored tritium, which equilibrated with the dissolver water. Part of the tritium was then released to the soil column through process condensate disposal to cribs or to the atmosphere as evaporator discharge with only part of the residue going to tanks. The majority of the tritium occurring in Hanford groundwater at the present time is associated with that type of process. Because of the large volumes of water involved, some of these plumes are very large and occur at numerous locations. The largest plume, which extends eastward from the Plutonium-Uranium Extraction (PUREX) Plant cribs in the 200 East Area to the Columbia River, covers a wide area including the Hanford town site and 618-11 burial ground. Tritium concentrations associated with process condensate discharges can be as high as $2,000,000 \mathrm{pCi} / \mathrm{L}$ or more near the point of discharge but are significantly reduced by decay and dispersion over the transport path. Process condensate plumes also contain co-contaminants at readily measurable levels. Nitrate and iodine-129 measured in conjunction with tritium provide the best signatures for a process condensate derived plume. Since tritium and nitrate move essentially unretarded in the groundwater system, the occurrence of tritium without a corresponding nitrate signature can provide conclusive evidence that the tritium originated from a source other than process condensate. 
During reactor operation, some tritium is produced in the cooling water through neutron capture on the deuterium in the water. Because the neutron capture cross-section of deuterium is very small ( 0.00053 barns), that process is not very efficient. That is, of course, the main reason for using heavy water as a coolant in the first place. It is relatively transparent to thermal neutrons. Reactors such as the production reactors at Savannah River or the Canadian commercial CANDU reactors, which employ heavy water as moderator/coolant, can produce a significant inventory of tritium by neutron capture on deuterium simply because there is a lot of target and a long irradiation time; however, since the Hanford reactors used once-through cooling with light water which contains only $0.015 \%$ deuterium (relative to hydrogen), buildup of tritium was essentially negligible and relatively little tritium attributable to that source has been observed near the old reactors. Some tritium release has been observed from N Reactor though which employed a light-water, closed loop, feed-and-bleed type cooling water cycle.

Neutron bombardment of helium-3 can also produce tritium since helium-3 has an extremely large neutron capture cross-section for tritium production (5,530 barns). Tritium can, thus, be produced in surprisingly large quantities from the minute amounts of helium-3 found in ordinary helium when helium gas is used as an inert reactor blanket as was commonly the practice in the graphite reactors. Tritium plumes near the KE and KW Reactors in particular may have originated from that type of source.

Most national security applications involving tritium production for weapons use have been conducted in the past at the Savannah River Site. Technical and operational details of that work are classified. The earliest work involving tritium production by bombardment of lithium was, however, performed at Hanford using the B and $\mathrm{H}$ Reactors for irradiation of lithium-aluminum alloy targets. That work, referred to as Project P-10-X, was carried out during the 1949 to 1952 time period producing the tritium used in the very earliest tests of thermonuclear devices. Tritium extraction was carried out in a dedicated laboratory near the B Reactor, the 108-B Building or Chemical Pump House. That facility has since been demolished. The disposition of waste associated with that project is described in the Waste Information Data System (WIDS) under waste site 132-B-1 (also known as 108-B Tritium Separations

Facility). In the mid-1960s, a project known as the Hanford Coproduct Program was undertaken that also produced some tritium for fusion energy research.

\section{D.2 Project P-10-X (1949-1954)}

History. Starting in February 1949, a pilot program for producing large quantities of tritium was transferred from Argonne National Laboratory to the 100-B Area at Hanford. The project was originally code-named P-10 and by late 1950 was renamed as Project P-10-X. All tritium production subsequent to August 1954 was done at the Savannah River Plant. Operation of Project P-10-X began in 1949 with irradiations of lithium fluoride slugs. Experiments with lithium fluoride were terminated in May 1949 as a result of "pile irradiation difficulties" that were almost certainly associated with production of hydrogen fluoride. All subsequent work starting in August 1949 was done using lithium-aluminum alloy rods. Irradiations were done in either $\mathrm{H}$ or B Reactor. Vacuum extraction of tritium as gaseous $\mathrm{T}_{2}$ was performed on the irradiated rods in the modified 108-B Chemical Pump House. Palladium thimbles were used to isolate and purify the $\mathrm{T}_{2}$ gas, which was collected in mercury driven Toepler pumps. The produced tritium gas was placed in flasks and shipped to Los Alamos for further processing and use. During its five years of operation, Project P-10-X extracted more than 11 million Ci of tritium representing a delivered amount of product of about $1.2 \mathrm{~kg}$. The $108-\mathrm{B}$ facility was located north of the main 105-B Reactor building and was demolished in 1985. It is described under waste site 132-B-1 in WIDS. 
Curie Estimates for Waste. Throughout its history, Project P-10-X was plagued with contamination releases to the environment and to personnel. The primary release mechanism was lost product itself, which simply escaped as a gas. Estimates of such tritium atmospheric releases vary from about 9,000 to $25,000 \mathrm{Ci}$ in one reference to the much larger number of 200,000 $\mathrm{Ci}$ released as gaseous tritium through 1954 (Heeb and Gydesen 1994). Material released in that form is no longer of concern today since it should be reduced to negligible levels through dispersion and decay. The second largest source of contamination emitted from Project P-10-X operations was the mercury used in the Toepler pumps and pressure gauges. It is estimated that hundreds of liters of contaminated mercury was disposed to the 108-B crib, with subsequent diffusion through surrounding soil and groundwater. Interestingly, no mercury contamination has ever been detected in 100-B Area groundwater; however, well coverage is very limited throughout the 100-B Area, and monitoring for mercury has been even more limited. Tritium contamination also was released via particles of broken glass and pieces of metal equipment, through the grease and oil that contacted process equipment, via liquid nitrogen that was used in the lost product reclamation mission and in the cold traps of the lines and leak detectors, and through the carbon tetrachloride and other decontaminating agents used to wash down equipment. Additionally, shipping casks used in Project P-10-X sometimes spread external contamination along travel routes and at the 105-B wash pad where they were monitored. Preliminary estimates made at the time ranged from 20,000 to $155,000 \mathrm{Ci}$ buried as solid waste, ostensibly in the 118-B-1 burial ground, although there is anecdotal information suggesting that some waste may have been disposed to undocumented trenches closer to the 108-B facility. Data presented by Heeb and Gydesen (1994), using information from old formerly classified lab notebooks that have since been destroyed, suggest a much larger number in the range of 400,000 to $500,000 \mathrm{Ci}$. Using the 500,000 $\mathrm{Ci}$ number as a conservative upper bound, the inventory of the 118 -B-1 burial ground translates to $1,780 \mathrm{Ci}$ in 2050 . That is a much higher number than given by Stenner et al. (1988) which calculates out to $102 \mathrm{Ci}$ after correction for decay to 2050.

Data from the operational time period showed that something on the order of 5 to $10 \%$ of the tritium produced by irradiation was retained in the lithium-aluminum targets. There is no information on the disposition of the lithium-aluminum alloy targets themselves, but it is reasonable to assume that they also went to the 118-B-1 burial ground, which received a large amount of radioactive metallic waste from reactor operations. That would account for on the order of 500,000 to 1,000,000 $\mathrm{Ci}$ of tritium sent to ground. It is unclear if that fraction was included in the estimates of buried waste discussed above since there seems to be some disagreement in the two estimates. To include that additional degree of uncertainty it would be reasonable to use a number of 3,000 $\mathrm{Ci}$ as a conservative estimate for the tritium content of the 118-B-1 burial ground as of 2050. However, it is also important to note that because of the nature of Project P-10-X, which produced a gaseous product from a metallic target, very little of the tritium included in the original inventory is likely to have been initially in a form readily available for exchange with groundwater. In particular, any residual tritium not released during extraction is unlikely to represent a readily available source of tritium as temperature release experiments have shown that such tritium is very tightly bound within the metal alloy matrix at ambient temperatures. Tritium (i.e., hydrogen) is, however, a notoriously labile element so it may eventually make its way over time into an environmentally available form as water (i.e., HTO). The Stenner et al. (1988) report also shows a small quantity of tritium disposed to the 118-B-6 burial ground, which was once referred to as the 108-B Solid Waste Burial Ground. That very small facility, which is located a short distance north of the reactor building, operated from 1950 to 1953 . After correction for decay to 2050, that inventory amounts to about $5 \mathrm{Ci}$. 
Historical records for Project $\mathrm{P}-10-\mathrm{X}$ release estimates for cribbed liquid tritium waste range from 2,500 to $6,000 \mathrm{Ci}$ in one historical reference, to on the order of 10,000 $\mathrm{Ci}$ calculated from information in the Heeb and Gydeson (1994) report. Using the larger number then, disposal to the 116-B-5 crib corrected for decay to 2050 thus comes to about $35 \mathrm{Ci}$, about an order of magnitude higher than the number given by Stenner et al. (1988) or that currently in the Environmental Release Summary (ERS) database.

Groundwater Contamination. Given that substantial tritium inventories have existed in at least three waste sites in the 100-B Area since 1950, it is worthwhile examining what is known about groundwater contamination in that part of the site. Figure D.1 shows the main features of the 100-B Area including wells and major engineered facilities. The 118-B-1 burial ground is shown at the southwest corner of the 100-B Area in Figure D.1. The 118-B-6 burial ground is not shown on the figure; it is located approximately 100 meters southeast of the 116-B-5 crib, which was also known as the 108-B crib. As can be seen from the map, well coverage is limited. The 100-B Area has long been known to be one of the most under-monitored areas of the Hanford Site. For example, the 118-B-1 burial ground, which is the likely repository of the solid tritium waste from Project P-10-X, has only one downgradient well, 199-B8-6, installed relatively recently. Monitoring of that well for tritium began in July 1992 with a moderately low measurement of $6,300 \mathrm{pCi} / \mathrm{L}$ recorded. Tritium levels remained relatively low through the mid $1990 \mathrm{~s}$ then suddenly shot up to a high of $91,900 \mathrm{pCi} / \mathrm{L}$ in January 1998 . Subsequent to that, monitoring has only been performed on an annual basis with a generally decreasing trend in evidence. The reading taken in January of 2002 was $26,700 \mathrm{pCi} / \mathrm{L}$, and it was essentially unchanged in January 2005 when last sampled. There is, thus, clear evidence for some tritium contamination in the area.

Well 699-65-83, located just upgradient of the burial ground, shows no indication of tritium contamination extending back to 1971 suggesting strongly that the 118-B-1 burial ground itself is the likely source of a local tritium plume moving downgradient from that location. Unfortunately, the scarcity of wells in the area and lack of good trend information makes it impossible to say more. A similar situation exists for the 116-B-5 crib with only one or two wells in potentially useful locations. Well 199-B4-1, located at one end of the crib, shows two broad pulses of tritium in the late 1970s and mid 1980s with a maximum of 130,000 pCi/L reached in December 1984. The well was monitored in April 1999 with the tritium level down to only $4,920 \mathrm{pCi} / \mathrm{L}$. When monitored in 2004 , the well showed a $6,100 \mathrm{pCi} / \mathrm{L}$ tritium concentration. Well 199-B5-2 is located approximately downgradient of the crib about 300 meters away. It has only been in use since mid-1992. It shows a broad tritium pulse ranging up to $420,000 \mathrm{pCi} / \mathrm{L}$ in early 1997 with levels declining to relatively low levels by the end of 2000. In fiscal year (FY) 2005, tritium increased sharply to $161,000 \mathrm{pCi} / \mathrm{L}$ in well 199-B5-2 after several years of gradual increase since 2000. The situation is even less satisfactory for mercury monitoring. Well 199-B8-6 was monitored intensively for mercury during 1992 to 1995 with none detected. A similar situation is seen in essentially all of the 100-B Area wells with almost all of the measurements conducted in that same time period. There are currently no mercury measurements being made in the 100-B Area groundwater. 


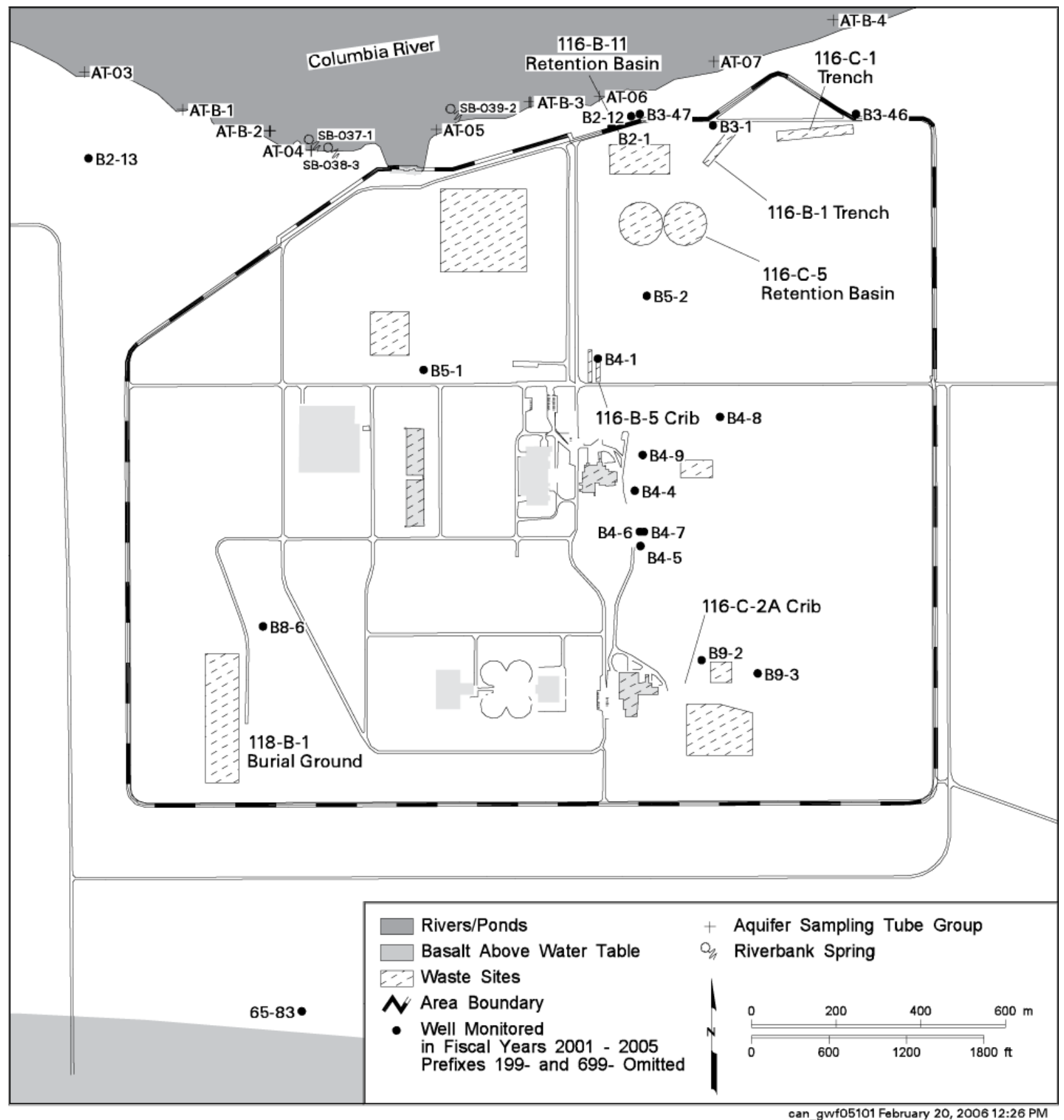

Figure D.1. Well Coverage Map for 100-B Area 


\section{D.3 Hanford Coproduct Program (1963-1967)}

History. In the mid-1960s, a project known as the Hanford Coproduct Program was undertaken. Unlike earlier tritium production activities performed at Hanford and Savannah River, the tritium end product was intended for use in energy production by controlled fusion of deuterium-tritium mixtures rather than for weapons applications. However, because of the obvious overlap with weapons-related work, all research activities were classified at that time. Information associated with that work was partially declassified in the early 1970s with technical details relevant to Savannah River tritium production applications remaining as classified. In its early stages, which began in 1963, the program was intended to provide comprehensive engineering data on the optimal characteristics of lithium-based irradiation targets to be used for tritium production in parallel with both plutonium and electrical energy production at the Hanford N Reactor. This work is documented in several unclassified reports. A good summary of the activities performed can be found in Johnson et al. (1976).

Initial irradiations for the Coproduct Program were performed in one of the K Reactors using lithiumaluminum rods similar to those used in the earlier Project P-10-X. All subsequent Coproduct irradiations were performed at $\mathrm{N}$ Reactor during 1965 to 1967 culminating with a full scale test involving more than 1500 lithium aluminate target columns containing on the order of 17 tons of lithium aluminate. Tritium production associated with that final test was calculated to be on the order of 60 million curies of tritium per year. Following irradiation, the entire target load was shipped to Savannah River for extraction, so it is unlikely that the production run itself was responsible for significant tritium releases at Hanford other than those associated with $\mathrm{N}$ Reactor cooling water; however, research activities involving smaller but still significant quantities of tritium production are almost certain to have generated some major waste products. As part of the research program, several different materials were investigated for suitability as targets including lithium-aluminum alloy, numerous lithium containing salts, lithium oxide, lithium metatitanate, lithium silicate, lithium loaded glass, petalite, and lithium aluminate. Ultimately, lithium aluminate, a highly refractory ceramic, was chosen as the most stable form and all subsequent work involving tritium production, including the current DOE plans for tritium production using Tennessee Valley Authority (TVA) reactors (Watts Bar and Sequoyah), employs that material. Several irradiations were performed in support of the Coproduct work and only some of the targets were fully extracted for tritium. In some cases the test targets were simply visually inspected or subjected to examination by drilling to determine the amount of gas pressure buildup. All research activities including tritium extractions in support of the Coproduct Program were performed in the Hanford 300 Area with the Post Irradiation Test Facility in the 327 Building acting as the hub of the operation. A number of different forms were used for irradiation of targets particularly during the early work aimed at determining approximate yields. The predominant target form used for the later work consisted of zircaloy- 2 canned columns, 3.175 centimeters ( 1.250 inches) outside-diameter by 60.96 centimeters ( 24 inches) long with either 0.0762 - or 0.2413 - centimeters $(0.030$ - or 0.095 -inch) -thick walls. Each contained two aluminumclad ceramic cores. The lithium used in these targets was either slightly depleted in lithium-6 (3.68\%), close to naturally abundant (6.07\%), or slightly enriched (12.26\%) unlike the highly lithium-6 enriched targets used in the deuterium moderated Savannah River reactors for weapons production of large quantities of tritium.

The fate of any waste generated by the Coproduct Program research activities, including the extracted tritium itself, remains unknown. Record keeping during that time period was at best limited, and many of the disposal records from that time period have been destroyed during several past space-saving records 
purges. In addition, the fact that work was performed under conditions of strict classification further complicates the situation. It is, thus, possible that some record of material accountability has yet to be declassified; however, that is unlikely since researchers investigating the plutonium inventory of the burial ground have already concluded that even the safeguards related special nuclear materials records from that period have been destroyed; so, it is probable that tritium target disposal records suffered a similar fate.

Consistent with that conclusion is the fact that the rather extensive records searches performed to date on several different occasions including very recently have yielded little of value. References to lithiumaluminum were found in materials transfer Radioactive Shipment Record (RSR) records from the 327 Building starting to appear in the 1965 time frame. Unfortunately these log entries showed no indication of the final disposition of the material. The RSRs typically showed dose rates associated with the lithium-aluminum materials in the range of 100 to $200 \mathrm{mr} / \mathrm{hr}$. That seems reasonable for materials that have been exposed to a significant reactor flux but contain no components likely to produce an unusually large inventory of neutron activation products. The lithium aluminate itself would have produced external dose only through activation of impurities while isotopes of zirconium in the zircaloy- 2 cladding have relatively low neutron capture cross-sections with 65 day zirconium- $95 /$ niobium-95 as the only long-lived activation products of consequence. Impurities or minor alloy components in the zircaloy-2 including chromium, iron, niobium, and tin would also have contributed some dose most of which is long-since decayed by now. The log entries refer to the material as lithium-aluminum or lithium-aluminum columns. It appears that this was a generic term used for lithium targets most of which were actually lithium aluminate packaged as described above.

Since the Coproduct work was performed during the time period for which the 618-11 burial ground was used as the primary site for disposal of 300 Area operations waste it is quite reasonable to suppose that some, if not all, of the Coproduct Program research waste was routed to that location. The limited records associated with the 618-11 burial ground operation do, in fact, list "aluminum-lithium" as having been disposed to the burial ground. While lithium aluminate and other related materials are not specifically enumerated separately, it is unlikely that the difference in terminology is significant as discussed above. For lack of additional details, it would be prudent to assume that the term is used as a generic reference to tritium production target materials. Hydrogen gas is also included on the same list. Since it seems highly unlikely that actual high-pressure cylinders of hydrogen would be placed in a burial ground intended for low-level radioactive waste, it is possible that this is an oblique reference to gaseous tritium waste associated with the target extractions. Tritium is a very labile material with the ability to eventually diffuse through most materials and reactively exchange with normal hydrogen in water and some organics. Unless specifically packaged for long-term storage, it is quite likely that tritium-containing materials disposed to a burial ground would pose an eventual threat for groundwater contamination.

While there is clearly a high degree of likelihood that groundwater contamination recently observed near the 618-11 burial ground is in some way associated with Coproduct waste, further defining the nature and location of the waste through record searches may prove impractical. At this point, the most likely candidate for a source location appears to be a group of three caissons located near the north-central portion of the burial ground. The physical dimensions of the targets were small enough that they would have easily fit into the angled 3-foot-diameter caisson entry tubes. However, in view of the fact that the targets had relatively low external dose rates, it is also possible that they may have been disposed to the trenches in the same general area. Release of tritium is certainly easier to understand if the materials were completely uncontained in trenches. In that case, irrigation of the burial ground during the stabilization 
and re-vegetation work conducted in June 1982 may have been responsible for mobilizing tritium into the groundwater system beneath the trenches. It does appear unlikely that the drum storage units on the northeastern side of the burial ground are responsible for the largest helium-3 concentrations observed in the soil-gas survey simply because of their locations; however, at this time multiple sources cannot be ruled out. There is likely to have been multiple waste disposal events over the two year period of the main Coproduct Program activities, and those materials may well have gone to different locations within the burial ground.

Helium-3 Survey. In an attempt to provide better answers for those questions, a helium-3-based soil-gas survey was conducted on the periphery of the burial ground by Pacific Northwest National Laboratory (PNNL) starting in August 2000. Helium-3 is the stable decay product of tritium. Determination of the extent of elevated helium-3 levels in soil gas can provide a measure of the location of tritium contamination in the vadose zone or groundwater. Results of that study have been documented by Olsen et al. (2001) as well as more recently in Olsen et al. (2006). Briefly, the survey showed a strong source of tritium consistent with the area of the caissons; however, because the study was confined to the area outside the fence, it was inconclusive with respect to actual location of the source or for providing an estimate of source strength.

Curie Estimates for Waste. Curie estimation for the 618-11 burial ground is fraught with considerable uncertainty. It is clear that all materials irradiated at N Reactor under the NR-75 and NR-87 tests were sent to Savannah River and, thus, have no potential impact at Hanford. Materials associated with the two earlier tests, NR-8 and NR-57, are quite likely to have contributed to the tritium inventory of the 618-11 burial ground. The disposition of the 48 columns of lithium aluminate irradiated under NR-66 remains unclear, however. It appears likely that they were added to the much larger number of columns (1400 to 1500) used in the later tests and also sent to Savannah River. Of the materials used in NR-57, it appears that 37 of the 66 canned targets contained in the two columns were also sent to Savannah River for engineering tests. Therefore, the remaining 29 were retained for tests at Hanford. The length of the irradiation was not documented in the report either, so for the purpose of estimation it is assumed to be the same as NR-66, i.e., six months at $4000 \mathrm{MW}$. Using the reported average values for retention of tritium after extraction, an approximate inventory for disposal can be estimated to be around 2,200 $\mathrm{Ci}$ in 2000 or $133 \mathrm{Ci}$ in 2050. The estimated Curie content of the groundwater plume in 2001 according to Lindberg and Dresel (2002) is 190-225 Ci, which would be about $10 \%$ of the estimated source which seems reasonable for the purposes of initial estimation.

Groundwater Contamination. Interest in the 618-11 burial ground as a source of major tritium inventory became particularly acute following the discovery in January 1999 of very high levels of tritium in groundwater downgradient of the burial ground. Well 699-13-3A showed 1.86 million $\mathrm{pCi} / \mathrm{L}$ when first monitored in January of 1999. Within a year, that level had increased to 8.14 million $\mathrm{pCi} / \mathrm{L}$, an exceptionally high value for Hanford, particularly considering the remote location on the site. Since that time, the plume has generally shown a decreasing trend at well 699-13-3A. The measurement taken, in January 2003, showed 3.6 million pCi/L. Levels in 2004 were in the 1.9 to 2.2 million pCi/L range. A full discussion of the extent of the original groundwater plume and the associated hydrologic controls can be found in Section 2.12.7.2 (Lindberg and Dresel 2002, pages 2.310-2.312). Current monitoring results can be found in Section 2.12.1.5 in the discussion of Operable Unit 300-FF-5 in the report Hanford Site Groundwater Monitoring for Fiscal Year 2004 (Hartman et al. 2005). Tritium contamination is clearly associated with the 618-11 burial ground with the most likely source being residues from the tritium targets used in the Coproduct Program. As part of the 618-11 investigation some depth discrete samples 
of groundwater were collected which provide a basis for estimation of the plume thickness. Using that and other information from the investigation, Lindberg and Dresel (2002) have estimated the groundwater plume inventory of tritium to be between 190 and $225 \mathrm{Ci}$ at that location, which translates to about $14 \mathrm{Ci}$ in 2050 assuming minimal movement.

\section{D.4 References}

Hartman MJ, LF Morasch, and WD Webber (eds.). 2005. Hanford Site Groundwater Monitoring for Fiscal Year 2004. PNNL 15070, Pacific Northwest National Laboratory, Richland, Washington.

Heeb CM and SP Gydesen. 1994. Sources of Secondary Releases from Hanford Operations. Section 7.0, PNWD-2254 HEDR, UC-000, Pacific Northwest National Laboratory, Richland, Washington.

Johnson AB, Jr., TJ Kabele, and WE Gurwell. 1976. Tritium Production from Ceramic Targets: A Summary of the Hanford Coproduct Program. BNWL-2097, UC-20, Pacific Northwest National Laboratory, Richland, Washington.

Lindberg JW and PE Dresel. 2002. "300 Area" in Hanford Site Groundwater Monitoring for Fiscal Year 2001, MJ Hartman, LF Morasch, and WD Webber (eds.). PNNL 13788, Pacific Northwest National Laboratory, Richland, Washington.

Olsen KB, PE Dresel, and JC Evans. 2001. Measurement of Helium-3/Helium-4 ratios in Soil Gas at the 618-11 Burial Ground. PNNL-13675, Pacific Northwest National Laboratory, Richland, Washington.

Olsen KB, PE Dresel, JC Evans, WJ McMahon, and R Poreda. 2006, in press. "Measurement of Helium Isotopes in Soil Gas as an Indicator of tritium Groundwater Contamination.” Env. Sci. and Tech.

Stenner RD, KH Cramer, KA Higley, SJ Jette, DA Lamar, TJ McLaughlin, DR Sherwood, and NC Van Houten. 1988. Hazard Ranking System Evaluation of CERCLA Inactive Waste Sites at Hanford. PNL-6456, UC-70, Pacific Northwest National Laboratory, Richland, Washington. 


\section{Appendix E}

Best Estimate Inventory - Cumulative in 2005 


\section{Appendix E}

\section{Best Estimate Inventory - Cumulative in 2005}

This appendix presents the best-estimate inventory on December 31, 2005. The inventory input to the simulation is a waste site/year/analyte data file and is quite large because simulations can involve up to 690 waste sites, over 50 years of nuclear materials operations, and up to 14 analytes. The cumulative and decay corrected inventory discharged and disposed by a given date, in this case December 31, 2005, is more readily displayed. When acquiring inventory data and estimates, one often finds or is provided a best-estimate value without regard to its uncertainty distribution. In the case of the stochastic Hanford Soil Inventory Model (SIM) results, the best estimate is the mean. However, in all other cases the single value found or provided is simply interpreted as the best-estimate. The inventory compilation shown here is the best-estimate value for each waste site and analyte. This inventory was taken from the 'By_Site_2005' tab of the 'Tables_Best_2005_11_17_Inv-Data-Package.xls' file.

The best-estimate inventory shown here is a post-processed file that derives from the waste site/year/ analyte file used to drive the Hanford assessment simulation. The waste site /year/analyte file is created by the INVENTORY code when it applies the uncertainty rules described in Section 6 to the 'disposal action file' of 'daf' created by INPROC. The INPROC code applies the fill-in and surrogate rules described in Section 4 to the inventory data files described in Section 5. The input file for INPROC execution is 'inproc-input_2005-11-09_DCR-0024.csv' and it is under configuration management and maintained on the SAC Windows File server at $\backslash$ sac.pnl.gov\shareldata $\backslash$ rev.1 $\backslash$ inventory $\backslash$ The 'Tables_Best...' and the 'inproc-input...' files are attached as an electronic appendix. In addition the output of the INPROC code for reference case A, (i.e., CA_Ref_A.daf), which is the basis for the best-estimate tables, is also included in the electronic appendix.

The background for table entries has been color coded to indicate the type or source of the data; Hanford SIM result, Hanford Tank Waste Operation Simulator (HTWOS) model result, record, estimated by fill-in rule, and estimated by a surrogate rule, or some combination. A key is provided at the bottom of the table.

While assembling the inventory, every effort was made to be consistent with inventories used in performance assessments being prepared for the single-shell tanks and the integrated disposal facility. Near perfect consistency was achieved by using the same simulation by the HTWOS model (Kirkbride et al. 2005). However, Kirkbride et al. (2005) shows a radium-226 inventory in tank 241-C-106 of 416 curies, decay correct to January 1, 2004. Tank 241-C-106 has been cleaned out and the HTWOS model simply used the Best Basis Inventory (BBI) for this tank as its residual. However, the BBI inventory for radium-226 was in error and has been updated to $1.39 \mathrm{E}-03 \mathrm{Ci}$, and that value is now in the draft performance assessment supporting the closure of single-shell tanks. This inconsistency was discovered during peer review of this document, and the updated value has not been promulgated into this inventory for use in Hanford assessments.

Kirkbride RA, PJ Certa, TM Hohl, AM Johnson, and RS Wittman. 2005. Hanford Tank Waste Operations Simulator Model Data Package for the Development Run for the Refined Target Case. RPP-RPT-23412, Revision 0A, CH2M HILL Hanford Group, Inc., Richland, Washington. 
Inventory by site for waste form "All_Types" at the year 2005

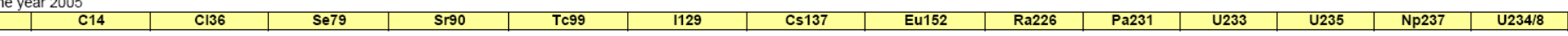

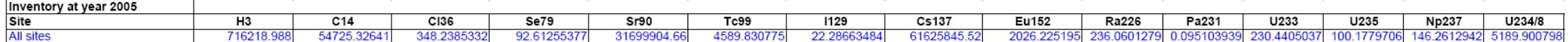

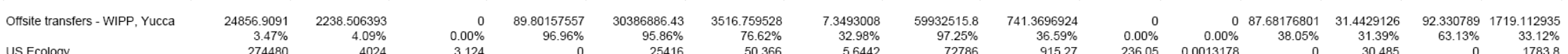

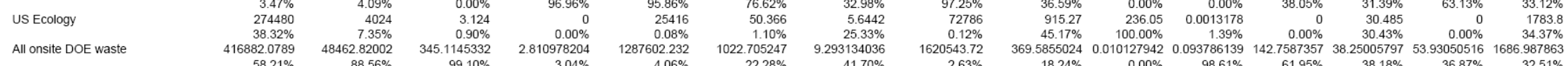

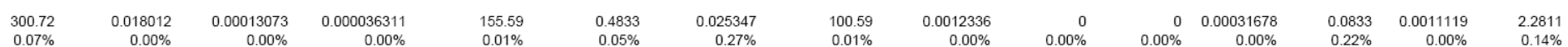

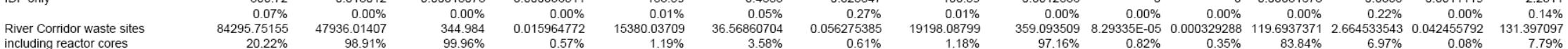

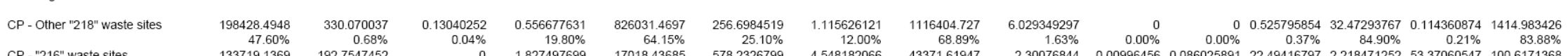

CP - "216" waste sites

$\mathrm{CP}$ - facilities

CP - "200" waste sites

CP - UPR waste sites

CP - tank "241" waste sites

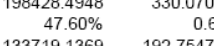

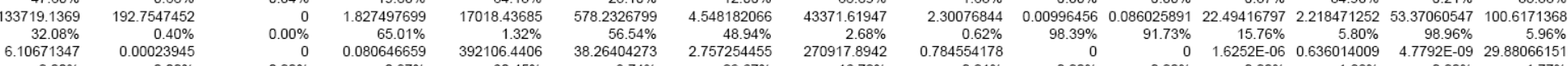

$6.10671347 \quad 0.00023945$

\begin{tabular}{rr}
$0.00 \%$ & $0.00 \%$ \\
\hline 85771668 & 0.053940232 \\
$0.00 \%$ & $0.00 \%$
\end{tabular}

0008064665

$\begin{array}{rrrrrrrr}2.68 \% & 0.62 \% & 98.39 \% & 91.73 \% & 15.76 \% & 5.80 \% & 98.96 \% & 5.96 \% \\ 270917.8942 & 0.784554178 & 0 & 0 & 1.6252 \mathrm{E}-06 & 0.636014009 & 4.7792 \mathrm{E}-09 & 29.88066151\end{array}$

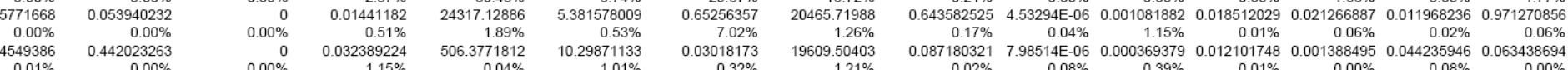

$0.01 \%$
0.442023263
$0.00 \%$

$\begin{array}{lllllllll}19609.50403 & 0.087180321 & 7.98514 E-06 & 0.000369379 & 0.012101748 & 0.001388495 & 0.044235946 & 0.063438694\end{array}$

i Subtotal onsite DOE waste \begin{tabular}{rrrrr}
416882.0789 & 48462.82002 & $0.00 \%$ & $10.08 \%$ & $0.94 \%$ \\
\hline
\end{tabular}

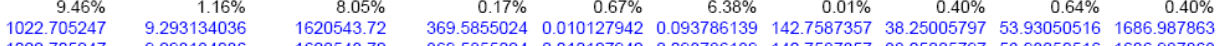

\begin{tabular}{|c|c|c|c|c|c|c|c|c|c|c|c|c|c|c|c|}
\hline & & & & & & & & & & & & & 列 & & \\
\hline \multirow{4}{*}{\begin{tabular}{|l|} 
Analyte \\
SIM Data \\
HTWOS Data
\end{tabular}} & $\mathrm{H}_{3}$ & & Cl36 & Se79 & Sr90 & TC99 & 1129 & \begin{tabular}{l|l} 
Cs137 \\
\end{tabular} & \begin{tabular}{|l|l|} 
Eu152 \\
\end{tabular} & Ra226 & Pa231 & U233 & U235 & Np237 & U234/8 \\
\hline & 133702.8 & 197.0652 & & 2.147925 & 45658.41 & 686.9426 & 4.725024 & 198315.8 & 3.615051 & 0.01012271 & 10.09270421 & 140.8692 & 3.09736 & 53.80626 & 142.4063 \\
\hline & $18.67 \%$ & $0.36 \%$ & $0.00 \%$ & $2.32 \%$ & $0.14 \%$ & $14.97 \%$ & $21.20 \%$ & $0.32 \%$ & $0.18 \%$ & $0.00 \%$ & $97.48 \%$ & $6 \quad 61.13 \%$ & $3.09 \%$ & $36.79 \%$ & $2.74 \%$ \\
\hline & 6.10656 & 0.000239452 & & & 1.49896E-05 & 7.91107E-07 & $1.44951 \mathrm{E}-07$ & 2.23395E-06 & 9.84116E-06 & & & 1.62525E-06 & $5.68018 \mathrm{E}-0$ & $8 \quad 4.77922 \mathrm{E}-0 \mathrm{~S}$ & $2.62174 \mathrm{E}-06$ \\
\hline \multirow{2}{*}{ Record Data } & $\begin{array}{r}0.00 \% \\
581455.9\end{array}$ & 54455 & $\begin{array}{r}0.00 \% \\
348.2397\end{array}$ & $\begin{array}{r}0.00 \% \\
89.81289\end{array}$ & $\begin{array}{r}0.00 \% \\
31557320\end{array}$ & $\begin{array}{r}0.00 \% \\
3875.158\end{array}$ & $\begin{array}{r}0.00 \% \\
16.96564\end{array}$ & $\begin{array}{r}0.00 \% \\
6124640\end{array}$ & $\begin{array}{r}0.00 \% \\
1828.838\end{array}$ & $\begin{array}{r}0.00 \% \\
236.0519\end{array}$ & $\begin{array}{rr}\% & 0.00 \% \\
9 & 0.00137800\end{array}$ & $\begin{array}{r}0.00 \% \\
88.20773\end{array}$ & $\begin{array}{r}0.00 \% \\
96.15298\end{array}$ & $\begin{array}{r}0.00 \% \\
92.472\end{array}$ & $\begin{array}{r}0.00 \% \\
5035.24\end{array}$ \\
\hline & $81.18 \%$ & & $100.00 \%$ & & & & & & & $100.00 \%$ & & $38.28 \%$ & & $\begin{array}{l}92.4421 \% \\
63.21 \%\end{array}$ & \\
\hline \multirow[t]{3}{*}{ Estimated Data } & & 30.97 & & 0.643 & & 23.7 & 0.5872245 & & & & & & & & 1.28093 \\
\hline & $\% \%$ & & $0.00 \%$ & & 0.2 & $0.52 \%$ & $2.63 \%$ & & $1.77 \%$ & & & & $0.67 \%$ & & \\
\hline & $\begin{array}{r}1053.871 \\
015 \%\end{array}$ & $\begin{array}{l}41.28144 \\
0.08 \%\end{array}$ & $\begin{array}{r}0 \\
0.00 \%\end{array}$ & 0.007763802 & $\begin{array}{r}9022.727 \\
0.03 \%\end{array}$ & $\begin{array}{r}3.911258 \\
0.09 \%\end{array}$ & $\begin{array}{r}0.008751164 \\
0.04 \%\end{array}$ & $\begin{array}{r}11358.43 \\
0.0 \%\end{array}$ & $\begin{array}{r}157.9404 \\
777 \% \%\end{array}$ & $\begin{array}{r}5.26066 \mathrm{E}-06 \\
0.00 \%\end{array}$ & $\begin{array}{ll}6 & 0.001081374\end{array}$ & & $\begin{array}{l}0.2602630^{\circ} \\
0.060^{\circ}\end{array}$ & 08197827 & $\begin{array}{l}12.27392 \mathrm{r} \\
0.24 \%\end{array}$ \\
\hline & $0.15 \%$ & $0.08 \%$ & $0.00 \%$ & $0.01 \%$ & $0.03 \%$ & $0.09 \%$ & $0.04 \%$ & $0.02 \%$ & $7.79 \%$ & $0.00 \%$ & $1.14 \%$ & $0.59 \%$ & $0.26 \%$ & $0.01 \%$ & $0.24 \%$ \\
\hline
\end{tabular}

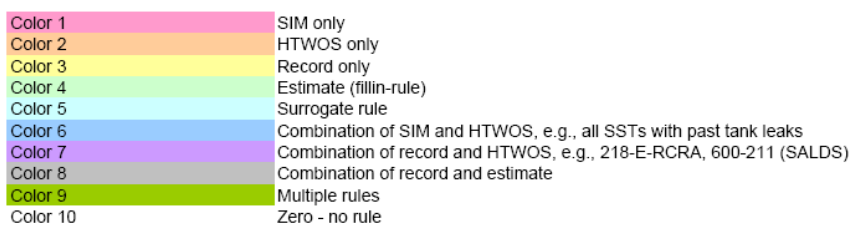


Inventory by site for waste form "All, Types" at the year 2005

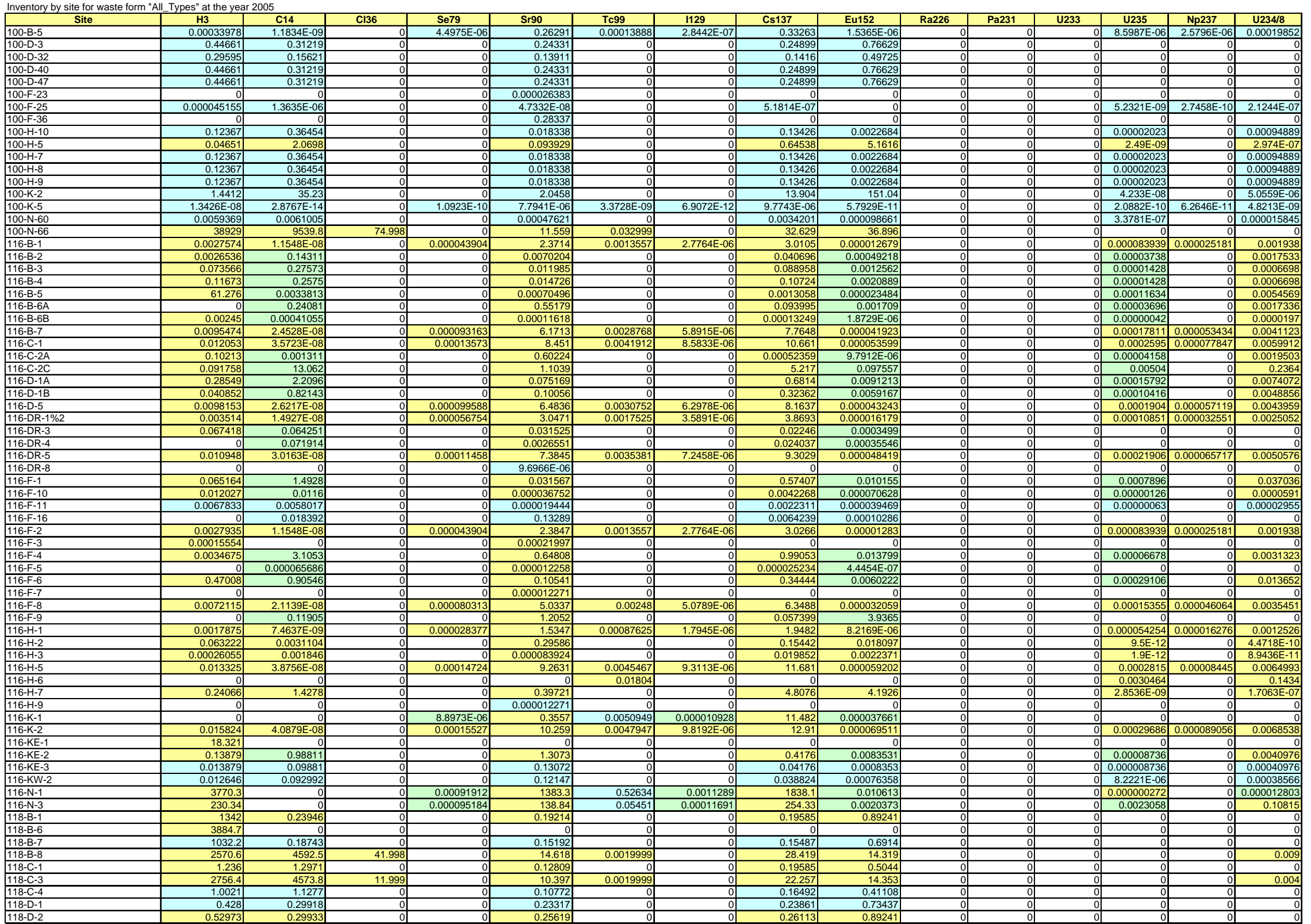




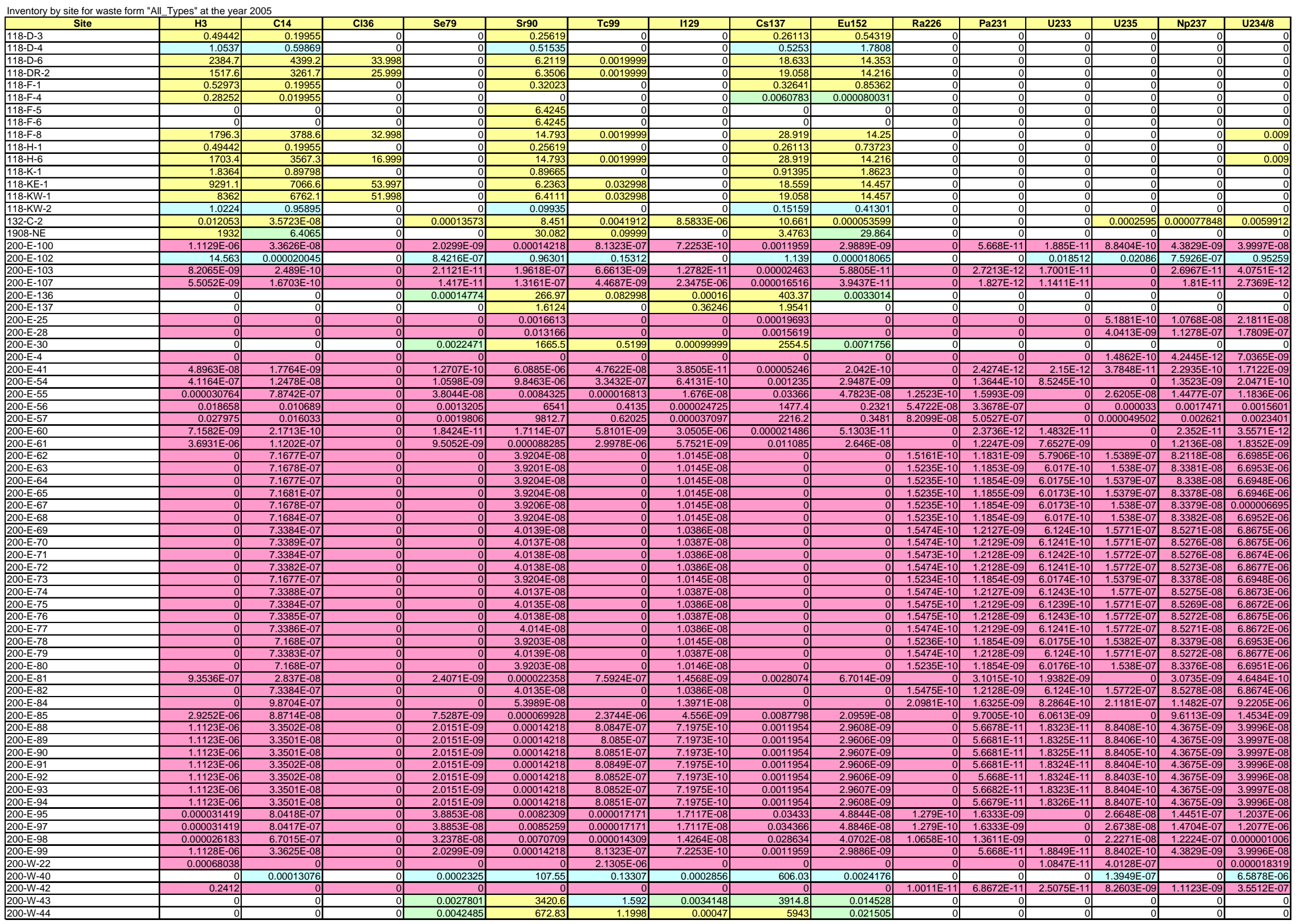




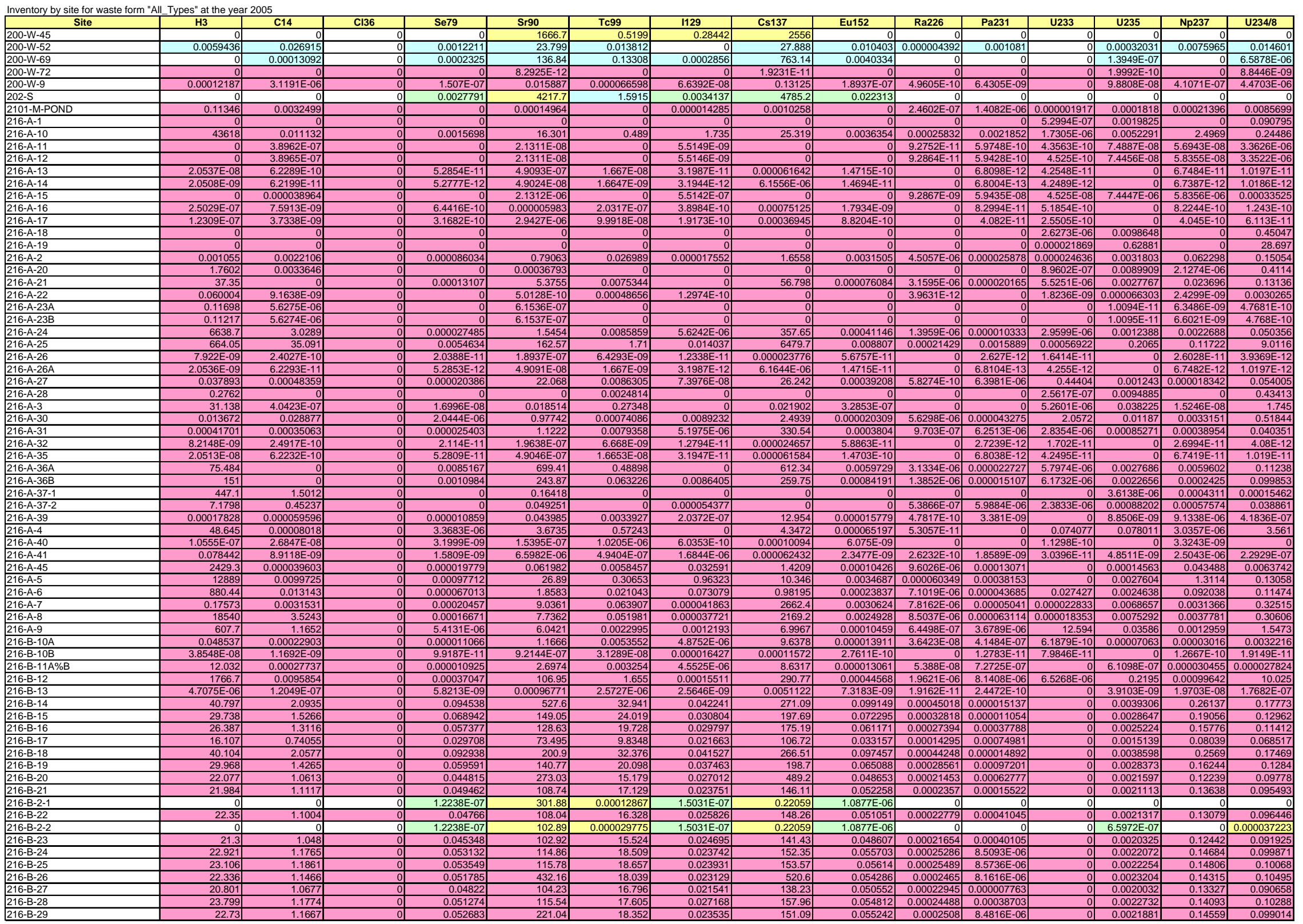




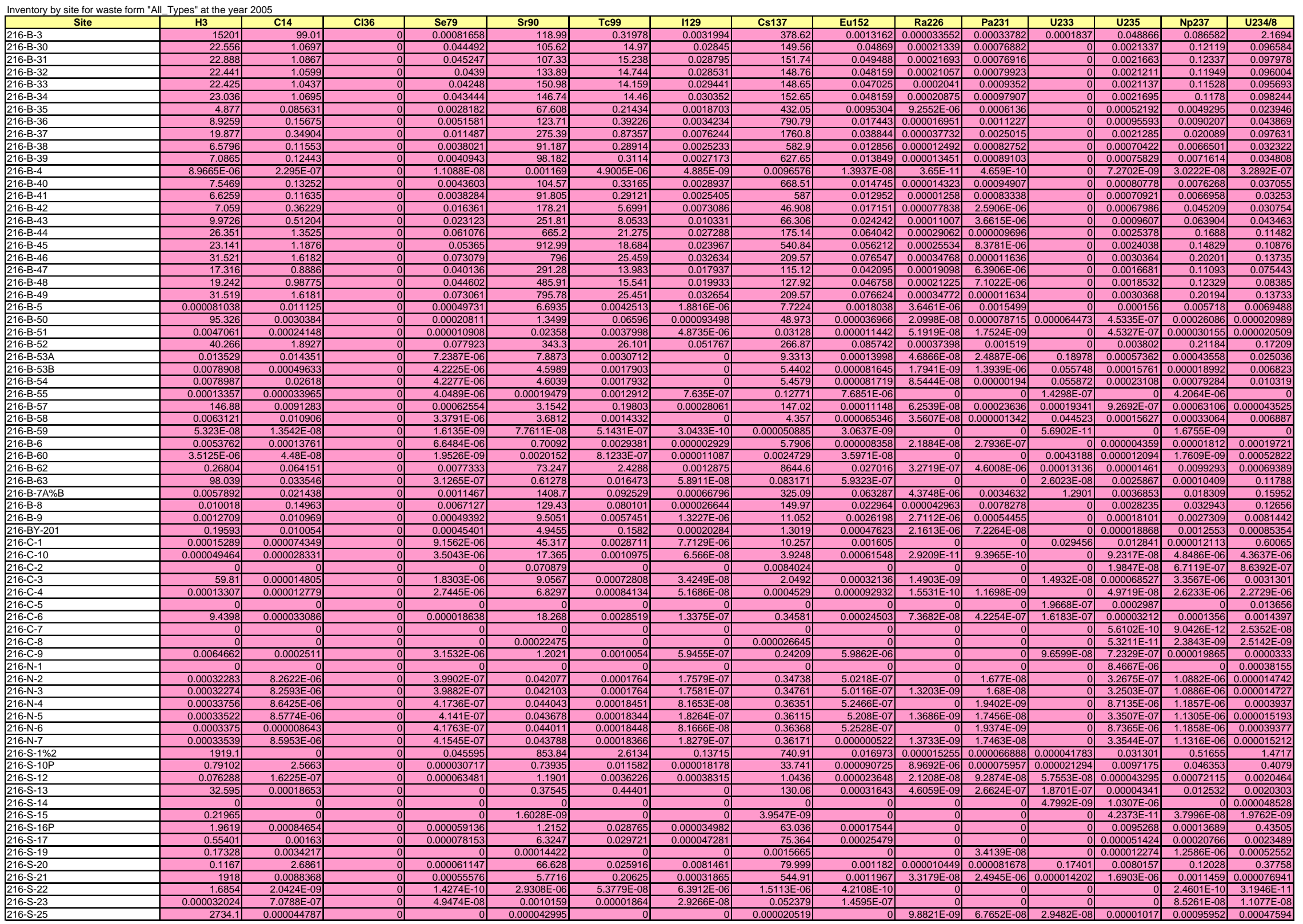




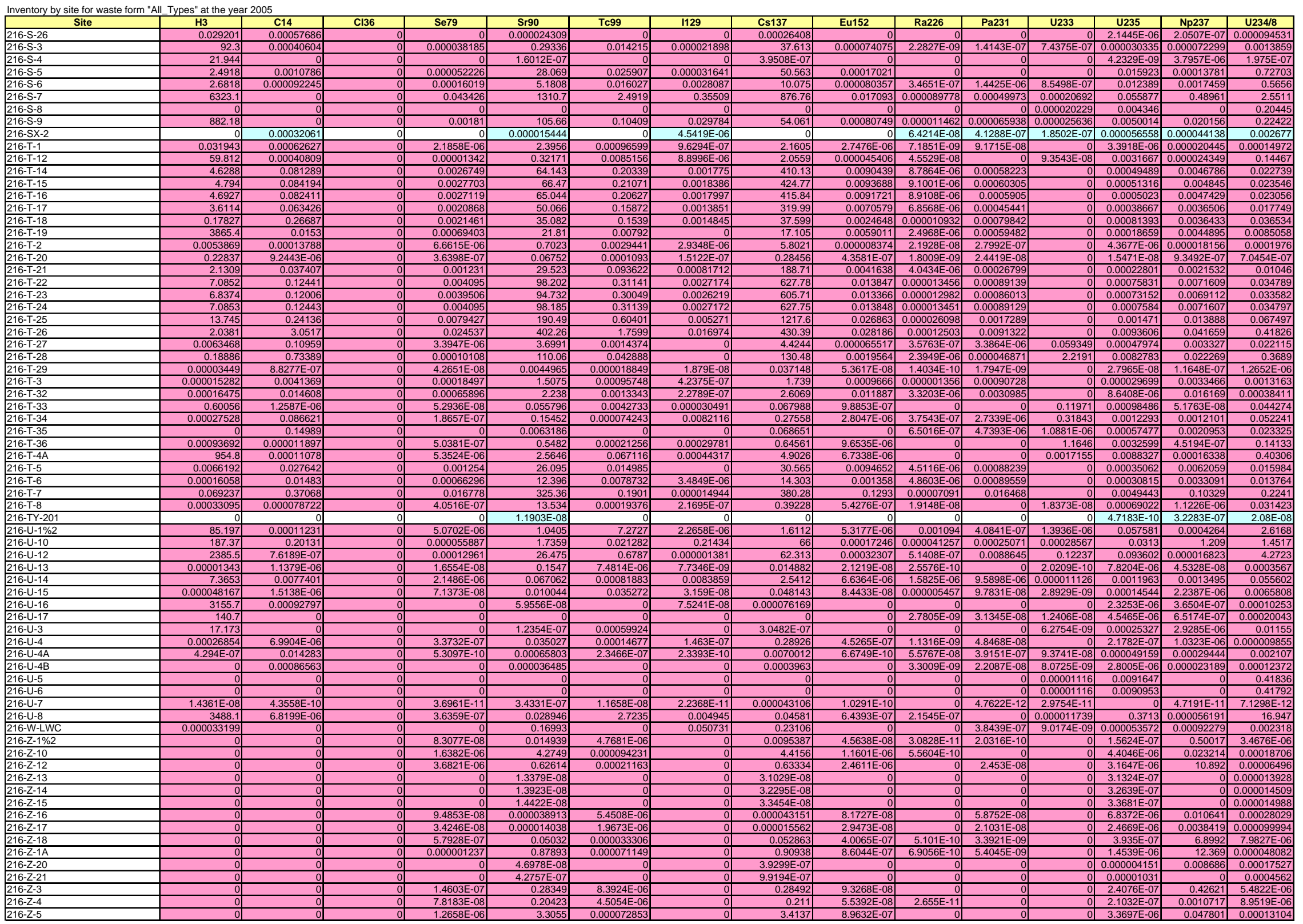


Inventory by site for waste form "All Types" at the year 2005

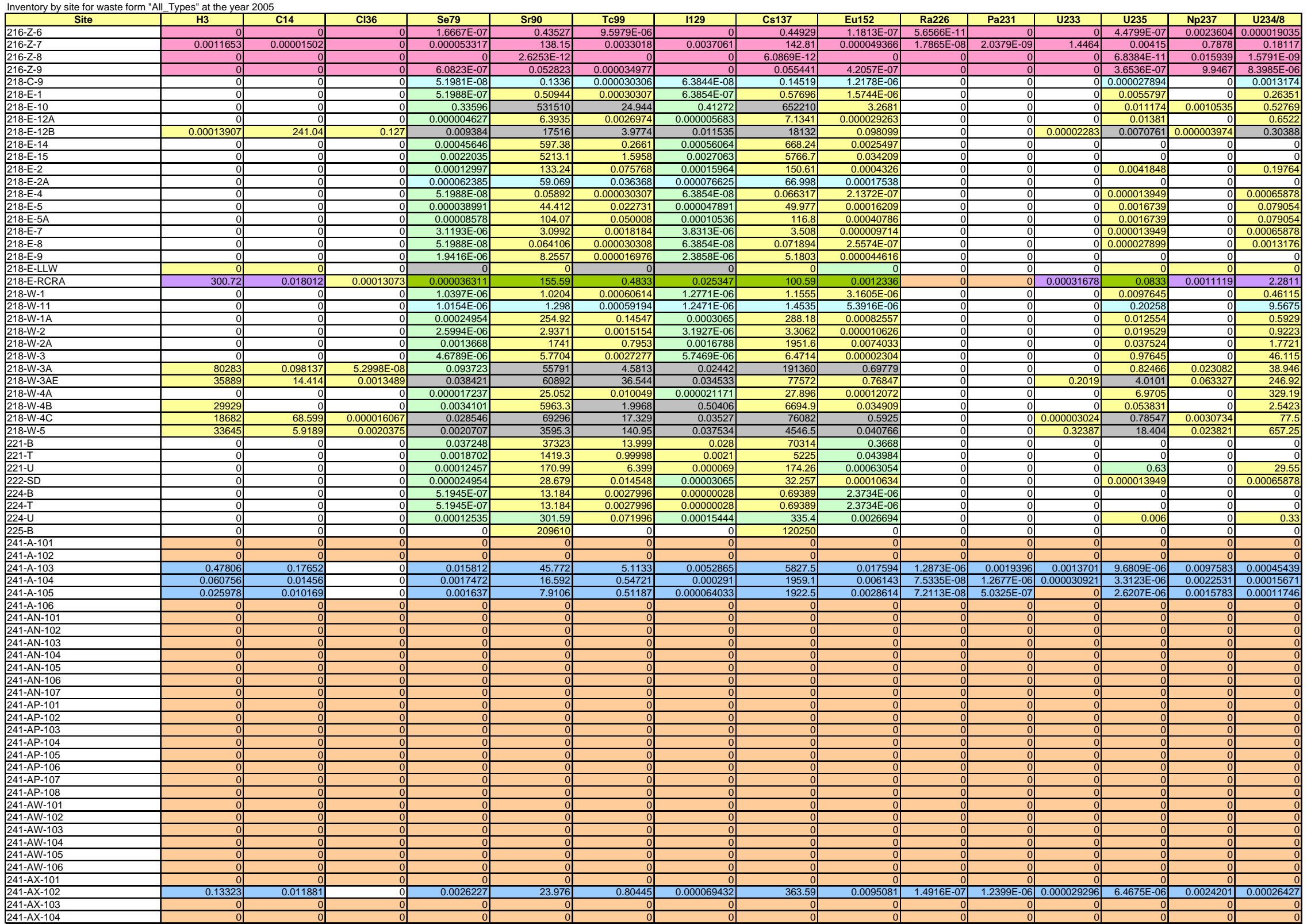




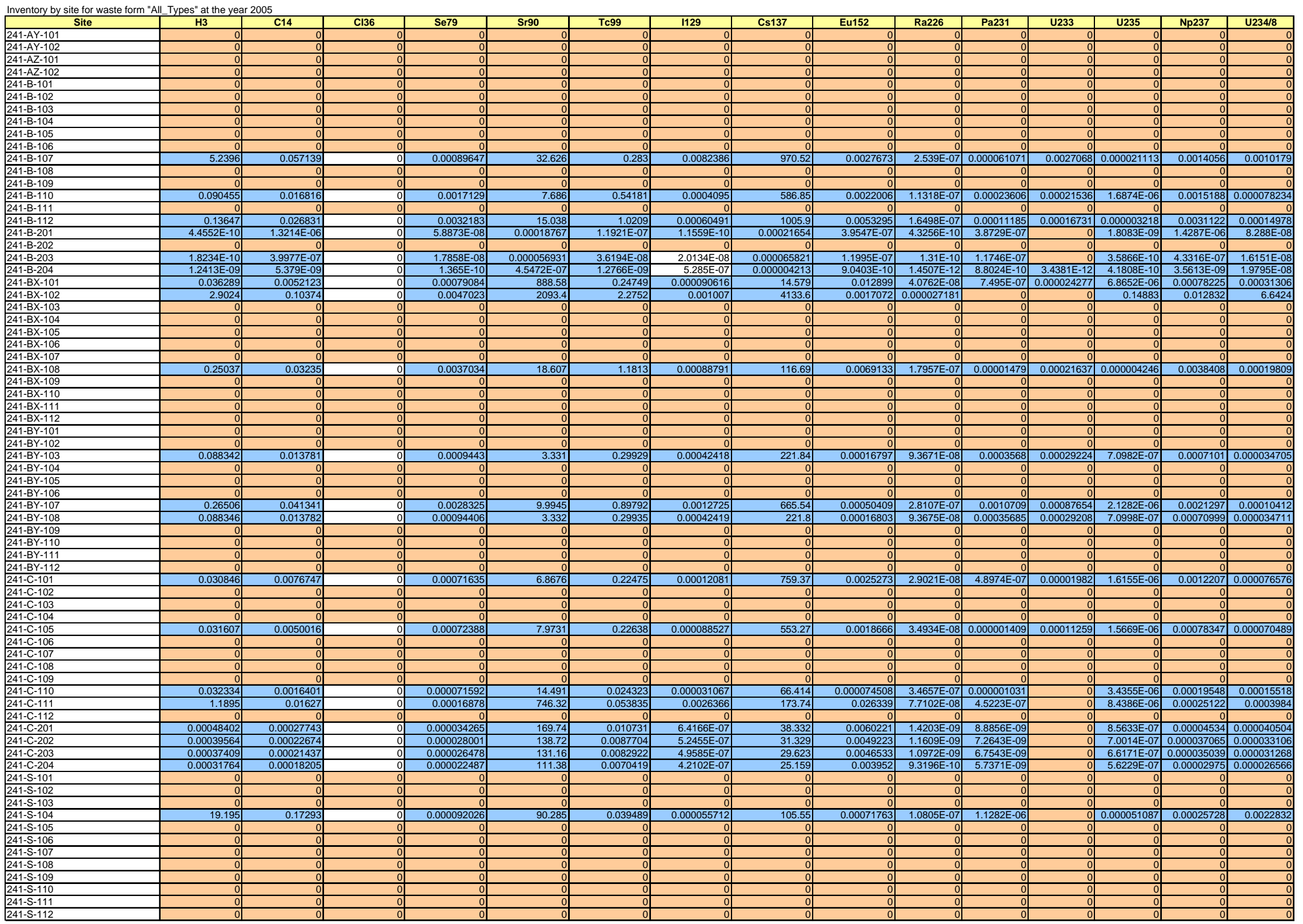




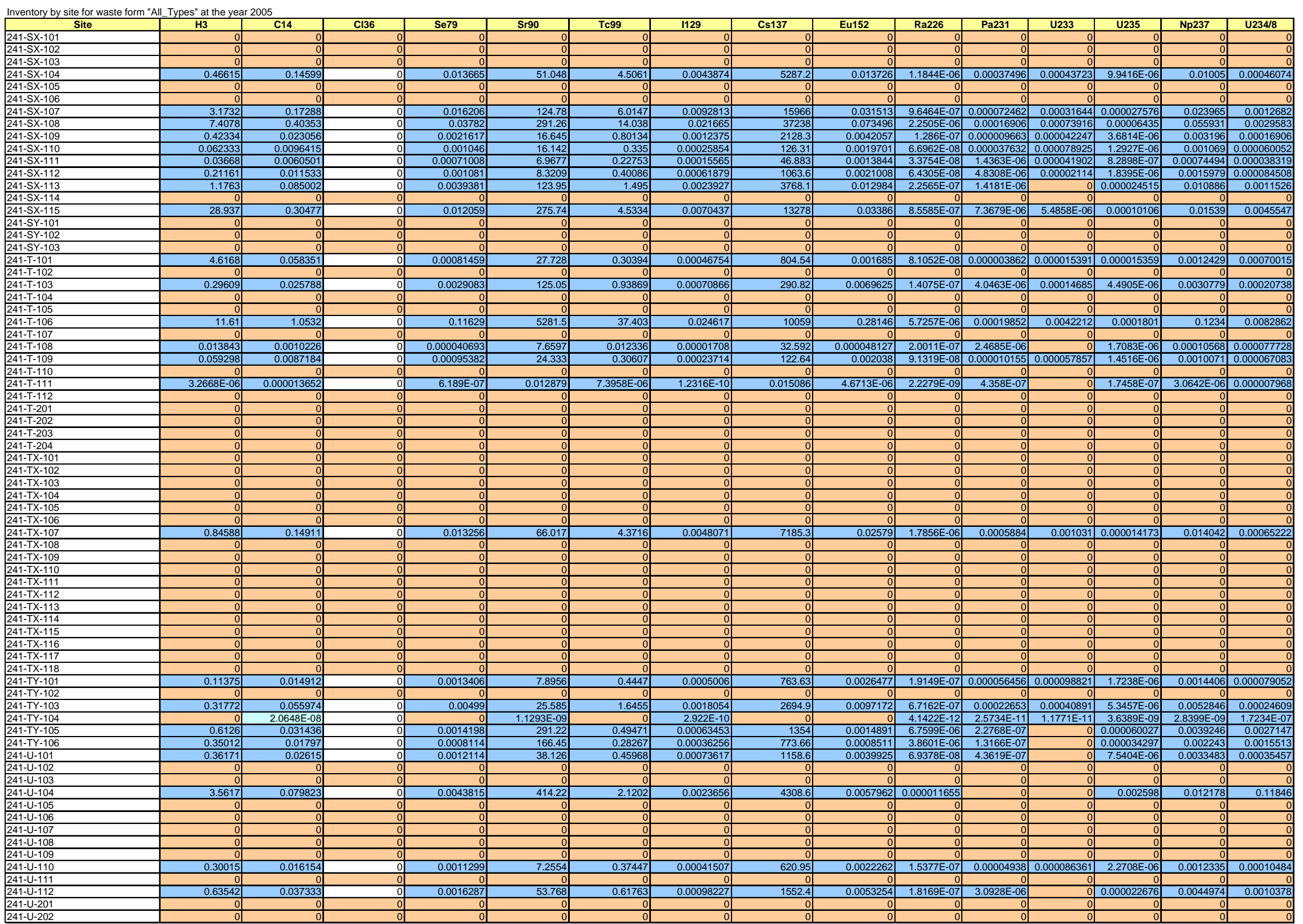




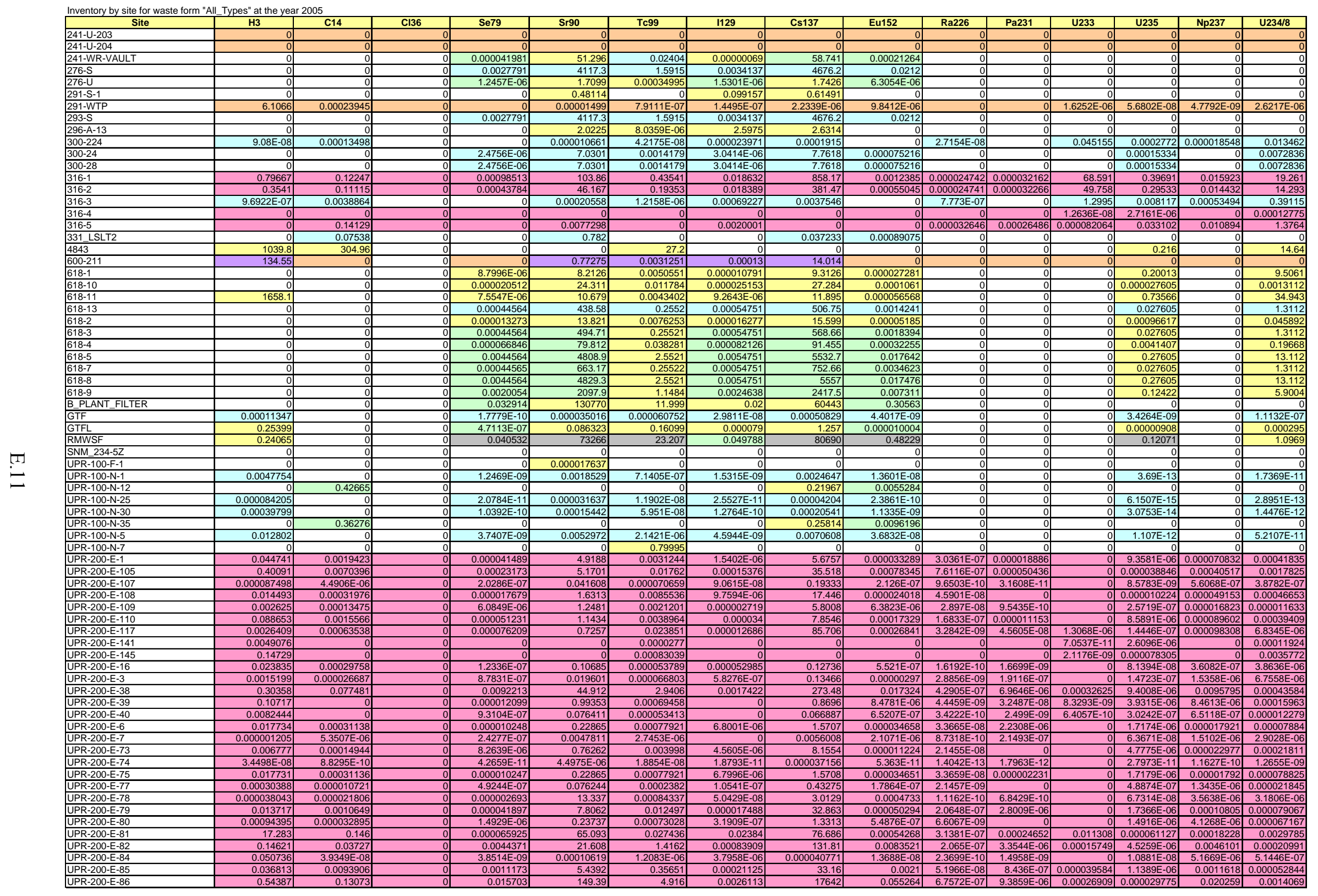




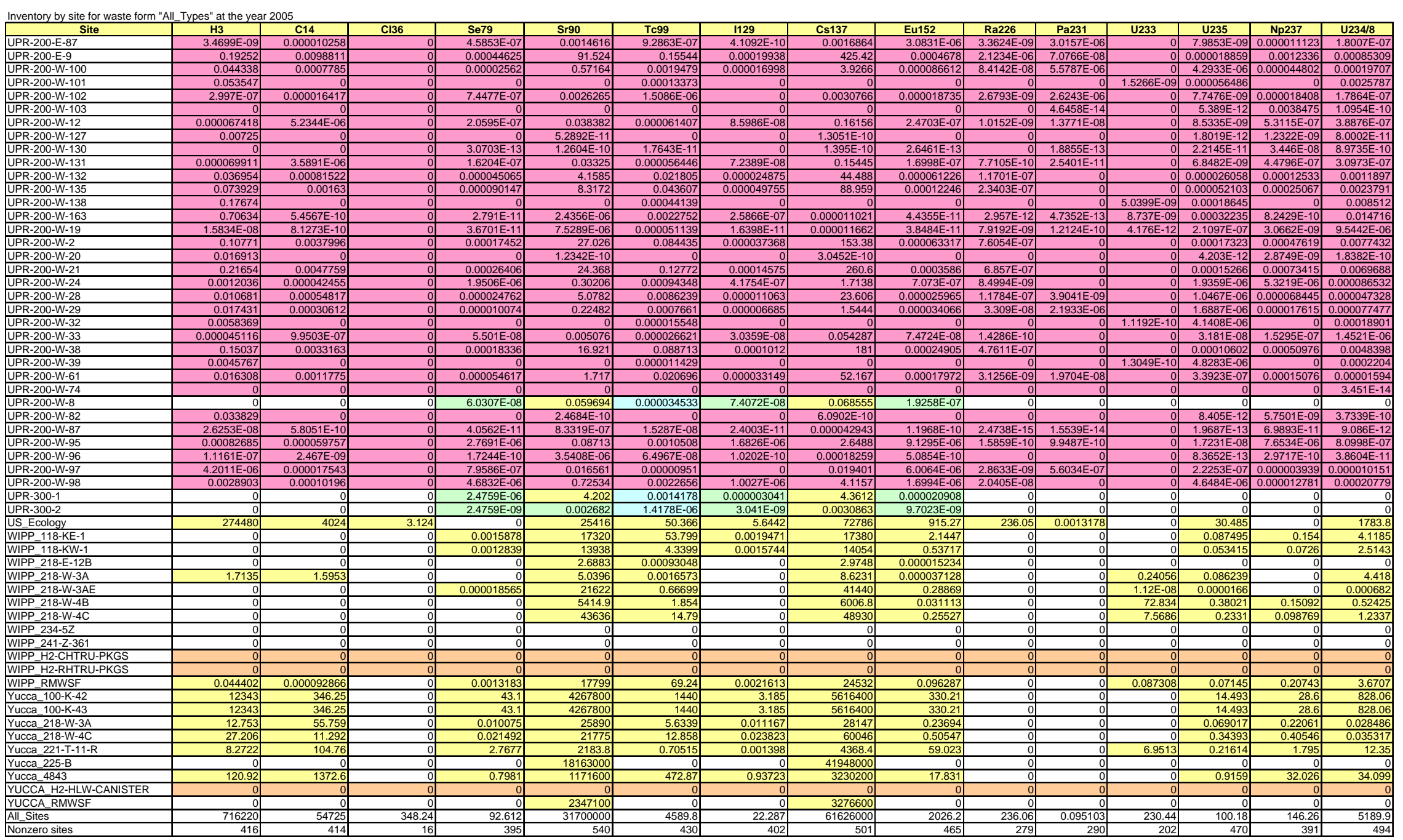




\section{Appendix F}

Best Estimate Inventory - Cumulative in 2035 


\section{Appendix F}

\section{Best Estimate Inventory - Cumulative in 2035}

This appendix presents the best-estimate inventory on December 31, 2035. The inventory input to the simulation is a waste site/year/analyte data file and is quite large because simulations can involve up to 690 waste sites, over 50 years of nuclear materials operations, and up to 14 analytes. The cumulative and decay corrected inventory discharged and disposed by a given date, in this case December 31, 2035, is more readily displayed. When acquiring inventory data and estimates, one often finds or is provided a best-estimate value without regard to its uncertainty distribution. In the case of the stochastic Hanford Soil Inventory Model (SIM) results, the best-estimate is the mean. However, in all other cases the single value found or provided is simply interpreted as the best-estimate. The inventory compilation shown here is the best-estimate value for each waste site and analyte. This inventory was taken from the 'By_Site_2035' tab of the 'Tables_Best_2005_11_17_Inv-Data-Package.xls' file.

The best-estimate inventory shown here is a post-processed file that derives from the waste site/year/ analyte file used to drive the Hanford assessment simulation. The waste site /year/analyte file is created by the INVENTORY code when it applies the uncertainty rules described in Section 6 to the 'disposal action file' of 'daf' created by INPROC. The INPROC code applies the fill-in and surrogate rules described in Section 4 to the inventory data files described in Section 5. The input file for INPROC execution is 'inproc-input_2005-11-09_DCR-0024.csv' and it is under configuration management and maintained on the SAC Windows File server at $\backslash$ sac.pnl.gov\shareldata $\backslash$ rev.1 $\backslash$ inventory $\backslash$ The 'Tables_Best...' and the 'inproc-input...' files are attached as an electronic appendix. In addition the output of the INPROC code for reference case A, (i.e., CA_Ref_A.daf), which is the basis for the bestestimate tables, is also included in the electronic appendix.

The background for table entries has been color coded to indicate the type or source of the data; Hanford SIM result, Hanford Tank Waste Operation Simulator (HTWOS) model result, record, estimated by fill-in rule, and estimated by a surrogate rule, or some combination. A key is provided at the bottom of the table.

While assembling the inventory, every effort was made to be consistent with inventories used in performance assessments being prepared for the single-shell tanks and the integrated disposal facility. Near perfect consistency was achieved by using the same simulation by the HTWOS model (Kirkbride et al. 2005). However, Kirkbride et al. (2005) shows a radium-226 inventory in tank 241-C-106 of 416 curies, decay correct to January 1, 2004. Tank 241-C-106 has been cleaned out and the HTWOS model simply used the Best Basis Inventory (BBI) for this tank as its residual. However, the BBI inventory for radium-226 was in error and has been updated to $1.39 \mathrm{E}-03 \mathrm{Ci}$, and that value is now in the draft performance assessment supporting the closure of single-shell tanks. This inconsistency was discovered during peer review of this document, and the updated value has not been promulgated into this inventory for use in Hanford assessments.

Kirkbride RA, PJ Certa, TM Hohl, AM Johnson, and RS Wittman. 2005. Hanford Tank Waste Operations Simulator Model Data Package for the Development Run for the Refined Target Case. RPP-RPT-23412, Revision 0A, CH2M HILL Hanford Group, Inc., Richland, Washington. 


\begin{tabular}{|c|c|c|c|c|c|c|c|c|c|c|c|c|c|c|c|}
\hline & $\frac{\mathrm{H} 3}{3}$ & $\mathrm{C} 14$ & $\mathrm{Cl} 136$ & Se79 & Sr90 & Tc99 & 1129 & Cs137 & Eu152 & Ra226 & Pa231 & $\mathrm{U} 233$ & $\mathrm{U} 235$ & Np237 & U234/8 \\
\hline \begin{tabular}{|l} 
Inventory at year 2035 \\
Site
\end{tabular} & $\mathrm{H}^{3}$ & C14 & $\mathrm{Cl} 36$ & Se79 & Sr90 $\quad \longrightarrow \quad \longrightarrow$ & Tc99 & 1129 & Cs137 & Eu152 & Ra226 & Pa231 & U233 $>>0$ & & & \\
\hline \begin{tabular}{|l|l|l|l|} 
All sites \\
\end{tabular} & 150793.3572 & 56129.87404 & 348.369813 & 184.8798485 & 35716371.59 & 31323.12872 & 65.38037592 & 51485352.1 & 737.0875966 & T94.4819071 & 6.16445295 & \begin{tabular}{|l|l|}
5 & 954.5495961 \\
\end{tabular} & 109.567882 & \begin{tabular}{|c|}
273.6610879 \\
2
\end{tabular} & 5627.283141 \\
\hline Offsite transfers - WIPP, Yucca & 4597.080361 & 2231.484128 & & 92.62505187 & 33673343.25 & 7368.394388 & 9.60440062 & 50212986.2 & 420.8944401 & 10.010821963 & 4.01291133 & 3 783.1295301 & 40.1564356 & 172.801866 & 2124.091135 \\
\hline & & $3.98 \%$ & $0.00 \%$ & $50.10 \%$ & $94.28 \%$ & $23.52 \%$ & $14.69 \%$ & $97.53 \%$ & $57.10 \%$ & $6 \quad 0.00 \%$ & $65.10 \%$ & $6 \quad 82.04 \%$ & $36.65 \%$ & $63.14 \%$ & $\quad 37.75 \%$ \\
\hline US Ecology & 67442 & 4627.8 & 3.1853 & & 14498 & 53.143 & 5.8347 & 36452 & 197.09 & 282.79 & 0.001317 & & 30.538 & & 1786.9 \\
\hline & $44.72 \%$ & $8.24 \%$ & $0.91 \%$ & $0.00 \%$ & $0.04 \%$ & $0.17 \%$ & $8.92 \%$ & $0.07 \%$ & $26.74 \%$ & $\quad 40.72 \%$ & & & & & $31.75 \%$ \\
\hline All onsite DOE waste & 78754.27683 & 49270.58992 & 345.184513 & 92.25479661 & 2028530.339 & 23901.59134 & 49.9412753 & 1235913.898 & 119.1031565 & $5 \quad 411.6810851$ & 2.15022462 & 171.420066 & 38.87344636 & 100.8592219 & 1716.292006 \\
\hline & $52.23 \%$ & $87.78 \%$ & $99.09 \%$ & $49.90 \%$ & $5.68 \%$ & $76.31 \%$ & $76.39 \%$ & $2.40 \%$ & $16.16 \%$ & $59.28 \%$ & $34.88 \%$ & $17.96 \%$ & $35.48 \%$ & $36.86 \%$ & $30.50 \%$ \\
\hline IDF only & 112.65952 & 795.7262 & 0.00013072 & 89.30800544 & 734976.4024 & 22740.00348 & 40.5113583 & 345783.956 & 20.66009075 & 1.4009 & 1.9436 & 15.897 & 0.42028 & 43.715 & 18.35526 \\
\hline & $0.14 \%$ & $1.62 \%$ & $0.00 \%$ & $96.81 \%$ & $36.23 \%$ & $95.14 \%$ & $81.12 \%$ & $27.98 \%$ & $17.35 \%$ & $\quad 0.34 \%$ & $90.39 \%$ & $9.27 \%$ & $1.08 \%$ & \% $\quad 43.34 \%$ & $1.07 \%$ \\
\hline River Corridor waste sites & 15587.62929 & 47761.92601 & 344.961 & 0.015964321 & 7467.295092 & 36.56459865 & 0.056275284 & 9614.523924 & 77.32681292 & $28.18611 \mathrm{E}-05$ & 0.000329077 & $7 \quad 119.6776311$ & 2.664533543 & $\begin{array}{ll}3 & 0.042454788\end{array}$ & 131.397097 \\
\hline including reactor cores & $19.79 \%$ & $96.94 \%$ & $99.94 \%$ & $0.02 \%$ & $0.37 \%$ & $0.15 \%$ & $0.11 \%$ & $0.78 \%$ & $64.92 \%$ & $\quad 0.00 \%$ & $0.02 \%$ & $\quad 69.82 \%$ & $6.85 \%$ & $\quad 0.04 \%$ & $7.66 \%$ \\
\hline CP - Other "218" waste sites & 36707.39149 & 507.796381 & 0.22338232 & 0.558192984 & 404726.8314 & 259.1945119 & 1.137369121 & 583192.4216 & 1.408492216 & & & 0.525735851 & 32.47493767 & $\begin{array}{ll}7 & 0.114358874\end{array}$ & 1415.073426 \\
\hline & $46.61 \%$ & $1.03 \%$ & & $0.61 \%$ & $19.95 \%$ & $1.08 \%$ & $2.28 \%$ & $47.19 \%$ & $1.18 \%$ & $0.00 \%$ & $0.00 \%$ & $0.31 \%$ & $\quad 83.54 \%$ & \% & $82.45 \%$ \\
\hline CP - "216" waste sites & 26310.96509 & 192.0557956 & & 1.82743947 & 8262.845545 & 578.1745012 & 4.548183764 & 21720.74261 & 0.495440891 & 0.009835981 & 0.085971144 & $4 \quad 22.49195993$ & 2.218472152 & 53.37042854 & 100.6171799 \\
\hline & $33.41 \%$ & $0.39 \%$ & $0.00 \%$ & $1.98 \%$ & $0.41 \%$ & $2.42 \%$ & $9.11 \%$ & $1.76 \%$ & $0.42 \%$ & $0.00 \%$ & $4.00 \%$ & $13.12 \%$ & $5.71 \%$ & $52.92 \%$ & $5.86 \%$ \\
\hline$C P$-facilities & 10.44202098 & 0.0088281 & & 0.080644558 & 190377.1397 & 38.35783229 & 2.76694461 & 135679.5877 & 0.168949104 & 0.000002117 & & 0.00021999 & 0.636019773 & 0.00015115 & 29.88093227 \\
\hline & $0.01 \%$ & $0.00 \%$ & $0.00 \%$ & $0.09 \%$ & & $0.16 \%$ & $5.10044 \%$ & $10.98 \%$ & $0.14 \%$ & $0.00 \%$ & $\quad 0.00 \%$ & $0.000 \%$ & $1.64 \%$ & $\quad 0.00 \%$ & $\quad 1.74 \%$ \\
\hline CP - "200" waste sites & 2.747497133 & 0.053744131 & & 0.01441151 & 11806.55269 & 5.381008997 & 0.65256357 & 10249.45467 & 0.138588829 & $9 \quad 4.47442 \mathrm{E}-06$ & 0.001081182 & 20.018510029 & 0.021266887 & 70.011968236 & 0.971270856 \\
\hline & $0.00 \%$ & $0.00 \%$ & $0.00 \%$ & $0.02 \%$ & $0.58 \%$ & $0.02 \%$ & $1.31 \%$ & $0.83 \%$ & $0.12 \%$ & $\quad 0.00 \%$ & $0.05 \%$ & $\quad 0.01 \%$ & $\quad 0.05 \%$ & $\quad 0.01 \%$ & $0.06 \%$ \\
\hline CP - UPR waste sites & 3.910230374 & 0.440422727 & & 0.032387653 & 245.8583319 & 10.29771377 & 0.030181728 & 9820.532028 & 0.018772844 & $4 \quad 7.88193 \mathrm{E}-06$ & 0.000369141 & 10.012099642 & 0.001388495 & $\begin{array}{ll}5 & 0.044235719\end{array}$ & 0.063438694 \\
\hline & $0.00 \%$ & $0.00 \%$ & $0.00 \%$ & $0.04 \%$ & $0.01 \%$ & $0.04 \%$ & $0.06 \%$ & $0.79 \%$ & $0.02 \%$ & $0.00 \%$ & $\quad 0.02 \%$ & \% $\quad 0.01 \%$ & $\quad 0.00 \%$ & $0.04 \%$ & $0.00 \%$ \\
\hline CP - tank "241" waste sites & 18.53168823 & 12.58252975 & 0 & 0.417750677 & 670667.414 & 233.6176879 & 0.238398924 & 119852.6794 & 18.88600899 & 410.2702528 & 0.118874076 & 12.79690948 & 0.436547836 & 3.560624634 & 19.93340141 \\
\hline & & & & & $33.06 \%$ & & & & $15.86 \%$ & $\quad 99.66 \%$ & $5.53 \%$ & & $1.12 \%$ & $3.53 \%$ & $1.16 \%$ \\
\hline Subtotal onsite DOE waste & 78754.27683 & 49270.58992 & 345.184513 & 92.25479661 & 2028530.339 & 23901.59134 & 49.9412753 & 1235913.898 & 119.1031565 & 5411.6810851 & 2.15022462 & 171.420066 & 38.87344636 & 100.8592219 & 1716.292006 \\
\hline & 78754.27683 & 49270.58992 & 345.184513 & 92.25479661 & 2028530.339 & 23901.59134 & 49.9412753 & 1235913.898 & 119.1031565 & $5 \quad 411.6810851$ & 2.15022462 & 171.420066 & 38.87344636 & $\begin{array}{l}6 \quad 100.8592219 \\
\end{array}$ & 1716.292006 \\
\hline \begin{tabular}{|l} 
Analyte \\
SIM Data
\end{tabular} & & C14 & $\mathrm{Cl36}$ & \begin{tabular}{|l|} 
Se79 \\
\end{tabular} & \begin{tabular}{l|} 
Sr90 \\
\end{tabular} & Tc99 & 1129 & \begin{tabular}{l|l} 
Cs137 \\
\end{tabular} & \begin{tabular}{|l|l} 
Eu152 \\
\end{tabular} & Ra226 & Pa231 & \begin{tabular}{l|l}
$\mathrm{U} 233$ \\
\end{tabular} & U235 & Np237 & $U 234 / 8$ \\
\hline SIM Data & 24723.61 & 196.3498 & & 2.147856 & 22168.15 & 686.8757 & 4.725018 & 99318.05 & 0.7784551 & 0.009992014 & 0.09264544 & 140.8508 & 3.097366 & & 4 \\
\hline & $16.40 \%$ & $0.35 \%$ & $0.00 \%$ & 1. & $0.06 \%$ & $2.19 \%$ & $7.23 \%$ & $0.19 \%$ & $0.11 \%$ & $0.00 \%$ & $1.50 \%$ & 14. & $2.83 \%$ & $19.66 \%$ & $2.53 \%$ \\
\hline HTWOS Data & 1642.412 & 804.5786 & & 92.2 & 20314710 & & 42.87137 & 20595340 & & & & & & 127.3996 & 433.4033 \\
\hline & $1.09 \%$ & $1.43 \%$ & $0.00 \%$ & $49.91 \%$ & $56.88 \%$ & $85.33 \%$ & $65.57 \%$ & $40.00 \%$ & $40.79 \%$ & $59.28 \%$ & $98.46 \%$ & $75.86 \%$ & $8.50 \%$ & & $7.70 \%$ \\
\hline Record Data & 124232.8 & 55057.02 & 348.3701 & 89.81152 & 15331980 & 3880.089 & 17.17016 & 30698660 & 393.8171 & 282.7906 & 0.00131697 & 88.19618 & 96.22503 & 92.4463 & 5039.227 \\
\hline & $82.39 \%$ & $\begin{array}{r}98.09 \% \\
308574\end{array}$ & $100.00 \%$ & $48.58 \%$ & $\begin{array}{l}42.93 \% \\
427715\end{array}$ & $\begin{array}{r}12.39 \% \\
2377553\end{array}$ & $\begin{array}{r}26.26 \% \\
060465\end{array}$ & $\begin{array}{r}59.63 \% \\
8606414\end{array}$ & $\begin{array}{r}53.43 \% \\
783344\end{array}$ & $40.72 \%$ & $0.02 \%$ & $9.24 \%$ & $\begin{array}{r}87.82 \% \\
668782\end{array}$ & $33.78 \%$ & $89.55 \%$ \\
\hline Estimated Data & & 30.85774 & & 0.6436884 & 42771.5 & 23.75753 & 0.604654 & 86064.14 & 7.83344 & & & & 0.6668782 & & 1.28093E-05 \\
\hline Surrogate Data & $\begin{array}{r}0.00 \% \\
048767\end{array}$ & $\begin{array}{r}0.05 \% \\
41.13153\end{array}$ & $0.00 \%$ & $\begin{array}{r}0.35 \% \\
0\end{array}$ & $0.12 \%$ & $0.08 \%$ & $\begin{array}{r}0.92 \% \\
\end{array}$ & $0.17 \%$ & $1.06 \%$ & $\quad 0.00 \%$ & $\quad 0.00 \%$ & $0.00 \%$ & $0.61 \%$ & $0 \quad 0.00 \%$ & $0.00 \%$ \\
\hline Surrogate Lata & 194.8767 & 41.131153 & & $0.00 / 763553$ & 4380.733 & $3.91081 \%$ & 0.008751153 & 5688.388 & 34.01047 & 7 5.19274E-06 & 0.001080688 & 1.363016 & 0.2602632 & 20.008197745 & 12.27392 \\
\hline Total & \begin{tabular}{|c|c|c|}
150793.7 \\
\end{tabular} & $\begin{array}{r}56129.94 \\
\end{array}$ & $\frac{.00 \% 1}{348.3701}$ & $\begin{array}{r}0.00 \% \\
184.8809\end{array}$ & $\frac{0.07 \%}{35716020}$ & $\begin{array}{r}3.07 \% \\
31322.75 \\
\end{array}$ & $\begin{array}{r}0.01 \% \\
65.37996 \\
\end{array}$ & $\begin{array}{r}0.01 \% \\
51485070 \\
\end{array}$ & $\begin{array}{c}4.61 \% \\
737.0853\end{array}$ & $\begin{array}{r}0.00 \% \\
694.4805\end{array}$ & $\begin{array}{r}0.02 \% \\
6164487 \\
\end{array}$ & $\begin{array}{r}0.14 \% \\
954531\end{array}$ & $\begin{array}{r}0.24 \% \\
\end{array}$ & $\begin{array}{r}0.00 \% \\
2736598\end{array}$ & $0.22 \%$ \\
\hline & & & & & & & & & & & & & & & \\
\hline & & & & & & & & & & & & & & & \\
\hline & $R e$ & & & & & & & & & & & & & & \\
\hline Color 4 & Estimate (fillin- & & & & & & & & & & & & & & \\
\hline Color 5 & Surrogate rule & & & & & & & & & & & & & & \\
\hline Color 7 & Combination of & & & & & & & & & & & & & & \\
\hline Color 8 & c & & & & & & & & & & & & & & \\
\hline Color 9 & Multiple rules & & & & & & & & & & & & & & \\
\hline Color 10 & & & & & & & & & & & & & & & \\
\hline
\end{tabular}


Inventory by site for waste form "All_ Types" at the year 2035

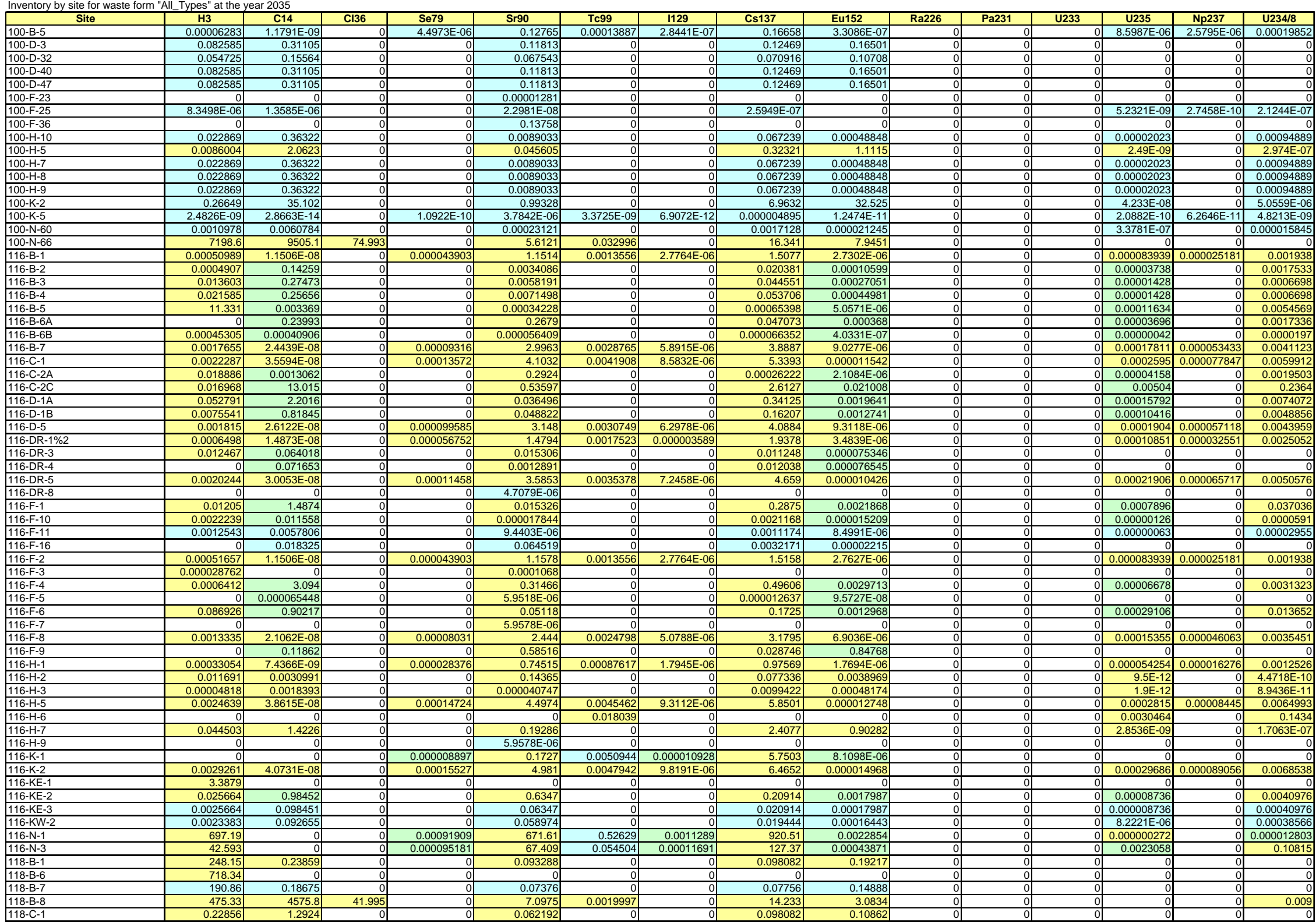


Inventory by site for waste form "All__types" at the year 2035

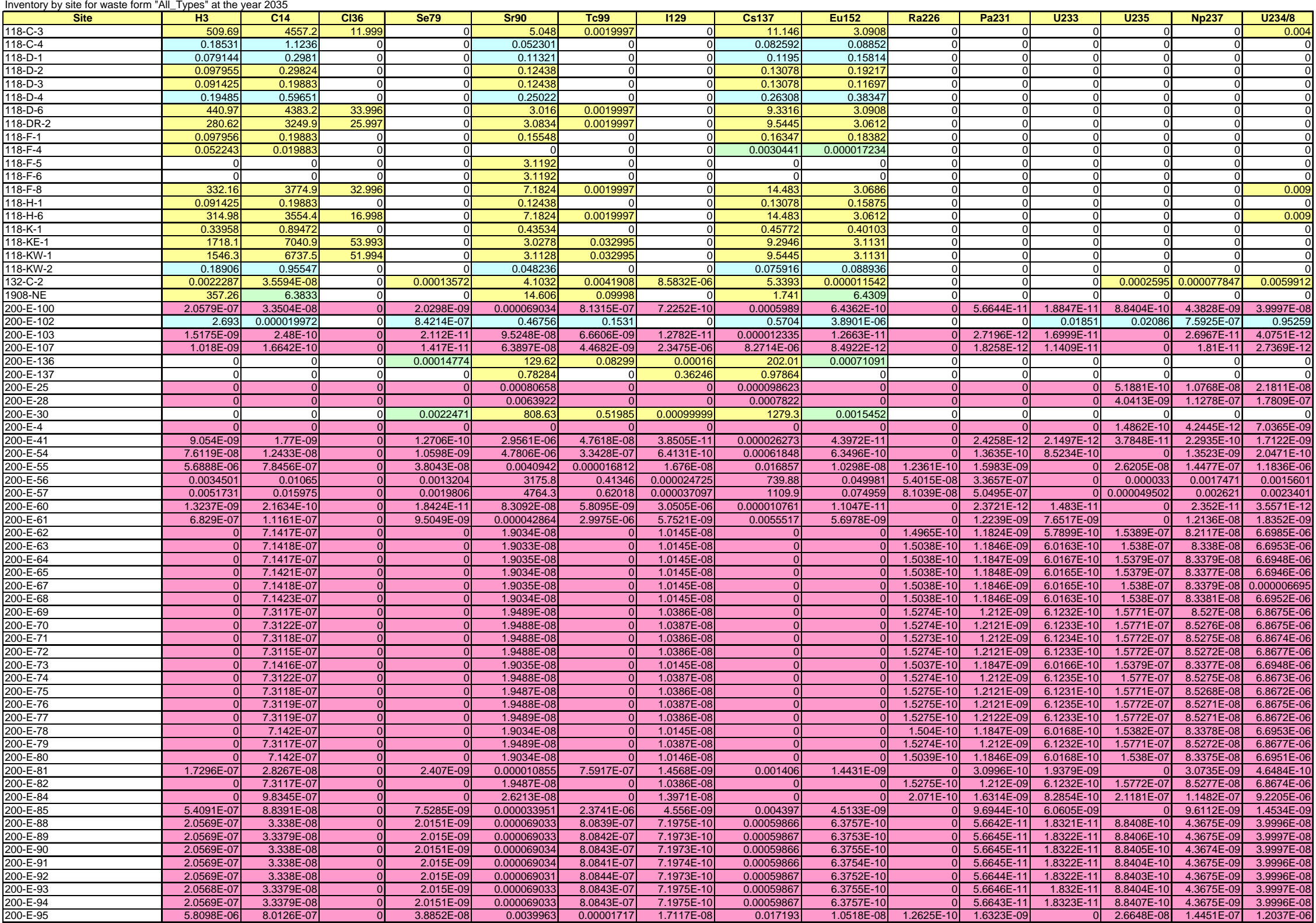


Inventory by site for waste form "All_ Types" at the year 2035

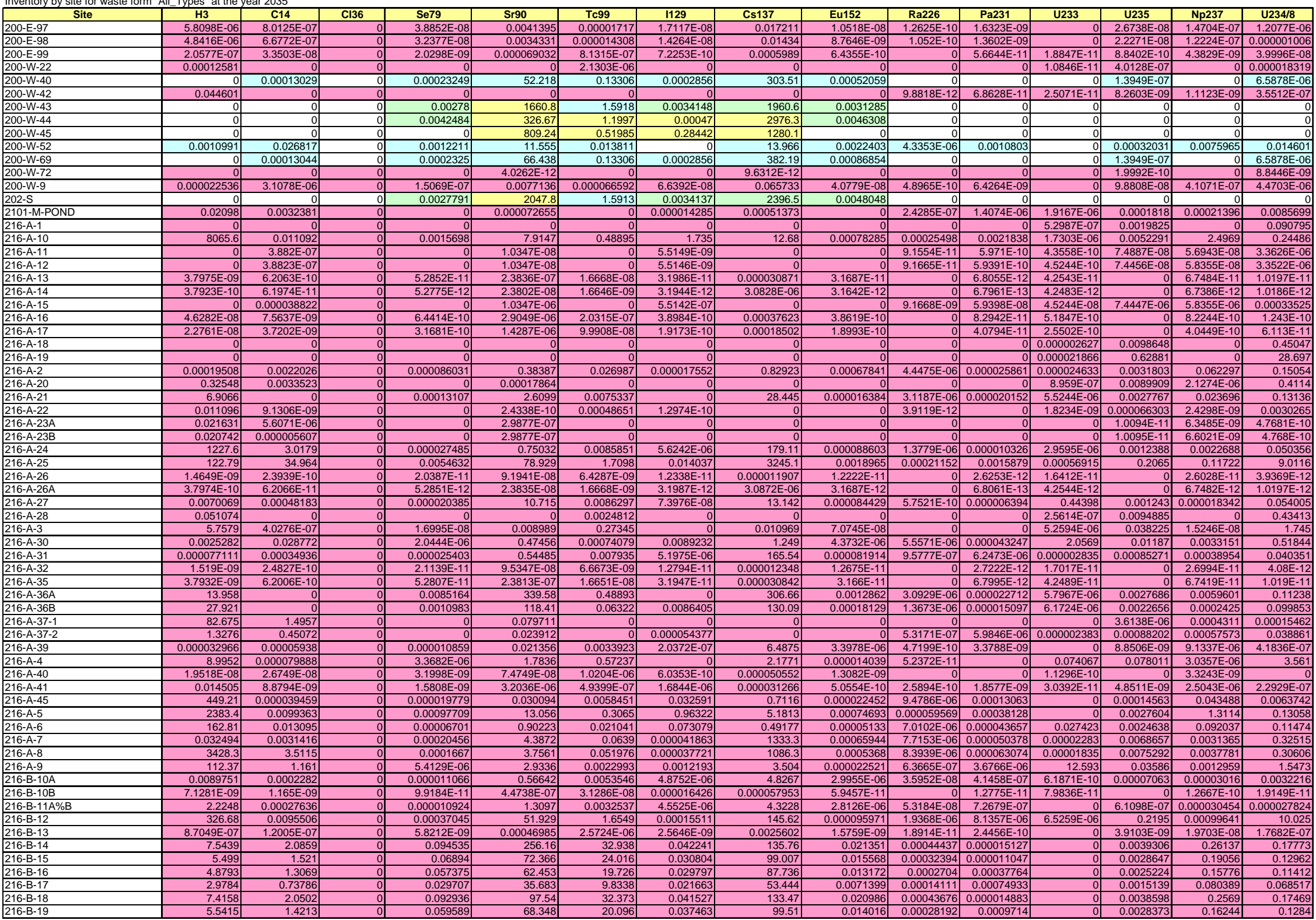


Inventory by site for waste form "All_Types" at the year 2035

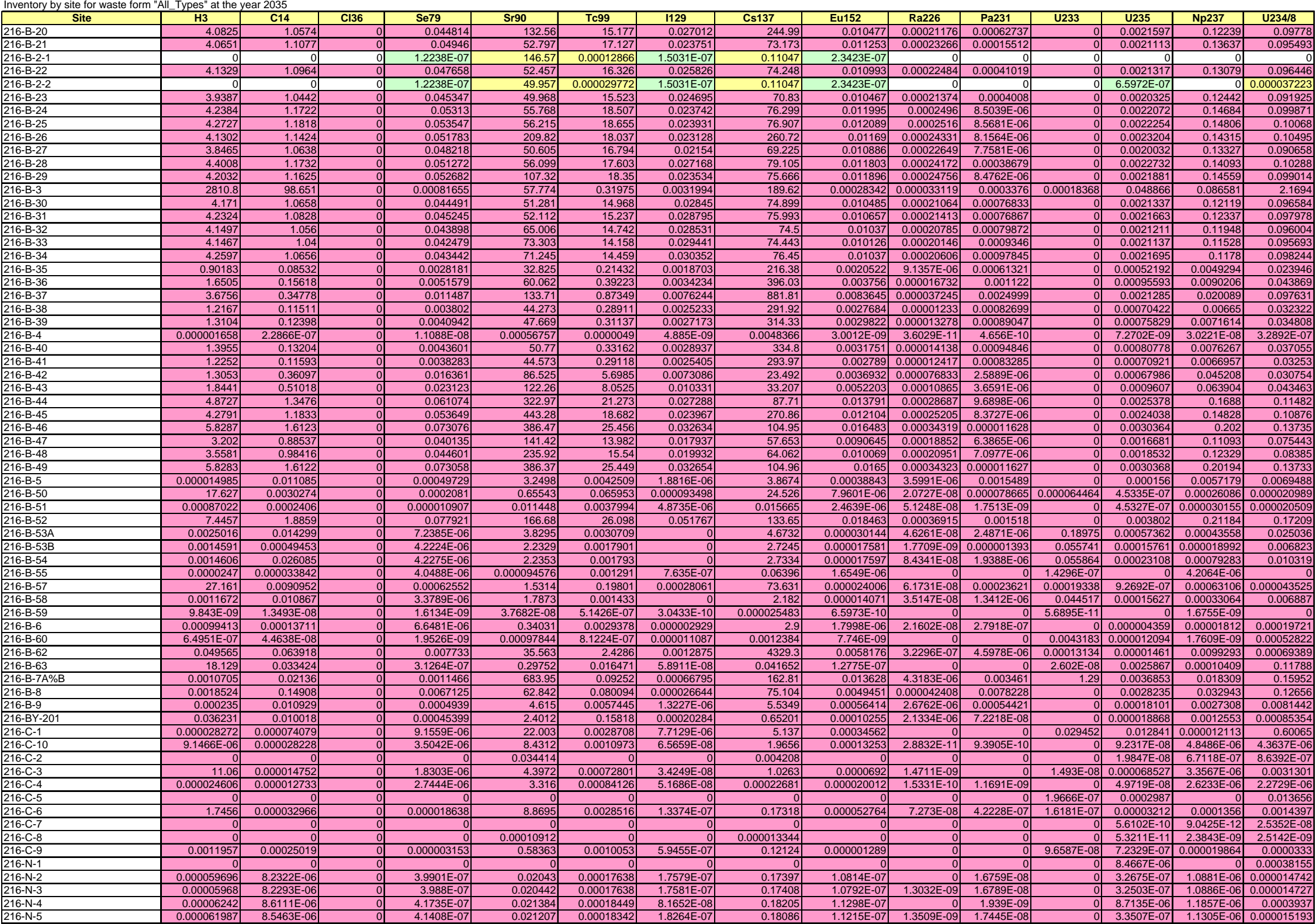


Inventory by site for waste form "All_ Types" at the year 2035

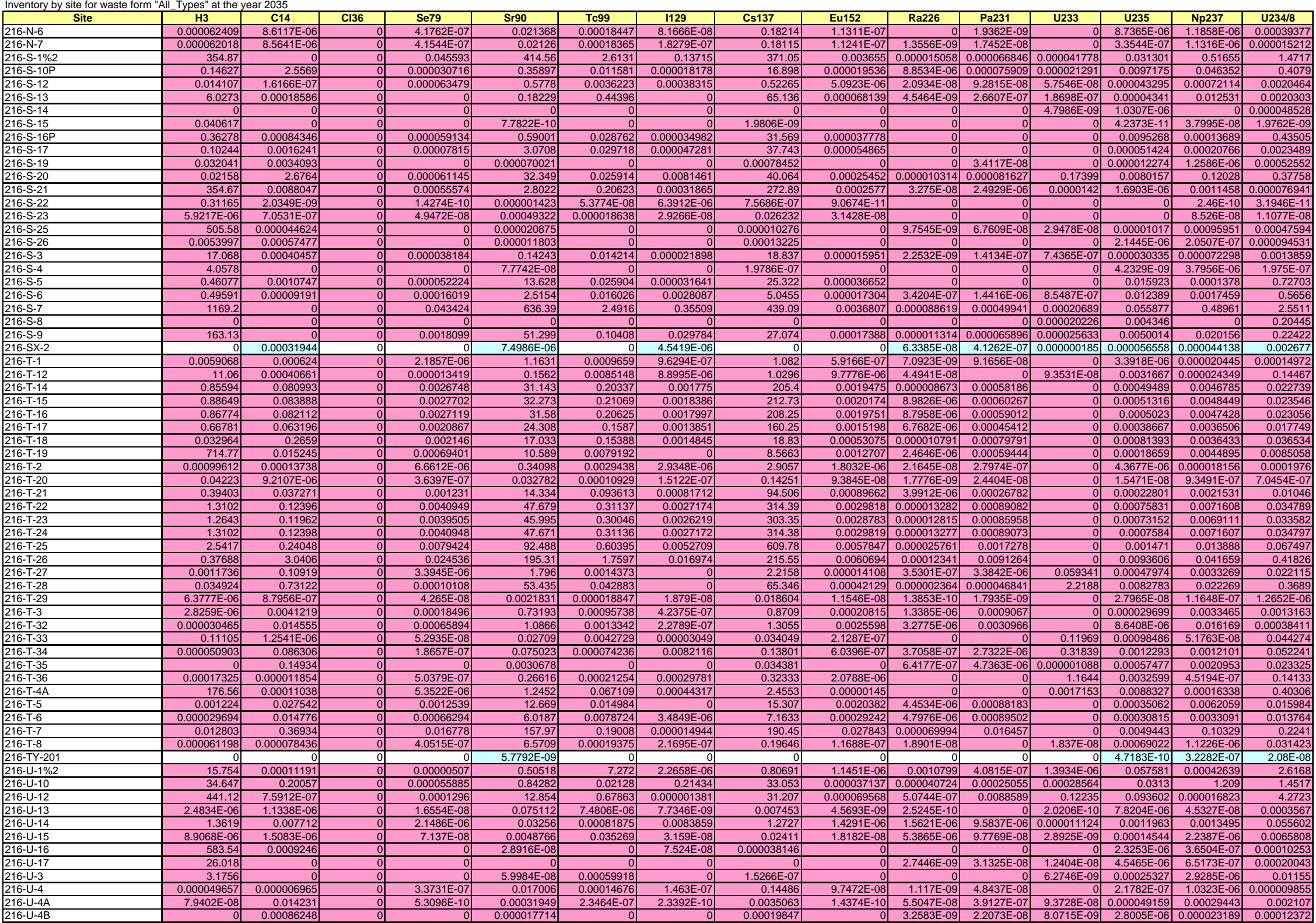


Inventory by site for waste form "All_Types" at the year 2035

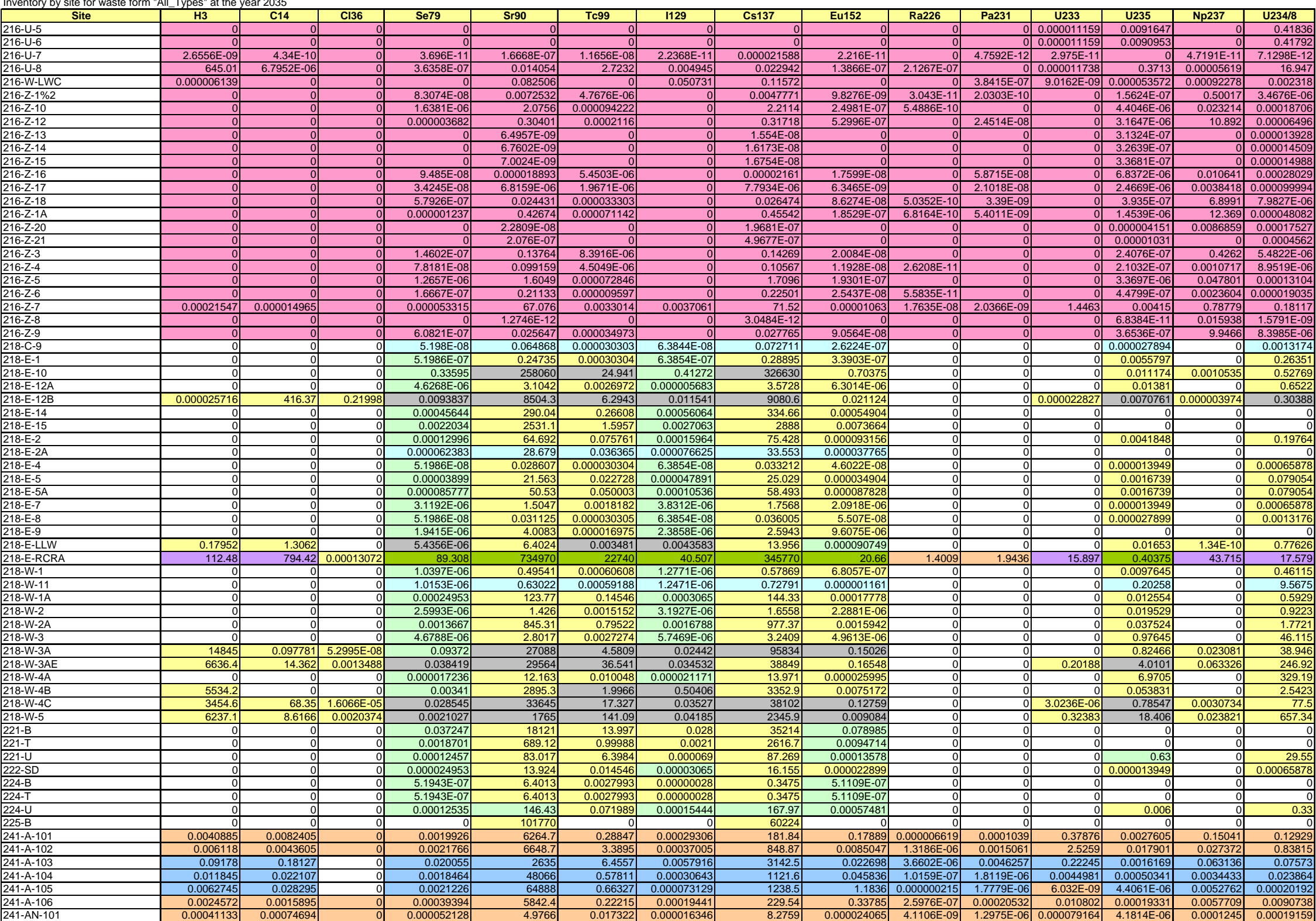


Inventory by site for waste form "All__types" at the year 2035

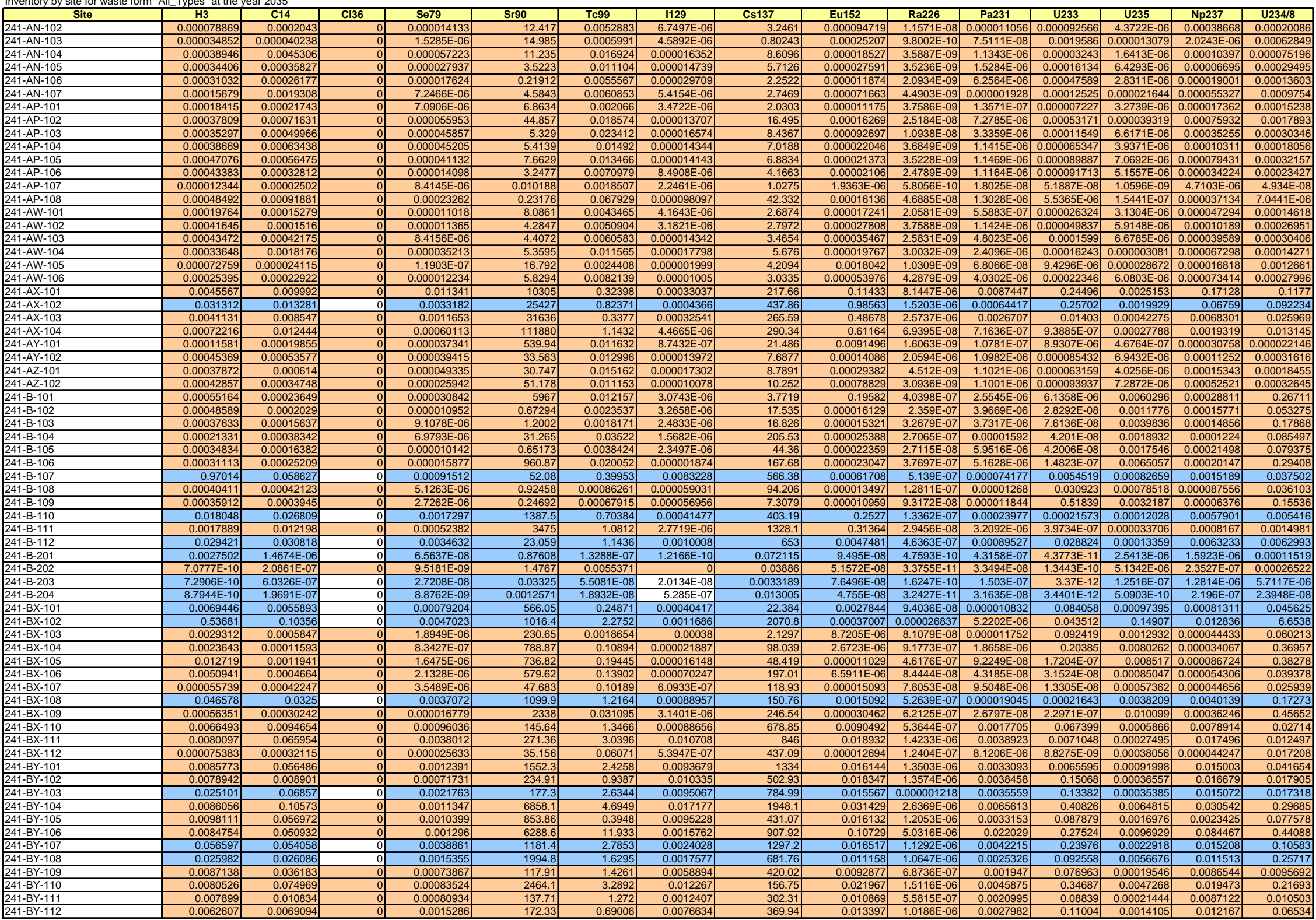


Inventory by site for waste form "All_Types" at the year 2035

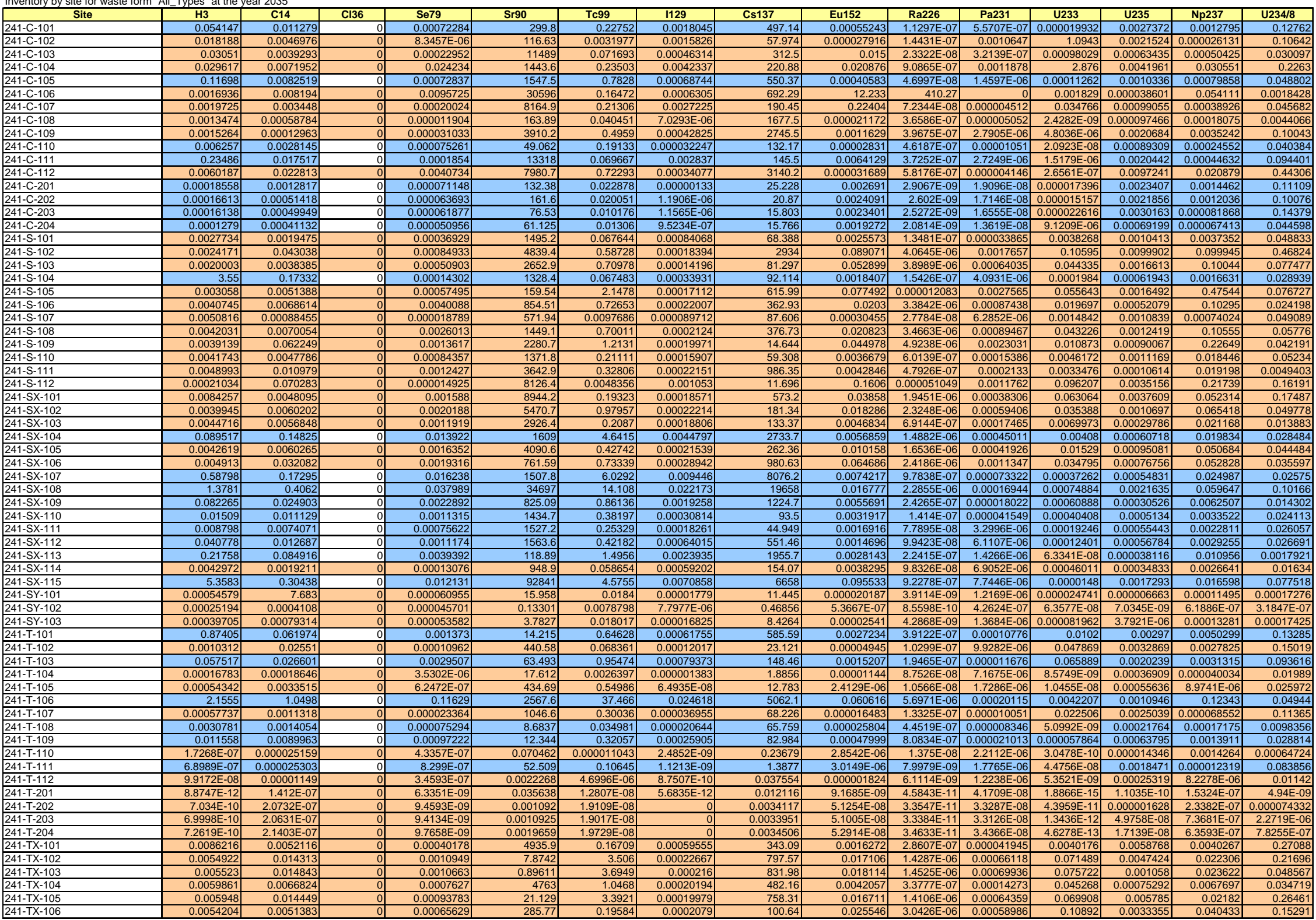


Inventory by site for waste form "All_Types" at the year 2035

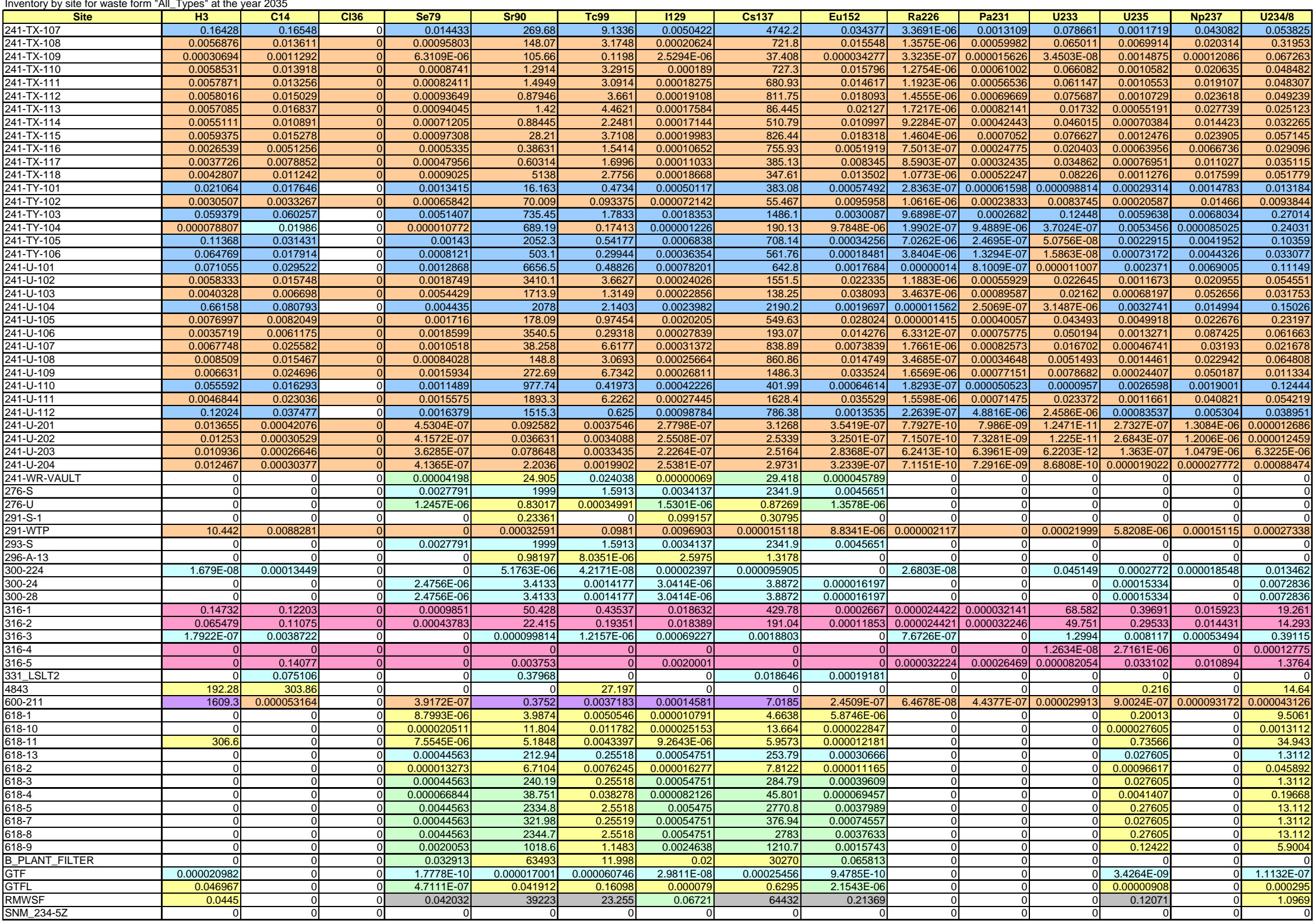


Inventory by site for waste form "All_ Types" at the year 2035

\begin{tabular}{|c|c|c|c|c|c|c|c|c|c|c|c|c|c|c|c|}
\hline Site & $\mathrm{H} 3$ & $\mathrm{C} 14$ & $\mathrm{Cl} 36$ & Se79 & Sr90 & Tc99 & 1129 & Cs137 & Eu152 & Ra226 & Pa231 & U233 & U235 & Np237 & U234/8 \\
\hline UPR-100-F-1 & & & & & $8.5633 \mathrm{E}-06$ & & & & & & & & & & \\
\hline $\begin{array}{l}\text { UPR-100-N-1 } \\
\text { UPR-100-N-12 }\end{array}$ & 0.00088304 & & & $1.2469 \mathrm{E}-09$ & 0.0008996 & $7.1398 \mathrm{E}-07$ & $1.5315 \mathrm{E}-09$ & 0.0012343 & $2.9287 \mathrm{E}-09$ & & & & $3.69 \mathrm{E}-13$ & & $1.7369 \mathrm{E}-11$ \\
\hline UPR-100-N-12 & & 0.4251 & & & & & & 0.11001 & 0.0011905 & & & & & & \\
\hline $\begin{array}{l}\text { UPR-100-N-25 } \\
\end{array}$ & $\frac{0.000015571}{0.0202505}$ & & & $2.0783 \mathrm{E}-11$ & $\begin{array}{l}0.00001536 \\
0.0007075\end{array}$ & $1.1901 \mathrm{E}-08$ & $2.5527 E-11$ & 0.000021054 & 5.1381E-11 & & & & $6.1507 \mathrm{E}-15$ & & $\begin{array}{l}2.8951 E-13 \\
.1575-12\end{array}$ \\
\hline UPR-100-N-30 & 0.000073595 & & & $1.0392 \mathrm{E}-10$ & 0.000074975 & $5.9505 E-08$ & $1.2764 \mathrm{E}-10$ & $\begin{array}{c}0.00010287 \\
\end{array}$ & $2.4409 E-10$ & & & & $3.0753 \mathrm{E}-1$ & & $1.4476 \mathrm{E}-12$ \\
\hline UPR-100-N-35 & & 0.36145 & & & & & & $\begin{array}{r}0.12928 \\
\end{array}$ & & & & & & & \\
\hline UPR-100-N-5 & 0.0023672 & & & $3.7406 \mathrm{E}-09$ & 0.0025719 & $2.1419 \mathrm{E}-06$ & $4.5944 \mathrm{E}-09$ & 0.0035361 & $7.9312 E-09$ & & & & $1.107 E-12$ & & $5.2107 E-11$ \\
\hline UPR-100-N-7 & & & & & & 0.79987 & & & & & & & & 0 & \\
\hline UPR-200-E-1 & $\begin{array}{l}0.0082734 \\
\end{array}$ & $\begin{array}{l}0.0019353 \\
\end{array}$ & & $\begin{array}{l}0.000041488 \\
\end{array}$ & $\begin{array}{l}2.3882 \\
25102\end{array}$ & 0.0031241 & $1.5402 \mathrm{E}-06$ & 2.8424 & $\begin{array}{l}7.1683 E-06 \\
\end{array}$ & $2.9969 \mathrm{E}-07$ & 0.000018874 & & $9.3581 \mathrm{E}-0 \mathrm{t}$ & .000070832 & 0.00041835 \\
\hline $\begin{array}{l}\text { UPR-200-E-105 } \\
\text { UPR-200-E-107 }\end{array}$ & $\begin{array}{r}0.074134 \\
0.00001618\end{array}$ & \begin{tabular}{|r|}
0.007014 \\
$4.4743-066$
\end{tabular} & & $\begin{array}{l}0.00023172 \\
20285 E-07\end{array}$ & $\begin{array}{r}2.5102 \\
0.020202 \\
\end{array}$ & $\begin{array}{r}0.017619 \\
0.0007062 \\
\end{array}$ & $\begin{array}{l}0.00015376 \\
0015 E\end{array}$ & $\begin{array}{r}17.788 \\
009681\end{array}$ & 0.00016871 & $\begin{array}{l}7.5133 \mathrm{E}-07 \\
0.5257 \mathrm{~F}-10\end{array}$ & \begin{tabular}{|l|l|}
0.000050404 \\
31505
\end{tabular} & & $\frac{0.000038844}{857250}$ & 0.00040517 & $\begin{array}{l}0.0017825 \\
0.070207\end{array}$ \\
\hline UPR-200-E-107 & 0.00001618 & 4.4743E-06 & & 2.0285E-07 & $\begin{array}{l}0.020202 \\
\end{array}$ & 0.000070652 & $\begin{array}{l}9.0615 E-08 \\
0.70150 A\end{array}$ & $\begin{array}{r}0.096821 \\
87271 \\
\end{array}$ & $\begin{array}{r}4.5782 \mathrm{E}-08 \\
\end{array}$ & $9.5257 \mathrm{E}-10$ & 3.1588E-11 & & $8.5783 \mathrm{E}-\mathrm{O}$ & 5.6067E-07 & 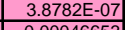 \\
\hline $\begin{array}{l}\text { UPR-200-E-108 } \\
\text { UPR-200-E-109 }\end{array}$ & 0.0026799 & $\begin{array}{r}0.0003186 \\
\end{array}$ & & 0.000017679 & $\begin{array}{l}0.79201 \\
\end{array}$ & 0.0085528 & $\begin{array}{r}9.7594 \mathrm{E}-06 \\
\end{array}$ & $\begin{array}{r}8.7371 \\
\end{array}$ & 0.000005172 & $4.5309 \mathrm{E}-08$ & 0 & & 0.00001022 & $\begin{array}{l}4 \quad 0.000049152 \\
\end{array}$ & 0.00046653 \\
\hline$\frac{U P R-200-E-109}{U P R-200-E-110}$ & $\begin{array}{c}0.00048539 \\
0.016393 \\
\end{array}$ & $\begin{array}{r}0.00013426 \\
0.001551\end{array}$ & & $\begin{array}{r}6.08475-06 \\
0.000051229\end{array}$ & 0.60598 & 0.0021199 & $\begin{array}{r}0.000002719 \\
0.000034\end{array}$ & $\begin{array}{l}2.9051 \\
3.9336\end{array}$ & $\begin{array}{r}1.3744 \mathrm{E}-06 \\
0.000037316\end{array}$ & $\frac{2.8596-0 \mathrm{E}-08}{1.6616-07}$ & $\frac{9.5335 E-10}{0.000011146}$ & & $\frac{2.5519 \mathrm{E}-07}{8.5891 \mathrm{E}-06}$ & $\frac{0.000016822}{0.00008601}$ & .000011633 \\
\hline UPR-200-E-117 & 0.00048834 & 0.00063308 & & 0.000076206 & 0.35235 & 0.023848 & 0.000012686 & 42.922 & 0.000057799 & $3.2418 \mathrm{E}-09$ & $4.5576 \mathrm{E}-08$ & $1.3066 \mathrm{E}-0 \mathrm{G}$ & $\frac{8.5891 \mathrm{E}-0 \mathrm{t}}{1.4446 \mathrm{E}-07}$ & 0000098307 & $\frac{0.000394409}{6.8345 E-06}$ \\
\hline UPR-200-E-141 & 0.0009075 & & & & & 0.000027697 & & & & & & $7.0528 \mathrm{E}-1$ & $2.6096 \mathrm{E}-\mathrm{OC}$ & & $\frac{6.83455-06}{0.00011924}$ \\
\hline UPR-200-E-145 & 0.027237 & & & & & 0.00083031 & & & 0 & & & $2.1173 \mathrm{E}-0 \mathrm{O}$ & 0.00007830 & & 0.0035772 \\
\hline UPR-200-E-16 & 0.0044074 & 0.0002965 & & $1.2336 \mathrm{E}-07$ & 0.051879 & 0.000053784 & 0.000052985 & 0.063781 & $1.1889 \mathrm{E}-07$ & $1.5983 \mathrm{E}-10$ & $1.6688 \mathrm{E}-09$ & & $8.1394 \mathrm{E}-0$ & $3.6082 \mathrm{E}-07$ & $3.8636 \mathrm{E}-06$ \\
\hline UPR-200-E-3 & 0.00028105 & 0.00002659 & & $8.7828 \mathrm{E}-07$ & 0.0095166 & 0.000066796 & $5.8275 \mathrm{E}-07$ & 0.067438 & $6.3955 E-07$ & $2.8484 \mathrm{E}-09$ & $1.9103 \mathrm{E}-07$ & & $1.4723 \mathrm{E}-0$ & $1.5358 \mathrm{E}-06$ & $6.7558 \mathrm{E}-06$ \\
\hline UPR-200-E-38 & 0.056137 & \begin{tabular}{|l}
0.077199 \\
\end{tabular} & & 0.009221 & 21.806 & 2.9403 & $\begin{array}{l}0.0017422 \\
\end{array}$ & 136.96 & 0.0037306 & $4.2351 \mathrm{E}-07$ & $6.9602 \mathrm{E}-06$ & 0.0003262 & $9.4008 \mathrm{E}-06$ & 0.0095795 & 0.00043584 \\
\hline UPR-200-E-39 & 0.019817 & & & 0.000012099 & $\begin{array}{r}0.48238 \\
0.723\end{array}$ & $\begin{array}{c}0.00069451 \\
\end{array}$ & & 0.4355 & $1.8256 \mathrm{E}-06$ & $\begin{array}{l}4.3885 E-09 \\
.820-2\end{array}$ & $3.2466 \mathrm{E}-08$ & $8.3282 \mathrm{E}-0$. & $3.9315 \mathrm{E}-06$ & $8.4612 \mathrm{E}-06$ & 0.00015963 \\
\hline UPR-200-E-40 & 0.0015245 & & & $9.3101 \mathrm{E}-07$ & & 0.000053408 & & & $1.4041 E-07$ & $3.378 \mathrm{E}-10$ & & $6.4049 \mathrm{E}-1$ & & $6.5118 \mathrm{E}-07$ & \\
\hline $\begin{array}{l}\text { UPR-200-E-6 } \\
\text { UPR-200-E- }\end{array}$ & $\begin{array}{r}0.0032793 \\
2.2283-07\end{array}$ & 0.00031025 & & $\begin{aligned} 0.000010247 \\
2476 \mathrm{E}-07\end{aligned}$ & $\begin{array}{r}0.11102 \\
0.0023213\end{array}$ & $\begin{array}{r}0.00077913 \\
0.000002745\end{array}$ & $\begin{array}{r}0.0000068 \\
0\end{array}$ & $\begin{array}{r}0.78664 \\
0.0028049 \\
\end{array}$ & $\begin{array}{l}7.4632 E-06 \\
4.5375-07\end{array}$ & $\begin{array}{r}\frac{3.3231 E-08}{8.619 E-10} \\
\frac{10}{2}\end{array}$ & $\begin{array}{l}2.2294 \mathrm{E}-06 \\
21479 \mathrm{E}-07\end{array}$ & & $\frac{1.7174 \mathrm{E}-06}{6.3761 \mathrm{E}-08}$ & 0.000017921 & $\frac{0.00007884}{29028-66}$ \\
\hline UPR-200-E- -2 & $\frac{2.22835-0}{0.0012532}$ & $\begin{array}{l}5.03313-00 \\
0.00014889\end{array}$ & & $\begin{array}{l}2.4266 \mathrm{E}-01 \\
8.2636 \mathrm{E}-06\end{array}$ & 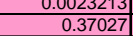 & $\frac{0.000002 / 45}{0.0039976}$ & 4.5605E-06 & | 4.0843 & $\frac{4.53 / 5 \mathrm{E}-0}{0.00002417}$ & $\frac{8.619-10}{2.1178 \mathrm{E}-08}$ & & & $\frac{6.36 / 1 \mathrm{E}-0 C}{4.7775 \mathrm{E}-06}$ & & $\frac{2.9028 \mathrm{E}-00}{0.00021811}$ \\
\hline UPR-200 & $6.3791 \mathrm{E}-09$ & $8.7974 \mathrm{E}-10$ & & $4.2657 \mathrm{E}-11$ & $2.1836 \mathrm{E}-06$ & $1.8852 \mathrm{E}-08$ & $\begin{array}{l}4.50055-00 \\
1.8793 E-11\end{array}$ & $\begin{array}{r}4.000018608 \\
0.000\end{array}$ & $\frac{0.0000241}{1.1549 \mathrm{E}-11}$ & $\begin{array}{c}2.1170-00 \\
1.386 \mathrm{E}-13\end{array}$ & $1.7951 \mathrm{E}-12$ & & & $1.1627 \mathrm{E}-10$ & \\
\hline UPR-200-E-75 & 0.0032786 & 0.00031023 & & 0 & 0.11101 & 0.00077913 & $6.7995 \mathrm{E}-06$ & $\frac{0.78668}{0.0000}$ & $\mid \frac{1.14617 \mathrm{E}-06}{7.4617}$ & $3.3225 \mathrm{E}-08$ & $\frac{1.2501-14}{2.2295 \mathrm{E}-06}$ & & $1.7179 \mathrm{E}-0 \mathrm{C}$ & 0.000017919 & |. \\
\hline UPR-20 & 0.000056191 & 0.000010682 & & $4.9242 E-07$ & 0.037018 & 0.00023818 & & 0.21673 & $3.8468 \mathrm{E}-08$ & $2.118 \mathrm{E}-09$ & & & $4.8874 \mathrm{E}-0$ & $1.3435 E-06$ & \begin{tabular}{|l|}
0.000021845 \\
\end{tabular} \\
\hline$=-78$ & $7.0347 E-06$ & 0.000021727 & & $2.6929 \mathrm{E}-06$ & & 0.00084329 & $5.0429 \mathrm{E}-08$ & 1.5089 & 0.00010192 & $1.1018 \mathrm{E}-10$ & $6.8385 \mathrm{E}-10$ & & $6.7314 \mathrm{E}-0 \varepsilon$ & $3.5638 \mathrm{E}-06$ & \begin{tabular}{|l|}
$3.1806 \mathrm{E}-06$ \\
\end{tabular} \\
\hline 0-E-79 & 0.0025364 & 0.001061 & & 0.000041895 & 3.7901 & 0.012495 & 0.000017488 & 16.458 & 0.00001083 & $2.0381 \mathrm{E}-07$ & $2.7991 \mathrm{E}-06$ & & $1.7366 \mathrm{E}-0 \mathrm{t}$ & 0.00010805 & 0.000079067 \\
\hline $0-E-80$ & 0.00017455 & 0.000032776 & & $1.4929 \mathrm{E}-06$ & 0.11525 & 0.00073021 & $3.1909 \mathrm{E}-07$ & 0.66674 & $1.1817 \mathrm{E}-07$ & $4 \mathrm{E}-09$ & & & $1.4916 \mathrm{E}-0 \mathrm{C}$ & $4.1268 \mathrm{E}-06$ & 0.000067167 \\
\hline UPR-20 & 3.196 & $\begin{array}{r}0.14547 \\
\end{array}$ & & 0.000065922 & 31.604 & 0.027434 & 0.02384 & 38.405 & 0.00011686 & & 0.00024636 & 0.01130 & & 0.00018228 & 0.0029785 \\
\hline UPR-2 & 0.027036 & 0.037135 & & 0.004437 & 10.491 & 1.4161 & 0.00083909 & 66.009 & 0.0017985 & 2.038 & $3.3523 \mathrm{E}-06$ & 0.0001574 & $4.5259 \mathrm{E}-0$ & 0000 & \\
\hline UPR-200-E-84 & 0.0093818 & $3.9206 \mathrm{E}-08$ & & $3.8513 \mathrm{E}-09$ & 0.000051556 & $1.2081 \mathrm{E}-06$ & $3.7958 \mathrm{E}-06$ & 0.000020418 & $2.9476 \mathrm{E}-09$ & & $1.4949 \mathrm{E}-09$ & & $1.0881 \mathrm{E}-0 \varepsilon$ & $5.1668 \mathrm{E}-06$ & $5.1446 \mathrm{E}-07$ \\
\hline UPR-200-E-85 & 0.0068072 & 0.0093565 & & 0.0011172 & 2.6408 & 0.35647 & 0.00021125 & $\begin{array}{r}16.607 \\
\end{array}$ & 0.0004522 & $5.12 \mathrm{~s}$ & $8.4307 \mathrm{E}-07$ & 0.00003957 & $1.1389 \mathrm{E}-06$ & 0.0011618 & 0.000052844 \\
\hline UPR-2 & 0.10057 & 0.13026 & & & 72.533 & 4.9155 & & 8835.2 & 0.0119 & & $E-06$ & 0.0002690 & & & 0.0014069 \\
\hline & $6.4164 \mathrm{E}-10$ & 0.000010221 & & & 0.00070962 & $9.2854 \mathrm{E}-07$ & & 0.00084458 & 6.639E-07 & & 8E-06 & & & 0.000011123 & 1.80 \\
\hline UPR-2 & & 0.0098452 & & 0.00044623 & $\begin{array}{r}44.437 \\
\end{array}$ & 0.15543 & 0.00019938 & 213.05 & 0.00010073 & & $7.0721 \mathrm{E}-08$ & & 0.000018855 & 0.0012335 & 5309 \\
\hline $\begin{array}{l}-100 \\
101\end{array}$ & 0.0081987 & 0.00077567 & & 0.000025619 & 0.27754 & 0.0019477 & 0.000016998 & 1.9665 & 0.000018651 & $8.3055 \mathrm{E}-08$ & $5.5752 \mathrm{E}-06$ & 152050 & $4.2933 \mathrm{E}-0 \mathrm{G}$ & 0.000044802 & 0.00019707 \\
\hline $\begin{array}{l}\text { UPR-2 } \\
\text { UPR-2 }\end{array}$ & 0.0099017 & & & & 0 & 0.00013371 & & & & 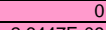 & & & 0.000056486 & 0 & 0.0025787 \\
\hline UPR-20 & $5.5419 \mathrm{E}-08$ & 0.000016358 & & $7.4475 \mathrm{E}-07$ & 0.0012752 & $1.5084 \mathrm{E}-06$ & & 0.0015408 & 4.0343E-06 & $2.6447 \mathrm{E}-09$ & & & $\begin{array}{l}7.7476 \mathrm{E}-0 \mathrm{~S} \\
5.205 .11\end{array}$ & 0.000018407 & $1.7864 E-07$ \\
\hline$\frac{R-200-W-103}{R-200-W(2)}$ & 0 & 52154 E- 0 ( & & $20594=0$ & & 0000061401 & $85986 \mathrm{E}-08$ & & $531055-08$ & 1002500 & $\begin{array}{l}4.6428 E-14 \\
17362508\end{array}$ & & 5.389E-12 & $\begin{array}{r}0.0038475 \\
52315507\end{array}$ & $\begin{array}{l}1.0954 E-10 \\
2.0270-07\end{array}$ \\
\hline$\frac{R-200-W-12}{R-200-W-127}$ & $\frac{0.000012467}{0.0013406}$ & $5.2154 \mathrm{E}-06$ & & $2.0594 \mathrm{E}-07$ & $\mid$\begin{tabular}{|c|}
0.0186635 \\
$2.568 E-11$
\end{tabular} & $\frac{0.000061401}{0}$ & $8.5986 \mathrm{E}-08$ & $\frac{0.080911}{6.536 \mathrm{E}-11}$ & 5.3195E-08 & $\begin{array}{r}1.002 \mathrm{E}-09 \\
0\end{array}$ & $1.3762 \mathrm{E}-08$ & & $\frac{8.5335 \mathrm{E}-0 \mathrm{-}}{18019 \mathrm{E}-1}$ & $5.3115 \mathrm{E}-07$ & $\begin{array}{l}3.8876 E-07 \\
800025-11\end{array}$ \\
\hline & 0.0013406 & & & $3.0702 E-13$ & $\frac{2.568 \mathrm{E}-11}{6.1195 \mathrm{E}-11}$ & $\frac{0}{17642 \mathrm{E}-11}$ & & $\frac{6.536-11}{6.9861 \mathrm{E}-11}$ & \begin{tabular}{r|}
0 \\
$5.6981 E-14$
\end{tabular} & & \begin{tabular}{r|}
0 \\
$1.8843 \mathrm{E}-13$
\end{tabular} & & & $\frac{1.2322 \mathrm{E}-09}{3.446-08}$ & $\frac{8.0002 E-11}{8.973 E-10}$ \\
\hline D-W-131 & 0.000012928 & $3.5761 E-06$ & & $\begin{array}{ll}1.6203 \mathrm{E}-07 \\
\end{array}$ & $\mid 0.016144$ & 0.00005644 & $7.2389 \mathrm{E}-08$ & $\frac{0.00077348}{0.0778}$ & $\mid$\begin{tabular}{|c|c|c|}
$3.6603 \mathrm{E}-08$ \\
\end{tabular} & 7.611 E-10 & $\frac{1.00455-10}{2.5385-11}$ & & $\frac{2.2445 \mathrm{E}-1 .}{6.8482 \mathrm{E}-0 .}$ & $4.47455-00$ & $\frac{8.9 / 35 \mathrm{E}-10}{3.0973 \mathrm{E}-07}$ \\
\hline UPR- & 0.0068333 & 0.00081226 & & 0.000045064 & 2.019 & 0.021803 & 0.000024875 & 22.28 & 0.000013184 & $1.155 \mathrm{E}-07$ & & & 0.00002605 & 0.00012533 & 0.0011897 \\
\hline & 0.013671 & 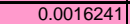 & & 0.000090144 & 4.0382 & & 0.000049755 & 44.551 & 0.00002637 & & & & & 0.00025067 & \\
\hline$N-138$ & & & & & & 0.00044135 & & & & & & $5.0392 \mathrm{E}-0$ & 0.0001864 & & 0.008512 \\
\hline -W-163 & 0.13061 & $5.4369 \mathrm{E}-10$ & & $2.791 \mathrm{E}-11$ & $1.1826 \mathrm{E}-06$ & 0.002275 & $2.5866 \mathrm{E}-07$ & $5.5194 \mathrm{E}-06$ & $9.5513 \mathrm{E}-12$ & $2.9188 \mathrm{E}-12$ & $4.7322 \mathrm{E}-13$ & $8.7359 \mathrm{E}-0 \mathrm{C}$ & & $8.2429 \mathrm{E}-10$ & 0.014716 \\
\hline -W-19 & $2.928 \mathrm{E}-09$ & $8.0978 \mathrm{E}-10$ & & $3.6699 \mathrm{E}-11$ & $3.6555 \mathrm{E}-06$ & 0.000051134 & $1.6398 \mathrm{E}-11$ & $5.8404 \mathrm{E}-06$ & $8.287 \mathrm{E}-12$ & $7.8169 \mathrm{E}-09$ & $1.2116 \mathrm{E}-10$ & 4.1755E & & & $9.5442 \mathrm{E}-06$ \\
\hline & 0.019917 & 0.0037858 & & 0.00017451 & 13.122 & 0.084426 & 0.000037367 & 76.812 & 0.000013634 & $7.5072 E-07$ & & & & & \\
\hline & 0.0031275 & & & & $5.9922 \mathrm{E}-11$ & & & $1.525 \mathrm{E}$ & & & & & & $2.8749 \mathrm{E}-09$ & $1.8382 \mathrm{E}-10$ \\
\hline & 0.040041 & 0.00475 & & 0.00026405 & 11.831 & 0.12 & 0.000145 & 130 & 0.000077221 & $6.7684 \mathrm{E}-07$ & & & & 0.00073415 & 0.0069688 \\
\hline UPR-2C & 0.00022 & 0.0000423 & & $1.9506 \mathrm{E}$ & 0.14666 & & & 0.858 & $1.5231 \mathrm{E}-07$ & $8.3897 \mathrm{E}-09$ & $2017 \div 00$ & & 1.93 & $5.3218 \mathrm{E}-06$ & 086532 \\
\hline & 0.001 & 0.00054618 & & 0.000024761 & 2.4656 & & 0.000011063 & 11.822 & 5.5913E-06 & $1.1632 \mathrm{E}-07$ & $3.9017 \mathrm{E}-09$ & & & 0.000068445 & \\
\hline UPR-200-W-29 & 0.0032232 & 0.00030501 & & 0.000010074 & 0.10915 & 0.006 & 0.000006685 & 0.77346 & 7.3357E-06 & $3.2663 \mathrm{E}-08$ & $2.1919 \mathrm{E}-06$ & 191015 & $\frac{7 E-06}{20-06}$ & 0.000017614 & 0.77477 \\
\hline$\frac{-W-32}{-W-33}$ & $\frac{0.0010793}{8342756}$ & Q9141E-07 & & $\begin{array}{r}0 \\
55009 \mathrm{E}-08\end{array}$ & 0.0024645 & 0.000015547 & & 0.027188 & & & & $1.1191 \mathrm{E}-1 \mathrm{C}$ & & & $\frac{0.00018901}{1.5211-06}$ \\
\hline & $\frac{8.342 / 1-06}{0.027806}$ & $\frac{9.914 t 1-04}{0.0033042}$ & & $\frac{5.500918-08}{0.00018336}$ & $\frac{0.0024645}{8.2156}$ & & $\frac{3.0359 \mathrm{E}-\mathrm{U}}{0.000101}$ & $\frac{0.0218 .686}{90.646}$ & $\frac{1.6091}{0.00005}$ & 469096 & & & & & $\begin{array}{l}1.4521 E-06 \\
0.0018398\end{array}$ \\
\hline & 0.0008 & & & & & $\frac{0.088}{0.0000114}$ & & & & & & $13047 \mathrm{~F}-\mathrm{T}$ & & & \\
\hline & 0.0030156 & 0.0011732 & & 0.000054615 & 0.83363 & $\frac{.0000114}{0.0206}$ & 0.000033149 & 26.126 & $\mid 0.0000387$ & $30853 \mathrm{E}-09$ & $19691 \mathrm{E}-08$ & & $3.3923 \mathrm{E}-07$ & 00001507 & $\begin{array}{l}0.0002204 \\
0.00001594\end{array}$ \\
\hline & & & & & & & & & & & & & & 0.0001501 & $\frac{0.0001594}{3.451 E-14}$ \\
\hline & & & & $6.0305 E-08$ & & 0.00003453 & $7.4072 E-08$ & & $4.1469 \mathrm{E}-08$ & & & & & & \\
\hline UPR-200-W-82 & & & & & 1.198 & & & $\begin{array}{r}.05 \mathrm{E}-10 \\
\end{array}$ & 0 & & & & & $5.7501 \mathrm{E}-09$ & \\
\hline UPR-200-W-87 & $\begin{array}{l}4.8545 \mathrm{E}-09 \\
0.0001529\end{array}$ & \begin{tabular}{|c|}
$5.784 E-10$ \\
0005951
\end{tabular} & & $\begin{array}{l}4.0561 E-11 \\
0.00002779\end{array}$ & $4.0453 E-07$ & $\frac{1.5286 \mathrm{E}-08}{0.08}$ & \begin{tabular}{|c|}
$2.4003 E-11$ \\
$16025-0$
\end{tabular} & 0.000021506 & $2.5771 \mathrm{E}-11$ & $\frac{2.4419 E-15}{15554-12}$ & $\frac{1.5529 \mathrm{E}-14}{0.924 \mathrm{~F}-10}$ & & $\frac{1.9687 \mathrm{E}-1}{1.231 \mathrm{~F}-08}$ & \begin{tabular}{|l|l|}
3 & $6.9892 \mathrm{E}-11$ \\
8
\end{tabular} & $\begin{array}{l}9.086 \mathrm{E}-12 \\
8009-57 \\
\end{array}$ \\
\hline R-200-W-95 & & & & & & & & & & & & & & & \\
\hline
\end{tabular}




\begin{tabular}{|c|c|c|c|c|c|c|c|c|c|c|c|c|c|c|c|}
\hline Site & H3 & C14 & $\mathrm{Cl36}$ & Se79 & Sr90 & Tc99 & 1129 & $\begin{array}{ll}\text { Cs137 } \\
\end{array}$ & Eu152 & Ra226 & Pa231 & U233 & U235 & Np237 & $\begin{array}{ll}\mathrm{U} 234 / 8 \\
\end{array}$ \\
\hline UPR-200-W-96 & $2.0639 \mathrm{E}-08$ & $2.458 \mathrm{E}-09$ & & $1.7243 \mathrm{E}-10$ & $1.7191 \mathrm{E}-06$ & $6.4961 \mathrm{E}-08$ & $1.0202 \mathrm{E}-10$ & 0.000091443 & $1.0951 \mathrm{E}-10$ & & & & $8.3652 \mathrm{E}-13$ & $2.9716 \mathrm{E}-10$ & $3.8604 \mathrm{E}-11$ \\
\hline UPR-200-W-97 & $7.7684 \mathrm{E}-07$ & 0.00001748 & & $7.9583 \mathrm{E}-07$ & 0.008041 & $9.5091 \mathrm{E}-06$ & & 0.0097159 & $1.2934 \mathrm{E}-06$ & $2.8264 \mathrm{E}-09$ & $5.5999 E-07$ & & $2.2253 \mathrm{E}-07$ & $3.9389 \mathrm{E}-06$ & 0.000010151 \\
\hline UPR-200-W-98 & 0.00053446 & 0.00010159 & & & 0.35217 & & $1.0027 E-06$ & & & $2.0141 \mathrm{E}-08$ & & & $4.6484 \mathrm{E}-06$ & 0.000012781 & 0.00020779 \\
\hline UPR-300-1 & & & & $2.4758 \mathrm{E}-06$ & 2.0401 & 0.0014177 & 0.000003041 & 2.1841 & $4.5023 \mathrm{E}-06$ & & & & & 0 & \\
\hline UPR-300-2 & & & & $2.4758 \mathrm{E}-09$ & & $1.4176 \mathrm{E}-06$ & $3.041 \mathrm{E}-09$ & & $2.0893 \mathrm{E}-09$ & & & 0 & & $\underline{0}$ & \\
\hline US Ecology & 67442 & 4627.8 & 3.1853 & & 14498 & $\begin{array}{r}53.143 \\
5.70 ?\end{array}$ & & $\begin{array}{r}36452 \\
\end{array}$ & & 282.79 & 0.001317 & & 30.538 & & 1786.9 \\
\hline WIPP_118-KE-1 & & & & 0.0015878 & 8409.1 & \begin{tabular}{ll|l}
53.793 \\
\end{tabular} & 0.0019471 & 8704.2 & 0.46183 & & & & 0.087495 & 0.154 & 4.1185 \\
\hline WIPP_118-KW-1 & & & & 0.0012839 & 6767.3 & 4.3395 & 0.0015744 & 7038.3 & 0.11567 & & & & 0.053415 & 0.072599 & 2.5143 \\
\hline WIPP_218-E-12B & & & & & 1.3052 & 0.00093039 & & 1.4898 & $3.2804 \mathrm{E}-06$ & & & 0 & & 0 & 0 \\
\hline WIPP_218-W-3A & 0.31686 & 1.5896 & & & 2.4468 & 0.0016572 & & 4.3185 & 0.000007995 & & & 0.24053 & 0.086239 & 0 & 4.418 \\
\hline $\begin{array}{l}\text { WIPP_218-W-WAE } \\
\text { WIPP 218-W-AB }\end{array}$ & & & & $\frac{0.000018565}{0}$ & $\frac{10498}{26291}$ & $\begin{array}{l}0.66692 \\
18593 \\
\end{array}$ & + & $\begin{aligned} 20753 \\
30083 \\
\end{aligned}$ & $\begin{array}{r}0.062166 \\
0.006698\end{array}$ & & & $\begin{array}{r}1.1198 \mathrm{E}-08 \\
72824 \\
\end{array}$ & $\begin{array}{r}0.0000166 \\
038021\end{array}$ & $\begin{array}{r}0 \\
0.15092 \\
\end{array}$ & 0.000682 \\
\hline$\frac{\text { WIP_ } 218-W-W-4 B}{\text { WIPPP } 218-W-4 C}$ & & & & & $\frac{2629.1}{21186}$ & \begin{tabular}{|l|l|}
1.8539 \\
14.788 \\
\end{tabular} & & $\begin{array}{l}\frac{3008.3}{24504} \\
\end{array}$ & $\mid \frac{0.0066998}{0.054968}$ & & & $\begin{array}{l}72.824 \\
7.5676 \\
\end{array}$ & 0.380211 & $\begin{array}{r}0.15592 \\
0.098768\end{array}$ & o. $\frac{0.52425}{1.2337}$ \\
\hline WIPP $234-5 Z$ & & & & & & & & & & & & & & & \\
\hline WIPP_241-Z-361 & & & & & & & & & & & & 0 & 0 & 0 & \\
\hline WIPP_H2-CHTRU-PKGS & 0.16765 & 0.072135 & & 0.0014423 & 5667.7 & 18.142 & 0.00013282 & 245.89 & 0.00088901 & $7.0334 \mathrm{E}-06$ & 0.0006313 & $3.0654 \mathrm{E}-06$ & 0.1274 & 0.056379 & 5.9562 \\
\hline WIPP_H2-RHTRU-PKGS & 0.30894 & $\begin{array}{r}1.0543 \\
\end{array}$ & & & & 156.16 & 0.063167 & 105910 & 17.788 & 0.00026993 & $0.9013 \varepsilon$ & & 0.68042 & 2.3888 & 30.386 \\
\hline WIPP_RMWSF & 0.0082105 & 0.000092528 & & 0.0013183 & 11680 & 69.233 & 0.0021613 & 14262 & 0.020734 & & & 0.087297 & 0.071953 & 0.20743 & 3.6867 \\
\hline Yucca_100-K-42 & 2282.5 & 344.99 & & $\begin{array}{r}43.098 \\
\end{array}$ & 2072100 & 1439.8 & 3.185 & 2812800 & 71.107 & & & & 14.493 & 28.6 & 828.06 \\
\hline Yucca_100-K-43 & & 344.99 & & & 2072100 & 1439.8 & 3.185 & 2812800 & 71.107 & & & 0 & 14.493 & & 828.06 \\
\hline Yucca_218-W-3A & 2.3582 & 55.557 & & 0.010074 & 12570 & 5.6334 & 0.011167 & $\begin{array}{ll}14096 \\
\end{array}$ & 0.051022 & & & 0 & 0.069017 & 0.22061 & 0.028486 \\
\hline 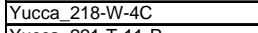 & 5.0308 & 11.251 & & 0.021492 & 10572 & 12.857 & 0.023823 & 30071 & 0.10885 & & & 0 & 0.34393 & 0.40546 & 0.035317 \\
\hline $\begin{array}{l}\text { Yucca_221-T-11-R } \\
\text { Yuc_-20 }\end{array}$ & 1.5297 & 104.38 & & 2.7676 & \begin{tabular}{c|c|}
1060.3 \\
8910000
\end{tabular} & 0.70508 & 0.001398 & 2187.7 & 12.71 & & & 6.9504 & 0.21614 & 1.7949 & 12.35 \\
\hline Yucca_225-B & & & & & 8818600 & & & 21008000 & & & & 0 & & 0 & 0 \\
\hline Yucca 4843 & 22.36 & 1367.6 & & $\begin{array}{l}0.79807 \\
27171 \\
\end{array}$ & 568840 & \begin{tabular}{ll|l}
472.82 \\
36779
\end{tabular} & $\begin{array}{ll}0.93723 \\
21010\end{array}$ & 1617700 & 3.8396 & $\frac{0}{0}$ & & 0 & 0.9159 & 32.026 & 34.099 \\
\hline $\begin{array}{l}\text { YUCCA_H2-HLW-CANISTER } \\
\text { YUCCA RMWSF }\end{array}$ & & $\frac{0}{0}$ & & $\begin{aligned} 2.7471 \\
0\end{aligned}$ & $\frac{18601000}{1139600}$ & 3677.8 & \begin{tabular}{r|r|}
2.1918 \\
\end{tabular} & $\frac{200900000}{164000}$ & 243.46 & $\frac{0.010545}{0}$ & 3.1109 & 692.86 & 7.9052 & $\frac{78.026}{0}$ & $\begin{aligned} 368.62 \\
0\end{aligned}$ \\
\hline $\begin{array}{l}\text { YUCCA_RMWSF } \\
\text { All Sites }\end{array}$ & 150790 & \begin{tabular}{r|r}
0 \\
56130
\end{tabular} & $\frac{0}{348.37}$ & $\begin{aligned} 0 \\
184.88 \\
\end{aligned}$ & $\frac{1139600}{35716000}$ & 31323 & \begin{tabular}{r|}
0 \\
65.38 \\
\end{tabular} & $\frac{1640900}{51485000}$ & \begin{tabular}{r|r|}
0 & 0 \\
737.08
\end{tabular} & \begin{tabular}{r|}
0 \\
694.48 \\
\end{tabular} & 6.1645 & 954.55 & $\begin{array}{l}109.57 \\
\end{array}$ & $\frac{0}{273.66}$ & $\begin{aligned} 5627.3 \\
\end{aligned}$ \\
\hline Nonzero sites & 547 & 545 & 16 & 528 & 671 & \begin{tabular}{r|}
562 \\
\end{tabular} & 529 & 633 & 598 & $\begin{array}{r}412 \\
412\end{array}$ & $\frac{1.4043}{423}$ & 352 & $\frac{1}{602}$ & 523 & 626 \\
\hline
\end{tabular}




\section{Appendix G}

Best Estimate Inventory - Cumulative in 2070 


\section{Appendix G}

\section{Best Estimate Inventory - Cumulative in 2070}

This appendix presents the best-estimate inventory on December 31, 2070. The inventory input to the simulation is a waste site/year/analyte data file and is quite large because simulations can involve up to 690 waste sites, over 50 years of nuclear materials operations, and up to 14 analytes. The cumulative and decay corrected inventory discharged and disposed by a given date, in this case December 31, 2070, is more readily displayed. When acquiring inventory data and estimates, one often finds or is provided a best-estimate value without regard to its uncertainty distribution. In the case of the stochastic Hanford Soil Inventory Model (SIM) results, the best-estimate is the mean. However, in all other cases the single value found or provided is simply interpreted as the best-estimate. The inventory compilation shown here is the best-estimate value for each waste site and analyte. This inventory was taken from the 'By_Site_2070' tab of the 'Tables_Best_2005_11_17_Inv-Data-Package.xls' file.

The best-estimate inventory shown here is a post-processed file that derives from the waste site/year/ analyte file used to drive the Hanford assessment simulation. The waste site /year/analyte file is created by the INVENTORY code when it applies the uncertainty rules described in Section 6 to the 'disposal action file' of 'daf' created by INPROC. The INPROC code applies the fill-in and surrogate rules described in Section 4 to the inventory data files described in Section 5. The input file for INPROC execution is 'inproc-input_2005-11-09_DCR-0024.csv' and it is under configuration management and maintained on the SAC Windows File server at $\backslash$ sac.pnl.gov\shareldata $\backslash$ rev.1 $\backslash$ inventory $\backslash$ The 'Tables_Best...' and the 'inproc-input...' files are attached as an electronic appendix. In addition the output of the INPROC code for reference case A, (i.e., CA_Ref_A.daf), which is the basis for the best-estimate tables, is also included in the electronic appendix.

The background for table entries has been color coded to indicate the type or source of the data; Hanford SIM result, Hanford Tank Waste Operation Simulator (HTWOS) model result, record, estimated by fill-in rule, and estimated by a surrogate rule, or some combination. A key is provided at the bottom of the table.

While assembling the inventory, every effort was made to be consistent with inventories used in performance assessments being prepared for the single-shell tanks and the integrated disposal facility. Near perfect consistency was achieved by using the same simulation by the HTWOS model (Kirkbride et al. 2005). However, Kirkbride et al. (2005) shows a radium-226 inventory in tank 241-C-106 of 416 curies, decay correct to January 1, 2004. Tank 241-C-106 has been cleaned out and the HTWOS model simply used the Best Basis Inventory (BBI) for this tank as its residual. However, the BBI inventory for radium-226 was in error and has been updated to $1.39 \mathrm{E}-03 \mathrm{Ci}$, and that value is now in the draft performance assessment supporting the closure of single-shell tanks. This inconsistency was discovered during peer review of this document, and the updated value has not been promulgated into this inventory for use in Hanford assessments.

Kirkbride RA, PJ Certa, TM Hohl, AM Johnson, and RS Wittman. 2005. Hanford Tank Waste Operations Simulator Model Data Package for the Development Run for the Refined Target Case. RPP-RPT-23412, Revision 0A, CH2M HILL Hanford Group, Inc., Richland, Washington. 
Inventory by site for waste form "All_Types" at the year 2070

\begin{tabular}{|c|c|c|c|c|c|c|c|c|c|c|c|c|c|c|c|}
\hline Site & H3 & C14 & $\mathrm{Cl} 36$ & Se79 & Sr90 & Tc99 & 1129 & Cs137 & Eu152 & Ra226 & Pa231 & U233 & U235 & Np237 & U234/8 \\
\hline & & & & & & & & & & & & & & & \\
\hline $\begin{array}{l}\text { Sill sites } \\
\text { All sites }\end{array}$ & $\frac{\mathrm{H} 3}{27502.53195}$ & \begin{tabular}{|c|} 
C14 \\
56324.49949 \\
\end{tabular} & $\begin{array}{c}\text { CI36 } \\
348.384603 \\
\end{array}$ & \begin{tabular}{|c|} 
Se79 \\
184.8745118 \\
\end{tabular} & \begin{tabular}{|c|} 
Sr90 \\
15374737.46 \\
\end{tabular} & \begin{tabular}{|c|} 
Tc99 \\
31321.24268 \\
\end{tabular} & $\frac{\mid 1129}{65.51366761}$ & $\begin{array}{l}\frac{\text { C15137 }}{2297738.17} \\
\mid\end{array}$ & $\frac{\text { Eu152 }}{122.8828584}$ & \begin{tabular}{|l|} 
Ra226 \\
718.7304906 \\
\end{tabular} & \begin{tabular}{|l|} 
Pa2231 \\
5.159929073
\end{tabular} & 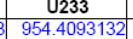 & $\frac{U 235}{109.605882}$ & $\frac{\mathrm{N} \text { Np237 }}{273.6566098}$ & $\frac{U 234 / 8}{5629.483141}$ \\
\hline Offsite transfers - WIPP, Yucca & 641.617491 & 2222..018522 & & 2.62282746 & 4494148.81 & 7367.702737 & 9.60440062 & 22409299.89 & 70.16870199 & 0.010658798 & 4.00994087 & 783.0159861 & 40.1564356 & 172.798743 & 2124.091135 \\
\hline & & & $0.00 \%$ & $50.10 \%$ & & $23.52 \%$ & & $97.53 \%$ & $57.10 \%$ & & $65.10 \%$ & & & $63.14 \%$ & $37.73 \%$ \\
\hline US Ecology & 15869 & 5040.7 & 3.2281 & & 7429 & & & 16268 & 32.858 & 313.24 & 0.001316 & & & & 1789.1 \\
\hline & $57.70 \%$ & & $0.93 \%$ & $0.00 \%$ & $0.05 \%$ & & & $0.07 \%$ & & $43.58 \%$ & $0.02 \%$ & $0.00 \%$ & & & $31.78 \%$ \\
\hline All onsite DOE waste & 10991.91446 & 49061.78096 & & 2.25168 & & 23898.45594 & 94126699 & 551570.276 & 19.85615645 & 405.4798318 & B 2.148672203 & 1.3933271 & 38.87344 & 00.8578668 & 1716.292006 \\
\hline & $39.97 \%$ & $87.11 \%$ & $99.07 \%$ & $49.90 \%$ & $5.68 \%$ & $76.30 \%$ & $76.23 \%$ & $2.40 \%$ & $16.16 \%$ & $56.42 \%$ & $34.88 \%$ & $17.96 \%$ & $35.47 \%$ & $36.86 \%$ & $30.49 \%$ \\
\hline DF only & 15.724056 & 792.3607 & 0.00013071 & .30500544 & 16362.7558 & 22737.00348 & 40.5113583 & 154316.2285 & 444415129 & 3798 & & & 42028 & & 8.35526 \\
\hline & & & & & & & & & & & & & & & $7 \%$ \\
\hline iver $\mathrm{Cc}$ & 75.581149 & 47559.50 & & 1596 & & 33 & 64 & & 88 & $8.06301 \mathrm{E}-05$ & 0.00032884 & 19.659 & 43 & .042454772 & 997 \\
\hline ncludi & 19.79 & $96.94 \%$ & $99.94 \%$ & $0.02 \%$ & $0.37 \%$ & $0.15 \%$ & $0.11 \%$ & $0.78 \%$ & $64.92 \%$ & $0.00 \%$ & $0.02 \%$ & $69.82 \%$ & 6.8 & $0.04 \%$ & $6 \%$ \\
\hline CP - Other "218" waste sites & 5123.39277 & 505.648467 & 22337202 & 558165446 & 74211.7239 & 259.1605277 & 1.137365 & 260271 & $23481 \mathrm{~s}$ & & & 0.5256 & & 74 & \\
\hline & & & & & & & & & & $0.00 \%$ & $0.00 \%$ & & & & \\
\hline CP - "216" waste sites & 3672.243341 & 191.2413 & & 827369 & 3556.6 & 108 & 4.548179123 & 9693.817603 & 0.082597046 & 0.009687972 & 0.08590767 & 22.488 & 2.2184 & 53.37013883 & 100.6171799 \\
\hline & & & $0.00 \%$ & & & & & & & & $4.00 \%$ & & & & $5.86 \%$ \\
\hline CP - facilities & 1.4574 & 0.008 & & 0.0 & & & 6694 & 0552. & 32 & & & & & & \\
\hline & & & $0.00 \%$ & & & & & & & & & & & & $1.74 \%$ \\
\hline CP - "200" waste sites & 0.383476 & 3.05351 & & 0.014 & 5 & 5.380 & 0.652563 & 457 & 0.0231 & 4.4070 & 0.001080381 & 10.01850 & 0.021 & 0.011967936 & 70856 \\
\hline CP - UPR waste sites & $\begin{array}{r}0.06 \\
0.5457574\end{array}$ & 0.438544 & & $\begin{array}{r}0.02 \% \\
0.032386981\end{array}$ & $\begin{array}{r}0.58 \% \\
105.8268197\end{array}$ & $\begin{array}{r}0.02 \% \\
10.29649958\end{array}$ & 30181 & 382.84. & $\begin{array}{r}0.12 \% \\
003129801\end{array}$ & $\begin{array}{r}0.00 \% \\
7.76338 \mathrm{E}-06\end{array}$ & $\begin{array}{r}0.05 \% \\
0.000368871\end{array}$ & $\begin{array}{rr}0 & 0.01 \% \\
1 & 0.012098516\end{array}$ & $\begin{array}{r}0.0 \\
0.001388\end{array}$ & $\begin{array}{r}0.01 \\
0.0442354\end{array}$ & $\begin{array}{r}0.06 \% \\
0.063438694\end{array}$ \\
\hline & & & $0.00 \%$ & & & & & & & & & & & 0.04 & $0.00 \%$ \\
\hline CP - tank "241" waste sites & 2.58651 & 12.52929 & & 774 & & & 23839 & 53488.6 & & & 0.118 & $\begin{array}{ll}4 & 12.794\end{array}$ & & 3.560560 & 40141 \\
\hline & & & $0.00 \%$ & & & & & & & & & & & & \\
\hline Subtotal onsite DOE waste & 10991.9 & 49061.7 & 345.15 & & & & & & & & & & & & \\
\hline & 10991.91446 & & & & & & & & & & & & & 678668 & 92 \\
\hline Analyte & $\mathrm{H} 3$ & $\mathrm{c}$ & $\mathrm{Cl} 136$ & & & & & & & & & & & & 8 \\
\hline SIM Data & & 195. & & & & & 4.72 & & & & & & & & 2.4063 \\
\hline & & & $0.00 \%$ & & & & & & & & & & & & \\
\hline HTWOS Data & 229.2363 & 801.1704 & & 92.26 & & & & & & & & & & & 433.4033 \\
\hline Record Data & & $\begin{array}{r}1.42 \% \\
5525623\end{array}$ & $\begin{array}{r}0.00 \% \\
348849\end{array}$ & & & & & & & & 98 & & & & \\
\hline Record Data & $\begin{array}{r}23795.06 \\
86.52 \%\end{array}$ & $\begin{array}{r}55256.23 \\
98.10 \%\end{array}$ & $\begin{array}{l}348.3849 \\
1000\end{array}$ & $\begin{array}{l}89.80 \\
48.5\end{array}$ & & & & & & $\begin{array}{r}313.2424 \\
4358 \%\end{array}$ & $\begin{array}{l}4.001315997 \\
0.02 \%\end{array}$ & & & & $\begin{array}{l}041.401 \\
89.55 \%\end{array}$ \\
\hline Estimated Data & & 30.72702 & & 0.6436 & & 23.7 & & & & & & & & & $1.28093 \mathrm{E}-05$ \\
\hline & & & & & & & & & & & & & & & \\
\hline Surrogate Data & & & & 0776 & & & 0.008 & & & -06 & & & & .008197639 & 12.27392 \\
\hline ( & $\begin{array}{r}0.10 \% \\
27502.24 \\
\end{array}$ & $\begin{array}{r}0.07 \% \\
56324.6\end{array}$ & $\begin{array}{r}0.00 \% \\
348.0849 \\
\end{array}$ & $\begin{array}{r}0.00 \% \\
184.874 \\
\end{array}$ & $\begin{array}{r}0.01 \% \\
15374720\end{array}$ & $\begin{array}{c}0.01 \% \\
31321.14\end{array}$ & $\begin{array}{r}0.01 \% \\
65.51318 \\
\end{array}$ & $\begin{array}{r}0.01 \% \\
22977200\end{array}$ & $\begin{array}{r}4.61 \% \\
122.8826 \\
\end{array}$ & $\begin{array}{r}\frac{0.00 \%}{718.7372} \\
\end{array}$ & $\begin{array}{r}0.02 \% \\
6.15993 \\
\end{array}$ & $\begin{array}{r}0.14 \% \\
954.4077\end{array}$ & $\begin{array}{r}0.24 \% \\
109.6046\end{array}$ & $\begin{array}{r}0.00 \% \\
273.6567\end{array}$ & $\begin{array}{r}0.22 \% \\
5629.484\end{array}$ \\
\hline
\end{tabular}

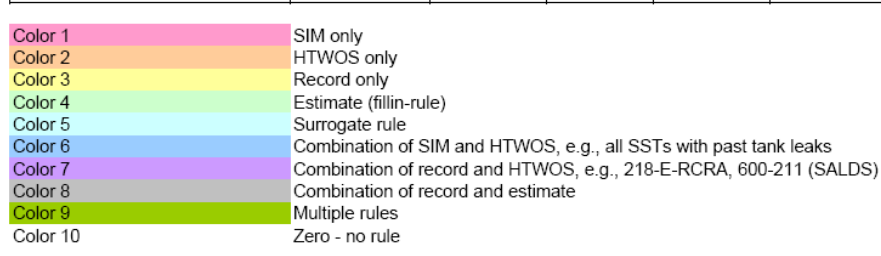


Inventory by site for waste form "All_Types" at the year 2070

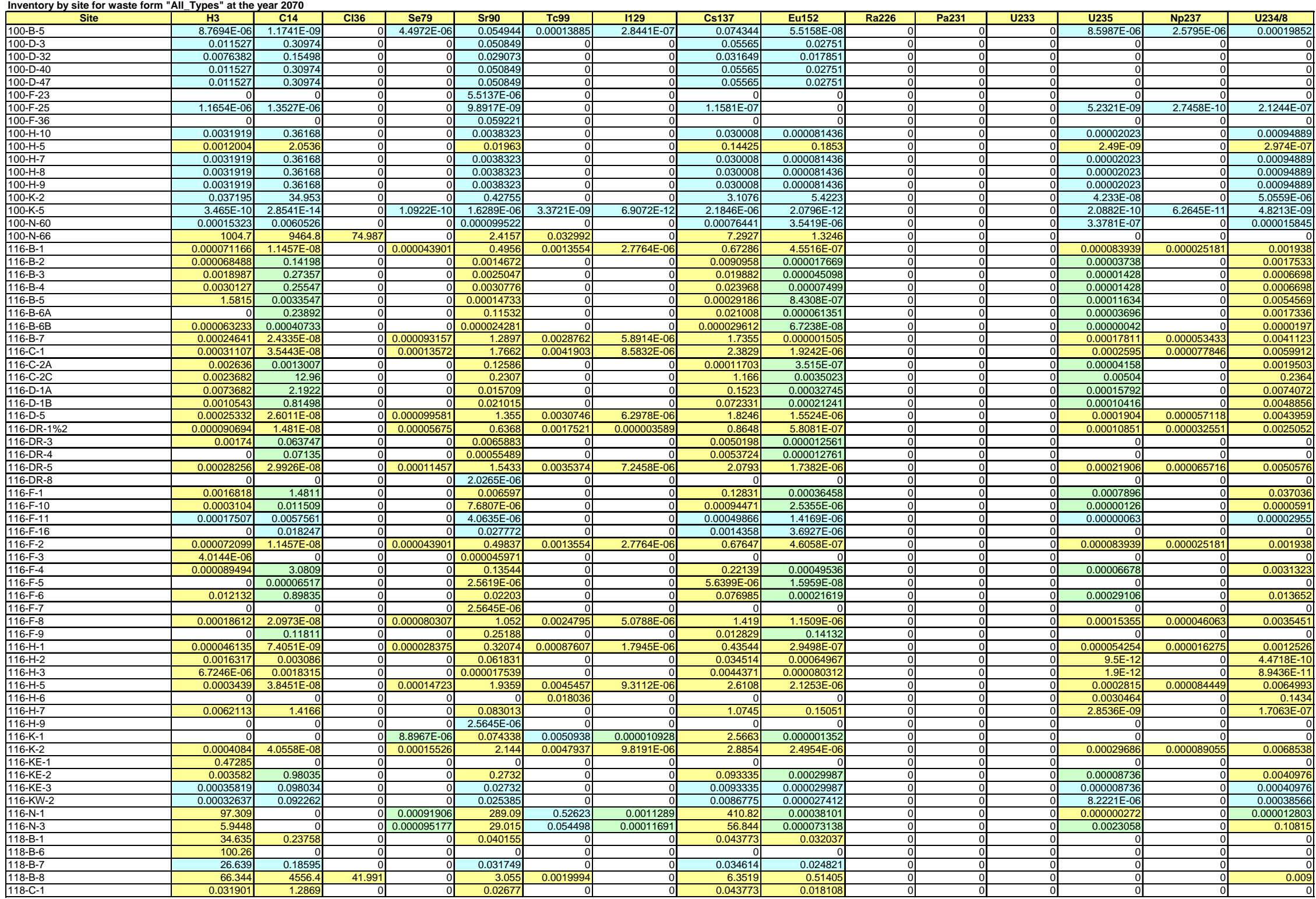


Inventory by site for waste form "All_Types" at the year 2070

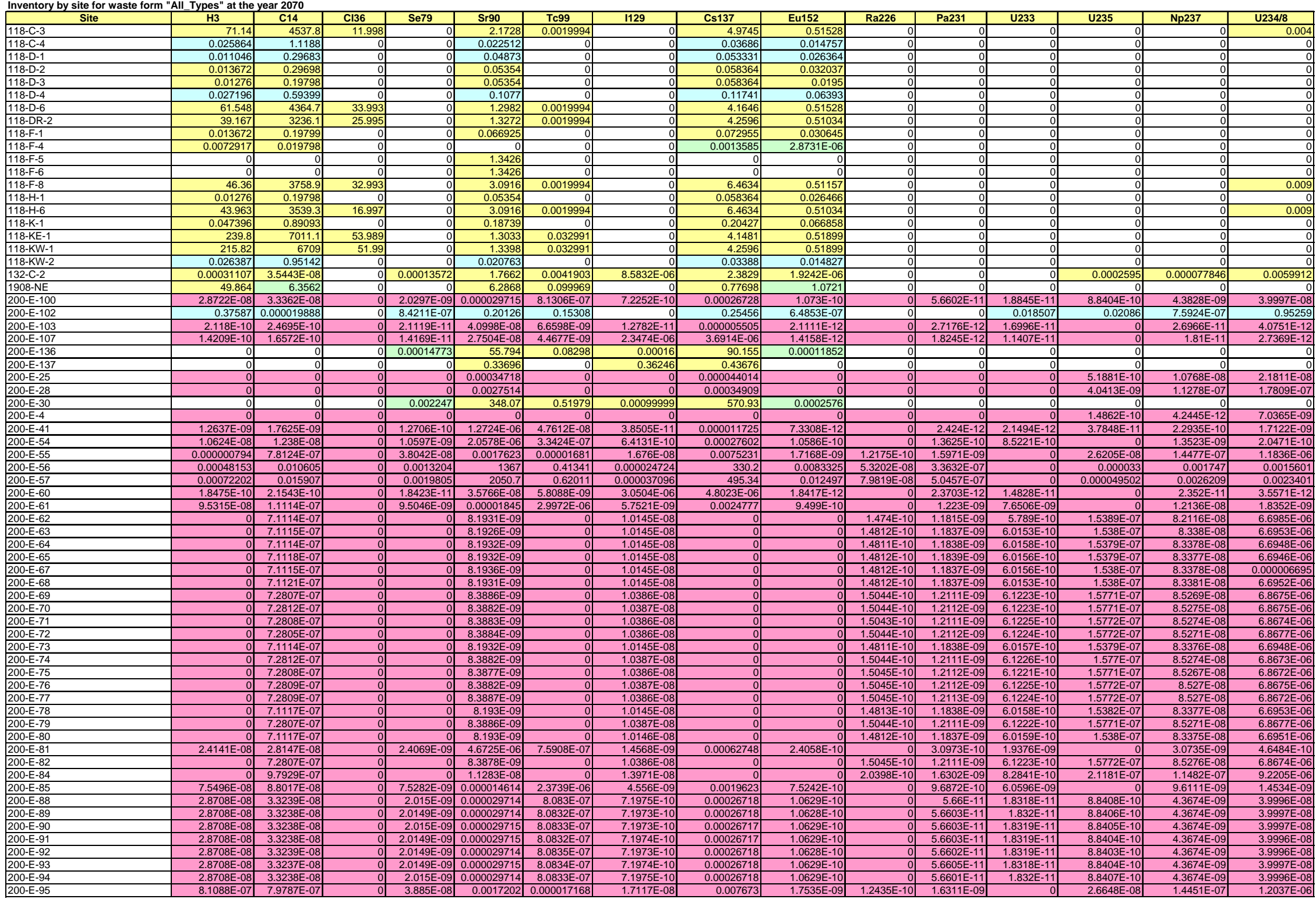


Inventory by site for waste form "All_Types" at the year 2070
Site

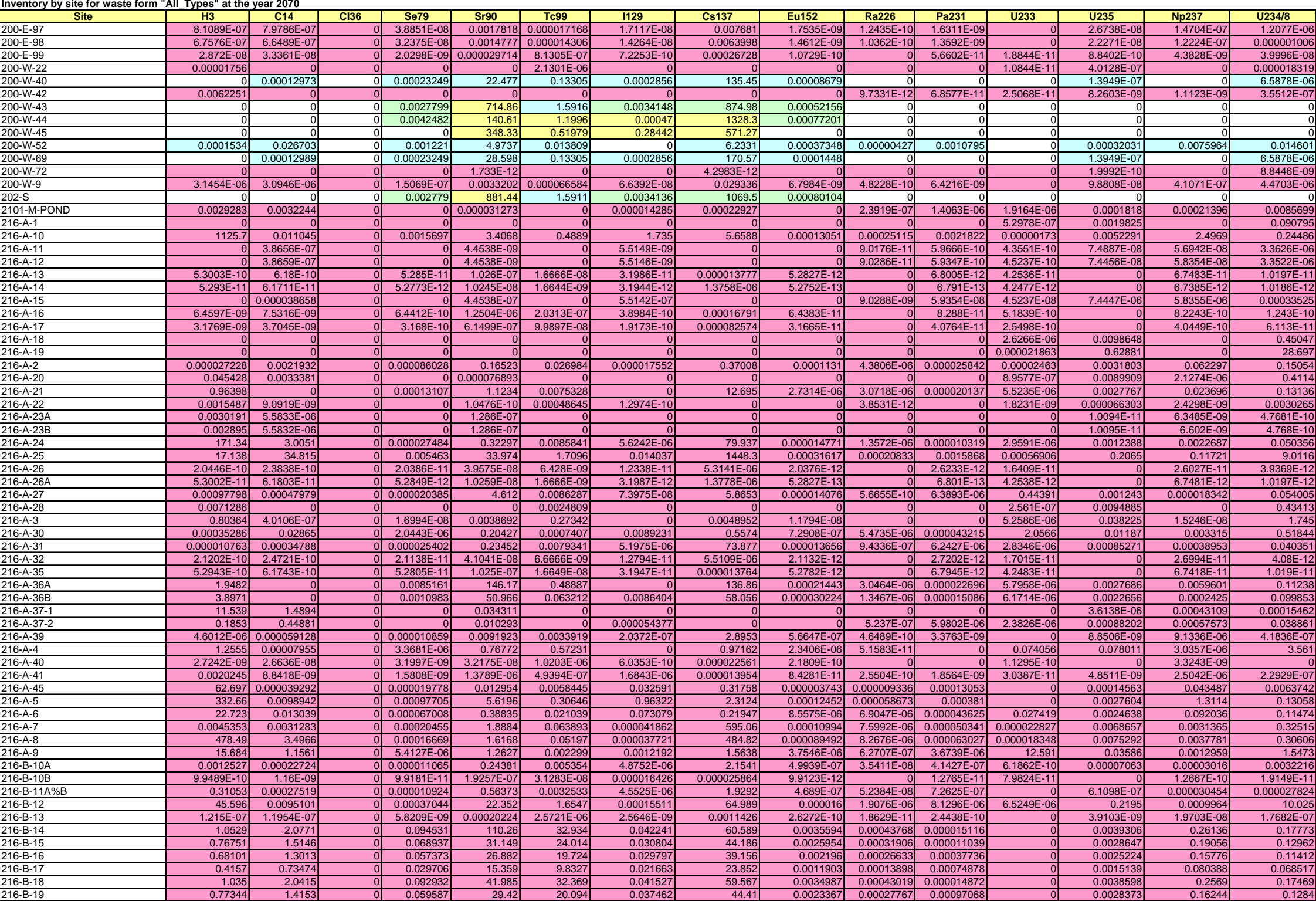


Inventory by site for waste form "All_Types" at the year 2070

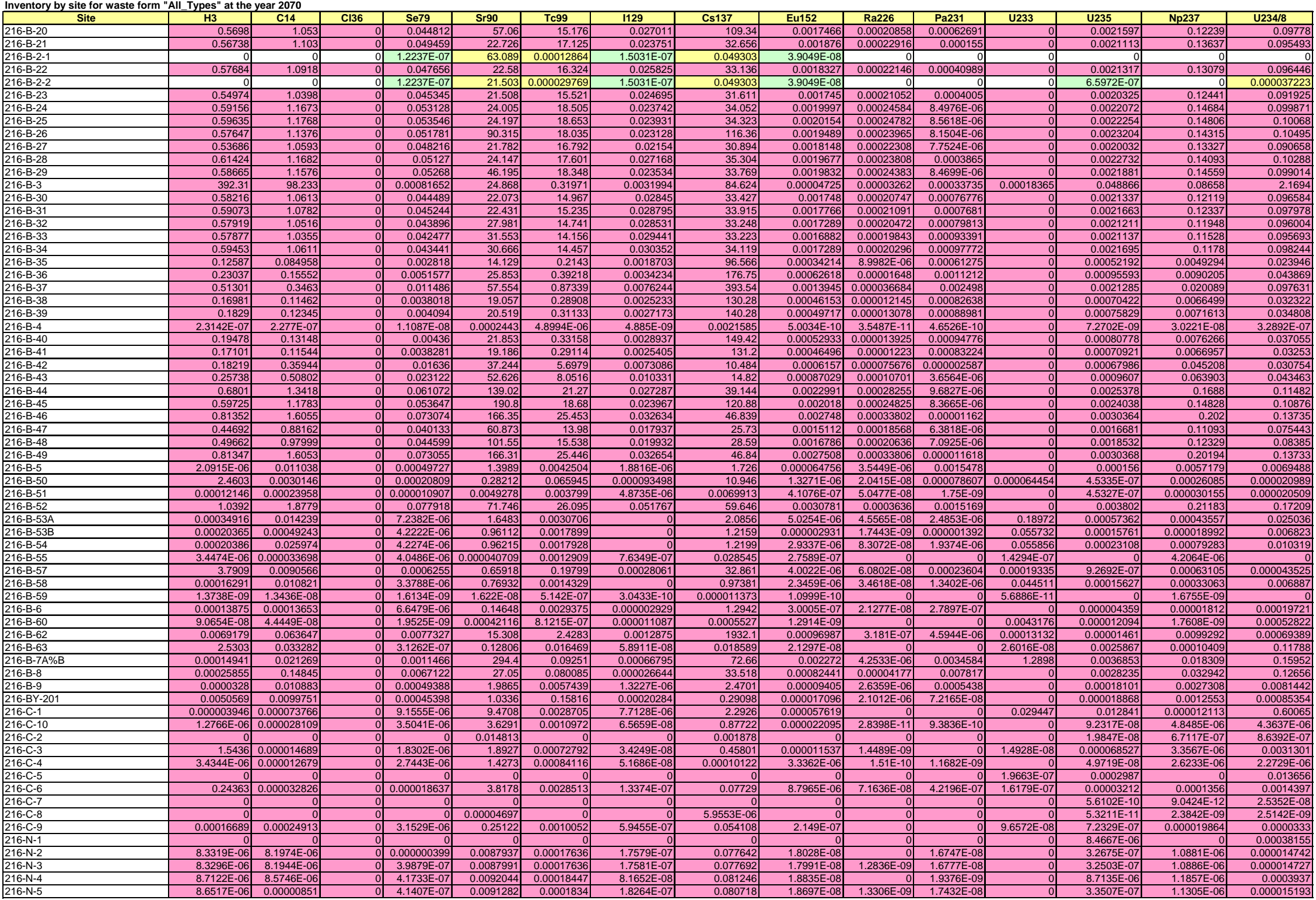


\begin{tabular}{|c|c|c|} 
Inventory by site for waste form "All_Types" at the year 2070 \\
\hline Site & H3 & C14 \\
\hline
\end{tabular}

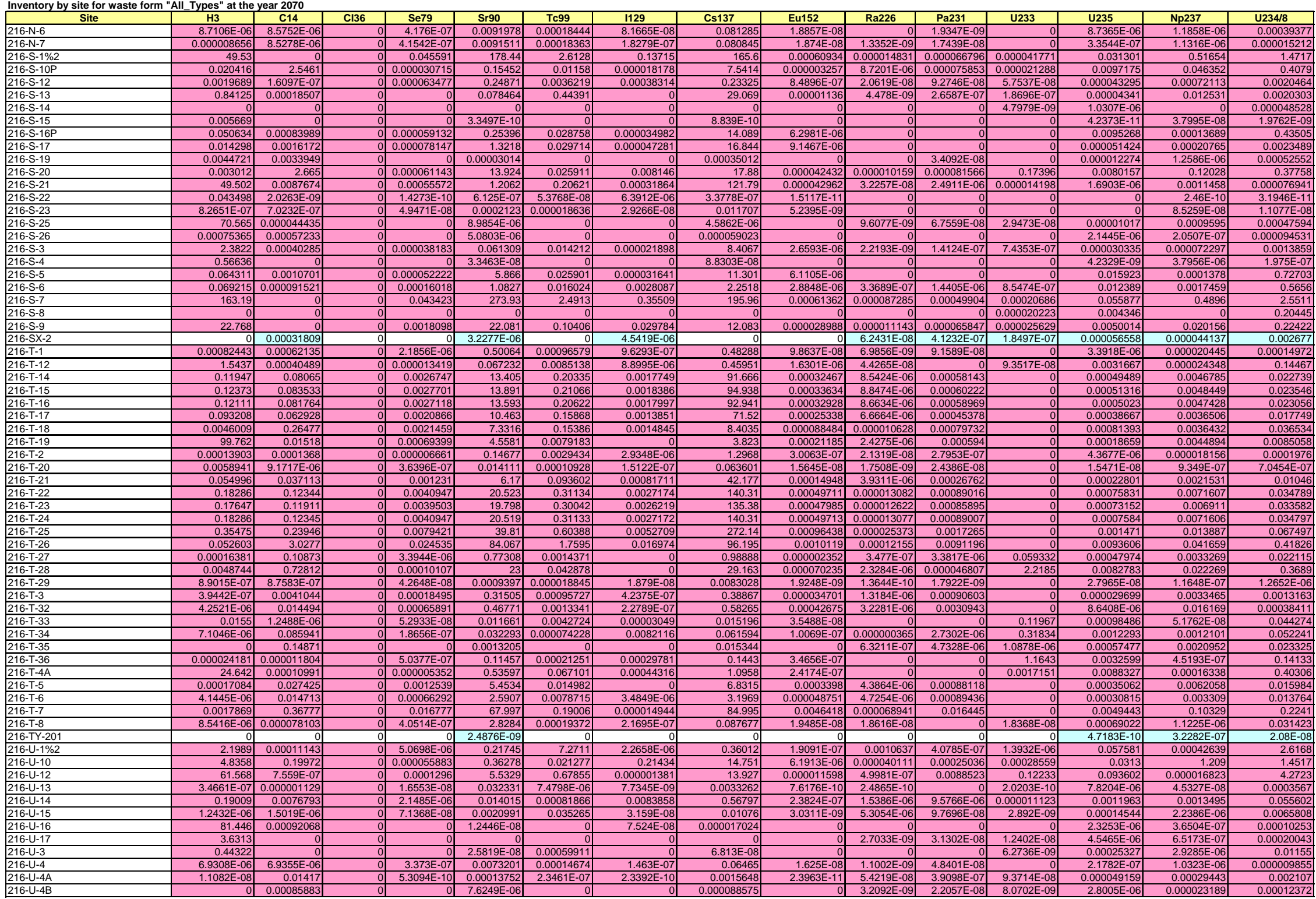


Inventory by site for waste form "All_Types" at the year 2070

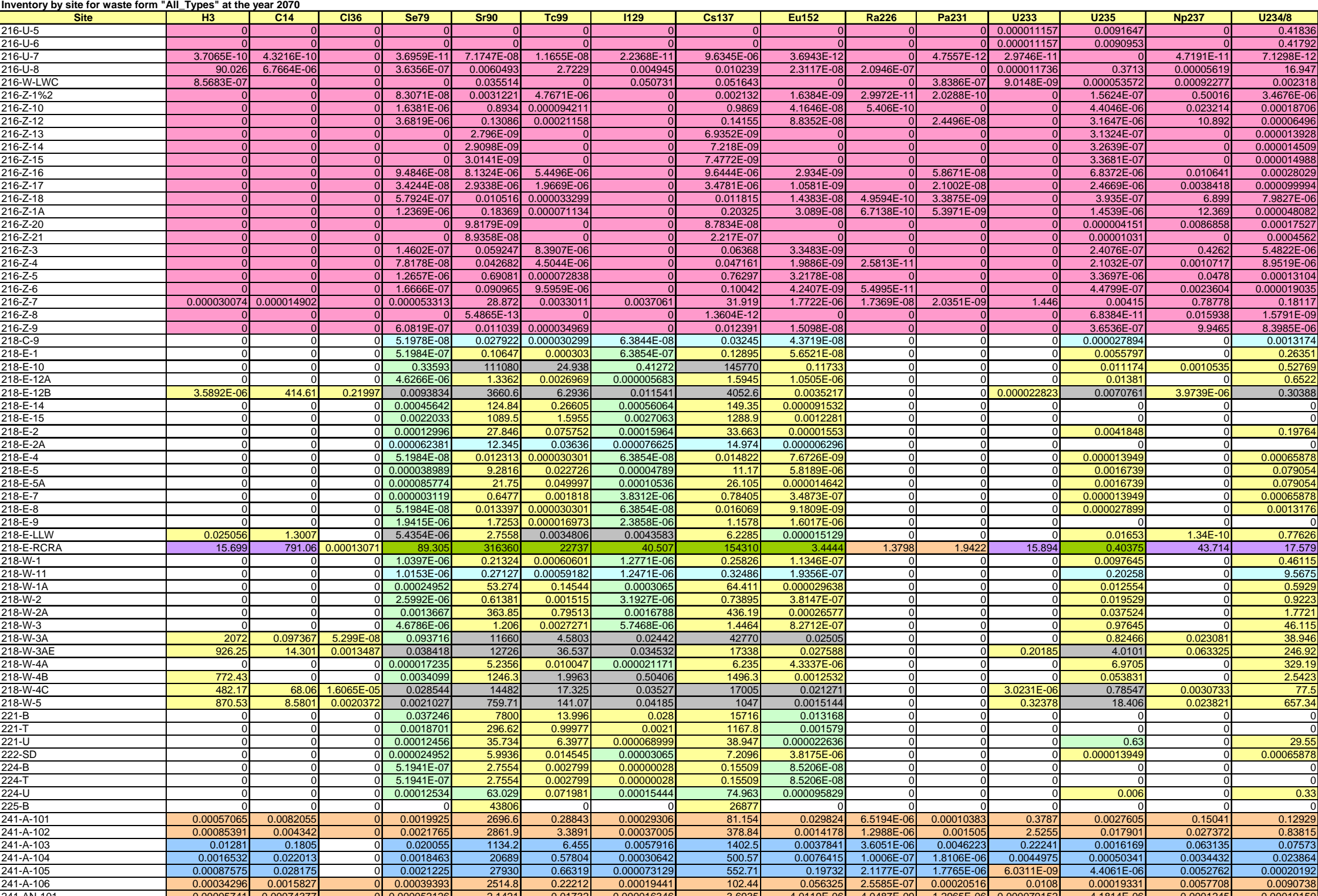


Inventory by site for waste form "All_Types" at the year 2070
Site

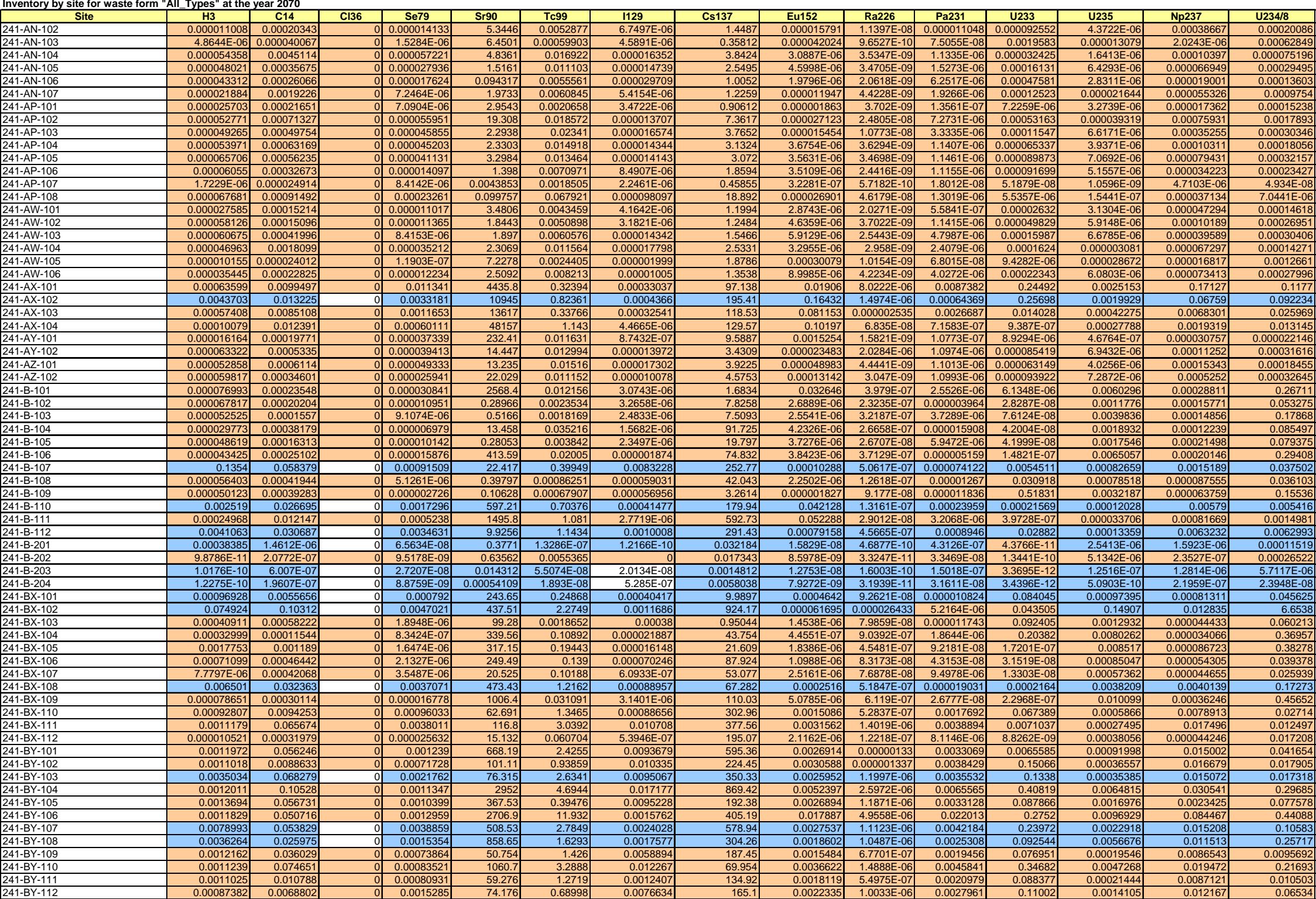


Inventory by site for waste form "All_ Types" at the year 2070

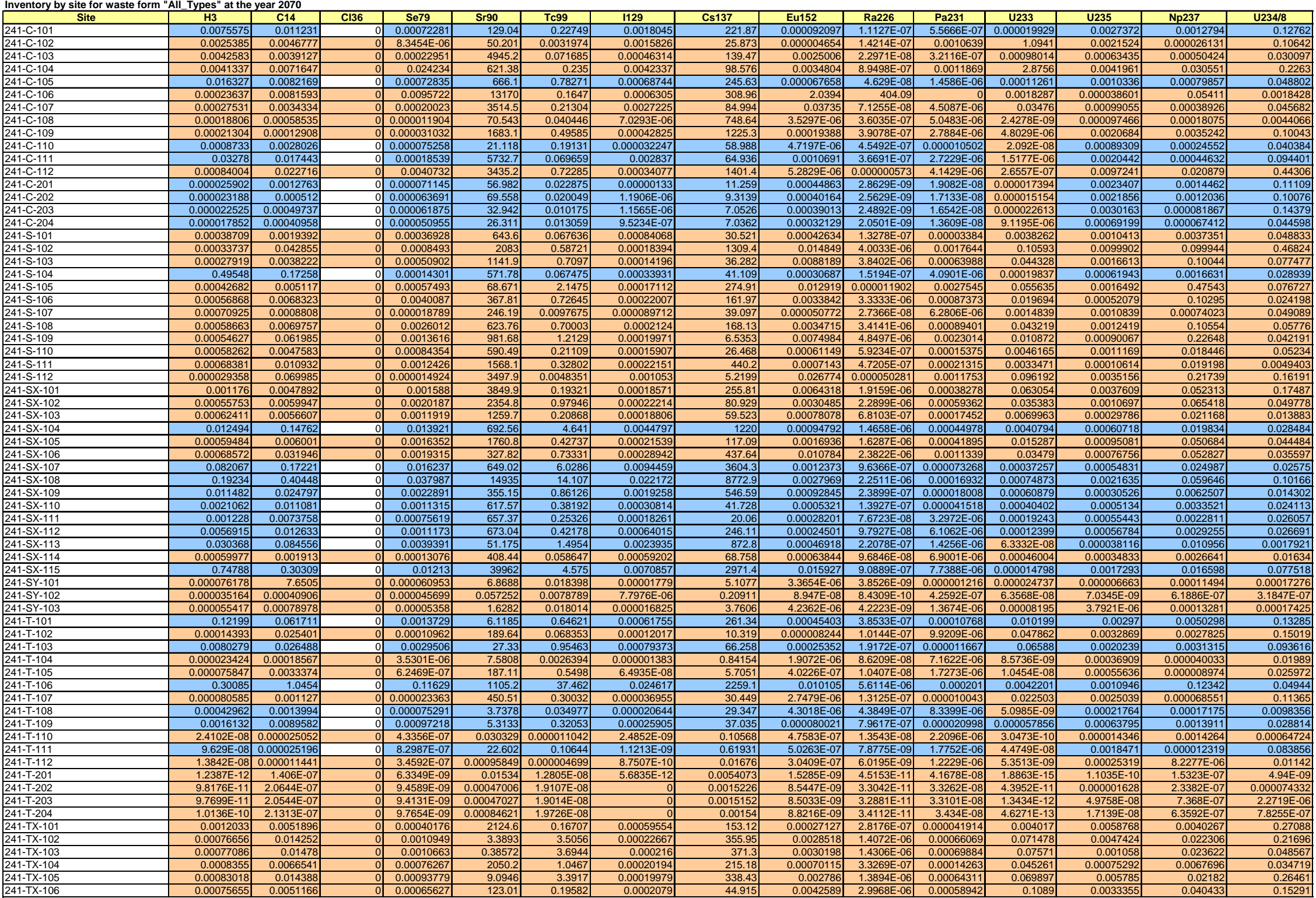




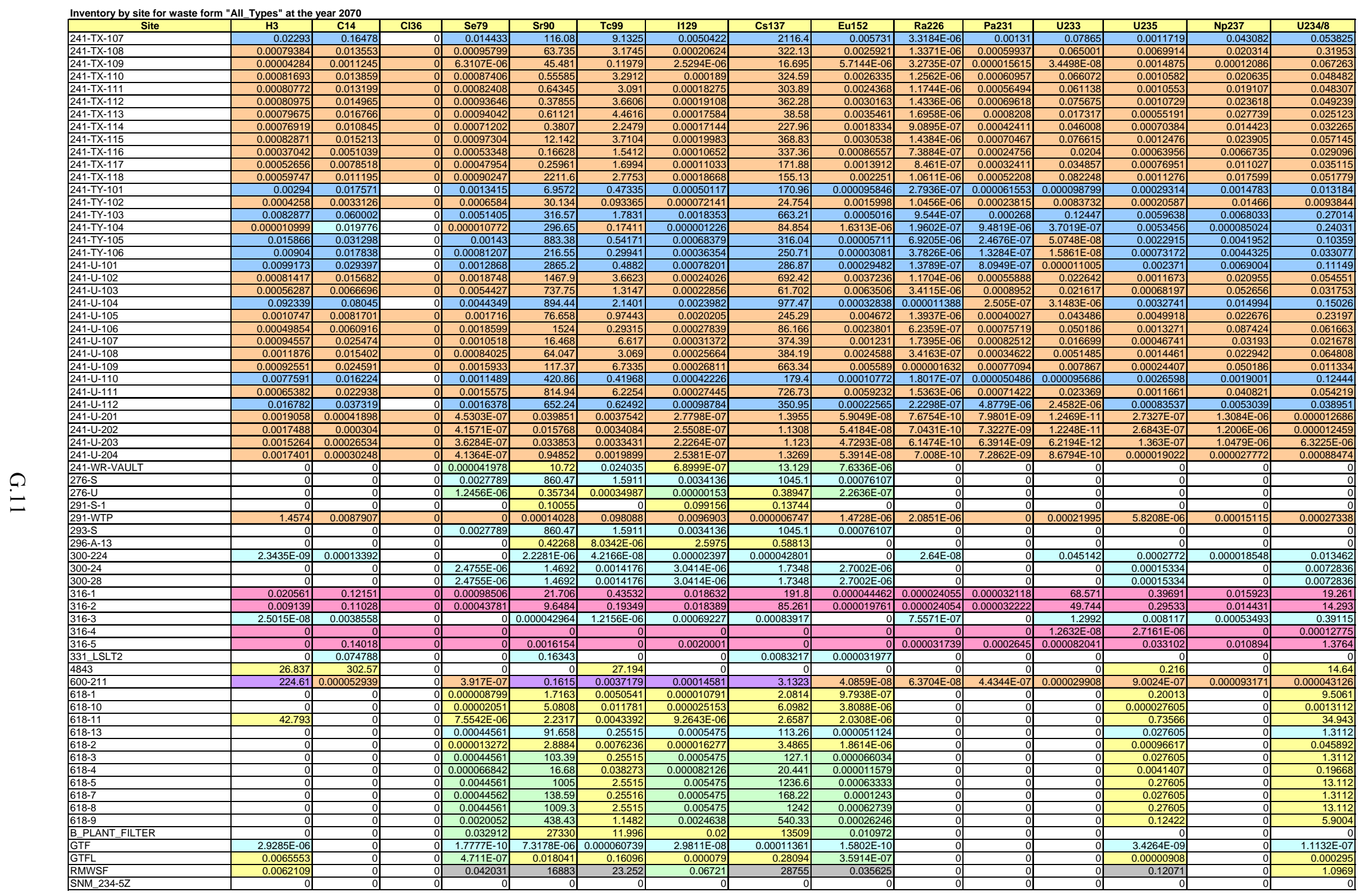


Inventory by site for waste form "All Types" at the year 2070

\begin{tabular}{|c|c|c|c|c|c|c|c|c|c|c|c|c|c|c|c|}
\hline Site & H3 & C14 & $\mathrm{Cl} 36$ & Se79 & Sr90 & Tc99 & 1129 & Cs137 & Eu152 & Ra226 & Pa231 & U233 & U235 & Np237 & U234/8 \\
\hline $\begin{array}{l}\text { UPR-100-F-1 } \\
\end{array}$ & & & & $\frac{0}{468500}$ & \begin{tabular}{|l|}
0.0000003686 \\
\end{tabular} & $\begin{array}{r}0 \\
7139 E_{-07}\end{array}$ & $\begin{array}{r}0 \\
15315 \mathrm{E}-0\end{array}$ & & & & & & $\frac{0}{3695-13}$ & & 0 \\
\hline UPR-100-N-12 & & $\begin{array}{r}0.4233 \\
0\end{array}$ & & & $\begin{array}{l}y^{\prime} \\
0.00038 / 22 \\
\end{array}$ & $\begin{array}{l}7.139 \mathrm{E}-01 \\
0\end{array}$ & & $\frac{0.00055086}{0.049098}$ & $\frac{4.8826-10}{0.00019847}$ & & & & $\frac{3.69 \mathrm{E}-13}{0}$ & & $1.7369 \mathrm{E}-11$ \\
\hline & $2.1733 \mathrm{E}-06$ & & & $2.0783 \mathrm{E}-11$ & 6.6117E-06 & $1.19 \mathrm{E}-08$ & $2.5527 \mathrm{E}-11$ & $\begin{array}{r}0.0 .094090 \\
9.396-06\end{array}$ & & & & & $6.1507 E-15$ & & $\frac{0}{2.8951 \mathrm{E}-13}$ \\
\hline $\begin{array}{l}\text { UPR-100-N-30 } \\
\text { UPR }\end{array}$ & 0.000010272 & $\frac{0_{0}}{2}$ & & $100991 \mathrm{E}-10$ & 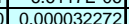 & $=0.9498-08$ & $\frac{1.3764-10}{112764-10}$ & 0.00004591 & $\frac{1.00635-11}{440693-11}$ & & & & $\frac{1.575-14}{3.0753-14}$ & & $\frac{1.546-12}{1.476-12}$ \\
\hline UPR-100-N-35 & & 0.35991 & & & 0 & & & 0.057695 & & & & & & & \\
\hline UPR-100-N-5 & 0.0003304 & 0 & & $3.7405 E-09$ & 0.001107 & $2.1417 \mathrm{E}-06$ & $4.5944 \mathrm{E}-09$ & 0.0015781 & $1.3222 \mathrm{E}-09$ & & & & $1.107 \mathrm{E}-12$ & & $5.2107 \mathrm{E}-11$ \\
\hline UPR-100-N-7 & & & & & & & & & & & & & & & \\
\hline UPR-200-E-1 & 0.0011547 & 0.0019271 & & 0.000041486 & 1.028 & 0.0031237 & $1.5402 E-06$ & & 0.000001195 & $2.9518 \mathrm{E}-07$ & 0.00001886 & & $9.3581 \mathrm{E}-06$ & 0.000070831 & 0.00041835 \\
\hline UPR-200-E-105 & & & & & & 0.017616 & & & & & 0.00005036 & & & & \\
\hline UPR-200-E-107 & $2.2583 \mathrm{E}-06$ & $4.4554 \mathrm{E}-06$ & & $2.0284 E-07$ & 0.0086956 & \begin{tabular}{|l|l|}
0.000070643 \\
\end{tabular} & $9.0615 \mathrm{E}-08$ & 0.04321 & $\begin{array}{l}7.6324 \mathrm{E}-09 \\
\end{array}$ & $9.3824 \mathrm{E}-10$ & $3.1564 \mathrm{E}-1$ & & $8.5783 \mathrm{E}-09$ & $\begin{array}{l}5.6067 \mathrm{E}-07 \\
\end{array}$ & $3.8782 \mathrm{E}-07$ \\
\hline UPR-200-E-108 & 0.00037404 & 0.00031725 & & \begin{tabular}{l|l}
0 & 0.000017678 \\
\end{tabular} & 0.34091 & 0.0085518 & $9.7594 \mathrm{E}-06$ & 3.8993 & $8.6225 E-07$ & 4.4627E-08 & & & & 0.000049152 & \\
\hline \begin{tabular}{|l|} 
UPR-200-E-109- \\
UPR-20-F-110
\end{tabular} & $\frac{0.000067748}{0.0022881}$ & \begin{tabular}{|l}
0.0001337 \\
0.001444
\end{tabular} & & 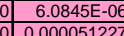 & $\begin{array}{l}0.26084 \\
0^{233996}\end{array}$ & $\begin{array}{l}0.0021197 \\
0003856\end{array}$ & 0.000002719 & 1.2965 & $2.2912 E-07$ & $\begin{array}{l}2.8165 \mathrm{E}-08 \\
1636 \mathrm{E}-07 \\
\end{array}$ & $9.5304 \mathrm{E}-1 \mathrm{C}$ & & $\begin{array}{l}2.5719 E-07 \\
85801506\end{array}$ & 0.000016822 & 0.000011633 \\
\hline UPR-200-E-110 & $\frac{0.0022881}{0.000068159}$ & $\begin{array}{l}0.0015344 \\
0.0063039\end{array}$ & & 0.000051227 & 0.23896 & $\begin{array}{r}0.0038956 \\
0.023846\end{array}$ & $\begin{array}{l}0.000033999 \\
0.000012686\end{array}$ & $\begin{array}{l}1.7555 \\
19156 \\
\end{array}$ & 0.000006221 & $\begin{array}{r}1.6366 \mathrm{E}-07 \\
3.13 \mathrm{E}-09\end{array}$ & $\frac{0.000011138}{4.5542 \mathrm{E}-\mathrm{\varepsilon} \varepsilon}$ & $13064 \mathrm{E}-06$ & $\begin{array}{l}8.5891 \mathrm{E}-06 \\
1446 \mathrm{E}-07\end{array}$ & $\begin{array}{r}0.00000896 \\
0.000098306\end{array}$ & 0.00039409 \\
\hline UPR-200-E-141 & $\frac{0.00000159}{0.00012666}$ & & & & $\frac{0.15166}{0}$ & \begin{tabular}{|r}
0.023840 \\
0.000027694
\end{tabular} & & & & & & $\frac{1.3064 \mathrm{E}-\mathrm{Ct}}{7.0517 \mathrm{E}-11}$ & $\frac{1.4466 \mathrm{E}-0 t}{2.6096 \mathrm{E}-06}$ & & $6.8345 \mathrm{E}-06$ \\
\hline UPR-200-E-145 & 0.0038015 & & & & & 0.00083022 & & & & & & $2.117 \mathrm{E}-0 \mathrm{~S}$ & 0.000078305 & & \\
\hline UPR-200-E-16 & 0.00061515 & 0.00029524 & & $1.2335 \mathrm{E}-07$ & 0.022331 & $\begin{array}{l}0.000053778 \\
\end{array}$ & 0.000052985 & 0.028465 & $1.982 \mathrm{E}-08$ & $1.5742 \mathrm{E}-10$ & $1.6676 \mathrm{E}-0.9$ & & $8.1394 \mathrm{E}-08$ & $3.6082 \mathrm{E}-07$ & \\
\hline & & & & & & & & & & & & & & & $\frac{36 E-06}{58 E-06}$ \\
\hline UPR-200-E-38 & $\frac{0.0078352}{0.072}$ & 0.076872 & & 0.0092206 & 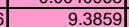 & 2.94 & 0.0017422 & 61.125 & 000062194 & 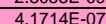 & $\frac{1.5056-06}{6.951-06}$ & 0.00032616 & $\frac{1.7205-16}{9.408 E-06}$ & 0.0055794 & $\frac{.1588 \mathrm{E}-06}{0004584}$ \\
\hline UPR-200-E-39 & & & & 0.000012098 & & & & $\begin{array}{l}0.1 .120 \\
0.19436\end{array}$ & $\frac{3.0436 \mathrm{E}-07}{3.07}$ & & & & & $8.4611 \mathrm{E}-06$ & 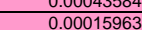 \\
\hline UPR-200-E-40 & 0.00021278 & 0 & & $9.3098 \mathrm{E}-07$ & 0.015969 & \begin{tabular}{|l|}
0.000053401 \\
\end{tabular} & & 0.01495 & $\frac{2.450 \mathrm{E}-1}{2.3409 \mathrm{E}}$ & $3.3271 \mathrm{E}-10$ & $2.4956 \mathrm{E}-0$. & $6.4039 \mathrm{E}-1$ & $3.0242 \mathrm{E}-07$ & $6.5117 \mathrm{E}-07$ & $\frac{0.00015903}{.000012279}$ \\
\hline UPR-200-E-6 & 0.0004577 & 0.00030893 & & 0.000010247 & $\begin{array}{l}0.047786 \\
\end{array}$ & & 0.0000068 & & $1.2442 \mathrm{E}-06$ & & & & $1.7174 \mathrm{E}-06$ & & \\
\hline UPR-200-E-7 & $3.1101 \mathrm{E}-08$ & $5.3087 \mathrm{E}-06$ & & $\begin{array}{l}.4275 \mathrm{E}-07 \\
\end{array}$ & 0.00099919 & $2.7447 \mathrm{E}-06$ & & 0.0012518 & $7.5646 \mathrm{E}-08$ & $8.4893 \mathrm{E}-10$ & $2.1463 \mathrm{E}-07$ & & $6.3671 \mathrm{E}-08$ & $1.5101 \mathrm{E}-06$ & $2.9028 \mathrm{E}-06$ \\
\hline UPR-200-E-73 & 0.00017491 & 0.00014826 & & $8.2633 \mathrm{E}-06$ & 0.15938 & 0.0039971 & $4.5605 E-06$ & 1.8228 & $4.0295 \mathrm{E}-07$ & $2.0859 \mathrm{E}-08$ & & & $4.7775 \mathrm{E}-06$ & 0.000022977 & 0.00021811 \\
\hline UPR-200-E-74 & $8.9035 E-10$ & $8.7602 E-10$ & & $4.2656 \mathrm{E}-11$ & 9.3991E-07 & $1.885 \mathrm{E}-08$ & $1.8793 \mathrm{E}-11$ & $8.3045 E-06$ & $1.9253 \mathrm{E}-12$ & $1.3652 \mathrm{E}-13$ & $1.7938 \mathrm{E}-12$ & & $2.7973 \mathrm{E}-11$ & $1.1627 \mathrm{E}-10$ & $1.2655 \mathrm{E}-09$ \\
\hline UPR-200-E-75 & 0.00045761 & 0.00030891 & & 0.000010246 & 0.047784 & 0.00077904 & $6.7995 E-06$ & 0.35109 & 0.000001244 & $3.2725 \mathrm{E}-08$ & $2.2279 \mathrm{E}-0 \mathrm{OC}$ & & $1.7179 \mathrm{E}-06$ & 0.000017919 & 0.000078825 \\
\hline UPR-200-E-77 & 7.8428E-06 & 0.000010637 & & 4.9241E-07 & 0.015934 & 0.00023815 & 1.0541E-07 & 0.096723 & $6.4131 \mathrm{E}-09$ & 2.0862E- -09 & & & 4.8874E- -07 & $1.3435 \mathrm{E}-06$ & 0.000021845 \\
\hline UPR-200-E-78 & 9.8185E-07| & 0.000021635 & & $2.6928 \mathrm{E}-06$ & & 0.00084319 & $5.0429 E-08$ & 0.67339 & 0.000016991 & & $6.8334 \mathrm{E}-1 \mathrm{C}$ & & $6.7314 \mathrm{E}-08$ & 3.5637E-06 & 3.1806 E-06 \\
\hline UPR-200-E-79 & 0.00035402 & 0.0010565 & & 0.000041894 & 1.6314 & 0.012494 & 0.000017488 & 7.3451 & $1.8055 E-06$ & $2.0075 \mathrm{E}-07$ & $2.7971 \mathrm{E}-06$ & & $1.7366 \mathrm{E}-06$ & 0.00010805 & 0.000079067 \\
\hline UPR-200-E-80 & 0.000024463 & $\begin{array}{r}0.000032637 \\
011485\end{array}$ & & $\begin{array}{l}1.4928 \mathrm{E}-06 \\
0.0002592\end{array}$ & & 0.00073013 & $3.1909 \mathrm{E}-07$ & 0.29756 & $\begin{array}{r}1.97 \mathrm{E}-08 \\
0.001982\end{array}$ & $\begin{array}{l}6.4233 \mathrm{E}-09 \\
305095-07\end{array}$ & C & 0.01130 & $\frac{1.4916 E-06}{0.00061127}$ & $\begin{array}{r}4.1267 E-06 \\
00001238\end{array}$ & 0.000067167 \\
\hline UPR-200-E-82 & $\begin{array}{l}0.4400 \\
0.0037735 \\
\end{array}$ & 0.14405 & & $\frac{0.00000594}{0.0044368}$ & $\begin{array}{l}1.0 .04 \\
4.5157\end{array}$ & $\frac{0.0745}{14159}$ & 0.05304 & 29.149 & - & 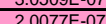 & $\frac{.00024016}{3.348 \mathrm{~F}-6}$ & 0 & $\frac{0.0000151}{45250-06}$ & 0.00000250 & 0.0029785 \\
\hline UPR-200-E-84 & $\begin{array}{l}.0013094 \\
0.001\end{array}$ & $3.004 \mathrm{E}-08$ & & $\begin{array}{l}0.0044368 \\
3.8511 \mathrm{E}-09 \\
\end{array}$ & \begin{tabular}{|l|l|}
0.000022192 \\
\end{tabular} & \begin{tabular}{|r}
1.459 \\
0.000001208
\end{tabular} & $\begin{array}{l}0.00085909 \\
3.7958 \mathrm{E}-06\end{array}$ & $\begin{array}{r}29.459 \\
9.1125 \mathrm{E}-06\end{array}$ & $\frac{0.000299844}{4.91415-10}$ & $\frac{2.07 / \mathrm{E}-\mathrm{U} / 1}{2.3041 \mathrm{E}-10}$ & $\frac{3.3498 \mathrm{E}-0 \mathrm{C}}{1.4938 \mathrm{E}-0 \mathrm{C}}$ & & $1.0881 \mathrm{E}-08$ & $\begin{array}{r}0.00461 \\
5.1668 \mathrm{E}-06\end{array}$ & $\frac{0.00020991}{551446-07}$ \\
\hline UPR-200-E-85 & 0.00095011 & 0.0093168 & & 0.0011172 & & & 0.00021125 & 7.4114 & 0.000075388 & & 8 & 0.000039573 & 1.1389E-06 & $\frac{1.501618}{0.001618}$ & $\begin{array}{r}5.1 .146 \\
0.0005 \\
\end{array}$ \\
\hline $200-E-86$ & 0.0001011 & 0.01207 & & 0.15702 & & 0.03045 & 0.00002612 & 30431 & . & $6.05606 \mathrm{E}, 07$ & & & & & 0052844 \\
\hline UPR-200-E-87 & 8.9556-11 & 0.0000110178 & & $4.585 \mathrm{E}-07$ & 0.00030545 & $9.28435-07$ & $\frac{0.10025-10}{4.1092-10}$ & 0.00037693 & $\frac{1.068 \mathrm{E}-07}{1.067}$ & $\frac{.0 .595-09}{3.269-09}$ & $\frac{0.00116 \mathrm{E}-06}{3.016}$ & & $\frac{0.090535-09}{7.9835}$ & 0.000011123 & $\frac{0.0014069}{1.8007 \mathrm{E}-07}$ \\
\hline & & $\frac{0.0098035}{0.098}$ & & 0.00044622 & $\mid$\begin{tabular}{|r|}
19.127 \\
\end{tabular} & & 0.00019938 & 95.082 & 0.000016794 & $\frac{2.0644 \mathrm{E}-06}{2.06}$ & $\frac{7.0669 E-0 \varepsilon}{7}$ & & (18859 & 0.0012335 & $\frac{1.8007-07}{0.00085309}$ \\
\hline UPR-200-W-100 & 0.0011443 & 0.00077239 & & 0.000025619 & 0.11947 & 0.0019475 & 0.000016997 & 0.8776 & $3.1094 E-06$ & $8.1805 E-08$ & 0.000005571 & & $4.2933 \mathrm{E}-06$ & 0.000044801 & $\begin{array}{l}0.000601909 \\
0.00019707\end{array}$ \\
\hline UPR-200-W-101 & & & & & & & & & & & & $1.5261 \mathrm{E}-0$ & & & 0.0025787 \\
\hline $200-W-102$ & 7.7349E-09 & 0.000016288 & & $7.4472 E-07$ & 0.00054891 & $1.5083 \mathrm{E}-06$ & & 0.00068763 & $6.7257 \mathrm{E}-07$ & $2.6049 \mathrm{E}-09$ & $2.6207 \mathrm{E}-0 \mathrm{G}$ & & $7.7476 \mathrm{E}-09$ & 0.000018407 & $1.7864 \mathrm{E}-07$ \\
\hline UPR-200-W-103 & & & & & 0 & & & & & & $4.6394 \mathrm{E}-14$ & & $5.389 \mathrm{E}-12$ & 0.0038474 & $1.0954 \mathrm{E}-10$ \\
\hline UPR-200-W-12 & 0.00000174 & $5.1933 E-06$ & & $2.0593 \mathrm{E}-07$ & 0.0080214 & \begin{tabular}{|l|}
0.000061394 \\
\end{tabular} & $8.5986 \mathrm{E}-08$ & 0.03611 & $8.8684 \mathrm{E}-0 \mathrm{C}$ & $9.8696 \mathrm{E}-10$ & $1.3752 \mathrm{E}-0 \varepsilon$ & & & 5.3114 & $3.8876 \mathrm{E}-07$ \\
\hline UPR-200-W-127 & 0.00018712 & & & & 1.1054E-11 & & & $2.917 \mathrm{E}-11$ & & & & & 1.80 & 1.2322 & $8.0002 E-11$ \\
\hline UPR-200-W-130 & ${ }^{2}$ & 0 & & $3.0701 E-13$ & 2.6341E-11 & 1.764E-11 & 0 & $3.1178 E-11$ & 9.4995E-15 & 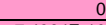 & 1.8829E-15 & & $2.2145 \mathrm{E}-11$ & $3.445 \mathrm{~s}$ & $8.9735 \mathrm{E}-10$ \\
\hline & $1.8043 E-06$ & $3.5609 \mathrm{E}-06$ & & 1.6203E-07 & & & $7.2388 \mathrm{E}-08$ & & & 7..4964E-10 & $2.5366 \mathrm{E}-1$. & & & & 3 3E-07 \\
\hline UPR-200-W-132 & & 0.00080882 & & 0.000045062 & 0.86907 & 0.02180 & 0.000024875 & 9.9433 & 0.000002198 & $1.1376 \mathrm{E}-07$ & & & & 0.00012533 & 0.0011897 \\
\hline & 0.001908 & 0.0016172 & & 0.000090141 & 1.7382 & $\begin{array}{l}0.043596 \\
0.01416\end{array}$ & 0.000049755 & 19.883 & 4.3962E-06 & $2.2753 \mathrm{E}-07$ & & $50385 E_{-0} \mathrm{c}$ & 0.000052103 & 0.0002 & 0.0023791 \\
\hline UPR-200-W-1630 & 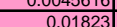 & 5413 & & $270095-11$ & $50002=07$ & 0.000272517 & 25866 & & & $28749 F_{-12}$ & $47286 \mathrm{E}-12^{2}$ & S. & & & \\
\hline UPR-200-W-19 & $\begin{array}{l}0.01020 \\
4.0867 E-10\end{array}$ & $\frac{1.450-10}{8034-10}$ & & $\begin{array}{l}\text {..1909-11 } \\
.6698 \mathrm{E}-11\end{array}$ & | & 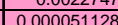 & 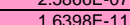 & 2.4035- & & $\frac{1.0695-12}{7693-09}$ & $\frac{1.1700-10}{12107-10}$ & 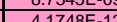 & & & $\begin{array}{r}0.014416 \\
9.5442-06\end{array}$ \\
\hline UPR-200-W-2 & 年. 0.0027799 & $\frac{0.0037698}{0.007698}$ & & $\frac{0.001745}{0.0001745}$ & 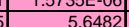 & $\mid 0.084417$ & $\frac{1.000037367}{0.00037}$ & & $\frac{1.5731-16}{2.2731-06}$ & $\frac{1.59425-07}{7.3942 E}$ & & & & & $\frac{1.54446-00}{0.07432}$ \\
\hline UPR-200-W-20 & 0.00043651 & & & & 2 25793E-11 & & & $6.8061 \mathrm{E}-11$ & & & & & & & $1.8382 \mathrm{E}-1 \mathrm{c}$ \\
\hline UPR-200-W-21 & 0 & 00047384 & & 80026404 & | & 0127 & & & & 66666 & & & & & $1.838<E-10$ \\
\hline UPF & 0.000031063 & 0.000042121 & & $\begin{array}{l}1.9505 E-06 \\
1.956\end{array}$ & 0.063126 & 0.00094328 & & 0.383 & & & & & & 532 & 0.00 \\
\hline UPR-200-W-28 & 0.00027566 & 000054387 & & 0.00002476 & $\frac{10613}{10613}$ & 0.0086221 & 0.000011063 & 5276 & $93215 \mathrm{E}-07$ & $114575-07$ & $38988 \mathrm{E}-0 \mathrm{c}$ & & & 8444 & 0004332 \\
\hline $200-10-29$ & 0.00044988 & 0.00030371 & & 0.000010073 & 0.046984 & 0. & $6.6849 \mathrm{E}-06$ & 0.34519 & 0.0000 & $3.2171 \mathrm{E}-08$ & $2.1903 E-06$ & & & 0.000017614 & \\
\hline UPR-200-W-3 & 0.0001 & & & & & \begin{tabular}{|l|l|}
$0.00001554 !$ \\
\end{tabular} & & & & & & $1.1189 \mathrm{E}-1 \mathrm{C}$ & & & 0.00018901 \\
\hline UPR-200-W-33 & \begin{tabular}{ll|l}
$1.1644 \mathrm{E}-06$ \\
\end{tabular} & $9.8721 \mathrm{E}-07$ & & $5.5006 \mathrm{E}-08$ & \begin{tabular}{l|l}
0.0010608 \\
\end{tabular} & 0.0000 & $3.0359 \mathrm{E}-08$ & 0.012 & 2.682 & $1.388 \mathrm{C}$ & & & & & $1.4521 E-06$ \\
\hline UPR-200- & 0.00 & 0.0032902 & & 0.00018335 & 3.5363 & 0.088694 & 0.0001012 & 40.454 & $8.9408 \mathrm{E}-06$ & $4.6289 \mathrm{E}-07$ & & & 0.0001 & & \\
\hline UPR-200-W-39 & 0.00011812 & 0 & & & & 0.000011427 & & & & & & $1.3045 \mathrm{E}-\mathrm{T}$ & 4.828 & & 0.0002204 \\
\hline & 0.00042089 & 0.0011683 & & 0.000054613 & & & 0.000033149 & $1.66 \mathrm{r}$ & & & $1.9677 \mathrm{E}-08$ & & 3923E-07 & 0.00015075 & \\
\hline & & & & $0_{0}$ & 0 & & 0 & & ( & & & & & & 3.451E-14 \\
\hline UPR-200-W-8 & & 0 & & $6.0303 \mathrm{E}-08$ & $0.0124 / 5$ & 0.000034526 & 7.4072E-08 & 0.015322 & $6.9134 \mathrm{E}-09$ & & & & & & \\
\hline UPR-200-W-82 & $\frac{0.00087309}{6.7755 E-10}$ & $\begin{array}{r}0 \\
5.7595 E-10\end{array}$ & & $\begin{array}{r}0 \\
4.056 \mathrm{E}-11 \\
\end{array}$ & 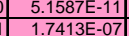 & \begin{tabular}{|r}
0 \\
$1.5284 \mathrm{E}-08$ \\
\end{tabular} & $\frac{0}{2.4003 E-11}$ & $\frac{1.3612 \mathrm{E}-10}{9.597 \mathrm{E}-06}$ & $4.2965 \mathrm{E}-12$ & $\frac{0}{2.4051 E-15}$ & $\frac{1.5518 \mathrm{E}-12}{2}$ & & $\frac{8.4057-12}{1.9687 \mathrm{E}-13}$ & $\frac{5.75 \mathrm{E}-09}{6.98911}$ & $\frac{3.73396-10}{9.08 E-12}$ \\
\hline
\end{tabular}




\begin{tabular}{|c|c|c|c|c|c|c|c|c|c|c|c|c|c|c|c|}
\hline $\begin{array}{r}\text { Site } \\
\end{array}$ & & & $\mathrm{Cl}_{36} \mathrm{~F}$ & & & & & & & & & U233 & & & \\
\hline \begin{tabular}{|l|} 
UPR-200-W-95 \\
\end{tabular} & & 0.000059287 & & $2.7689 \mathrm{E}-06$ & 0.018209 & 0.0010505 & $1.6825 \mathrm{E}-06$ & 0.59202 & $3.2775 \mathrm{E}-07$ & $1.5419 \mathrm{E}-10$ & $9.9351 \mathrm{E}-10$ & & $1.7231 \mathrm{E}-08$ & $7.6532 \mathrm{E}-06$ & $8.0998 \mathrm{E}-07$ \\
\hline \begin{tabular}{|l} 
UPR-200-W-96 \\
\end{tabular} & $2.8806 \mathrm{E}-09$ & \begin{tabular}{|l|}
$2.4476 \mathrm{E}-09$ \\
\end{tabular} & & $1.7243 \mathrm{E}-10$ & & $6.4953 \mathrm{E}-08$ & $1.0202 \mathrm{E}-10$ & & $1.8256 \mathrm{E}-11$ & & & & $8.3652 \mathrm{E}-13$ & $2.9716 \mathrm{E}-10$ & $3.8604 \mathrm{E}-11$ \\
\hline \begin{tabular}{|l} 
UPR-200-W-97 \\
\end{tabular} & & & & & 0.0034611 & & & 0.0043361 & $2.1563 \mathrm{E}-07$ & $2.7838 \mathrm{E}-09$ & $5.5958 \mathrm{E}-07$ & & $2.2253 \mathrm{E}-07$ & $3.9389 E-06$ & 0.000010151 \\
\hline \begin{tabular}{|l|} 
UPR-200-W-98 \\
\end{tabular} & 0.000074597 & \begin{tabular}{|l}
0.00010116 \\
\end{tabular} & & $4.6829 \mathrm{E}-06$ & 0.15159 & 0.0022651 & $1.0027 \mathrm{E}-06$ & 0.91988 & & $1.9838 \mathrm{E}-08$ & & & $4.6484 \mathrm{E}-06$ & 0.000012781 & \\
\hline \begin{tabular}{|l|} 
UPR-300-1 \\
\end{tabular} & & & & $\begin{array}{l}2.4757 \mathrm{E}-06 \\
.1757-09 \\
\end{array}$ & 0.87815 & 0.0014175 & 0.000003041 & 0.97475 & $7.506 \mathrm{E}-07$ & & 0 & & & & \\
\hline $\begin{array}{ll}\text { UPR-300-2 } \\
\text { LS 50-2 }\end{array}$ & & & & $2.4757 \mathrm{E}-09$ & 0.00056049 & $1.4175 \mathrm{E}-06$ & $3.041 \mathrm{E}-09$ & 0.00068981 & $3.4831 E-10$ & & $\frac{0}{10}$ & & & & \\
\hline \begin{tabular}{|l} 
US Ecology \\
\end{tabular} & 15869 & 5040.7 & 3.228 & $\begin{array}{r}0 \\
0001877 \\
\end{array}$ & & & & 16268 & 32.858 & 313.24 & 0.001316 & & 30.576 & & 1789.1 \\
\hline \begin{tabular}{|l|} 
WIIP_118-KE-1 \\
WIPP 118-KW-1
\end{tabular} & & & & \begin{tabular}{|c|}
0.0015877 \\
0.0012838 \\
\end{tabular} & $\begin{array}{l}3619.6 \\
29129\end{array}$ & 53.787 & $\begin{array}{l}0.0019471 \\
0.001544 \\
\end{array}$ & $\begin{array}{r}3884.6 \\
3411\end{array}$ & 0.076994 & & & & 0.087495 & $\begin{array}{r}0.154 \\
0.072598 \\
\end{array}$ & $\frac{4.1185}{2.123}$ \\
\hline WIPP $218-\mathrm{E}-12 \mathrm{~B}$ & & & & $\begin{aligned} 0.0012838 \\
0\end{aligned}$ & $\begin{array}{r}2912.9 \\
0.56182 \\
\end{array}$ & $\begin{array}{r}4.339 \\
0.00093028\end{array}$ & $0.0015 / 44$ & $\begin{array}{r}3141.1 \\
0.66488 \\
\end{array}$ & $\begin{array}{r}0.019284 \\
5.4689 \mathrm{E}-07 \\
\end{array}$ & & & & 0.053415 & 0.072598 & 2.5143 \\
\hline WIPP $218-W-3 A$ & 0.044225 & 1.5828 & & & 1.0532 & 0.001657 & & 1.9273 & 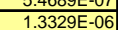 & & & 0.2405 & 0.086239 & & $\begin{array}{r}0 \\
4.418\end{array}$ \\
\hline WIPP_218-W-3AE & & & & 0.000018564 & 4518.7 & 0.66685 & & 9262 & 0.010364 & & & 1.1197E-08 & 0.0000166 & & $\begin{array}{r}0.000682 \\
0.418\end{array}$ \\
\hline WIPP_218-W-4B & & & & 0 & 1131.6 & & & 1342.6 & & & & & & & $\frac{0.000682}{0.52425}$ \\
\hline WIPP $=218-W-4 C$ & & 0 & & 0 & $\begin{array}{l}9119.5 \\
\end{array}$ & 14.787 & & 10936 & 0.009164 & & & $\frac{7.566}{7.566}>20$ & $\frac{0.23}{0.23}+2$ & 0.098767 & $\frac{0.52425}{1.2337}$ \\
\hline WIPP $234-5 \mathrm{Z}$ & & 0 & & $\overrightarrow{0}$ & 0 & & & 0 & & & & & & & \\
\hline WIPP 241-Z-361 & & & & 0 & & & & & & & & & & & \\
\hline WIPP_H2-CHTRU-PKGS & 0.0234 & 0.07183 & & 0.0014422 & 2439.6 & 18.139 & 0.00013282 & 109.74 & 0.00014821 & $6.9276 \mathrm{E}-06$ & 0.00063087 & 0.00000306 & 0.1274 & 0.056378 & 5.9562 \\
\hline WIPP H2-RHTRU-PKG & 0.04312 & 1.0498 & & 0.079062 & 133460 & 156.14 & 0.063167 & & 2.9655 & 0.0002658 & 0.90071 & 2.59 & 0.68042 & 2.3887 & 30.386 \\
\hline WIPP_RMWSF & 0.001146 & 0.000092136 & & 0.0013182 & 5027.5 & & 0.0021613 & 6364.9 & 0.0034567 & & & 0.087283 & 0.071953 & 0.20743 & 3.6867 \\
\hline Yucca_100-K-42 & 318.57 & 343.53 & & 43.097 & 891920 & 1439.7 & 3.185 & 1255300 & 11.855 & & & & 14.493 & 28.599 & 828.06 \\
\hline Yucca_100-K-43 & 318.57 & 343.53 & & 43.097 & 891920 & 1439.7 & 3.185 & 1255300 & 11.855 & & & & $14.493^{2}$ & & 828.06 \\
\hline $218-W-3 A$ & 0.32914 & 55.321 & & 0.010074 & 5410.7 & 5.6327 & 0.011167 & 6291 & & & & & 0.069017 & & 0.028486 \\
\hline $\begin{array}{l}\text { Yucca_218-W-4C } \\
\end{array}$ & 0.70216 & 11.203 & & 0.021491 & 4550.7 & 12.855 & 0.023823 & & 0.01814 & & & & & 0.40 & 0.035317 \\
\hline $\begin{array}{l}\text { Yucca_221-T-11-R } \\
\text { Yuch }\end{array}$ & 0.2135 & 103.93 & & 2.7675 & $\frac{456.39}{2750}+2$ & 0.705 & 0.001398 & 976.36 & 2.118 & & & 6.9493 & & & 12.35 \\
\hline \begin{tabular}{|l} 
Yucca_225-B \\
Yucca 4843
\end{tabular} & $21200+3$ & $\frac{0}{12619}$ & & $\begin{array}{r}0 \\
070805 \\
-12\end{array}$ & 3795900 & & & $\frac{9375600}{7201070}-20$ & & & & & & & 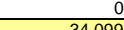 \\
\hline $\begin{array}{l}\text { Yuuca a } 4843 \\
\text { YUCCA H2-HLW-CANISTER }\end{array}$ & & & & $\begin{array}{ll}0.99805 \\
2.747 \\
\end{array}$ & $\frac{\angle 48650}{8006400}$ & 3677.4 & $\frac{0.5518}{2.1918}$ & 8965800 & $\frac{0.60412}{40.587}$ & 0.010386 & 3.1086 & 692.76 & $\frac{0.9105}{7.9052}$ & $\begin{array}{ll}32.020 \\
78.025 \\
\end{array}$ & $\begin{array}{ll}34.099 \\
368.62\end{array}$ \\
\hline YUCCA_RMWSF & & 0 & & & 490510 & & & 732330 & & & & & & & 0 \\
\hline \begin{tabular}{|l|l|l|l} 
All_Sites \\
\end{tabular} & 27502 & 56324 & 348.38 & 184.87 & 15375000 & 31321 & 65.513 & 22977000 & 122.88 & 718.74 & 6.1599 & 954.41 & 109.6 & 273.66 & 5629.5 \\
\hline \begin{tabular}{|l|} 
Nonzero sites \\
\end{tabular} & 547 & 545 & & 528 & 671 & 562 & 529 & 633 & 598 & 412 & 423 & 352 & 602 & 523 & 626 \\
\hline
\end{tabular}




\section{Distribution}

(Distribution is by electronic copy.)

No. of

Copies

3 DOE Office of River Protection

M.E. Burandt

H6-60

R. W. Lober

S.A. Wiegman

6 DOE Richland Operations Office

B. L. Charboneau

A6-33

B. L. Foley

R. D. Hildebrand

J. G. Morse

K. M. Thompson

DOE Public Reading Room

5 CH2M HILL Hanford Group, Inc.

M. Connelly

H6-03

J. G. Field

J. G. Kristofzski

F. M. Mann

W. J. McMahon

3 Washington Closure

K. R. Fecht

H4-21

E. T. Feist

S. G. Weiss

2 Fluor Federal Services

R. Khaleel

R. J. Puigh

E6-17

E6-17

6 Fluor Hanford, Inc.

B. A. Austin

J. V. Borghese

L. R. Fitch

B. H. Ford

T. W. Fogwell

J. Hoover
No. of

Copies

47 Pacific Northwest National Laboratory

R. L. Aaberg K3-54

M. P. Bergeron K9-36

B. N. Bjornstad K6-81

C. A. Brandt K9-04

R. W. Bryce (5) E6-35

A. L. Bunn K6-85

K. J. Cantrell K6-81

D. W. Engel K5-12

P. W. Eslinger K6-04

J. C. Evans, Jr. K6-96

M. J. Fayer K9-33

E. J. Freeman K9-36

V.L. Freedman K9-36

M. D. Freshley K9-33

G. W. Gee K9-33

T. J. Gilmore K6-96

D. G. Horton K6-81

C. T. Kincaid K9-33

G. V. Last (5) K6-81

C. A. LoPresti K5-12

B. A. Napier K3-54

W. J. Martin K6-81

T. B. Miley K6-04

C. J. Murray K6-81

I. C. Nelson K3-54

W. E. Nichols K9-33

B.E. Opitz K6-75

G. W. Patton K6-75

C. L. Rakowski K9-33

J. V. Ramsdell, Jr K3-54

R. G. Riley K6-96

M. L. Rockhold K9-36

P. A. Scott K9-46

R. J. Serne P7-22

D. L. Strenge K3-54

P. D. Thorne K9-33

M. D. Williams K6-96

S. K. Wurstner K9-36

Hanford Technical Library $\quad$ H2-53 